\title{
Jauno vēsturnieku zinātniskie lasījumi
}

$6 / 2020$ 

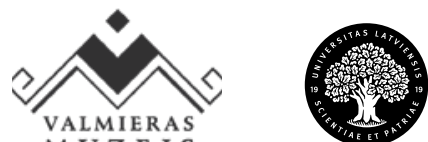

LATVIJAS UNIVERSITĀTE LATVIJAS VĒSTURES

INSTITŪTS

MUZE J S 

VALMIERAS PILSĒTAS PAŠVALDĪBAS VALMIERAS MUZEJS LATVIJAS UNIVERSITĀTES LATVIJAS VËSTURES INSTITÜTS

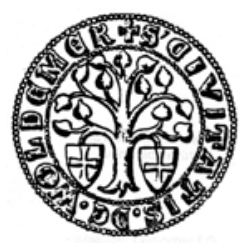

\section{Jauno vēsturnieku zinātniskie lasījumi VI}

Starpdisciplināri pētījumi Latvijas vēsturē

\section{The Scholarly Readings of Young Historians VI}


Jauno vēsturnieku zinātniskie lasijjumi VI $=$ The Scholarly Readings of Young Historians VI. Zinātniskā redaktore Kristīne Beķere. Rīga: LU Akadēmiskais apgāds, 2021. 180 lpp.

Izdevumā "Jauno vēsturnieku zinātniskie lasījumi VI" publicēti 11 raksti, kuru pamatā ir referātu materiāli, kas nolasìti 2020. gada 27. un 28. novembrī Valmieras muzeja un Latvijas Universitātes Latvijas vēstures institūta interneta vidē rīkotajā konferencē "Jauno vēsturnieku zinātniskie lasījumi". Krājumu izdod Latvijas Universitātes Latvijas vēstures institūts sadarbībā ar Valmieras pilsētas pašvaldības Valmieras muzeju.

Krājuma sagatavošanu un izdošanu finansē Izglìtības un zinātnes ministrijas finansētā Valsts pētijumu programma "Latvijas mantojums un nākotnes izaicinājumi valsts ilgtspējai", projekts "Indivīda, sabiedrības un valsts mijiedarbība kopējā Latvijas vēstures procesā: vērtību konflikti un kopīgu vērtību veidošanās vēsturiskos lūzumu punktos", projekta Nr. VPP-IZM-2018/1-0018.

Visi raksti ir anonīmi recenzēti. Recenzenti: nozares speciālisti no Latvijas Universitātes Latvijas vēstures institūta, Vēstures un filozofijas fakultātes, Filozofijas un sociolog̣ijas institūta, Latvijas Nacionālā arhīva, Daugavpils Universitātes, Latvijas Kara muzeja un Latvijas Nacionālās bibliotēkas.

Krājuma sastādītāji: Kristīne Beķere, Alberts Rokpelnis Zinātniskā redkolēgija: $P h D$ Kristīne Beḳere, LU Latvijas vēstures institūts; Dr. hist. Ilze Boldāne-Zeḷenkova, LU Latvijas vēstures institūts, Dr. hist. Anita Čerpinska, Latvijas Nacionālais arhīvs; Dr. hist. Eva Eihmane, LU Latvijas vēstures institūts; $P h D$ Mati Laur, University of Tartu; $P h D$ Laurynas Kurila, Lithuanian Institute of History; $D r$. hist. Uldis Neiburgs, LU Latvijas vēstures institūts; $P h D$ Rasa Račiūnaitè-Paužuolienė, Vytautas Magnus University; Mg. hist. Alberts Rokpelnis, Valmieras muzejs; Dr. hist. Guntis Zemītis, LU Latvijas vēstures institūts.

Literārās redaktores: Andra Damberga (angḷu valoda), Agita Kazakeviča (latviešu valoda)

Maketētāja Žanna Kresso

Vāka dizains Baiba Lazdiṇa (LU Akadēmiskais apgāds)

(C) Latvijas Universitāte, 2021

(C) Rakstu autori, 2021

(C) Valmieras muzejs, 2021

(C) LU Latvijas vēstures institūts, 2021

https://doi.org/10.22364/jvzl.06

ISBN 978-9934-18-637-0

ISBN 978-9934-18-638-7 (PDF) 


\section{SATURS / CONTENTS}

PRIEKŠVĀRDS $\ldots \ldots \ldots \ldots \ldots \ldots \ldots \ldots \ldots \ldots \ldots \ldots \ldots \ldots \ldots \ldots \ldots \ldots$

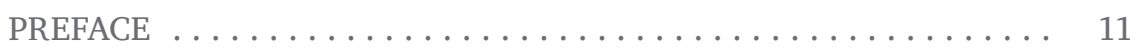

\section{Justine Fišere}

Rīgas Mazās giildes cunftu pārkāpumu un sodu antropolog̣ija,

14. gadsimta otrā puse - 17. gadsimta sākums: šrāgu tekstu piemērs . . . 15

Anthropology of Misconduct and Punishment of Riga Artisans

of the Small Guild, Second Half of $14^{\text {th }}$ Century - Beginning

of $17^{\text {th }}$ Century: Example of Statutes of Artisans $\ldots \ldots \ldots 26$

\section{Aleksandrs Petrovs}

Padomju Latvijas rūpniecības atjaunošana un attīstība 20. gadsimta

40.-50. gados: būvmateriālu ražošanas nozares piemērs

Industrial Recovery and Development of Soviet Latvia in

the 1940s-1950s: The Example of Building Materials

Production Sector

\section{Guna Plakane}

Latvijas Komunistiskās partijas satelītorganizācijas 20. gadsimta

20. gados: Rīgas Arodbiedrību centrālbiroja piemērs

Satellite Organizations of the Latvian Communist Party in

the 1920s: Example of Riga Trade Union Central Bureau

\section{Karina Račaitìte (Karina Račaitytè)}

Identity of Kaunas Inhabitants: Memories of Three Generations . . . 58

Kauñas identitāte: trīs paaudžu atmiņas . . . . . . . . . . . . . . 69

\section{Reinis Ratnieks}

Nacionālo partizānu cīṇas Valmieras apriņ̧̧ī (1944-1953):

atspoguḷojums Latvijas PSR literatūrā

National Partisan Struggles in Valmiera District (1944-1953):

Representation in Literature of the Latvian SSR 


\section{Margarita Novikova}

Agreement on the Matters of Religion Concluded During

the Assembly of Territorial Estates in Pernau (1552) in Context

of the Dispute of Riga (1549-1554) . . . . . . . . . . . . . . 85

Pērnavas 1552. gada kārtu sapulces recesa lēmums reliǵijas

jautājumā Rīgas arhibīskapijas kārtu politikas kontekstā . . . . . . . . . 103

\section{Gints Skutāns}

Beverīnas meklējumu atrisinājums . . . . . . . . . . . . . . . . 105

Solution to the Problem of Search for Beverīna Castle . . . . . . . . . . 120

\section{Anastasija Smirnova}

Spread of Information About Urban Elberfeld Social Care

System in Riga (Late $19^{\text {th }}-$ Early $20^{\text {th }}$ Century) . . . . . . . . . . . 122

Informācijas izplatīšanās par Elberfeldes urbāno sociālās aprūpes

sistēmu Rīgā (19. gadsimta beigas - 20. gadsimta sākums) . . . . . . 135

\section{Kaspars Strods}

Sarežǵītais pagātnes mantojums Latvijā: ieskats Otrā pasaules

kara piemiṇas vietās Rēzeknē (1945-1991) . . . . . . . . . . . . . . . . 137

Difficult Heritage of Latvia: Insight Into the Memorial

Places of World War II in Rēzekne (1945-1991) . . . . . . . . . . . . . 151

\section{Ëvalds Vilkončus (Evaldas Vilkončius)}

Evolution of Public Hospital Architecture During

the Interwar Lithuania . . . . . . . . . . . . . . . . . . 153

Slimnīcu arhitektūiras attīstība starpkaru Lietuvā . . . . . . . . . . . . 165

\section{Mikus Žagata}

Zviedru karaspēka apgāde Vidzemē 1700. gada nogalē un 1701. gada pirmajā pusē . . . . . . . . . . . . . . . . 166

Provision of Swedish Army in Livland at the End of 1700

and the First Half of 1701

\section{Pielikums / Appendix}

Tiešsaistes konferences

“Jauno vēsturnieku Zinātniskie lasījumi VI” programma . . . . . . . . 176

Programme of the Online Conference "The Scholarly 


\section{PRIEKŠVĀRDS}

Jauno vēsturnieku zinātniskie lasijjumi nu jau ir izveidojušies par stabilu ikgadēju tradīciju Latvijas zinātnes dzīvē, tāpat kā lasījumiem sekojošais rakstu krājums. 2020. gada pavasarī konferences organizētāji, uzsākot gatavošanos jau sestajiem Jauno vēsturnieku lasijumiem, lēma, ka ir pienācis laiks šo Latvijā jau labi nostiprinājušos tradīciju paplašināt un pacelt jaunā līmenī, rīkojot lasījumus starptautiskus. Iesākumam - Baltijas valstu mērogā.

Konferences rīkošanu un šì krājuma sagatavošanu un izdošanu finansiāli atbalsta Izglìtības un zinātnes ministrijas finansētā Valsts pētijumu programma "Latvijas mantojums un nākotnes izaicinājumi valsts ilgtspējai", projekts "Indivīda, sabiedrības un valsts mijiedarbība kopējā Latvijas vēstures procesā: vērtību konflikti un kopīgu vērtību veidošanās vēsturiskos lūzumu punktos" (projekta Nr. VPP-IZM-2018/1-0018).

Jauno vēsturnieku VI lasījumu rīkošana bija saistìta ar vairākiem sarežgịjumiem. Zināms izaicinājums bija ar lasījumu tradīciju iepazīstināt lietuviešu un igauņu kolēǵus. Esam pateicīgi un priecīgi par kaimiņvalstu jauno vēsturnieku izrādīto interesi. Tomēr neapšaubāmi vislielākais izaicinājums konferences rīkošanā bija COVID-19 pandēmija un ar to saistītie pulcēšanās ierobežojumi. Pavasarī, kad parasti vienmēr tikuši izsludināti lasījumi, situācija bija nedroša, neziņas pilna un visnotal neskaidra. Tagad, pēc gada, kad ir pieejama vakcīna un jau faktiski esam pieraduši, ka jebkurš pasākums pilnīgi noteikti un droši varēs notikt attālināti, jaunā situācija jau ir kḷuvusi ierasta. Pandēmijas iegrožošanai nepieciešamie ierobežojumi ir kḷuvuši par faktoru, ar kuru rēķināmies - it kā neprognozējamu faktoru, bet tomēr lielā mērā paredzamu. Vairākums zinātnē un augstākajā izglìtībā iesaistīto esam jau arī pieraduši strādāt virtuālajā vidē, satikties "Zoom" vai "MS Teams" programmā. Daudzreiz tā tiešām ir arī ērtāk un ātrāk. Pirms gada, plānojot šos lasijumus, šis pieredzes vēl nebija. Bija tikai milzīga neziņa par notiekošo, par to, cik ilgi tas viss turpināsies, šaubas par konferences dalībnieku tehniskajām iespējām, izvēle starp vairākām pieejamām programmām un, jā, arī kopumā visa notiekošā radīts psiholog̣isks diskomforts un pat bailes.

Neraugoties uz visām šaubām un grūtībām, sestie jauno vēsturnieku zinātniskie lasījumi tomēr notika 2020. gada 27. un 28. novembrī, attālināti. 
Savus referātus nolasīja divdesmit četri jaunie zinātnieki no Latvijas, Lietuvas un Igaunijas. Konferences darbs bija organizēts piecās sekcijās, no kurām divas notika anĝ̣u un trīs - latviešu valodā. Referātos aplūkotie jautājumi hronolog̣iski aptvēra laika posmu no akmens laikmeta līdz pat mūsdienām.

Šajā krājumā publicēti vienpadsmit autoru raksti, kuri pēc konferences pārstrādājuši savus referātus par rakstiem un iesnieguši publicēšanai šajā krājumā. Visi raksti ir tikuši anonīmi recenzēti.

LU doktorante $M g$. hist. Justīne Fišere savā rakstā analizē Rīgas Mazās gildes cunftu amatu statūtos jeb šrāgās noteiktos sodus par dažādiem pārkāpumiem laika posmā no 14. gadsimta otrās puses līdz 17. gadsimta pirmajai pusei. Pētniece iepazīstina ar izmaiņām sodu nomaksas veidos šajā laika posmā un secina, ka šo izmaiņu dinamika liecina gan par cunftu mērḳu un ideālu mainuu, gan arī l̦auj izsekot dažādu politisko, ekonomisko, sociālo un kultūras faktoru ietekmei uz cunftu darbību.

Mg. hist. Aleksandrs Petrovs, balstoties uz būvmateriālu ražošanas nozari kā piemēru, savā rakstā izvērtē rūpniecības atjaunošanu pēc Otrā pasaules kara un tās attīstību 20. gadsimta 40. un 50. gados. Autors secina, ka būvmateriālu ražošanas nozare uzskatāmi parāda problēmas, kas bija raksturīgas visai pēckara saimniecībai Latvijā - darbaspēka, ražošanas līdzekḷu un resursu trūkums, kapitālieguldījumu nesabalansētība, ne vienmēr prasmìga pārvalde, nevienmērīga apakšnozaru attīstība u. tml. Tajā pašā laikā katrai nozarei bija sava attīstības specifika, un, lai gan objektīvi svarīga, būvmateriālu ražošana bija viena no rūpniecības nozarēm, kas atkopās vislēnāk.

LU doktorante $M g$. hist. Guna Plakane aplūko Latvijā 20. gadsimta 20. gados pagrīdē darbojošās Latvijas Komunistiskās partijas aktivitātes, kuras tā ìstenoja caur vienu no savām satelītorganizācijām - Rīgas Arodbiedrību centrālbiroju. Pētniece rakstā izklāsta, ka centrālbiroja darbības centrā bija nevis tā oficiālais mērḳis aizstāvēt strādnieku intereses, bet gan LKP noteiktās politiskās līnijas realizācija: tas vērsās pret pastāvošo valsts iekārtu, iestājās par radikāliem risinājumiem sociālajā un politiskajā jomā un ciešiem sakariem ar PSRS.

LU doktorants $M g$. hist. Reinis Ratnieks pievēršas nacionālās pretošanās kustības vēstures izpētei, analizējot partizānu cīṇu Valmieras apriṇ̣̂ī atspoguḷojumu PSRS literatūrā. Pētnieks secina, ka, lai arī par Valmieras apriņ̧̧a partizānu darbību publicēts daudz literatūras, tajā ietvertie fakti un spriedumi ir pakārtoti okupācijas režīma ideolog̣izētajam skatījumam uz nacionālajiem partizāniem kā kara noziedzniekiem vai bandītiem. Attiecīgi PSRS laika literatūrā vērojama arī nevērīga izturēšanās pret faktu precizitāti, jo galvenais tās uzdevums ir veidot režīmam atbilstošu priekšstatu par nacionālajiem partizāniem, nevis atspoguḷot objektīvu to darbības vēsturi.

Vìtauta Dižā universitātes (Lietuva) doktorante Karina Račaitīte analizē Kauṇas rajonu iedzīvotāju atmiṇas, meklējot atbildi uz jautājumu, kas 
veido šo rajonu iedzīvotāju dažādu paaudžu identitāti. Analizējot 115 interviju materiālu, autore secina, ka paaudžu robežas drīzāk nosaka nevis cilvēku dzimšanas gads, bet gan noteiktas, šai paaudzei raksturīgas atminas un pieredze, kā arī izklāsta katras nodalītās Kauṇas iedzīvotāju paaudzes raksturīgākos atminuu elementus.

Mg. hist. Margarita Novikova piedāvā lasītājiem ieskatu Livonijas reformācijas laika vēsturē, analizējot 1552. gada Livonijas kārtu sapulces recesu, tā priekšvēsturi un saiknes ar Rīgas strīdu 1549.-1554. gadā. Autore tos sapulcē pieņemtos lēmuma punktus, kuri attiecās uz reliǵiju, analizē ciešā kontekstā ar tā laika politisko situāciju, konkrēti - Rīgas arhibīskapijas kārtu politiku; raksts pievēršas 1552. gada kārtu sapulces recesa radīšanas apstākḷiem, izdevējiem un avotiem, nosaka formulētā lēmuma teksta politisko kontekstu un mērk,us.

Mg. hist. Ginta Skutāna interešu centrā ir Latvijas kultūrvēsturē nozīmīgu vietu ieṇēmušās Beverīnas pils ǵeogrāfiskās atrašanās vietas meklējumi. Pētnieks argumentēti aplūko devin,as ticamākās leǵendārās pils atrašanās vietas: Kauguru Pekas kalns, Rauna, Trikāta, Rubene, Valmieras pilsdrupas un Lucas kalns, Zilaiskalns, Viḷumi (Vaidavas pagastā) un Cimpēni.

LU doktorante $M g$. hist. Anastasija Smirnova analizē Elberfeldes sociālās aprūpes sistēmas pamatprincipu ienākšanu Latvijas teritorijā 19. gadsimta beigās - 20. gadsimta sākumā. Autore rakstā ieskicē šīs sistēmas pamatprincipus, kā arī šo sistēmu saistīto ideju pakāpenisku parādīšanos Latvijas medijos un pēc tam arī atsevišķu elementu ieviešanu praksē, galvenokārt ostas pilsētās Rīgā un Liepājā. Visticamāk, Elberfeldes sistēma Latvijā ienākusi ātrāk nekā citās Krievijas impērijas daḷās.

Daugavpils Universitātes doktorants $M A$ arhīvniecībā Kaspars Strods aplūko Otrā pasaules kara piemiņas vietas Rēzeknē un ar šo pieminekḷu piemēru atklāj problēmas mūsdienās pastāvošajās pagātnes interpretācijas tendencēs. Pētnieks atklāj šo problēmjautājumu saistību gan ar padomju ideoloǵiskajiem uzstādījumiem, gan arī ar vēsturisku notikumu pieminēšanas politiku mūsdienu Rēzeknē. Visu šo procesu rezultātā pieminekḷi nereti dažādās sabiedrības daḷās tiek uztverti izteikti atšksirīgi, kā arī bieži vien cilvēkiem nav zināma plašāka objektīva informācija par vēstures notikumiem, kuru pieminai veltīti šie pieminekḷi.

Vītauta Dižā Universitātes (Lietuva) doktorants Evalds Vilkončus savā rakstā analizē valsts slimnīcu ēku attīstību starpkaru Lietuvā (1918-1940), aplūkojot Lietuvas slimnīcu dizaina īpatnības un attīstību. Šajā laikā notikušās ārējās un iekšējās izmaiņas būtiski ietekmēja Lietuvas slimnīcu arhitektūras attīstību arī vēlākos periodos, tādēḷ šīs slimnīcu ēkas var uzskatīt par nozīmīgiem, lai arī mazpazīstamiem Lietuvas starpkaru arhitektūras piemēriem.

Mg. hist. Mikus Žagatas raksts veltīts Vidzemes provinces (Livland) lokālās un Zviedrijas karalistes centrālās administrācijas organizētajiem pasākumiem 
provincē izvietoto bruņoto vienību apgādei ar nepieciešamajiem resursiem kaujas spēju nodrošināšanai 1700. gada nogalē un 1701. gada pirmajā pusē. Autors pierāda, ka zviedru armijas uzturēšana šajā laika posmā sākumā bij sarežğìta un izteikti negatīvi ietekmēja visas provinces ekonomisko situāciju, kas savukārt liek apšaubīt šì karaspēka spējas nodarìt provincē zaudējumus tādā apmērā, kā tas līdz šim ticis uzskatīts.

COVID-19 pandēmija ir piespiedusi cilvēkus daudz vairāk nekā jebkad agrāk iesaistìt savās ikdienas norisēs tehnolog̣ijas - pāriet uz attālinātu darbu, attālinātu saziņu ar tuvajiem un arī attālinātām konferencēm. Daudz kas no pandēmijas ieviestajiem jauninājumiem noteikti paliks mūsu ikdienā arī turpmāk. Visticamāk, arī pēcpandēmijas pasaulē vairākums starptautisku tematisku konferenču visā pasaulē pulcēs savas jomas speciālistus gan klātienes, gan attālinātās sekcijās. Tomēr vienlaikus ar jaunā ienākšanu saglabājas arī tradicionālais. Tādēl Jauno vēsturnieku zinātnisko lasījumu organizatori un šì krājuma sastādītāji esam priecīgi piedāvāt lasītājiem šo rakstu krājumu gan tradicionālas drukātas grāmatas formā, gan arī elektroniski pieejamu LU Repozitorijā.

Kristīne Beķere

LU Latvijas vēstures institūts 


\section{PREFACE}

The Scholarly Readings of Young Historians have already become an established annual tradition in the scientific life of Latvia, as has the collection of articles following the Readings. In the spring of 2020, the organizers of the Readings, commencing preparations for the $6^{\text {th }}$ Readings of Young Historians, decided that the time had come to expand this tradition to a new level by holding international Readings. For the first year, the event was conducted on the scale of the Baltic states.

The organization of the conference, as well as preparation and publication of the current collection are financially supported by the National Research Programme funded by the Ministry of Education and Science "Latvian Heritage and Future Challenges for the Sustainability of the State"; project "Interaction between the individual, the society and the state in process of the history of Latvia: Conflicting values and formation of shared values during historical turning points", project No. VPP-IZM-2018/1-0018.

The organization of the $6^{\text {th }}$ Scholarly Readings of Young Historians involved a number of challenges. The first task was to introduce the tradition of Readings to Lithuanian and Estonian colleagues. We are grateful and happy for the interest shown by the young historians of the neighbouring countries. However, the greatest challenge by far during the conference was the COVID-19 pandemic and the associated assembly restrictions. In the spring, when the current year's Readings should usually be announced, the situation was precarious, full of suspense and ambiguity. Today, a year later, when the vaccine is available and we are accustomed to the circumstances when remote format is the most likely arrangement in which any event can take place in a certain and safe manner, the new situation has already become commonplace.

The restrictions needed to contain the pandemic have become a factor to be reckoned with and largely predictable. Most of those involved in science and higher education are already accustomed to working in the virtual environment, meeting through Zoom or MS Teams programs. In many cases, it is indeed even more convenient and faster. A year ago, while planning these Readings, there was as yet no such experience, instead, 
there was just a great deal of uncertainty about the processes, the duration of extraordinary situation, the doubts about technical resources available to the conference participants, the guesswork in choice amongst several programmes available and, clearly, the overall psychological discomfort and even fear.

Despite all the apprehension and difficulties, the $6^{\text {th }}$ Scholarly Readings of Young Historians took place on November 27 and 28, 2020, remotely. Twenty-four young scientists from Latvia, Lithuania and Estonia read their reports. The work of the conference was organized in five sections, two of which were held in English and three - in Latvian. The issues addressed in the reports chronologically encompassed the period from the Stone Age to the present day.

Eleven authors' articles have been published in this collection - these researchers have revised their papers after the conference and submitted them for publication. All the articles have been anonymously reviewed.

Doctoral student of the University of Latvia, Mg. hist. Justinne Fišere analyses the penalties for various violations set forth in the statutes of the Riga Artisans Guild (Zunft) of the Small Guild in the period from the second half of the $14^{\text {th }}$ century to the first half of the $17^{\text {th }}$ century. The researcher presents changes in the methods of payment of fines during this period, concluding that the dynamics of these changes indicate an alteration in the goals and ideals of the artisan guilds, as well as enable researchers to trace the impact of various political, economic, social and cultural factors on the activities of artisan guilds.

Mg. hist. Aleksandrs Petrovs, basing his research on the building materials industry as an example, in his article evaluates the overall renewal of industry after the Second World War and its development in the 1940s and 50s. The author concludes that the construction materials industry clearly reveals the problems that were characteristic of the whole post-war economy in Latvia lack of labour, means of production and resources, imbalance of capital investments, management at times lacking in skill, uneven development of sub-sectors, etc. At the same time, each sector had its own specifics of development and, despite its objective importance, the production of building materials was one of the slowest-recovering industries.

Doctoral student of the University of Latvia, Mg. hist. Guna Plakane researches the activities of the Latvian Communist Party, which was operating underground in Latvia in the 1920s through one of its satellite organizations, the Riga Trade Union Central Office. The researcher explains that the focus of the central office was not on its official goal of defending the interests of workers, but on implementation of the political direction set by the LCP: it opposed the existing state system, advocated radical social and political solutions and closer ties with the USSR. 
Doctoral student of the University of Latvia, $M g$. hist. Reinis Ratnieks focuses on the study of the national resistance movement history, analysing the reflection of guerrilla struggle in Valmiera district in the USSR literature. The researcher concludes that although extensive literature has been published about the activities of the partisans of Valmiera district, the facts and judgments contained therein are subordinated to the ideological view of the national partisans as war criminals or bandits. Accordingly, the literature of the USSR period considering this theme disregards the accuracy of facts, because its main task is to form a regime-appropriate picture of the national partisans instead of reflecting an objective history of their activities.

Doctoral student at Vytautas Magnus University (Lithuania) Karina Račaityte analyses the memories of residents of certain Kaunas districts, looking for an answer to the question - what forms the identity of different generations of the residents of these districts? Analysing the material of 115 interviews, the author concludes that the boundaries of generations are determined not by people's years of birth, but by certain memories and experiences specific to the respective generation; the article also outlines the most characteristic memory elements of each generation.

$M g$. hist. Margarita Novikova offers the readers an insight into the history of the Livonian Reformation, analysing the agreement texts produced during the assembly of Livonian estates in Pernau in 1552, their background and links with the Riga dispute of 1549-1554. The author examines the decision points adopted at the meeting, which are related to religion, in a close context with the political situation of that time, specifically - the policy of the Riga Archdiocese; the article addresses the circumstances, publishers and sources of the agreement texts from the round of meetings of 1552, determines the political context and objectives of the text of the formulated decision.

The focus of $M g$. hist. Gints Skutāns' interests is the search for the geographical location of Beverina Castle, which has taken an important place in the cultural history of Latvia. The researcher evaluates the nine most probable locations of the legendary castle: Kauguri Peka Hill, Rauna, Trikāta, Rubene, Valmiera Castle ruins and Lucas Hill, Zilaiskalns, Viḷumi (Vaidava parish) and Cimpēni.

Doctoral student of the University of Latvia, $M g$. hist. Anastasia Smirnova inspects the entry of the basic principles of the Elberfeld social care system into the territory of Latvia at the end of the $19^{\text {th }}$ century - the beginning of the $20^{\text {th }}$ century. The author in her article outlines the basic principles of this system, as well as the gradual appearance of the ideas related to this system in the Latvian media and then also the implementation of certain elements in practice, mainly in the port cities of Riga and Liepāja. Most likely, the Elberfeld system was introduced in Latvia sooner than in other parts of the Russian Empire. 
Doctoral student of the University of Daugavpils, MA in archival sciences Kaspars Strods looks at the memorial sites of the Second World War in Rēzekne and through the example of these monuments reveals the problems in the current tendencies of interpreting the past. The researcher exposes the connection between these problems and the Soviet ideological precepts, as well as the links with the policy of commemorating historical events implemented in Rezzekne today. As a result of all these processes, monuments are often perceived very differently in different parts of society, and often people do not have an access to objective information about the historical events commemorated by these monuments.

Doctoral student at Vytautas Magnus University (Lithuania) Evaldas Vilkončius in his article explores the development of state hospital buildings in interwar Lithuania (1918-1940), analysing the design features and development of Lithuanian hospitals. The external and internal changes that took place during this period significantly influenced the development of Lithuanian hospital architecture in later periods, therefore, these hospital buildings can be considered as important, albeit little-known, examples of Lithuanian interwar architecture.

Mg. hist. Mikus Žagata's article is devoted to the organizational measures taken by the local administration of Vidzeme province (Livland) and the central administration of the Kingdom of Sweden to supply the armed units located in the province with the necessary resources for combat capabilities in late 1700 and the first half of 1701. The author proves that the maintenance of the Swedish army during this period was initially difficult and had a markedly negative effect on the economic situation of the whole province, which, in turn, calls into question the ability of these troops to cause damage in the province to the previously estimated extent.

The COVID-19 pandemic has compelled people to incorporate technology into their daily lives more than ever before - transferring to distance work, remote communication even with friends and family and also remote conferences. Many of the innovations introduced by the pandemic will certainly remain a part of our daily lives. In the post-pandemic world, too, most international thematic conferences around the world are likely to bring together experts in their fields both in face-to-face sessions and remote digital presentations. However, with the arrival of the new, the traditional remains. Therefore, the organizers of the Scholarly Readings of Young Historians and the compilers of this collection are happy to offer readers the current collection of articles both in the form of a traditional printed book and electronically at the Repository of the University of Latvia. 


\title{
RĪGAS MAZĀS G̣ILDES CUNFTU PĀRKĀPUMU UN SODU ANTROPOLOG̣IJA, 14. GADSIMTA OTRĀ PUSE - 17. GADSIMTA SĀKUMS: ŠRĀGU TEKSTU PIEMËRS
}

\author{
JUSTITNE FIŠERE \\ Mg. hist., LU doktorante \\ E-pasts: fiserejustine@gmail.com
}

\begin{abstract}
ANOTĀCIJA
Rīgas Mazās giildes cunftu darbību regulēja amatu statūti jeb šrāgas. Cunftes bija organizācijas, kuru galvenais mērḳis bija amatnieku profesionālās darbības noteikšana, tās daḷeji regulēja arī sociālos un religískos jautājumus. Cunftu šrāgās tika ietvertas kopienas intereses un mērḳi, katrs izdarītais likuma pārkāpums tos apdraudēja. Par statūtu pārkāpumu atkarībā no nodarījuma smaguma tika noteikts sods. Mainoties Rīgas pilsētas politiskajiem, ekonomiskajiem, sociālajiem un reliǵiskajiem faktoriem, atbilstoši jaunajiem apstākḷiem mainījās arī cunftu pieṇemtie likumi un sodi par pārkāpumiem. Pētījuma mērḳis ir sniegt priekšstatu par Rīgas Mazās ǵildes cunftu pārkāpumu un sodu antropologiijas problemātiku, analizējot pilsētas rātes apstiprinātos cunftu statūtus.
\end{abstract}

Atslēgas vārdi: Rīgas Mazā ǵilde, cunftes, šrāgas, amatu statūti, Rīgas pilsēta, viduslaiku pilsētas amatniecība.

\section{IEVADS}

Pirmās pilsētu amatnieku apvienības vācu zemēs tika izveidotas jau 12. gadsimtā, bet straujāka to attīstība ir vērojama 13. gadsimtā (Isenmann 2014, 804). Ierodoties Rīgā no vācu zemēm, Rīgas pilsētas amatnieki jau bija pazīstami ar šìm organizāciju formām (Fišere 2020, 57). Sākotnēji bīskaps Alberts izdeva aizliegumu Rīgā organizēties ǵildēs, taču jau pēc 1221. gada aizliegums vairs nebija spēkā (Zeids 1978, 60), un jau 13. gadsimta pirmajā pusē tika izveidota Svētā Krusta gilde un Svētās Trīsvienības giilde. 
1252. gadā, abām šìm ǵildēm apvienojoties, izveidojās Svētā Gara giilde (Brunstermann 1902, 8). Šajā gildē bija apvienojušies gan tirgotāji, gan amatnieki. Ģildes locekḷu kopā sanākšanas notika ğildes lielajā zālē jeb Minsteres istabā. Atšķirīgo interešu un amatnieku skaita pieauguma dẹl ar laiku tie nodalījās no tirgotājiem un sāka pulcēties Zēstes istabā. Dokumentos tā pirmo reizi ir minēta 1330. gadā (Zeida 1967, 32). No Zēstes istabas ar laiku izveidojās Mazā giilde, bet no Minsteres istabas - Lielā ǵilde. Atšḳirībā no Rīgas pirmajām ǵildēm, kurās dominēja reliǵgiskie un sociālie mērḳi, jaunajām ğildēm - Lielajai giildei un Mazajai giildei - par virsmērḳi kḷuva profesionālo jautājumu risināšana. 1352. gada 18. novembrī, Svētās Elizabetes dienā, Rīgas pilsētas rāte apstiprināja Mazās ǵildes statūtus jeb šrāgas (Stieda, Mettig 1896, 365), kas norāda uz giildes leğitīmu darbību pilsētā.

Mazajā gildē amati sāka organizēties mazākās struktūrvienībās - cunftēs (Zunft) (Heusinger, 2010, 38), pārṇemot Mazās ǵildes organizācijas formas. Rīgas Mazā gilde bija kā jumta organizācija, kas kopš 14. gadsimta otrās puses apvienoja pilsētas vācu amatus. Pirmās Mazās ǵildes cunftu šrāgas Rīgas rātē apstiprinātas jau 1360. gadā (zeltkaļu šrāgas) (Stieda, Mettig 1896, 294-297), tām sekoja vairāku citu amatu šrāgu apstiprināšana mucinieku (1375) (Stieda, Mettig 1896, 260-263), kalēju (1382) (Stieda, Mettig 1896, 456-460), mūrnieku (1390) (Stieda, Mettig 1896, 422-426), maiznieku (1392) (Stieda, Mettig 1896, 239-242), ādas apstrādātāju (1397) (Stieda, Mettig 1896, 378-382), drēbnieku (14. gadsimta beigu) (Stieda, Mettig 1896, 478-481), kurpnieku (14. gadsimta beigu) (Stieda, Mettig 1896, 528-532) šrāgas. 15. gadsimtā jaunu amatu šrāgas vai šrāgu pārrakstī̌sana nav konstatējama, bet 16. gadsimtā izveidojās jostnieku cunfte (1512) (Stieda, Mettig 1896, 338-343), stiklinieku cunfte (1541) (Stieda, Mettig 1896, 283-288), galdnieku cunfte (1535) (Stieda, Mettig 1896, 664-665). Pēc Reformācijas, amatiem specializējoties šaurākās nozarēs, no jau esošajiem amatiem sāka atdalīties jauni amati, kas ar laiku izveidoja cunftes - no kalēju cunftes atdalījās un savu cunfti radīja atslēdznieki (1581) (Stieda, Mettig 1896, 448-455), bet no drēbniekiem noškīirās cepurnieki (1595) (Stieda, Mettig 1896, 348-356) u. c. Vairāku cunftu pirmās šrāgas nav saglabājušās.

Bez Mazās ǵildes amatiem pilsētā darbojās vēl vairāki citi amati, kurus dēvēja par kauna amatiem (pirtnieki, linuvērpēji), un tā sauktie latviešu palīgamati, kuri rakstītajos avotos minēti jau kopš 13. gadsimta. Pirmās latviešu palīgamatu šrāgas Rīgas rātē apstiprinātas jau 14. gadsimtā (alus nesēji, 1386. gadā) (Taube 1980, 21).

Rīgas Mazās gildes cunftu darbība tika stingri reglamentēta amatu statūtos jeb šrāgās (Schragen), kas bija oficiāli, Rīgas pilsētas rātes apstiprināti likumi. Rīgas amatnieku šrāgas tika pārṇemtas no vācu zemēm. Vēlāk, līdzīgi citiem viduslaiku likumiem, piemēram, pilsētas statūtiem (Napiersky 1876, 
133-200), šrāgas tika pārstrādātas atbilstoši vietējiem Rīgas pilsētas sociālekonomiskajiem un kultūras apstākḷiem.

Cunftu statūti jeb šrāgas ir dokuments, kurā ietverti organizācijas profesionālie un morāles principi. Informācija par statūtu izpildi de facto ir pieejama citos dokumentu tekstos, kas paredzēti amata iekšèjām vajadzībām, piemēram, amata grāmatās (Amtsbuch). Salīdzinot šrāgās minētos likumus ar citiem dokumentiem, būs iespējams noteikt, kā amatu likumi ir tikuši istenoti dzīvē.

Liecības par šrāgu faktisko darbību nereti atrodamas komentāros, kas pievienoti dokumentam vēlākā laikā. Labojumi, kas pievienoti atsevišķiem šrāgu punktiem, liecina par to neatbilstîbu jaunajiem apstākḷiem un norāda, ka bija nepieciešamas izmaiņas likumā. Šrāgās veiktas arī piezīmes par likumiem, kas tā arī nav izmantoti praksē. Pētijjuma mērḳis ir sniegt priekšstatu par Rìgas Mazās gildes cunftu pārkāpumu un sodu antropoloǵijas problemātiku, analizējot cunftu statūtus.

\section{CUNFTU DARBīBAS REGLAMENTĒŠANA ŠRĀGĀS}

Rīgas Mazās ǵildes amatnieki bija Rīgas pastāvīgie iedzīvotāji. Pilsētas likumi uz amatniekiem attiecās tāpat kā uz pārējiem pilsētniekiem, tajos detalizēti izskatīti gan politiskie, gan ekonomiskie, gan sociālie un citi jautājumi. Katram likuma pārkāpumam bija piemērots sods (Napiersky 1876, 133-200). Amatnieki kā Rīgas pilsoṇi vienlaikus bija pakḷauti arī citiem likumiem, kas regulēja pilsētas sabiedrību.

Pilsētas likumiem paralēli pastāvēja amatnieku organizāciju šrāgas, tādējādi amatnieku ikdiena bija stingri reglamentēta, jo tika pakḷauta vairāku institūciju likumiem. Pilsētas tiesa par smagākiem noziegumiem varēja noteikt dažādus miesas sodus, piemēram, rokas nociršanu par zādzību vai pielikšanu pie kauna staba. Par īpaši smagiem miesas noziegumiem vai morāles pārkāpumiem tika piespriesti arī nāves sodi. Cunftes noteiktais bargākais sods bija izslēgšana no amata.

Šrāgās norādīts, ka visiem, kuri piederēja pie amata - gan meistaram, gan viņa ǵimenei, zeḷliem (Gesell) un mācekḷiem (Lehr-Jungen), ir jābūt cunftes cienīgiem. Piederība amatam norādīja statusu sabiedrībā, kas attiecībā pret pārējo pilsētas sabiedrību prasīja attiecīgu normu ievērošanu. Kā viena no šādām prasībām cunftu šrāgās tika minēta piederība godīgai ǵimenei, kura atbilstu cunftes noteiktajiem standartiem, piemēram, echt und recht geboren. Pēc Reformācijas līdztekus citām izmain̄ām tika pievienota prasība piederēt Augsburgas konfesijai (Stieda, Mettig 1896, 350, 16. punkts). Līdztekus pārkāpumiem un tiem sekojošiem sodiem organizācijā pastāvēja arī dažāda veida aizliegumi, kam bija pakḷauti cunftes amatnieki un viṇu gimenes. 
Ģimene cunftē bija nozīmīga, jo visi tās locekḷi tika iesaistīti ražošanā. Paralēli baznīcas noteiktajām laulības dzīves prasībām un pilsētas likumiem, kas regulēja laulības dzīvi, arī cunftēm bija savas prasības šajā jautājumā. Tā kā visa meistara ǵimene bija piederīga amatam, arī sievas izvēle bija būtiska. Piemēram, maiznieku cunftes 1392. gada šrāgās ir noteiktas prasības amata meistara sievai (Stieda, Mettig 1896, 240, 5. punkts). Amatnieku kāzas ietekmēja arī Rīgas pilsētas izdotie Kāzu un apg̣ērbu nolikumi jeb greznības noliegumi. Tajos tika norādīts, kādām jābūt Mazajai ǵildei piederīgo amatnieku kāzām, piemēram, cik viesu drīkst ielūgt (Kāzu un apǵērbu nolikums 1593, 13, 3. punkts), cik puišu drīkst nolīgt kāzās, lai apkalpotu galdus (Kāzu un apgeērbu nolikums 1593, 16, 12. punkts) u. c. Rīgas pilsētas rātes izdotie greznības noliegumi noteica, ne tikai kādām bija jābūt pilsētnieku kāzām atbilstoši statusam sabiedrībā, bet arī kārtību kristībās, bērēs un ierobežoja pārmērību apgeērbā (Taube 1960, 287-308).

Piederība cunftei meistaram un viṇa gímenei sniedza arī sociālās garantijas. Strukturētajā viduslaiku un agro jauno laiku pilsētas sabiedrībā, lai nodrošinātu savu un gimenes labklājību, bija nepieciešams piederēt pie kādas organizācijas. Cunfte ne tikai veicināja vienlīdzīgas ražošanas iespējas pilsētas amatniekiem, bet arī nodrošināja atbalstu meistaram slimības gadījumā. Cunfte noteica, kā atraitnei jārīkojas ar aizgājušã meistara darbnīcu (Ojala, 2012, 199-220), kā arī ietekmēja atraitnes ikdienas dzīvi (Heusinger, 2009, 72). Amats nodrošināja arī apbedī̌̌anu atbilstoši baznīcas bēru tradīcijām. Cunftu šrāgās ir norādīta pat konkrēta naudas summa apbedīšanai, kuru sedz amats, kā arī minēti pienākumi, kas bija jāveic amata brāliem, godinot aizgājēju (Stieda, Mettig 1896, 529, 8. punkts).

Cunftēm bija raksturīga vecuma hierarhija, piemēram, stiklinieku cunftes 1541. gada šrāgās tika noteikts, ka jaunākajam amata brālim bija jāapkalpo vecākie amata brāḷi tik ilgi, kamēr viņš vairs nav jaunākais (Stieda, Mettig 1896, 288, 32. punkts). Vecie meistari tika cienīi, un vinus atbalstijja arī vecumdienās. Ja amatā bija kāds tik vecs, ka pats vairs nespēja nopelnīt naudu, lai samaksātu par kopīgo iedzeršanu, amata dzīrēs drunke viņam kopīgā iedzeršana pienācās bez maksas (Stieda, Mettig 1896, 532, 25. punkts).

Šrāgas noteica amatnieka profesionālo dzīvi, ietekmēja ikdienu un kontrolēja sociālos un kultūras faktorus. Tās tika izstrādātas, sargājot kopienas mērḳus un intereses. Paralēli šrāgās minētajiem regulējumiem par jauno meistaru uzṇemšanu amatā, prasībām pret izstrādājumu kvalitāti, sociālās palīdzības un citiem jautājumiem tika minēti sodi par šo regulējumu pārkāpumiem. Soda nomaksa mainījās atbilstoši vēsturiskajam kontekstam. 


\section{ŠRĀGĀS MINĒTIE SODĀMIE PĀRKĀPUMI}

Cunftu statūtos galvenokārt dominēja likumi, kas regulēja profesionālos jautājumus. Šrāgas atspoguḷo prasības pret darba kvalitāti, pieņemto darba kārtību un organizatoriskiem jautājumiem. Likumi veidoti, lai mazinātu konkurenci starp meistariem un veicinātu vienlīdzīgas ražošanas iespējas cunftē, piemēram, nosakot skaitu, cik algotu darbinieku drīkst pien,emt vienā meistara darbnīcā, nosakot laiku, kad drīkst pien,emt kalpus (knecht) u. c. (Stieda, Mettig 1896, 241, 11. punkts). Vairākās cunftu šrāgās ir noteikts sods par šo nosacījumu pārkāpšanu.

Labā reputācija sabiedrībā cunftēm bija atkarīga no darba un materiāla kvalitātes. Piemēram, zeltkaḷu cunftes 1542. gada šrāgās ir rakstīts: “[..] katram Rīgas zeltkalim ir jāapstrādā labs zelts un sudrabs, tas ir, pēc četrpadsmit lotu proves, kā to apstrādā K,elnē un Lībekā un visam, ko apstrādā un kausē svešam cilvēkam un kam var iespiest zīmi, eltermanim ir jāiespiež mūsu godājamās rātes un zeltkaḷu zīme [..]" (Stieda, Mettig 1896, 299-300, 3. punkts). Tam seko nākamais punkts: "[..] neviens zeltkalis nedrīkst iedrošināties apstrādāt mazvērtīgāku kā Reinas (Rinisch) zeltu un nedrīkst tajā ielikt stiklu, bet tikai dārgakmeni" (Stieda, Mettig 1896, 300, 4. punkts). Katras cunftes šrāgās tika ietverti amatniecības izstrādājumu kvalitātes standarti.

Kā profesionālais pārkāpums jāmin arī profesionālās disciplīnas neievērošana. Katra cunftes meistara pienākums bija ierasties uz amata sapulcēm. Neierašanās gadījumā bija jāmaksā šrāgās noteiktais sods. Sodīti tika arī tie, kuri sapulces kavēja, piemēram, cepurnieku cunftes 1595. gada šrāgās ir norādīts, ka tas, kurš neierodas uz amata sapulci, maksā divas markas amata lādē, ja vien viṇam nav kāds nopietns attaisnojums, kāpēc viṇš nav ieradies, bet tas, kurš lēni nāk (kavē), tam ir jāmaksā sods viena marka (Stieda, Mettig 1896, 350, 13. punkts).

Reliǵiskos jautājumus noteica pilsētas un baznīcas likumi. Tā cunftu šrāgas noteica, ka amatniekiem nav aț̣auts strādāt svētdienās. Par noteikuma pārkāpumu bija paredzēts sods. Zellis, kura nolīgtais laiks pie viena meistara bija beidzies, pie otra meistara varēja pāriet vienīgi svētdienā pēc dievkalpojuma (Zeida 1967, 92).

Nozīmīgas bija apbedīšanas tradīcijas. Amats piedalījās mirušā cunftes locekḷa bēru finansēšanā. Katra amatnieka pienākums bija piedalīties amata brāla bērēs, citādi viņš saņēma sodu (Stieda, Mettig 1896, 483, 17. punkts). Viduslaiku un agro jauno laiku sabiedrības attieksme pret nāvi bija l,oti nopietna - pārkāpums pret bēru rituāliem apdraudēja arī pašu pārkāpēju. Kurpnieku 14. gadsimta beigu šrāgās noteikts, ka Vasarsvētkos (pinxten), kad notika amata sapulce un dzīres (drunke), eltermanim (Eltermann) bija jādodas uz Svētā Pētera baznīcu un jāziedo amata mirušo brāḷu piemiņai trīs ēru apmērā 
(Stieda, Mettig 1896, 531, 23. punkts). Reliǵiskās tradīcijas cunftē veidoja un saglabāja amatnieku kolektīvo atminuu (Ojala, 2013, 84).

Šrāgās minēti punkti, kuros sniegtas norādes par amatnieku savstarpējo attiecību uzturēšanu. Meistariem bija jāciena vienam otru, strīdu gadījumā viņi saṇēma sodu. Par nelieliem nodarījumiem - cita meistara apvainošanu vai tml. - strīdi tika atrisināti amatu sapulcēs, vainīgajam saņemot šrāgās noteikto sodu, bet, ja nodarijums bija lielāks vai neattiecās uz amatu, meistari bija pakḷauti Rīgas pilsētas likumiem. Kā minēts cepurnieku cunftes šrāgās, šādi pārkāpumi tika izskatīiti pilsētas (Stadtgericht) vai zemes (Landgericht) tiesā (Stieda, Mettig 1896, 350, 15. punkts). Smagākie pārkāpumi bija tie, kas apdraudēja visas cunftes reputāciju. Meistaru, kurš nav "amata cienīgs", izslēdza no cunftes. Līdzīgas prasības tika attiecinātas uz citiem cunftei piederīgajiem. Piemēram, ja meistara atraitne ir apprecējusies ar amata necienīgu zelli vai viṇi laulībā nedzīvo godīgi, vinii no amata jāizslēdz (Stieda, Mettig 1896, 304, 18. punkts).

Piemērojot sodus par pārkāpumiem, šrāgās tika ievērots vienlīdzības princips - visi cunftes amatnieki ir vienlīdzīgi, viniem ir vienādas tiesības un pienākumi pret darbu un tā kvalitāti. Cunfte deva meistariem stabilus dzīves apstākḷus un drošības garantijas dažādās krīzes situācijās.

\section{ŠRĀGĀS MINĒTIE SODI}

Atkarībā no pārkāpuma smaguma kā soda nomaksa šrāgās tika pieprasīti patēriņa priekšmeti vai nauda. Smagākais sods bija izslēgšana no cunftes uz noteiktu laiku vai pavisam.

Soda nomaksai patēriņa priekšmetu veidā šrāgās tiek minēts vasks un alus. Šāds samaksas veids visbiežāk bija raksturīgs sodu nomaksai pirms Reformācijas. Vasks tika izmantots diviem mērḳiem: reliğiskajiem rituāliem un amata patēriņam. Šāds soda mērs viduslaikos - līdz pat 16 . gadsimta sākumam - bija izplatīts, jo vasks galvenokārt tika izmantots altāru svecēm. Vairākos gadījumos maksājums vaskā netiek norādīts kā maksājums amatam, bet svētajam aizbildnim jeb amatu altāriem baznīcās. Vasks tika izmantots arī pašu cunftu sanāksmju un dzīru telpu apgaismojumam. Pieprasìtais vaska daudzums bija atkarīgs no nodarijuma smaguma.

Ja vasks bija paredzēts amata iekšējai lietošanai, šrāgu tekstā tiek lietots apzīmējums "kompānijai vai amatam" (kumpenye / cumpanye u. c., ampt). Savukārt, ja vasks bija paredzēts svecēm religiskajos rituālos, piemēram, "gaismas uzturēšanai" altārī vai aizlūgumiem, tiek lietots simbolisks apzīmējums "gaisma" (lychten / lychten to hulpe). Piemēram, kalēju 1382. gada šrāgās tiek norādīts apzīmējums "gaisma", kas jāsaprot kā altāris (Stieda, Mattig 1896, 458, 16. punkts). Izprast šrāgās apzīmējumu "gaisma" palīdz ieraksti amata 
grāmatā, kurā norādīts konkrēts maksājuma mērḳis - visbiežāk vasks Svētajam Lojem jeb amata aizbildnim Svētajam Elīgijam - "viens lispunts vaska Lojem" (Mettig 1890, 24, 53. punkts). Vienīgā Mazās ǵildes cunfte, kuras šrāgu tekstā tiek minēts altāra nosaukums, ir maiznieku cunfte. 1392. gada maiznieku cunftes šrāgās minēts: "Viṇam ir jāmaksā viens lispunts vaska Svētajai Miesai [par labu Svētās Miesas altārim]" (Stieda, Mettig 1896, 240, 9. punkts).

Soda nomaksa ar alu ir konstatējama daudz retāk nekā ar vasku. Alus kā soda nomaksa bija paredzēta cunftes sociālajām vajadzībām. Alus patēriņš organizācijā bija liels, to lietoja gan sapulcēs, gan svētkos. Visbiežāk alu tomēr min kā samaksu, piemēram, ar alu cunftei tiek maksāts par katra jaunā mācekḷa uzṇemšanu (Stieda, Mettig 1896, 531, 19. punkts). Soda nomaksa ar alu tiek konstatēta vairākos gadījumos. Maiznieku 1392. gada šrāgās kā sods par noteiktā laika neievērošanu kalpu nolīgšanā līdztekus divām markas mārcin̄ām vaska jādod arī viena muca alus (Stieda, Mettig 1896, 241, 11. punkts).

Šāda cunftu šrāgās minētā soda nomaksa patēriņa priekšmetu veidā var norādīt uz samērā nelielo naudas apgrozījumu Rīgas pilsētā (Berga 2003, 13). Visbagātākā - zeltkalı u - cunfte sodu nomaksāja tikai naudā vai sudrabā. Soda nomaksa naudā laikā pirms Reformācijas atseviš̌sos gadījumos ir prasīta arī citos amatos, bet retāk nekā vasks. Piemēram, 14. gadsimta kurpnieku šrāgās noteikts, ka par kurpju izlikšanu pārdošanai pirms dievkalpojuma beigām Svētā Pētera baznīcā sods ir divi ārtigi (Stieda, Mettig 1896, 531, 18. punkts). Domājams, soda nomaksu naudas veidā saṇēma pilsētas rāte. Arī citi piemēri liecina, ka pilsētas rāte par cunftu amatnieku pārkāpumiem soda nomaksu sañēma tikai naudā. Piemēram, zeltkaḷu cunftes 1360 . gada šrāgas norāda, ka "tam, kas strādā svētā dienā, rātes kungiem jāmaksā sods pusmārciņa feniņu” (Stieda, Mettig 1896, 296, 10. punkts). Jāsecina, ka tas ir pārkāpums ne tikai pret amatu, bet pret pilsētas sabiedrību un tās pieñemtajām reliǵiskajām normām.

Naudā izteiktā soda samaksa atspoguḷo Rīgas pilsētas naudas apgrozību. Šrāgās ir minēti gan monētu nomināli - piemēram, markas, ārtigi, feniņi -, gan svara mērvienības, kādās, piemēram, zeltkalı cunftei jāmaksā soda naudas ekvivalents dārgmetālā. Zeltkaḷu 1542. gada šrāgās teikts: “Ja eltermanim kāds sūdzas par zeltu vai sudrabu, kuru saṇēmis no cilvēkiem, viņiem tas 14 dienās jāatlīdzina un jāsamaksā. Ja viņš to nedara, viņam amatam un rātei jāmaksā pusmarkas sudraba, ko var aizstāt ar 12 markām, un viņam uz pusgadu jāzaudē amata tiesības." (Stieda, Mettig 1896, 301, 9. punkts)

Pēc Reformācijas vairākas amatu šrāgas tika pārrakstītas atbilstoši jaunajiem sociālekonomiskajiem un politiskajiem apstākḷiem, detalizētāk tika izstrādāti profesionālie jautājumi. Naudas sods vairs netika pieprasīts vaska veidā. Reformētajā baznīcā svēto kults vairs nepastāvēja, nebija rituālu, kam 
nepieciešamas sveces. Soda apmaksai vasks tika aizstāts ar naudu. Savukārt soda nomaksa amatam alus veidā atsevišşos gadijjumos saglabājās, piemēram, stiklinieku cunftes 1541. gada šrāgās noteikts, ka: "[..] kungiem trīs mārkas sudraba un amatam vienu mucu alus" (Stieda, Mettig 1896, 286, 14. punkts). Tātad pilsētas rātei bija jāmaksā sods naudā, bet amats saṇēma mucu alus.

Smagākais sods par pārkāpumu bija izslēgšana no amata. Biežāk tas notika, ja amata meistars nekvalitatīvi veica savu darbu, tādējādi apdraudot visas cunftes reputāciju. Piemēram, ja zeltkalis viltoja vai izgatavoja mazvērtīgu priekšmetu (Stieda, Mettig 1896, 300, 6. punkts). "Ja tas notiek otro reizi - jāmaksā sods divas mārkas, ja trešo reizi - meistaru padzen no amata" (Stieda, Mettig 1896, 300-301, 7. punkts). Par atsevišķiem gadijjumiem bija iespējama darbnīcas slēgšana uz laiku.

Sodu veidi un to apjoms šrāgās tika mainīts, pielāgojoties jaunajiem Rīgas pilsētas politiskajiem un sociālekonomiskajiem apstākḷiem. Pirms Reformācijas amatam soda nomaksa par pārkāpumu visbiežāk tika prasīta patēriņa priekšmetos, tomēr šrāgās ir minēti izṇēmumi, kur par kādu konkrētu pārkāpumu arī cunftei sods tika nomaksāts naudā vai naudas ekvivalentam pielīdzināta daudzuma sudrabā. Pēc Reformācijas soda nomaksa patēriña priekšmetu veidā tika aizstāta ar naudu vai sudrabu. Izṇēmums bija zeltkaḷu cunfte, kuras šrāgās nauda vai tai pielīdzināta daudzuma sudraba kā soda nomaksa bijusi vienmēr.

\section{ŠRĀGU TEKSTU LABOJUMI UN KOMENTĀRI}

Mainoties politiskajiem, ekonomiskajiem un sociālajiem apstākḷiem, mainījās arī sabiedrības un šaurāku kopienu ikdienas dzive un vajadzības. Iepriekšējiem apstākḷiem pielāgotie likumi zaudēja savu funkcionalitāti, un tos bija nepieciešams labot vai aizstāt ar jauniem, atbilstošiem jaunajai situācijai. Izmaiņu gaita atspoguḷojas šrāgām pievienotajos vēlāku laiku komentāros un labojumos. Šrāgas ir oficiāli likumi, bet labojumi un komentāri daḷēji norāda uz šrāgu pielāgošanos mainīgajiem sociālekonomiskajiem apstākḷiem, kā arī to, ka teksts ir novecojis un būtu jāpārstrādā atbilstoši esošã laika vajadzībām.

Viens no spilgtākajiem piemēriem ir atslēdznieku, piešu kalēju, stobru kalēju un pulksteņu taisītāju cunftes šrāgas, kas apstiprinātas 1593. gada 29. septembrī (Stieda, Mettig 1896, 448-455). Šrāgās norādīts, ka zellim, kurš tika uzṇemts par jauno meistaru, bija jāuzrāda dzimšanas apliecība (geburtsbrieffe) un mācekḷa apliecība (lehrbrieffe) un jāiegūst pilsētnieka (burgerschafft) tiesības (Stieda, Mettig 1896, 449, 5. punkts). Šrāgām pievienotais komentārs norāda, ka šāds likums nekad nav bijis ievērots. Komentārā teikts: 
"Ja jaunais zellis grib kḷūt par meistaru, viņam ir jādod ungāru Fl [florints]" (Stieda, Mettig 1896, 449). Komentāru aptuvenais tapšanas laiks ir 17. gadsimta vidus (Dunsdorfs, Spekke 1964, 498), kas savukārt sakrīt ar būtisku pārmaiṇu laiku cunftu darbībā.

Citu Rīgas Mazās ğildes amatu šrāgās tik apjomīgu labojumu un komentāru nav. Daži labojumi veikti, piemēram, cepurnieku cunftes 1595. gada šrāgās. Tajās 1638. gadā labota vārdu pareizrakstība - attīstoties vācu valodai, vārdi Dressmeistern un Hollundern aizstāti ar vārdiem Dorfmeister, Holländer (Stieda, Mettig 1896, 352, 28. punkts).

1492. gada drēbnieku šrāgās ir minēts, kā amatam jārīkojas, kad nomirst kāds meistars. Šādā gadījumā līdztekus citiem bēru rituāliem amata meistariem jāapmeklē arī vigīlija (Stieda, Mettig 1896, 483, 17. punkts). Tam, kurš nepiedalās šajos rituālos, jāmaksā viens markpunds vaska. Vēlākajos gados pie šì likuma pierakstīts komentārs latīnu valodā abrogatum jeb atcelts, jo pēc Reformācijas, mainoties reliǵiskajām tradīcijām, mainījās arī bēru rituāli. Minētā soda apmaksa vaska veidā vairs nav nepieciešama, jo luteriskajā baznīcā nav svēto kulta, kura vajadzībām tika patērēts liels vaska daudzums.

Par izmain̄ām pilsētas ekonomikā liecina ādas apstrādātāju cunftes 1397. gada šrāgās izdarītie komentāri. Sākotnēji kā samaksa altāra svecēm tika norādīta puse Rīgas vērdiņa: 1/2 fert. Rig. to unsen lichten to hulpe, bet 1513. gadā pievienots komentārs, kas norāda, ka jāmaksā viens vērdiņš (Stieda, Mettig 1896, 379, 1. punkts). 16. gadsimtā ne tikai Rīgā, bet arī citviet Eiropā bija vērojams cenu kāpums, ko Livonijā radīja tirdzniecība ar Rietumeiropu (Dunsdorfs, Spekke 1964, 516). Piemēram, minētajās šrāgās divu ēru (ore) vietā 1513. gadā tiek prasīti četri šiliņi (veer schillinge) (Stieda, Mettig 1896, 380, 14. punkts).

Šrāgu tekstos ir komentāri, kas norāda, ka likumi papildināti vēl ar kādu citu likumu. Piemēram, zeltkaḷu cunftes 1542. gada šrāgās noteikts: "[..] ja kāda sieva [meistara atraitne] ar kādu zelli būtu vienojusies [par laulībām] un zellis nebūtu amata cienīgs, viṇi abi nevarētu būt amatā. Ja kāda atraitne būtu apprecējusies ar kādu zelli ar amata piekrišanu un viṇi laulībā godīgi nedzīvotu, viṇi abi ir jāizslēdz no amata un viṇi nevar baudīt amata tiesības." (Stieda, Mettig 1896, 304, 18. punkts) Pie šì likuma ir pievienots komentārs: vide unsere additamenta (Stieda, Mettig 1896, 304) - skatīt papildu nosacījumus. Diemžēl šie minētie nosacījumi šrāgās nav norādīti.

Komentāri cunftu šrāgās l,auj uzzināt, kā šie likumi darbojās ikdienā un kāda ir minēto likumu ilgtspējība. Veiktās korekcijas norāda, ka dokumenti ir izmantoti un tie ir attīstījušies atbilstoši pilsētas sociālekonomiskajiem apstākḷiem, - vai nu šrāgas ir laika gaitā papildinātas, vai kāds punkts ir zaudējis savu nozīmi, vairs neatbilst amata prasībām, un šrāgas ir pārrakstītas. 


\section{SECINĀJUMI}

Rīgas Mazās gíldes cunftu darbību stingri reglamentēja gan organizācijas, gan pilsētas sabiedrības likumi. Cunftu šrāgu virsmērḳis bija amatnieku profesionālās darbības regulēšana, taču tās kontrolēja arī sociālos un kultūras faktorus. Apkopojot avotu materiālu par pārkāpumiem un sodu nomaksām cunftu statūtos no 14. gadsimta otrās puses līdz 17. gadsimta sākumam, jāsecina, ka šrāgas norāda uz amatnieku sabiedrības profesionālajām un sociālajām vērtībām.

Šrāgās minētie sodāmie pārkāpumi ietver profesionālos, sociālos un religiskos jautājumus. Šrāgas tika izstrādātas, sargājot kopienas mērḳus un intereses, tādējādi katrs likuma pārkāpums bija to apdraudējums. Soda nomaksa mainījās atbilstoši vēsturiskajam kontekstam. Laikā pirms Reformācijas (no 14. gadsimta otrās puses līdz 16. gadsimta sākumam) šrāgās soda nomaksa galvenokārt tika pieprasīta patēriṇa priekšmetu veidā - vaskā un alū. Vasks bija viena no pieprasītākajām un vērtīgākajām precēm viduslaikos. İpaši liels vaska patērinš̌ bija reliǵgiskajos rituālos - altāru svecēm. To izmantoja arī amata sanāksmēs telpu apgaismošanai. Alu galvenokārt izmantoja cunftes drunke laikā. Alu un vasku kā soda nomaksu san̄ēma amats, soda nomaksu naudā - Rīgas pilsētas rāte. Savukārt pēc Reformācijas par galveno soda nomaksas veidu kḷuva nauda, kas saistīts ar pilsētas preču - naudas attiecību pieaugumu. Zeltkal̦iem amata specifikas dēl, soda nomaksa nemainīgi bija noteikta naudā vai ar naudas ekvivalentu sudrabā. Šrāgās norādītais bargākais sods par pārkāpumu bija amatnieka izslēgšana no cunftes. Viduslaiku strukturētajā sabiedrībā šāds sods apdraudēja visu meistara ǵimeni. Šādā gadījumā tika zaudētas cunftes nodrošinātās profesionālās, sociālās un reliǵiskās garantijas.

Vēlākajos laikos šrāgās veiktās korekcijas un komentāri norāda uz šrāgu izmantojumu de facto un likumu attīstību atbilstoši pilsētas politiskajiem un sociālekonomiskajiem apstākḷiem. Šrāgās minēto pārkāpumu un sodu nomaksas veidu dinamika liecina par politisko, ekonomisko, sociālo un kultūras faktoru ietekmi gan cunftu darbībā, gan mērḳu un ideālu maiṇu. Lai iegūtu aptverošāku priekšstatu par šrāgu darbību praksē, ir nepieciešams salīdzināt šrāgas un to komentārus ar citiem dokumentiem - amatu grāmatām, tiesu protokoliem un citiem.

\section{IZMANTOTIE AVOTI UN LITERATŪRA AVOTI}

Mettig, C., 1890. Das älteste Amtsbuch der Schmiede zu Riga und der Schragen derselben von 1578. Riga: Druck von W. F. Häcker.

Napiersky, J. G. L. (Hrsg.), 1876. Die Quellen des Rigischen Stadtrechts bis zum Jahr 1673. Riga: Verlag von J. Deubner. 
Rīgas pilsētas tipogrāfa Nikolausa Mollīna 1593. gadā iespiestais Karaḷa pilsētas Rīgas Vidzemē - godātās rātes atjaunotais kāzu un apǵērbu nolikums. Kvaskova, V. (tulk., koment.), 2013. [Sigulda]

Stieda, W., Mettig, C., 1896. Schragen der Gilden und Aemter der Stadt Riga bis 1621. Riga: Buchdruckerei von W. F. Häcker.

\section{LITERATŪRA}

Berga, T., 2003. Rìgas monētu kolekcija Rïgas vēstures un kuǵniecības muzejā, Livonijas periods (13.-16. gs.). Rīga: Latvijas vēstures institūta apgāds, 5-14.

Brunstermann, F., 1902. Die Geschichte der Kleinen oder St. Johannis Gilde in Wort und Bild (zum Jubiläumsjahr 1901). Riga: Lithographie und Buchdruckerei Alexander Stahl, Wallstr. Nr. 29.

Dunsdorfs, E., Spekke, A., 1964. Latvijas vēsture 1500-1600. Stokholma: Daugava, 444-566.

Fišere, J., 2020. Rīgas Mazās ǵildes cunftu tradīciju dinamika, 14. gadsimta otrā puse līdz 16. gadsimta beigas. Maǵistra darbs. LU VFF Vēstures un arheolog̣ijas nodaḷa.

Heusinger, S., 2009. Die Zunft im Mittelalter. Zur Verflechtung von Politik, Wirtschaft und Gesellschaft in Straßburg. Stuttgart: Franz Steiner Verlag.

Heusinger, S., 2010. Von "Antwerk" bis "Zunft" Methodische Überlegungen zu den Zünften im Mittelalter. Zeitschrift Für Historische Forschung.

Isenmann, E., 2014. Die Deutsche Stadt im Mittelalter, 1150-1550 Stadtgestalt, Recht, Verfassung, Stadtregiment, Kirche, Gesellschaft, Wirtschaft. Wien; Köln; Weimar: Böhlau Verlag GmbH \& Cie.

Ojala, M., 2012. Widows' opportunities to Continue Craft Trade in Northern Baltic Cities During the $15^{\text {th }}$ and $16^{\text {th }}$ Centuries. Andersen (ed.). Widows' Opportunity Law and Marriage in Medieval and Early Modern Times. Copenhagen: DJøF Publishing, 199-220.

Ojala, M., 2013. Religious Participation in the Craft Ordinances in the Baltic Sea Region. Sari Katajala-Peltomaa, Ville Vuolanto (eds.). Religious Participation in Ancient and Medieval Societies Rituals, Interaction and Identity. Roma, 79-90.

Taube, M., 1960. Greznības noliegums Rīgā XVI un XVII gadsimtā. Fundamentālās bibliotēkas raksti, 1. sēj. Rīga: Latvijas PSR Zinātṇu akadēmijas izdevniecība, 287-308.

Taube, M., 1980. Rigas latviešu tirdzniecỉbas paligamati 17.-18. gs. Rīga: Zinātne.

Zeida, Ā., 1967. Algotais darbaspēks Rīgas cunftu amatniecībā feodālisma laikā (14. gs. otrā puse - 19. gs. vidus). Rìgas vēstures un kuğniecības muzeja arhīvs. ZA, 1333. un 1370. lieta.

Zeids, T. (red.), 1978. Feodālā Rìga. Rīga: Zinātne, 12-220.

Zemzaris, J., 1981. Mērs un svars Latvijā 13.-19. gs. Rīga: Zinātne.

\section{ATSAUCES UN PIEZİMES}

${ }^{1} 1$ lispunts $=8,376$ kg. Zemzaris, J., 1981. Mērs un svars Latvijā 13.-19. gs. Rīga: Zinātne, 52.

${ }^{2}$ Mucas tilpums - 118,6-121,5 1. Zemzaris, J., 1981. Mērs un svars Latvijā 13.-19. gs. Rīga: Zinātne, 122.

${ }^{3} 1$ markas mārciņa - 415,68 g. Zemzaris, J., 1981. Mērs un svars Latvijā 13.-19. gs. Rīga: Zinātne, 160. 


\title{
ANTHROPOLOGY OF MISCONDUCT AND PUNISHMENT OF RIGA ARTISANS OF THE SMALL GUILD, SECOND HALF OF $14^{\text {TH }}$ CENTURY - BEGINNING OF $17^{\text {TH }}$ CENTURY: EXAMPLE OF STATUTES OF ARTISANS
}

\author{
JUSTITNE FIŠERE \\ Mg. hist. \\ E-mail: fiserejustine@gmail.com
}

\begin{abstract}
The activities of the Riga Artisans (Zunft) of the Small Guild were regulated by the Statutes (Schragen) of Artisan Guild. Artisan guilds (Zunft) were organizations whose main purpose was to define the professional activities of craftsman, they also partly regulated social and religious issues. The Statutes of Artisan Guilds (Schragen) included the interests and objectives of the community, and each committed misconduct or breach of the law was a threat to them. Breaches of the Statutes were punishable, depending on the gravity of the infringement. As political, economic, social and religious factors of the City of Riga changed in the wake of new circumstances, laws and sanctions adopted by the Artisan Guilds also changed. The aim of the study is to provide an insight into the problems pertaining to the anthropology of misconduct and punishment of the Small Guild of Riga by analysing the Statutes of Artisan Guild approved by the city court.
\end{abstract}

Keywords: Small Guild of Riga, artisans, Statutes, Statutes of Office, Riga city, medieval city craft trade.

\section{SUMMARY}

When craftsmen arrived to live in Riga at the beginning of the $13^{\text {th }}$ century, they were already familiar with the forms of craft organizations in German lands. Forming an artisan guild (Zunft) in Riga, craftsmen took over the Statutes (Schragen) from other German cities, which were formed according to the socio-economic conditions of those cities. Over time, the Statutes (Schragen) were redesigned in accordance with the political, economic, social and cultural factors of the city of Riga. 
The Small Guild of Riga Artisans (Zunft) was strictly regulated, subject to all the laws of the city, as well as the statutes of craftsmen organizations. The Statutes (Schragen) determined the professional, social and other issues relevant to the artisans. Membership of the Artisan Guild established a status in society, consequently, an artisan had to be professionally worthy of this membership, both in the performance of his work according to the established performance standards and in compliance with the social standards set by Artisan Guild. The requirements and stipulations included the entire family of the craftsman, as well as the apprentices and fellows. In addition to the limits and laws imposed by the office, there were different professional and social guarantees for Artisan Guild members.

Artisan guilds as professional organizations mainly created their laws for regulating professional activity. In addition to the law stipulating the professional activities, laws on religious and social matters pertaining to the craftsmen were included in the Statutes (Schragen) of artisan guilds. The Statutes (Schragen) were designed to protect the goals and interests of the community, and each misconduct was a threat to them.

In the event of breach of the law, the punishments were imposed according to the offence in line with the Statutes (Schragen). Before the Reformation, the misconduct directed against the office due to breach of professional or moral standards of the Artisan Guild was subjected to a form of punishment in consumer products, either in wax or beer. The wax was mainly intended for altar candles at Artisan Guild, which reflected the medieval Christian vision of the world, while the beer was intended for the communal Artisan Guild drinking - drunke. After the Reformation, the main form of payment of the penalty became money, which was due to increased goods-cash relationships in the city. In the case of the goldsmiths of the Artisan Guild, as a consequence of their craft, the payment of the fine in money or the weight equivalent in silver had always been in order. For the Riga City Council, the fine was always paid with money. The most serious punishment for the misconduct was revoking the membership of the Guild, and thereby the craftsman lost the professional and social guarantees provided by the organization.

As the political and socio-economic conditions in the city changed, the Statutes of Artisan Guild became outdated and needed adjustments or even remaking. Several of the Statutes (Schragen) of the Artisans of the Small Guild of Riga in later times have been improved with comments. Those show how de iure worked de facto in the changing socio-economic conditions of the city. 


\title{
PADOMJU LATVIJAS RŪPNIECĪBAS ATJAUNOŠANA UN ATTĪSTĪBA 20. GADSIMTA 40.-50. GADOS: BŪVMATERIĀLU RAŽOŠANAS NOZARES PIEMËRS
}

\author{
ALEKSANDRS PETROVS \\ Mg. hist., LNA Latvijas Valsts arhīva dokumentu saglabāšanas \\ nodaḷas galvenais fondu glabātājs \\ E-pasts: aleksandrs.petrovs@arhivi.gov.Iv
}

\begin{abstract}
ANOTĀCIJA
Raksta mērḳis ir sniegt ieskatu galvenajās Latvijas PSR rūpniecības attīstības iezīmēs un problēmās pēckara gados, ilustrējot to ar vienas no republikas rūpniecības "šaurajām vietām" - būvmateriālu ražošanas nozares - piemēru.

Pētījumā, kas kḷuva par pamatu šīs publikācijas tapšanai, balstoties uz arhīva materiāliem, tika apzināta Latvijas PSR tautsaimniecības struktūra un tās atjaunošanas procesi no Otrā pasaules kara beigām līdz 1953. gadam, šim mērḳim padziḷināti izpētot vienu no tās nozarēm - būvmateriālu rūpniecību, īpašu uzmanību pievēršot ražošanas procesam, ražotajai produkcijai un galvenajiem darbības rādītājiem.

Pētījuma rezultāti parāda - lai gan būvmateriālu ražošanai bija piešḳirta stratēgiskā nozīme un tā bija strauji jāattīsta, realitātē tās stāvoklis pētāmajā laika posmā bija prioritārai tautsaimniecības nozarei neatbilstošs.
\end{abstract}

Atslēgas vārdi: Latvijas PSR, tautsaimniecība, ekonomika, rūpniecība, ražošana, būvmateriāli.

\section{IEVADS}

Tautsaimniecībai, neatnemamai jebkuras valsts un tautas vēstures daḷai, diemžēl tradicionāli nav pievērsta tik liela vēsturnieku uzmanība kā, piemēram, politiskām un militārām pagātnes norisēm. Daḷēji to varētu izskaidrot ar faktu, ka vēl salīdzinoši nesen tautsaimniecības vēsture vairāk nodarbināja ekonomikas (vai politiskās ekonomijas) pētniekus un bija 
vinu kompetences lokā. Tomēr mūsdienās līdz ar visas tautsaimniecības struktūras principiālām izmaiṇām kādreizējie saimniekošanas principi un ekonomiskā politika kopumā organiski kḷuvuši par vēsturnieku izpētes lauku. Turklāt nozīmīgu devumu saimniecības vēstures izpēte var sniegt arī mūsu valsts sociālās vēstures attīstībā, jo pievērsties lauksaimniecībai un rūpniecībai, iedziḷinoties procesos, kas notikuši šajās jomās, nozīmē ielūkoties sfērā, kurā atšķirībā no militārām lietām un arī politikas bija nodarbināts absolūtais iedzīvotāju vairākums jebkurā valstī un politiskajā režīmā. No otras puses, tautsaimniecība ir joma, kas nav atdalāma no politikas. Kā ir teikusi Latvijas eksprezidente Vaira Vỉke-Freiberga: "Ekonomiskie apstākḷi vienmēr ir bijuši ciešā mijiedarbē ar politisko vidi un sabiedrības struktūru, tādēḷ Latvijas un tās iedzīvotāju saimnieciskā situācija un iespējas ir cieši saaugušas ar latviešu tautas likteniiem un vēsturisko attīstību" (Krūmiņš 2017). Šim apgalvojumam var piekrist, jo, neñemot vērā ekonomisko faktoru, nekādus fundamentālus politiskus mērķus nevar ne izvirzìt, ne panākt, ne arī saprast, tādēl ka tieši ekonomiskā bāze nosaka, cik lielā mērā jebkādi nopietni politiskie mērḳi ir îstenojami. Šajā ziņā kā ekonomika un politika, kā saimniecība un sabiedrība, tā arī politiskā, saimnieciskā un sociālā vēsture ir vienotas un nav mehāniski atdalāmas viena no otras.

Otrā pasaules kara, karadarbības un nacistu īstenotās saimnieciskās politikas rezultātā Latvijas teritorijas saimnieciskais potenciāls bija ievērojami cietis, kas lielākoties ir saistīts ar vietējā darbaspēka zaudējumiem sakarā ar represijām, mobilizāciju un piespiedu vervēšanu darbiem Vācijā (nemaz nerunājot par to, ka esošie un vēl strādājošie rūpnieciskie uzṇēmumi, kā arī lauksaimniecība darbojās Vācijas un tās karaspēka, nevis vietējo vajadzību apmierināšanai), taču par smagāko triecienu kḷuva vācu okupantu mēginājumi izmantot t. s. "izdedzinātās zemes taktiku". No Latvijas teritorijas atkāpjoties, visas iespējamās vērtības - izejvielas, gatavo produkciju, mašīnas un iekārtas - nacisti centās aizsūtīt uz Vāciju, bet tas, kas nebija paṇemams līdzi, pēc iespējas tika iznīcināts - piemēram, tika dalı̄eji izdemolēta Ķeguma HES un citas (kopā 52) spēkstacijas, 5790 rūpnieciskie uzṇēmumi un pat to tukšie korpusi, dzelzceḷ̆š, tilti un citi infrastruktūras objekti (Aizsilnieks 1968, 950; Krastiņ̌ 2018, 159).

Tāpat kauju un bombardēšanas rezultātā manāmi samazinājās Latvijas lielāko pilsētu dzīvojamais fonds. Ja Rīgā situācija bija vēl kaut cik ciešama - tā neatgriezeniski zaudēja "tikai" $19 \%$ no pirmskara valstij piederošā dzīvojamā fonda (Cīña 1945, 91), piemēram, Liepāja zaudēja 41,6 \% un Jelgava - $91 \%$ apdzīvojamās platības (Komunists 1946, 214), neskaitot nosaciti dzīvošanai derīgās ēkas ar izsistiem logiem, cauriem jumtiem un bojātām komunikācijām. Desmiti, ja ne simti tūkstoši cilvēku pārdzivoja karu un nacistu okupāciju, bet zaudēja savu mājokli. 
Pēc Latvijas PSR ĀRK aplēsēm, kopumā republikai tika nodarīti zaudējumi aptuveni 20 mljrd. rubḷu apmērā 1941. gada cenu izteiksmē; lai gan mūsdienu pētnieki pārsvarā nepiekrīt šim skaitlim, pieminot arī citu - 660 milj. ASV dolāru (Bleiere et al. 2005, 324). Lai kā būtu, neviens neapstrīd faktu, ka, lai gan Latvijas teritorijā kara zaudējumi bija nesalīdzināmi mazāki nekā, piemēram, blakus esošajās Baltkrievijas vai Ukrainas PSR, tomēr arī ievērojama daļa Latvijas pilsētu un ciemu māju, uzñēmumu, tiltu, elektrostaciju u. c. infrastruktūras objektu kara gaitā tika pārvērsti drupās.

Lai uzsāktu tautsaimniecības, komunālās un arī militārās saimniecības pēckara atjaunošanas procesu, padomju varai bija vitāli svarīgi pēc iespējas ātrāk "ievadīt pareizās sliedēs" būvmateriālu ražošanu - uzdevums, kurš, kā izrādās, nemaz nebija tik viegls, lai gan jau pirms kara Latvijas Republikā šì nozare bija diezgan labi attīstìta - 1939. gadā Latvijā tika saražots 123 milj. kieǵelu un $164000 \mathrm{t}$ cementa (Latvijas PSR statistikas tabulas 1940, 141), bet tādas ražotnes kā "Rīgas ǵipsis", Bolderājas būvkeramikas fabrika un cementa fabrika Brocēnos skaitijāas savam laikam visai modernas un augsti mehanizētas - to, bez šaubām, labi apzinājās arī vācieši, jo, atbrīvojot Latvijas teritoriju no Vācijas karaspēka, izrādījās, ka šo fabriku tehnologiskais aprīkojums vai nu pazuda (Cīna 1946, 228), vai tika apzināti sabojāts (Eiduks 1962, 197-198).

Būvmateriālu rūpniecības atjaunošana tika deklarēta par visaugstāko prioritāti līdzās energoapgādes atjaunošanai un kurināmā ražošanai - tā bija oficiāli ierakstīta Tautsaimniecības atjaunošanas un attīstības piecgades plāna likumā, atspoguḷojās vietējā mēroga padomju valdības un Komunistiskās partijas amatpersonu runās un rīkojumos, preses materiālos, galu galā, arī veselais saprāts pasaka priekšā, ka bez būvmateriāliem nekāda atjaunošana notikt vienkārši nevar.

Diemžēl no saimnieciskās vēstures skatpunkta, pēckara desmitgades periods Latvijā ir pētīts ievērojami mazāk nekā vēlākie: detalizētu ziņu par tajā notiekošajiem procesiem, saražoto produkciju un uzṇēmumiem ir mazāk kā padomju, tā arī mūsdienu literatūrā, lai gan, pētot tieši šo posmu, var iedziḷināties problēmās, kuras piedzīvoja padomju sistēma savas nostiprināšanās periodā Latvijas teritorijā, saprast, kādi faktori veicināja Latvijas sovjetizāciju un industrializāciju, kādi - kavēja. Līdzšinējā historiogrāfija par Staliina laika rūpniecību Latvijā un sevišķi par būvmateriālu rūpniecību (liekas, atsevišḳu vēsturnieku darbu par to vispār nav) nav atzīstama par izsmeḷošu - kā viens no nedaudziem, ja ne vienīgais darbs, kurā tika mēǵināts konceptuāli apskatīt Latvijas teritorijas industrializācijas problēmas un izvērtēt tās sekas ilgtermiņā, ir minama Dr. hist. Irēnas Šneideres 1989. gada monogrāfija. Tomēr kopumā līdz šim un joprojām pētnieki, apskatot attiecīgo jautājumu, ne tikai nefokusējas uz saimniecisko aspektu, tā vietā izceḷot iepriekš minēto procesu politisko dimensiju, 
bet arī lielā mērā paši atrodas politiskās konjunktūras ietekmē - kā padomju darbos Latvijas PSR sociālistiskā industrializācija tika vērtēta viennozīmīgi pozitīvi jebkurā aspektā, bet netika plaši atzītas un pietiekami analizētas kḷūdas, nepilnības un nejēdzības, kas pavadīja šo procesu, tā arī lielākajā daḷā trimdas un mūsdienu literatūras sociālistiskā industrializācija ir aprakstīta pavirši un tās kā viennozīmīga l,aunuma vērtējums tajā ir gandrīz vai aksiomātisks.

Par pamata avotiem dotās tēmas izpētei var kalpot tādi LNA Latvijas Valsts arhīvā glabājamie dokumenti kā LK(b)P/LKP CK ${ }^{1}$ lēmumi un sarakste par būvniecību un būvmateriālu rūpniecību (PA-101. f.), LPSR Būvmateriālu rūpniecības (1398. f.) un Vietējās rūpniecības (378. f.) tautas ko-

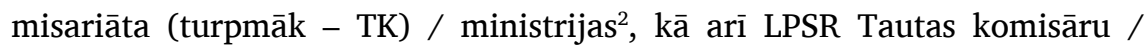
Ministru padomes (270. f.) un Valsts plāna komitejas (693. f.) dokumenti, konkrēto uzṇēmumu LKP pirmorganizācijas sapulču protokoli, kā arī Krievijas arhīvos glabātie dokumenti, kas attiecas uz PSRS Būvmateriālu rūpniecības TK/ministriju (RGAE, 8248. f.) un tās glavkiem - galvenajām pārvaldēm (piem., RGAE, 8245. f. - Glavzapadcement jeb Rietumu rajonu cementa rūpniecības galvenā pārvalde). Svarīgs sekundārs avots ir arī tā laika prese - nenoliedzot faktu, ka tajā sniegtā informācija neiztika bez zināmas tendenciozitātes un koncentrējās uz pozitīvo aspektu izcelšanu (kas izriet no preses kā propagandas līdzekḷa darbības mērḳa), kā arī saprotamu iemeslu dēḷ kritika tajā nevarēja būt vērsta pret politisko un saimniecisko valsts kursu, tomēr noteiktas problēmas, ar kurām saskārās šo izdevumu mērḳauditorija - parastie strādnieki, zemnieki un kalpotāji, tajā skaitā būvmateriālu ražošanas nozarē nodarbinātie -, ir konstatējamas un diezgan bieži izceltas. Visai konkrētu gadījumu apraksts (par vienā vai otrā uzñēmumā veiktajiem paplašināšanas vai rekonstrukcijas darbiem, darbinieku disciplīnas pārkāpumiem, bet it īpaši par nekvalitatīvas produkcijas izlaišanu un augsto brāķa īpatsvaru, kuru daudzkārt aprakstīja un nosodīja daudz bargāk tieši presē, nevis arhīvā glabājamos dokumentos) savukārt liecina par to, ka presē sniegtajai informācijai piemita ne tikai virspusīgs un propagandisks raksturs. Uz presē publicētiem datiem, protams, nevar pilnīgi paḷauties, tomēr tie ir izmantojami atsevišksu aspektu dziḷākai izpētei, kā arī salīdzinošai analīzei, savstarpēji pārbaudot gan dažādos rakstos un izdevumos, gan arhīva materiālos sniegto informāciju.

\section{BŪVMATERIĀLU RAŽOŠANAS NOZARES STRUKTŪRA UN SVARĪGĀKIE UZṆĒMUMI}

Pēc nacistiskās Vācijas karaspēka padzī̌sanas no Latvijas teritorijas visa tautsaimniecība atgriezās padomju institūciju pārvaldē. Tāpat kā citu 
nozaru uzṇēmumi, arī būvmateriālu rūpnīcas un fabrikas tika sadalītas pēc to lieluma un svarīguma:

1. vissavienïbas nozīmes (PSRS Būvmateriālu rūpniecības TK / ministrijas tiešā pakḷautībā);

2. republikāniskajos (pakḷauti Latvijas PSR Būvmateriālu rūpniecības TK / ministrijai);

3. vietējos, kuri nonāca Latvijas PSR Vietējās rūpniecības TK / ministrijas pakḷautībā.

Pirmajai kategorijai atbilstošo būvmateriālu uzņēmumu Latvijas PSR uzreiz pēc kara nebija, tomēr 1951. gadā atjaunojusies un strauji attīstījusies republikas cementa ražošana (Rīgas un Brocēnu cementa rūpnīcā) saskaṇā ar PSRS AP Prezidija lēmumu pilnībā nonāca vissavienības orgāna - PSRS Būvmateriālu rūpniecības ministrijas Rietumu rajonu cementa rūpniecības galvenās pārvaldes (Glavzapadcement) - pakḷautībā (LNA-LVA, 1398-1-159, 158).

1945. gada 31. martā dibinātā Celtniecības un būvmateriālu rūpniecības TK sistēmā pēc kara nonāca 49 būvmateriālu ražošanas uzṇēmumi (LNALVA, 1398-1-145, 58-59), no kuriem tikai piecos bija daḷeji atjaunota ražošana (LNA-LVA, PA-101-6-23, 122), savukārt 1945. gada beigās strādāja jau 30 uzñēmumi (LNA-LVA, 1398-1-145, 58-59), bet 1948. gadā - gandrīz visi, izņemot Brocēnu šifera fabriku, Brocēnu cementa fabrikas trešo kārtu un dažus ḳiegeẹnīcu cehus (LNA-LVA, 1398-1-190, 3). 1946. gadā iepriekš minēto TK sadalīja divās atsevišķās ministrijās un Latvijas PSR būvmateriālu lielražošanu pārṇēma Latvijas PSR Būvmateriālu rūpniecības ministrija, savukārt sīkie lauku kalı̣,u un ķiegeḷcepḷi nonāca Vietējās rūpniecības ministrijas pārvaldībā, kur tos apvienoja rūpkombinātos. Lielākie un svarīgākie būvmateriālu uzñēmumi pēc kara bija: Kalnciema un Brocēnu kombināts (attiecīgi ḳieǵeḷu un cementa ražošana), "Riǵipsis" (sausā apmetuma ražošana), "Segums" (jumtu papes ražošana), kā arī "Sarkandaugava" (stikla ražošana), turklāt jau 1946. gadā tika plānota pirmās jaunās rūpnīcas izbūve Bolderājā, kur no vietējām smiltīm ievērojamā daudzumā ražotu silikātkiegẹelus, - to pabeidza 1952. gada vidū.

Bez iepriekš minētajām uzṇēmumu grupām Latvijas teritorijā funkcionēja arī atsevišķas būvmateriālu ražotnes, kas nebija pakḷautas ne LPSR vai PSRS Būvmateriālu, ne Vietējās rūpniecības ministrijai. Piemēram, viena no 60.-70. gados lielākajām ḳieǵeḷu un būvkeramikas rūpnīcām "Spartaks" līdz 1948. gadam bija Kara jūrniecības celtniecības pārvaldes Nr. 5 uzṇēmums (Zujeva) un pārsvarā izpildīja kara flotes pasūtijumus - flotes bāzes celtniecība Daugavgrīvā, Bolderājas Ziemas ostas akvatorijas gultnes padziḷināšana u. tml. - un arī piedalījās uzspridzinātās Daugavas krastmalas atjaunošanā (LNA-LVA, PA-101-11-82, 1-4), savukārt Krustpils kieǵeḷu rūpnīca, lai gan institucionāli bija pakḷauta Būvmateriālu rūpniecības ministrijai, tika 
iznomāta Latvijas dzelzceḷa Militārās celtniecības darbu pārvaldei (LNALVA, PA-101-9-82, 80). Daži ar būvniecību saistītie uzņēmumi, galvenokārt būvdetalı un būvkonstrukciju ražotnes, atradās Dzivokḷu un civilās celtniecības ministrijas, kā arī Komunālās saimniecības ministrijas sistēmā, savukārt būvmateriālus šì jēdziena plašā nozīmē ražoja arī Meža rūpniecības ministrijas (lietkoksni), PSRS Ķīmiskās rūpniecības ministrijas Ķīmiskās rūpniecības GP (silikātus) u. c. uzñēmumi. Prakse parādīja, ka tāda institucionāla sadrumstalotība îsti nenāca nozarei ${ }^{3}$ par labu, dažkārt provocējot interešu konfliktus dažādu resoru cinņā par resursiem ${ }^{4}$ apstākḷ,os, kad būtu log̣iskāk tos koncentrēt vienuviet.

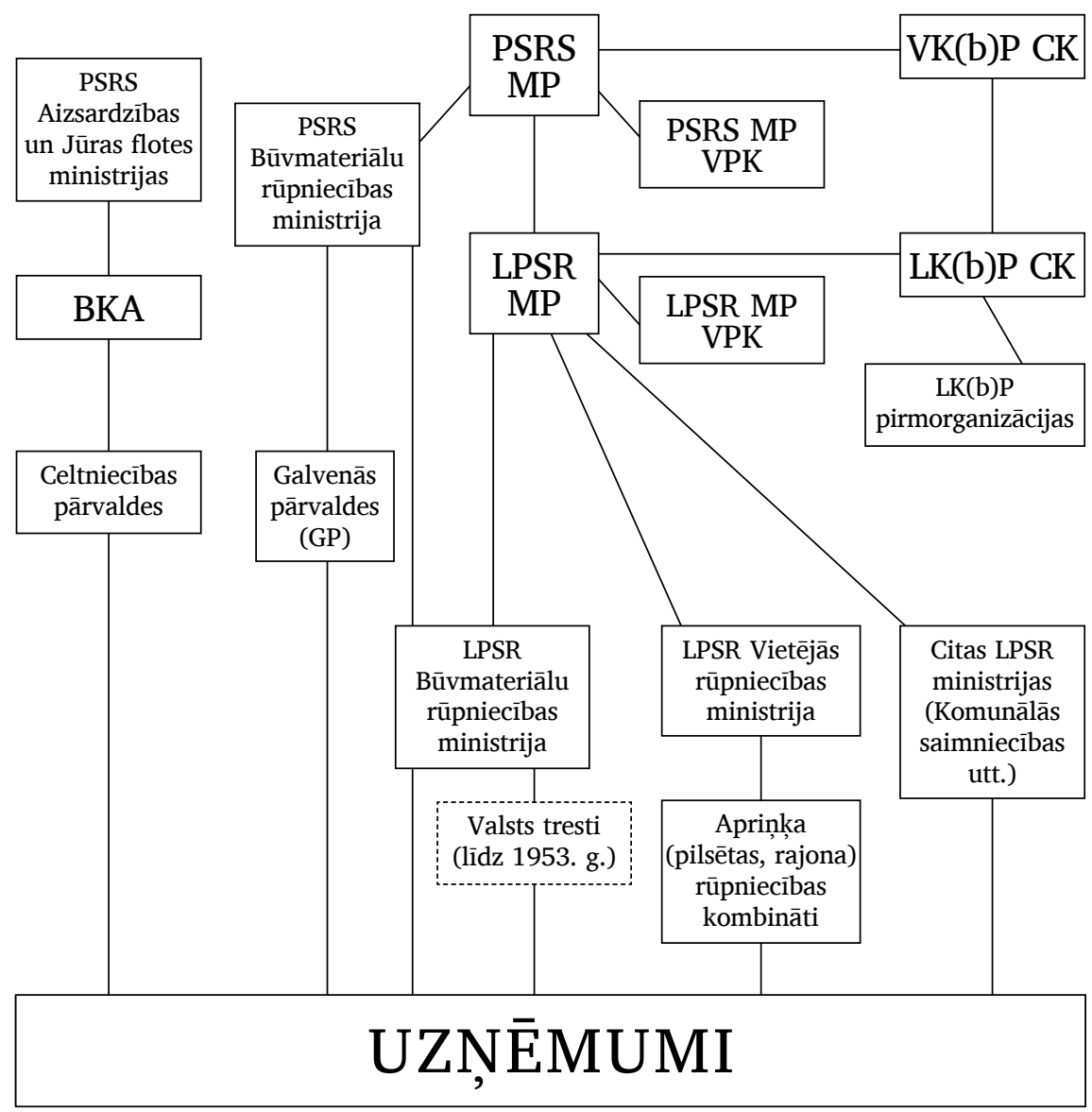

1. attēls. Latvijas PSR būvmateriālu ražošanas uzṇēmumu nosacītā pārvaldes shēma (20. gs. 50. g. pirmā puse). Autors: A. Petrovs

Figure 1. Conventional scheme of the institutional structure of the Latvian SSR building material enterprises (the first half of the 1950s). Author: A. Petrovs 


\section{GALVENIE DARBĪBAS RĀDĪTĀJI}

Uzreiz pēc Otrā pasaules kara būvmateriālu ražošana Latvijas teritorijā maz atgādināja 1939. vai 1940. gada rūpnieciskās ražošanas līmeni, bet vairāk līdzinājās 18. gadsimta situācijai pirms Industriālās revolūcijas. Daudzi avoti liecina par smagiem nozarei nodarītajiem zaudējumiem (LNA-LVA, 1398-1-144, 8; LNA-LVA, 1398-1-146, 25; u. c.). Veicot pēckara revīziju, tika konstatēts, ka no 56 uzṇēmumiem, kas 1941. gadā bija reǵistrēti Būvmateriālu rūpniecības TK sistēmā, kara gaitā cietuši pilnīgi visi, turklāt 100 \% ražošanas jaudas zaudējumu esot cietuši 50 uzñēmumi, $95 \%$ - viens uzṇēmums, $80 \%$ - viens, $50 \%$ - trīs un $20 \%$ - viens uzṇēmums (LNA-LVA, 1398-1-191, 12-14, 39-40), ${ }^{5}$ turklāt lielu satricinājumu piedzīvoja ne tikai ražošanas materiāltehniskā bāze, bet arī darba kultūra, disciplīna un ražošanas tradīcijas. Apstākḷos, kad darbaspēka trūkuma dēl ražošanas procesos tika iesaistīti nekad līdz šim ar to nesaistīti cilvēki, kadru politika ieguva arī apmācīšanas un audzināšanas darba iezīmes turklāt tas nekādā ziṇā nebija vieglāks par sapostīto ēku vai ražošanas iekārtu atjaunošanu.

Pirmajos pēckara gados padomju republikām visādā ziṇā bija jāpaḷaujas uz vietējiem resursiem. Ražošanas līdzekḷu kontekstā tas nozīmēja visa iespējamā pēc kara palikušā aprīkojuma un inventāra remontu un pārtaisīšanu ar vienīgo mērḳi - nodrošināt to ekspluatāciju, lai gan par primāro ražošanas metodi šajā laikā nenoliedzami kḷuva cilvēku roku darbs. Pirmo impulsu normāla, savam laikmetam atbilstoša ražošanas procesa atjaunošanai deva no uzvarētās Vācijas atvestās iekārtas, bet to, protams, ne tuvu nepietika visiem sapostītajiem uzn̄ēmumiem.

1949. gadā aizsākās Kalnciema kombināta rekonstrukcija ar mērḳi nodrošināt tajā ḳieǵeḷu ražošanu visu gadu (iepriekš tas bija sezonāls darbs, bet ārpus sezonas būvkeramikas uzṇēmumi ražoja dažādus blakusproduktus, piemēram, māla traukus). Tolaik kombināts arī pirmo reizi saṇēma padomju ražojuma ražošanas līdzekḷus - spiednes, ekskavatorus utt. Tādējādi 1950. gadā būvmateriālu rūpniecības kopprodukts Latvijas PSR, salīdzinot ar 1946. gada stāvokli, pieauga vien 1,85 reizes un tikko sasniedza 1940. gada līmeni (salīdzinājumam, elektroenerğētikas kopprodukts 1950. gadā pārsniedza 1940. gada līmeni 2,5 reizes, bet mašīnbūves un metālapstrādes - 11,5 reizes), kas liecina par ārkārtīgi lēnu nozares atkopšanās tempu, pat salīdzinot ar neprioritārām vieglās rūpniecības nozarēm.

Zināmā mērā situāciju paglāba Bolderājas silikātḳieǵeḷu rūpnīcas nodošana ekspluatācijā 1952. gada jūnijā - tikai pēc tam, 1953. gadā, Latvijas PSR izdevās sasniegt saražoto ķieǵeḷu (neapšaubāmi, 20. gadsimta pirmās puses vissvarīgākā būvmateriāla Latvijas teritorijā) pirmskara ražošanas apjomu. 
1. tabula. Galveno Latvijas PSR rūpniecības nozaru kopprodukcijas izaugsme 1946.-1950. g., salïdzinot ar 1940. g.

Autors: A. Drīzulis (ar A. Petrova papildinājumu)

Table 1. The growth of gross production of the Latvian SSR main industry sectors in 1946-1950 (compared with 1940).

Author: A. Drīzulis (with addendum by A. Petrovs)

\begin{tabular}{|l|c|c|c|}
\hline \multirow{2}{*}{} & \multicolumn{2}{|c|}{$\begin{array}{c}\text { Kopprodukcija } \\
\text { (1940. g. 100) }\end{array}$} & $\begin{array}{c}\text { Dinamikas } \\
\text { indekss } \\
\text { (1946.-1950. g.) }\end{array}$ \\
\cline { 2 - 3 } & 1946. g. & 1950. g. & \\
\hline Mašīnbūve un metālapstrāde & 266 & 1157 & 4,35 \\
\hline Vieglā rūpniecība & 54 & 205 & 3,79 \\
\hline Elektroenerğētika & 100 & 236 & 2,36 \\
\hline Kurināmā rūpniecība & 172 & 362 & 2,10 \\
\hline Būvmateriālu rūpniecība & 66 & 122 & 1,85 \\
\hline \multicolumn{1}{|c|}{ Visa rūpniecība } & $\mathbf{8 5}$ & 303 & 3,56 \\
\hline
\end{tabular}

Avots: LNA-LVA, 1398-1-146, 3; LNA-LVA, 1398-1-150, 44; LNA-LVA, 1398-1-157, 2.; Drīzulis 1986, 32

Daudz raitāk gāja ar tāda neaizvietojama būvmateriāla ražošanu kā logu stikls, kura galvenais ražotājs Latvijas teritorijā bija fabrika "Sarkandaugava", kas savu zvaigžņu stundu piedzīvoja jau 1946.-1947. g., sasniedzot virkni PSRS un pat pasaules rekordu, kāpinot vienas savas Furko mašīnas izstrādi no 60 augstas kvalitātes stikla lentes metriem stundā līdz $97 \mathrm{~m} / \mathrm{h}$ 1946. gada septembrī un 146 m/h 1947. gadā, kamēr līdzšinējais amerikāņu stiklinieku rekords esot bijis 90 m/h (Pionieris 1946, 33; Brīvā Venta 1948, 86; Padomju Jaunatne 1947, 23). Šis sasniegums tika atspoguḷots pat tā laika trimdas presē, turklāt bez tai parasti piemītošās ironijas un izsmiekla (Latviešu Ziṇas 1946, 101), bet dzimtenē tam tika veltīti literārie darbi (Karogs 1946, 11/12). Turklāt rekorda autori - fabrikas galvenais inženieris Pāvels Čeredničenko un stahanovietis Žanis Zuimačs personiski san,ēma Staḷina prēmiju. Tomēr jau 50. gadu sākumā, nomainoties uzṇēmuma direktoram, "Sarkandaugavas" produkcijas kvalitāte dramatiski kritās - kas atrada precīzu atspogul,ojumu citas trimdinieku avīzes raksta nosaukumā "No pasaules rekorda līdz brāḳim" (Latvija 1952, 37). Šis precedents vēlreiz apstiprina tēzi par to, cik daudz visdažādāko faktoru var ietekmēt kāda uzṇēmuma produkcijas kvalitāti un cik īsā laikā tā var kardināli mainīties.

Tāpat arī citu būvmateriālu kvalitāte mēdza svārstīties atkarībā gan no ražotāja, gan no produkcijas veida, gan izejvielu kvalitātes un virknes citu 


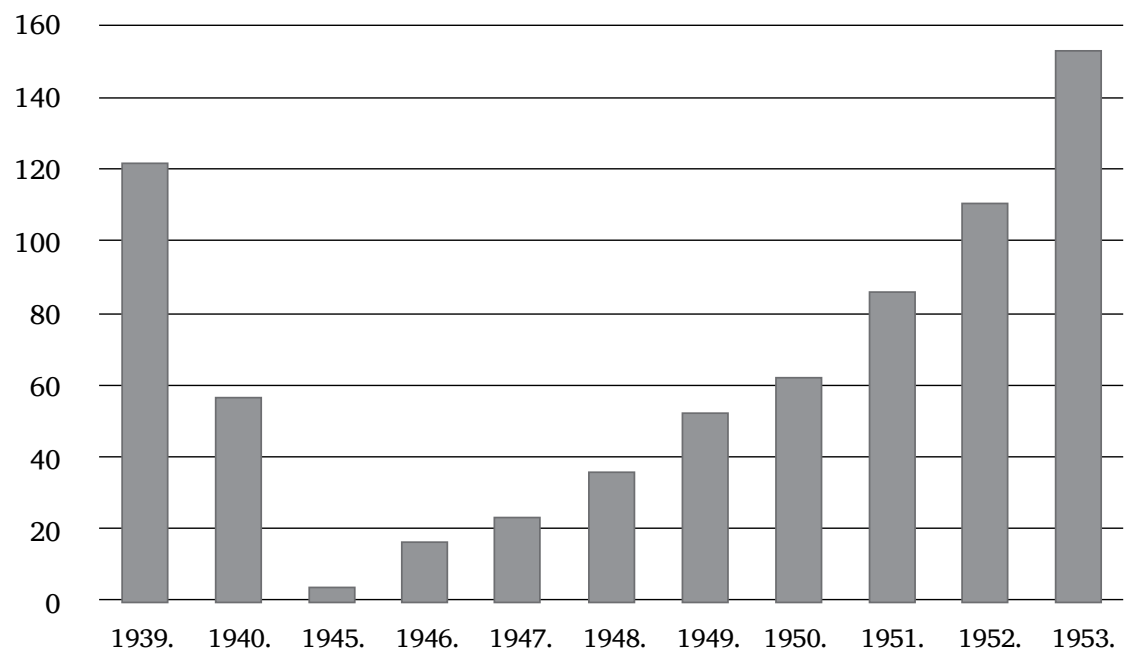

* - No 1945. lìdz 1953. gadam: bez Vietējās rūpniecỉbas TK / ministrijai pakḷauto sīko ceplu produkcijas

2. attēls. Svarīgākā būvmateriāla ražošanas apjomi LR un LPSR naturālā izteiksmē (1939.-1940., 1945.-1953. g.): apdedzinātie ķieǵeḷi (visu veidu), milj. gab. Autors: A. Petrovs

Figure 2. Production of the main building materials by volume in the Republic of Latvia and the Latvian SSR (1939-1940, 1945-1953): fired bricks (full range), mn pcs. Author: A. Petrovs

Avots: Latvijas PSR statistikas tabulas, 141; LNA-LVA, 1398-1-145, 48; LNA-LVA, 1398-1-146, 179; LNA-LVA, 1398-1-150, 109; LNA-LVA, 1398-1-153, 420-421; LNALVA, 1398-1-155, 165; LNA-LVA, 1398-1-157, 149; LNA-LVA, 1398-1-159, 129-130; LNA-LVA, 1398-1-161, 100; LNA-LVA, 1398-1-163, 69; LNA-LVA, 1398-1-186, 3.

faktoru. Piemēram, republikas lepnums - Rīgas gipša fabrika - turpināja izcilā sausā apmetuma jeb ǵipša plākšņu ražošanu, līdz pat 1949. gadam būdama vienīgā šì produkta ražotāja visā Padomju Savienībā (Ritenberga, Dombrovska 1968, 18). Visai augstas kvalitātes esot bijis arī cements, kura ražošanu pārṇēma vissavienības orgāni, un šīferis - viens no galvenajiem cementa izstrādājumiem. Par azbesta, otrās galvenās šîfera sastāvdaḷas, kaitīgumu cilvēka organismam tolaik vēl neviens nezināja.

Diezgan strauji attīstījās arī jaunu būvmateriālu ražošanas tehnoloǵiju apguve - ja 1944. gada beigās no vāciešiem atbrīvotajos uzn̄ēmumos ražoja vien septiņus dažādus produkcijas veidus, tad 1953. gadā - jau vairāk par 50. Pie interesantākajiem jauna veida būvmateriāliem var minēt siporeksu jeb gāzbetonu, tajā skaitā stiegroto, kā arī gípšsilikāta k,ieǵeḷus - par tiem ir atseviškss interesants stāsts: 1952. gadā Sauriešu gipša rūpnīcā esot izlaista šĩ pavisam jaunā būvmateriāla eksperimentālā partija. Presē tika ziņots, ka jaunā tipa ḳieǵẹ̦i atšḳiras no parastajiem silikātḳieǵeḷiem ar daudz lielāku 
salcietību un mehānisko izturību, kā arī tiem neesot vajadzīga ne žāvēšana, ne apdedzināšana (Socialisticheskij put' 1952, 136). Tomēr masveida ražošanā novatoriskie ķieǵeḷi nezināmu iemeslu dēḷ tā arī nenonāca, un nekādu papildu informāciju par šo gadījumu un minētajiem ḳieǵeḷiem pagaidām nav izdevies atrast.

Protams, ne tuvu ne visi augstākās kvalitātes materiāli tika ražoti vietējām vajadzībām - it īpaši, kad Latvijas PSR tautsaimniecībā beidzās "pēckara atjaunošanas posms" (ap 1950. gadu) un par galveno būvmateriālu rūpniecības mērḳi kḷuva jau sociālistiskās industrializācijas un kolektivizācijas materiālās bāzes nodrošināšana. Rūpnīcu korpusiem un kolhozu ēkām nebija vajadzīgi dārgi materiāli, arī to sortimentu varēja ierobežot līdz minimumam. Kopš 50. gadu sākuma Latvijas PSR uzñēmumi, tāpat kā citu padomju republiku ražotnes, ar sauso apmetumu, keramiskajām apdares flīzēm, ugunsizturīgajiem k̦ieǵel̦iem u. c. kvalitatīviem materiāliem apgādāja tā sauktās "lielās komunisma celtnes", piemēram, Maskavas Valsts universitātes ēku, Kuibiševas HES vai Galveno Turkmēnijas kanālu (Cīn,a 1951, 106; Cīn,a 1952, 13; Latvju Ziņas 1951, 5), bet ar pēc īpaša pasūtījuma ražotiem blokiem nodrošināja pat Maskavas Kremḷa atjaunošanas darbus (LNA-LVA, 1398-1-153, 421).

\section{SECINĀJUMI}

Apskatot iepriekš minētos piemērus, nevar nepamanīt divas pretējas tendences būvmateriālu ražošanas attīstībā pēckara Latvijas PSR: no vienas puses, neskatoties uz objektīvo svarīgumu, tā bija viena no rūpniecības nozarēm, kas atkopās vislēnāk, faktiski bremzējot celtniecību visā republikā īpaši akūti tas bija jūtams dzīvojamo ēku būvniecībā, kad dažās pilsētās, piemēram, Liepājā un Jelgavā, vietējās komunālās saimniecības iestādes ātrāk apguva būvmateriālu ražošanu no būvgružiem, nekā sagaidīja normālus materiālus no ražotājiem (Cīnna 1947, 193; Cīṇa 1949, 99; Komunists 1948, 57). No otras puses, dažas šīs jomas apakšnozares, kā stikla un ǵipša ražošana, jau pirmajos pēckara gados attīstījās pat daudz straujāk nekā Latvijas Republikas laikos.

Apkopojot nozares uzṇēmumu finansiālos rādītājus, tika konstatēts, ka no "plānoti nerentablās" nozares par ienesīgu Latvijas PSR būvmateriālu rūpniecība pārtapa ap 1950. gadu, bet 1953. gadā no 25 ministrijas uzñēmumiem ar zaudējumiem strādāja tikai septiṇi, tajā skaitā jaundibinātais Ogres karjers un Bolderājas silikātkieǵel̦u fabrika (tā rentabilitātes slieksni sasniedza 1959. gadā), turklāt lielāko peḷnu turpināja dot "Sarkandaugava" (4,5 milj. rubl̦u) un "Riǵipsis" (5,5 milj. rubḷu) (LNA-LVA, 1398-1-145, 9-10; LNA-LVA, 1398-1-146, 10; LNA-LVA, 1398-1-150, 120; LNA-LVA, 
1398-1-153, 17; LNA-LVA, 1398-1-155, 56; LNA-LVA, 1398-1-157, 8; LNA-LVA, 1398-1-159, 51; LNA-LVA, 1398-1-161, 53; LNA-LVA, 13981-163, 37).

Viens no pētījuma pamata problēmjautājumiem - vai būvmateriālu ražošanas nozares piemērs pietiekami labi reprezentē visas Latvijas PSR rūpniecības stāvokli pētāmajā laika posmā, faktiski tā arī palika atklāts. No vienas puses, šĩs nozares stāvoklis patiešām var kalpot par uzskatāmu piemēru tām grūtībām un problēmām, ar kurām saskārās padomju saimniecība pēckara krīzes apstākḷos - darbaspēka, ražošanas līdzekḷu un resursu trūkums, kapitālieguldījumu nesabalansētība, ne vienmēr prasmīga pārvalde utt. - turklāt dažas no iezīmēm, ņemot vērā pašsaprotamo vispārējo nepieciešamību pēc šīs nozares produkcijas, ir redzamas pat skaidrāk nekā citās jomās; no otras puses, Padomju Latvijas būvmateriālu rūpniecības atjaunošanas un attīstības gaitu nevar dēvēt par visai tipisku gadījumu kamēr dažu atsevišķu celtniecības un apdares materiālu ražošana noritēja priekšzīmīgi visas PSRS mērogā, citu - būvḳieǵeḷu - ražotṇu darbības rādītāji bija vieni no sliktākajiem salīdzinājumā ar visiem citiem republikas uzñēmumiem. Dažādu Padomju Savienības reǵionu, tautsaimniecības nozaru un pat vienas nozares apakšnozaru nevienmērīgie attīstības tempi neḷauj pilnā mērā attiecināt izpētīto piemēru uz Latvijas PSR vai PSRS rūpniecību kopumā, bet liek uzdot jautājumu par to, kas īsti šos tempus noteica plāns, kapitālieguldījumu apjoms, darba apstākḷi vai arī kādi citi faktori. Lai uz to atbildētu, turpmāk vēl padarāms milzīgs darbs avotu apzināšanā, izvērtēšanā un izpētē.

\section{SAĪSINĀJUMI}

AP - Augstākā Padome

ASV - Amerikas Savienotās Valstis

ĀRK - Ārkārtējā republikāniskā komisija

BKA - Baltijas kara apgabals

CK - Centrālā komiteja

GP - Galvenā pārvalde (glavks)

HES - hidroelektrostacija

IeM - Iekšlietu ministrija

LK(b)P/LKP - Latvijas Komunistiskā (boḷ̌seviku) partija / Latvijas Komunistiskā partija

LNA-LVA - Latvijas Nacionālā arhīva Latvijas Valsts arhīvs

LPSR - Latvijas Padomju Sociālistiskā Republika

LR - Latvijas Republika

MP - Ministru Padome

PSR - Padomju Sociālistiskā Republika

PSRS - Padomju Sociālistisko Republiku Savienība 
RGAE - Krievijas Valsts ekonomikas arhīvs (krievu val. - Rossijskij gosudarstvennyij arhiv ekonomiki)

SSR - Soviet Socialist Republic (anglu val.)

TK - Tautas komisariāts

TKP - Tautas Komisāru Padome

VPK - Valsts plāna komiteja

ZVA - Zonālais valsts arhīvs

\section{IZMANTOTIE AVOTI UN LITERATŪRA NEPUBLICÉTIE AVOTI}

IeM Karagūstekņu nometņu pārvaldes priekšnieka pulkveža Krastina vēstule LK(b)P CK Sevišḳā sektora vadītājam Kurbatovam par karagūstekṇu darbaspēka izmantošanu Krustpils kieǵeḷu rūpnīcā [krievu val.], 15.10.1946. Latvijas Nacionālā arhìva Latvijas Valsts arhìvs (Rīga, turpmāk: LNA-LVA), PA-101-9-82, 80. lp.

Kara jūrniecības celtniecības pārvaldes Nr. 5 galvenā inženiera Kosoja vēstule LK(b)P CK sekretāram celtniecības jautājumos I. Šilovam par trūkumiem būvmontāžas darbu plāna izpildē [krievu val.], 02.01.1948. LNA-LVA, PA-101-11-82, 1.-5. lp.

Latvijas PSR Būvmateriālu rūpniecības ministrijas Centrāāā grāmatvedība. Celtniecības un būvmateriālu rūpniecības TK 1945. gada pārskats [krievu val.], 1946. LNA-LVA, 1398-1-145.

Latvijas PSR Būvmateriālu rūpniecības ministrijas Centrālā grāmatvedība. Ministrijas 1946. gada koppārskats [krievu val.], 1947. LNA-LVA, 1398-1-146.

Latvijas PSR Būvmateriālu rūpniecības ministrijas Centrālā grāmatvedība. Ministrijas 1947. gada koppārskats [krievu val.], 1948. LNA-LVA, 1398-1-150.

Latvijas PSR Būvmateriālu rūpniecības ministrijas Centrālā grāmatvedība. Ministrijas 1948. gada koppārskats [krievu val.], 1949. LNA-LVA, 1398-1-153.

Latvijas PSR Būvmateriālu rūpniecības ministrijas Centrālā grāmatvedība. Ministrijas 1949. gada koppārskats [krievu val.], 1950. LNA-LVA, 1398-1-155.

Latvijas PSR Būvmateriālu rūpniecības ministrijas Centrālā grāmatvedība. Ministrijas 1950. gada koppārskats [krievu val.], 1951. LNA-LVA, 1398-1-157.

Latvijas PSR Būvmateriālu rūpniecības ministrijas Centrālā grāmatvedība. Ministrijas 1951. gada koppārskats [krievu val.], 1952. LNA-LVA, 1398-1-159.

Latvijas PSR Būvmateriālu rūpniecības ministrijas Centrālā grāmatvedība. Ministrijas 1952. gada koppārskats [krievu val.], 1953. LNA-LVA, 1398-1-161.

Latvijas PSR Būvmateriālu rūpniecības ministrijas Centrālā grāmatvedība. Ministrijas 1953. gada koppārskats [krievu val.], 1954. LNA-LVA, 1398-1-163.

Latvijas PSR Būvmateriālu rūpniecības ministrijas Plānošanas-ekonomikas dạa. Ministrijas atskaite par būvmateriālu izlaides plāna izpildi 1944.-1948. g. (LK(b)P Centrālkomitejai) [krievu val.], [1948]. LNA-LVA, 1398-1-190.

Latvijas PSR TKP Celtniecības un būvmateriālu rūpniecības GP Centrālā grāmatvedība. 1944. gada pārskats [krievu val.], 1945. LNA-LVA, 1398-1-144.

Latvijas PSR TKP Celtniecības un būvmateriālu rūpniecības GP pamatuzñēmumu raksturojums [krievu val.], 1944. LNA-LVA, PA-101-6-23, 122. lp.

Latvijas PSR TKP Celtniecības un būvmateriālu rūpniecības GP Plānošanas-ekonomikas daḷa. Latvijas PSR būvmateriālu ražošanas perspektīvais plāns 1944.-1947. g. ar paskaidrojumu [krievu val.], [1944]. LNA-LVA, 1398-1-186. 
Latvijas PSR TKP Celtniecības un būvmateriālu rūpniecības GP Plānošanas-ekonomikas daḷ. Pārskats par vācu fašistisko uzbrucēju TK uzṇēmumiem nodarīto zaudējumu [krievu val.], 1945. LNA-LVA, 1398-1-191.

LK(b)P CK sekretāra J. Kalnbērziņa vēstule VK(b)P CK sekretāram G. Maḷenkovam par ostās esošo materiālu nodošanu Latvijas PSR Būvmateriālu rūpniecības TK [krievu val.], 06.02.1946. LNA-LVA, PA-101-9-82, 5.-8. 1p.

\section{PUBLICĒTIE AVOTI}

B. a., 1945. Latvijas PSR dzīvokḷu un komunālās saimniecības darbinieku aktīva sanāksme. Cìna, 91, 4.

B. a., 1946. Latvijas stachanovieši uzstādījuši pasaules rekordu. Latviešu Zinas, 101, 2.

B. a., 1946. Sagatavosim dzivvokḷus ziemai. Komunists, 214, 1.

B. a., 1946. Ved atpakal vācu okupantu nolaupītās mašīnas. Cīna, 228, 4.

B. a., 1948. Jaunās technikas izcilie radītāji. Brīvā Venta, 86, 1-2.

B. a., 1951. Ko izved no Latvijas uz Turkmeniju. Latvju Zinas, 5, 1, 5.

B. a., 1952. No pasaules rekorda līdz brāḳim. Latvija, 37, 4.

B. a., 1952. Novye vidy stroimaterialov. Socialisticheskij put', 136, 4.

B. a., 1952. Šiferis - lielajām komunisma celtnēm. Cīna, 13, 1.

Civjans, G., 1947. LPSR Augstākās Padomes deputatu kandidati: Žanis Zuimačs. Padomju Jaunatne, 23, 2.

Dagda, J., 1947. Paplašina būvmaterialu aizvietotāju ražošanu. Cīna, 193, 2.

Deglavs, F., 1948. Latvijas rūpniecības stāvoklis un turpmākās attīstības perspektīvas. Karogs, 1, 92.

Efojs, J., 1946. Nodrošināt ķieǵeḷu ražošanas plāna izpildi. Cinna, 119, 3.

Kacena, V., 1946. Cīṇa ar stiklu. Karogs, 11/12, 1026-1035.

Kalns, R., 1948. Būvmateriali no ražošanas atkritumiem. Komunists, 57, 2.

Kunnoss, G., 1949. Būvdrupas - būvmaterialu izejviela. Cīna, 99.

Latvijas PSR statistikas tabulas (1940). Rīga: Latvijas PSR Tautsaimniecības statistikas pārvalde, 223 lpp.

Liepājs, V., 1951. Būvmateriali lielajām komunisma celtnēm. Cīna, 106, 4.

Likums, Z., 1946. Pasaules rekords. Pionieris, 33, 3.

Zujeva, R., b. g. Rūpniecības attīstība Jelgavas pilsētā 50.-60. gados. [Jelgava:] Jelgavas ZVA. Pieejams: https://www.arhivi.gov.lv/files/files/Digitalas\%20publikacijas/ Rupnieciba_Jelgava_1950_196_gados.pdf [Skatīts 01.09.2020.]

\section{LITERATŪRA}

Aizsilnieks, A., 1968. Latvijas saimniecības vēsture: 1914-1945. Stokholma: Daugava.

Bleiere D., Butulis I., Feldmanis I., Stranga A., Zunda A., 2005. Latvijas vēsture: 20. gadsimts. Rìga: Jumava.

Drīzulis, A. (red.), 1986. Latvijas PSR vēsture, 2. sēj. Rīga: Zinātne, 210-234.

Eiduks, J., Grosvalds, I., 1962. Cementa rūpniecības iesākums un attīstība Latvijas PSR teritorijā līdz 1941. gadam. No: Panovko, J. (atb. red.). Par tehnikas vēsturi Latvijas PSR, III sēj. Rīga: Latvijas PSR Zinātṇu akadēmijas izdevniecība, 149-194.

Krastiņš, E., 2018. Latvijas rūpniecība XIX-XXI gadsimtā: vēsturiski ekonomiska apcere. Rīga: Jumava.

Krūmiņš, G. (sast.), 2017. Latvijas tautsaimniecỉbas vēsture. Rīga: Jumava. 
Ritenberga, V., Dombrovska, V., 1968. Ķìmija Latvijā agrāk un tagad. Rīga: Zinātne. Šneidere, I., 1989. Socialisticheskaja industrializacija v Latvii: hod, itogi, problemy. Rīga: Zinātne.

\section{ATTÉLU, TABULU SARAKSTS}

1. attēls. Latvijas PSR būvmateriālu ražošanas uzṇēmumu nosacītā pārvaldes shēma (20. gs. 50. g. pirmā puse). Autors: A. Petrovs

Figure 1. Conventional scheme of the institutional structure of the Latvian SSR building-material enterprises (the first half of the 1950s). Author: A. Petrovs

1. tabula. Galveno Latvijas PSR rūpniecības nozaru kopprodukcijas izaugsme 1946.-1950. g., salīdzinot ar 1940. g. Autori: A. Drīzulis (ar A. Petrova papildinājumu)

Table 1. The growth of gross production of the Latvian SSR main industry sectors in 1946-1950 (compared with 1940). Author: A. Drīzulis (with addendum by A. Petrovs)

2. attēls. Svarīgāko būvmateriālu ražošanas apjomi LR un LPSR naturālā izteiksmē (1939.-1940., 1945.-1953. g.): apdedzinātie ķieǵeḷi (visu veidu), milj. gab. Autors: A. Petrovs

Figure 2. Production of the main building materials by volume in the Republic of Latvia and the Latvian SSR (1939-1940, 1945-1953): fired bricks (full range), mn pcs. Author: A. Petrovs

\section{ATSAUCES UN PIEZİMES}

${ }^{1}$ Lēmums par valdošās partijas nosaukuma maiņu no Vissavienïbas Komunistiskā (bolšseviku) partija $(V K(b) P)$ uz Padomju Savienibas Komunistiskā partija (PSKP) tika pieñemts partijas XIX kongresā (1952. g. oktobrī) un, pašsaprotami, bija saistošs arī republikas partijām.

${ }^{2}$ PSRS Tautas komisariāti tika pārdēvēti par ministrijām 1946. gada administratīvajā reformā.

${ }^{3}$ Būvmateriālu rūpniecības produkcijas apjoms 1947. gadā deva vien 6 \% no visas Latvijas PSR rūpniecības kopprodukcijas (Karogs 1948, 1), bet 1950. gadā no visa republikas rūpniecībā nodarbināto skaita būvmateriālu ražošanas uzṇēmumu darbinieki veidoja tikai 3,8 \% (Krastiņš 2018, 186).

${ }^{4}$ Piemēram, 1946. g. 21. maija "Cīņas" numurā, spriežot par Kalnciema k̦ieǵeḷu rūpnīcu grupas neapmierinošajiem darba rādītājiem, tika uzsvērts, ka "galvenais iemesls [tam] - trūkst elektromotoru un ekskavātoru, kuṛu Būvmateriālu rūpniecības ministrija iedevusi pagaidlietošanai Rīgas jūṛas būvju trestam, bet pēdējais nesteidzas atdot atpakaḷ" un "arī iztrūkstošie motori ķieǵeḷūūpniecības trestam ar Būvmateriālu rūpniecības ministrijas rīkojumu atņemti un aizsūtīti uz Sauriešu gipša karjeru un siporeksa rūpnīcu".

Cita zīmīgā liecība tam ir J. Kalnbērziṇa 1946. gada 6. februāra slepenā vēstule G. Maḷenkovam, kurā viņš prasa pieškirt daḷu no Vācijas atvestām rūpnieciskajām iekārtām Latvijas PSR būvmateriālu rūpniecības vajadzībām: "[...] Okupācijas un vācu karaspēka atkāpšanās no Latvijas teritorijas gaitā būvmateriālu rūpniecības uzn̄ēmumi tika gandrīz pilnīgi sagrauti, bet lielākā daḷa to aprīkojuma izvesta uz Vāciju. Ar lielām grūtībām, pateicoties vietējiem resursiem, Latvijas PSR izdevās 
daḷēji atjaunot būvmateriālu rūpniecību, kura nestrādā ar pilnu jaudu. [..] Ar pašu spēkiem Latvijas PSR nav spējīga atjaunot sagrauto rūpniecību atbilstošā aprīkojuma dēḷ. [..] Turklāt Liepājas /Lībavas/ un Ventspils /Vindavas/ ostās atrodas un turpina ienākt PSRS Būvmateriālu rūpniecības TK adresētas iekārtas un materiāli no Vācijas, kuras iegūstot [Latvijas Būvmateriālu rūpniecības TK] varētu nodot ekspluatācijā tādas lielās būvmateriālu rūpnīcas kā Brocēnu cementa un šîfera rūpnīca, [...] Kalnciema k̦ieğeḷu kombināts [..] u. c. [..] Lūdzu Jūsu rīkojumu PSRS Būvmateriālu rūpniecības TK par Liepājas un Ventspils ostās esošo aprīkojumu nodošanu Latvijas PSR Būvmateriālu rūpniecības TK [..]" (LNA-LVA, PA-101-9-82, 5)

${ }^{5} 100$ \% ražošanas jaudas zaudējums nozīmē, ka bez kapitālremonta uzn̄ēmums nevar atjaunot ražošanu. Par iemeslu tam bija ražošanas iekārtu un/vai dzinēju dal̦ēja vai pilnīga izvešana, sabojāšana vai iznīcināšana, kā arī ražošanas korpusiem nodarītie būtiskie bojājumi, kas nebija savienojami ar ražošanas turpināšanu. No Cēsu kieǵeḷu rūpnīcas, kuras ražošanas jaudas zaudējums tika vērtēts $80 \%$ apmērā, tika izvesta daḷa no iekārtām un dzinējiem, bet tās èkas nebija cietušas. No $50 \%$ apmērā cietušajiem kaḷ,ku cepliem bija izvests inventārs un instrumenti, bet Apes cepḷa $20 \%$ zaudējumi ir saistīti vienīgi ar dạ̣ējiem cepḷa ēkas bojājumiem. 


\title{
INDUSTRIAL RECOVERY AND DEVELOPMENT OF SOVIET LATVIA IN THE 1940s-1950s: THE EXAMPLE OF BUILDING MATERIALS PRODUCTION SECTOR
}

\author{
ALEKSANDRS PETROVS \\ Mg. hist., senior archivist at the Department of Document Preservation, \\ Latvian National Archives, Latvian State Archive \\ E-mail: aleksandrs.petrovs@arhivi.gov.lv
}

\begin{abstract}
The purpose of this paper is to introduce the main trends and problems of industrial development in the Latvian SSR after World War II, which is illustrated by the example of the building materials industry as one of the bottlenecks in state industry.

The present paper was preceded by research on the structure of the national economy of the Latvian SSR and the process of its recovery during the period from the end of World War II to 1953, conducting in-depth research of one of its sectors - the industry of building materials, paying special attention to the manufacturing process and products, as well as to the key performance indicators.

The result of the study shows that, although strategic importance was given to the production of building materials, as it had to be developed rapidly, its condition was discrepant from the claimed priority during the study period.
\end{abstract}

Keywords: Latvian SSR, national economy, economics, industry, production, building materials.

\section{SUMMARY}

The events of 1940-1941 and World War II radically changed the form and matter of the Latvian economy. After the war, it virtually had to be rebuilt from the ground up by combining the remnants of the pre-war economy with completely new principles of economic activity based on Marxist political economy theory.

Nevertheless, the study of this process is not entirely extraneous to the current historiography. In looking at the renewal and development features of industry in the Latvian SSR, researchers have been focusing mainly on either the most rapidly growing sectors of the Soviet system, such as metalworking, machine and apparatus construction, or the status of the previously leading industries of the former Republic of Latvia (wood and 
food industries). Behind them, an industry that is extremely important in the context of the post-war recovery - the production of building materials - has remained almost unnoticed, although its products served as the material base for all industrial, rural, communal and military sectors of the economy.

The documents stored in the National Archives of Latvia, as well as the periodicals of that time show that, despite the importance of the building material sector, its renewal and development has been atypically difficult and slow, even when compared to light industry and agriculture. The sources show both the obstacles that hindered the development of building materials production and the considerable success of the sector in the first post-war years - from the invention of innovative building materials to world records in glass production. 


\title{
LATVIJAS KOMUNISTISKĀS PARTIJAS SATELİTORGANIZĀCIJAS 20. GADSIMTA 20. GADOS: RĪGAS ARODBIEDRĪBU CENTRĀLBIROJA PIEMËRS
}

\author{
GUNA PLAKANE
}

Mg. hist., Latvijas Universitātes Vēstures un filozofijas fakultātes doktorante, Latvijas Nacionālā vēstures muzeja pētniece

E-pasts: guna.plakane@Invm.Iv

\begin{abstract}
ANOTĀCIJA
Nozīmīgākā galēji kreisā PSRS atbalstītā organizācija starpkaru Latvijā bija Latvijas Komunistiskā partija (LKP). Tā kā komunistiskām organizācijām Latvijā legāli darboties bija aizliegts, LKP darbojās pagrīdē. Lai vairotu savu ietekmi sabiedrībā, LKP iefiltrējās legālās biedrībās, kā arī dibināja formāli patstāvīgas organizācijas, kas bija politiski atkarīgas no LKP. Rakstā sniegts ieskats LKP satelītorganizāciju darbībā 20. gadsimta 20. gados, izmantojot Rīgas Arodbiedrību centrālbiroja (RABCB) piemēru. RABCB visos tā darbības virzienos vērsās pret pastāvošo valsts iekārtu, iestājās par radikāliem risinājumiem sociālajā un politiskajā jomā un ciešiem sakariem ar PSRS. LKP ar RABCB starpniecību nodrošināja pieeju plašākām sabiedrības aprindām, kas deva iespēju dažādos veidos izvērst nelegālās organizācijas propagandu.
\end{abstract}

Atslēgas vārdi: Latvijas Komunistiskā partija, Rīgas Arodbiedrību centrālbirojs, sabiedriskās organizācijas, satelītorganizācijas, komunisti.

\section{IEVADS}

Nozīmīgākā galēji kreisā organizācija starpkaru Latvijā bija Latvijas Komunistiskā partija (turpmāk LKP). Tās darbībā noteicošā loma bija sakariem ar Padomju Krieviju (no 1922. gada ar Padomju Sociālistisko Republiku Savienību (turpmāk PSRS)), kas Latvijā, tāpat kā citās reǵiona valstīs, mērḳtiecīgi organizēja un finansēja komunistisko kustību un grāva valstu 
iekšējo drošību. Tā kā komunistiskām partijām un organizācijām Latvijā legāli darboties bija aizliegts, LKP darbojās pagrīdē. Lai vairotu savu ietekmi sabiedrībā, LKP darbību īstenoja, mijiedarbojoties nelegālajam un legālajam darbam. Šie darbības veidi tika realizēti caur nelegālo organizāciju tīklu, iefiltrējoties dažādās legālajās biedrībās, kā arī iniciējot jaunu - formāli patstāvīgu organizāciju izveidi, kas faktiski bija pakḷautas LKP interesēm.

Viena no nozīmīgākajām un lielākajām LKP satelītorganizācijām, kas no 1924. gada līdz tās slēgšanai 1928. gadā darbojās kā LKP legālā darba organizācijas centrs, bija Rīgas Arodbiedrību centrālbirojs (turpmāk - RABCB). Centrālbirojs apvienoja daḷu Rīgas arodbiedrību, aizstāvēja strādnieku sociālpolitiskās intereses un organizēja kultūras un izglīīibas pasākumus. Tajā pašā laikā dạ̣a RABCB biedru bija komunistisku ideju piekritēji, un, tā kā organizācijas vadība bija LKP rokās, tā faktiski noteica centrālbiroja darbības līniju.

Raksta mērkis ir sniegt ieskatu LKP satelītorganizāciju darbībā 20. gadsimta 20. gados, izmantojot RABCB piemēru. Pētījumā jēdziens "satelītorganizācija" tiek attiecināts uz tādām organizācijām, kuras formāli ir patstāvīgas, bet ir politiski atkarīgas no LKP. Pētījuma hronologiskās robežas saistitas ar RABCB darbības laiku no 1919. gada 15. augusta, kad tas tika dibināts, līdz 1928. gada 28. novembrim, kad RABCB un tās paspārnē esošās arodbiedrības tika slēgtas. Izvēlētā tēma ir būtiska un zinātniski aktuāla, jo RABCB piemēra izpēte l̦auj pilnveidot priekšstatus par LKP darbības raksturu, apmēru, satelītorganizāciju tīklu un tiek veicināta izpratne par politisko vidi starpkaru Latvijā.

Ziṇas par LKP satelītorganizācijas RABCB darbību sniedz nepublicētie vēstures avoti, kas glabājas Latvijas Nacionālā arhīva Latvijas Valsts vēstures arhīvā (turpmāk - LNA-LVVA) un Latvijas Kara muzeja (turpmāk LKM) dokumentu krājumā. RABCB iekšējās lietvedības dokumenti (normatīvie dokumenti, prezidija sēžu protokoli) kopumā sniedz detalizētu informāciju par organizācijas oficiālajiem mērkịiem, struktūru un iekšējo darbību. Tajā pašă laikā jāuzsver, ka RABCB dokumentācija tika veidota piesardzīgi, lai tiesībsargājošajām institūcijām neatklātos tā pretvalstiskā darbība un saistība ar LKP. Tādēḷ, piemēram, statūtos aprakstītā organizācijas darbība aprobežojas ar sociālo jomu, strādnieku kultūras un izglītības līmen,a celšanu. Lìdz ar to šie dokumenti savrupi neatspogulo visus RABCB darbības aspektus, tādēl būtiska nozīme ir tiem dokumentiem, kas bija paredzēti tikai iekšējai lietošanai - prezidija sēžu protokoliem. Tikpat būtiski tēmas izpētē ir tiesu un izmeklēšanas materiāli RABCB lietā (LKM, 23044/21707(2)-VII). Lai gan pilns tiesu izmeklēšanas materiālu komplekts nav saglabājies, šie avoti l̦auj no cita skatu punkta izvērtēt organizācijas darbību. Plašs organizācijas vērtējums tiek sniegts iekšlietu ministra Eduarda Laimiṇa (1882-1982) ierosinājumā par RABCB slēgšanu 
(LKM, 23044/21707(2)-VII), ilustrējot centrālbiroja darbības pretlikumīgo raksturu - sadarbību ar LKP, pretvalstisko ağitāciju, musināšanu pret valsts iekārtu, jau apkīilātu izdevumu tālāku izplatî̌sanu u. tml. Šajos dokumentos sniegtā informācija liecina, ka Politiskā pārvalde bija labi informēta par RABCB pretvalstisko darbību un sakariem ar LKP. Pētījumā plaši izmantoti arī publicētie avoti - LKP konferenču materiāli, RABCB biedru atmiņas, periodika, tiesību akti -, kas būtiski papildina nepublicēto avotu sniegto informāciju. Tāpat pētijjumā izmantoti līdz šim tapušie darbi par LKP darbību starpkaru Latvijā. Pārsvarā tie ir pētijumi padomju historiogrāfijā, kuru saturs ir tendenciozs, piemēram, tiek pārspīlēts RABCB politiskās aktivitātes masveidīgums, ietilpstošo biedru skaits un citi aspekti. Tomēr pētijuma kontekstā kā nozīmīgs ir jāizceḷ vēsturnieces Ilgas Kapenieces darbs, kurā, par spīti dažbrīd sastopamajiem tendenciozajiem apgalvojumiem, autore izmantojusi plašu un daudzveidīgu avotu klāstu un sniegusi ieskatu LKP nelegālā un legālā darba savienošanā parlamentārisma posmā. Atsevišķi darbi, kas būtu veltīiti LKP satelītorganizāciju darbībai, kopš Latvijas neatkarības atjaunošanas vēl nav tapuši.

\section{LATVIJAS KOMUNISTISKĀS PARTIJAS DARBĪBA LEGĀLAJĀS ORGANIZĀCIJĀS}

Lai gan 20. gadsimta 20. gadu sākumā LKP darbībā uzsvars bija uz tās nelegālā darbības tīkla nostiprināšanu, LKP 18. konferencē 1920. gada jūnijā tika pievērsta uzmanība arī tās darbības mērḳiem legālajās organizācijās. Konferencē tika uzsvērta nepieciešamība veikt plašu aǵitāciju strādnieku vidū, izmantot ikkatru iespēju veikt legālu darbu, tādā veidā legālās strādnieku organizācijas pārvērst par dalı no LKP satelïtorganizāciju tīkla (Latvijas Komunistiskās partijas kongresu, konferenču un CK plēnumu rezolūcijas un lēmumi 1958, 244). Lai realizētu šo mērḳi, par katra LKP biedra pienākumu tika noteikts iefiltrēties strādnieku legālajās organizācijās, izvērst tajās komunistisku aǵitāciju, tādā veidā tās padarot par "aktīvu ieroci komunistiskās šḳiru cīṇas darbā" (Latvijas Komunistiskās partijas kongresu, konferenču un CK plēnumu rezolūcijas un lēmumi 1958, 244). Ar šãdiem mērķiem komunisti darbojās gan studentu, kultūras un sporta biedrībās, gan strādnieku klubos un kooperatīvos.

LKP pieejai darbam legālajās organizācijās 20. gadsimta 20. gados bija raksturīgi, ka pēc LKP iniciatīvas tika dibinātas biedrības, kuru statūtos tieša saistība ar politisko darbību neparādās. Ja reǵistrēšanai iesniegtie organizācijas statūti atbilda biedrību darbību regulējošajam likumam (Likums par biedrībām, savienībām un politiskām organizācijām 1923, 196-198) un nebija pretrunā ar citiem valstī spēkā esošajiem likumiem, konkrētajai 
apgabaltiesai nebija iemesla to nereǵistrēt biedrību reǵistrā. Piemēram, 20. gadu vidū pēc LKP iniciatīvas tika nodibināta strādnieku fiziskās kultūras biedrība "Eneróija", kas organizēja fiziskas aktivitātes, debates u. c. pasākumus, paralēli veicot komunistisku ağitāciju (Mednis 1998, 34). Lai gan tiesībsargājošās iestādes bija konstatējušas biedrības "Enerğija" pretvalstiskās darbības, kas bija pretrunā ne tikai ar likumiem, bet arī neatbilda organizācijas oficiālajiem mērķiem, jebkuras organizācijas slēgšanas process bija laikietilpīgs, prasīja ievākt pietiekami daudz ziṇu par tās darbību, kā rezultātā ar tiesas lēmumu bija iespējams tās slēgt. Pēc biedrības "Enerǵija" slēgšanas 1926. gadā tika izveidota Latvijas Strādnieku jaunatnes biedrība, pēc tam biedrība "Fizkultūra", kas, par spīti tam, ka reāli organizācijas darbība nemainījās un tā turpināja nodarboties ar komunistisku aǵitāciju, l̦āva tai ar citu nosaukumu turpināt darbību legāli.

Lai centralizēti organizētu legālo darbu, 20. gadsimta 20. gadu sākumā tika izveidots legālā darba organizācijas centrs, kas bija tieši pakḷauts LKP Centrālajai komitejai (turpmāk - LKP CK); tas sastāvēja no LKP CK locekliem, LKP Rīgas komitejas un RABCB prezidiju pārstāvjiem (Ozoliņš 1983, 177). Legālā darba organizācijas centra galvenais uzdevums bija visā Latvijas teritorijā organizēt un koordinēt arodbiedrību apvienības un tajās izveidot komunistu frakciju tīklu (Kapeniece 1981, 149). Par LKP taktiku legālajās organizācijās bija labi informēta arī Politiskā pārvalde - viens no tās operatīvās darbības virzieniem bija sekot līdzi tam, vai legālo biedrību darbība nav bīstama valsts iekšējai drošībai. Pēc Politiskās pārvaldes rīcībā nonākušajiem materiāliem par LKP 22. konferenci 1923. gada jūnijā, tā bija konstatējusi, ka LKP mērḳis ir pie visām arodbiedrībām nodibināt komunistu frakcijas, kas darbojās ciešā saistībā ar vietējo LKP organizācijas komiteju (LKM, 23044/21707(2)-VII, 1). Komunistu frakcijas apvienoja konkrētajā biedrībā esošos LKP biedrus, savukārt, lai koordinētu darbu starp vairākām komunistu frakcijām, tika izveidots Legālo biedrību komunistiskais birojs jeb Starpfrakciju birojs. Tas bija pakḷauts LKP Rīgas komitejai un sastāvēja no frakciju pārstāvjiem. LKP lēmumi un darbības līnija legālajās organizācijās tika realizēta caur Starpfrakciju biroju un RABCB prezidiju (Ozoliņš 1983, 178). 20. gados LKP komunistu frakcijas izveidoja arī vairākās Rīgas slimokasēs, strādnieku kooperatīvos, kultūras biedrībās un citās legālajās organizācijās. Pēc LKP biedru arestiem 1924. gadā legālās darbības centra funkcijas pārn,ēma RABCB, ko noteica organizācijas centrālā loma kreisajās arodbiedrībās, pēc LKP norādījumiem ìstenotā retorika dažādos sociālpolitiskos jautājumos, izteiktas simpātijas pret PSRS u. tml. 


\section{RĪGAS ARODBIEDRĪBU CENTRĀLBIROJA DARBĪBAS RAKSTUROJUMS}

RABCB savu darbību uzsāka 1919. gada 15. augustā. 1920. gada 30. martā Rīgas apgabaltiesas reǵistrācijas nodaḷa to fiksēja savienību registrā; tā oficiālais mērkis bija veicināt arodkustības attīstību un aizstāvēt strādnieku sociālpolitiskās intereses sabiedrībā (LKM, 23044/21707(2)VII, 1). Centrālbirojā ietilpstošo arodbiedrību un to biedru skaits bija mainīgs - vislielākais arodbiedrību skaits bija RABCB darbības sākumā - tas svārstījās no 20 (Arodnieks 1920, 1, 6) līdz 26 (Arodnieks 1922, 8, 67) arodbiedrībām 1919. gada nogalē līdz 12 apvienotajām arodbiedrībām 1925. gadā (Strādnieku laika grāmata 1925. gadam 1925, 78); 1928. gadā tika slēgtas 13 RABCB ietilpstošās arodbiedrības. Centrālbirojā ietilpstošo arodbiedrību skaita samazināšanos bija konstatējuši sociāldemokrātu arodbiedrību biedri, par ko kāds Latvijas Arodbiedrību centrālbiroja (turpmāk LABCB) biedrs, kurš piedalījās RABCB gada sēdē 1922. gadā, rakstijja: "RABCB ieejošo organizāciju skaits ir noslīdējis no 26 uz 13-15, tā tad no organizētām apvienībām tagadējais virziens ir atstūmis gandrīz pusi, citas ir aiziešanas stadijā. [..] Vairākas arodbiedrības kaunās uzdot savu faktisko biedru skaitu un to apzinigi slēpj. Priekšstāvjus uz C. B. [centrālbiroju] sūta no pagājušajā gadā reǵistrētā biedru sastāva, ko pēc mirušām dvēselēm, pārtrumpojot Gogoḷa varoni, "mirušo dvēseḷu" falsifikācijā" (Arodnieks 1922, 8, 67). Par RABCB ietilpstošo arodbiedrību aiziešanas motīviem sociāldemokrāti min tā politisko orientāciju, kas, kā tālāk norāda LABCB biedrs, novedīs pie RABCB darbības izsīkuma. RABCB iekšējās darbības dokumentos informācija par centrālbirojā ietilpstošo arodbiedrību skaitu parādās reti. 1925. gada 12. janvāra paplašinātajā prezidija sēdē tika konstatēts, ka arodbiedrībās biedru pieaugums novērojams tad, kad ir izcēlušies streiki vai tiek organizētas sapulces, savukārt drīz pēc tam biedru skaits samazinās (LNA-LVVA, 3980-1-1, 38). Arī biedru skaits kreisi noskan,otajās arodbiedrībās 20. gadsimta 20. gados krasi samazinājās 1922. gadā tie bija 14970 biedri, bet 1928. gadā vien 4736 (Bērziña, Vāveris 2020, 186).

RABCB prezidijs tika komplektēts no LKP locekḷiem, kuri organizēja centrālbiroja darbu un rīkoja dažādus pasākumus par politiskiem tematiem, kas saskaņoti ar LKP taktikas prasībām legālajās organizācijās un Komunistiskās Internacionāles aktuālās politikas jautājumiem (LKM, 23044/21707(2)VII, 2). Par RABCB tiešo saistību ar LKP liecināja arī 1922. gadā notikušie arodbiedrību biedru aresti, kuru laikā par komunistisku darbību tika arestēti, piemēram, RABCB prezidija loceklis Augusts Liberts (1876-1938) u. c. prezidija locekḷi, kas LKP 21. konferencē tiek ziņots kā iemesls divu LKP rajonu dezorganizācijai (LKM, 23044/21707(2)-VII, 1). 
Būtisks aspekts RABCB darbībā bija strādnieku sociālo jautājumu risināšana. Tā pamatā bija LKP CK 1922. gada sākumā izstrādātā vienotā programma, kas tika veidota pēc Komunistiskās Internacionāles 3. kongresā 1921. gadā un Komunistiskās Internacionāles Izpildu komitejas 1921. gada decembrī pieņemtajiem lēmumiem (Arnte 1964, 131). LKP sociālās politikas platformas galvenās prasības pieñēma arī RABCB 1922. gada 24. februāra plenārsēdē (Darbs un Maize 1922, 5, 151-153). Rezolūcijā tika definētas prasības bezdarba jautājumos, laukstrādnieku jautājumos, kā arī noteiktas tīri politiskas prasības, kas bija saistītas ar arodbiedrību biedru un citu cilvēku, kuri piekopuši pretvalstiskas darbības un par tām tikuši sodīti, atbrīvošanu (Darbs un Maize 1922, 5, 151-153).

Tāpat RABCB organizēja streikus - to rīkošanas taktika balstījās uz Sarkanās Arodbiedrību Internacionāles un LKP norādījumiem (Brikšķis 1928, 161). Streikiem, kuru atbalstīšanā iesaistījās RABCB, raksturīgi, ka primāri tika nostādīta LABCB un sociāldemokrātu diskreditēšana, par ko sniegtas ziņas arī presē: "Ar apbrīnojamu bezkaunību mūsu "kreisie arodnieki" izlietoja strādnieku saimnieciskās cīn,as, lai sarīdītu strādniekus pret sociāldemokrātiju. Šinī kampaṇā pret sociāldemokrātiju viņiem pat viszemiskākie līdzekḷi izrādījās par noderīgiem.” (Brikšḳis 1928, 161) Tāpat streiki tika izmantoti kā vērtīgs instruments, kā caur kreisajām arodbiedrībām LKP izvērsa savu darbību plašākās strādnieku aprindās.

LKP politiskā līnija tika aktualizēta arī RABCB kultūras pasākumos. Piemēram, centrālbiroja kluba dramatiskās sekcijas strādnieku teātra galvenais darbības mērḳis bija aktualizēt sociālpolitiskus jautājumus, tajā pašā laikā veicot arī aktīvu propagandas un ağitācijas darbu (Kundziņš 1972, 221). Pēc RABCB biedra un rakstnieka Leona Paegles (1890-1926) aicinājuma par centrālbiroja strādnieku teātra režisori 1925. gadā kḷuva Anna Lācis (1891-1979). Režisore atmin̄ās par L. Paegli min kādu sarunu, kurā rakstnieks raksturo RABCB kultūras darbības reālo raksturu: "Tagad jārada īsts aǵitācijas teātris, kas stingri stāvētu partijas pozīcijās. Mūsu repertuārs vēl pārāk kūtri un neskaidri cīnās par strādnieku škiriras interesēm. Mums jāmāca strādnieki pareizi domāt, jārāda tiem pareizais ceḷš [..], revolucionārais gars un škiras apziņa. Enerğiski jācīnās pret politisko oportūnismu, kuru masām grib iepotēt menševiki, un jāaudzina jaunatne. Visiem šiem uzdevumiem pašlaik ir diezgan labi pamati - ir aktīvi jauno strādnieku kadri, kas mīl mākslu un kreisās arodbiedrības, kuras izvērš spraigu politisku darbību.” (Lācis 1961, 139) Līdz ar to RABCB kultūras pasākumi pamatā darbojās kā politiskās aǵitācijas platforma, kura ne tikai dramatiskās sekcijas dalībniekiem, bet, protams, tās mērḳa auditorijai (strādniekiem un pēc iespējas plašākām masām) pasniedza tā laika sociālpolitiskos notikumus LKP interpretācijā.

Pagrīdes komunisti izmantoja RABCB arī kandidēšanai Rīgas pilsētas pašvaldības vēlēšanās. Piemēram, vēlēšanās 1922. gada 12. martā RABCB 
piedalījās ar sarakstu Nr. 10. "Rīgas arodbiedrību centrālbiroja, strādnieku kooperācijas darbinieku un 1. dzīvokḷu īrnieku savienība", par ko nobalsoja 16786 balsstiesīgo, līdz ar to no 90 mandātiem tika iegūti 13 (Rìgas pilsētas gada grāmata 1931. gadam. 1931, 21). Vēlēšanu platformas izstrādāšanā piedalījās Vilis Dermanis (1875-1938), L. Paegle un Linards Laicens (18831938) (Krūmiņš, Pupurs 1970, 60). Tajā izteikti kritizēta pastāvošā valsts iekārta, tiek piedāvāti radikāli risinājumi saimnieciskajā jomā, kā arī tiek pieprasīts nekavējoties atjaunot saimnieciskos sakarus ar Padomju Krieviju (Darbs un Maize 1922, 4, 119-123). Cenšoties realizēt vēlēšanu platformā ietverto programmu, Rīgas pilsētas domes kreiso arodnieku frakcijas pārstāvis V. Dermanis 1922. gada 6. aprịla domes sēdē nolasīja frakcijas sagatavoto deklarāciju. Tajā tika pazin,ots, ka Rīgas pilsētas dome joprojām nav spērusi nepieciešamos radikālos soḷus, lai likvidētu saimnieciskās problēmas un uzlabotu strādnieku stāvokli. Tāpat, izejot no RABCB - LKP pozīcijām, deklarācijā norādīts, ka Latvijā nav vēl realizētas tādas demokrātijas pamatvērtības kā preses un biedrošanās brīvības strādniekiem. Šeit gan jāpiebilst, ka, ievērojot likumos noteikto procedūru, bija aţ̦auts gan izdot preses izdevumus, gan biedroties - šeit uzmanība pastarpināti tika vērsta tieši uz RABCB un visu kreiso arodbiedrību problemātiku, par ko deklarācijā teikts: "Pastāvošie izṇēmuma stāvokḷi, administratīvie spaidi, pat patvarības pret strādnieku kustības kreisajiem virzieniem, sevišķi pret komunistisko, dezorganizē un apgrūtina strādnieku organizāciju darbību" (Darbs un Maize 1922, 6, 184-185).

RABCB nodarbojās arī ar nelegālas komunistiskas literatūras turēšanu un izplatīšanu, kā arī deva iespēju LKP aiz centrālbiroja aizsega izdot legālus izdevumus. Tie bija izteikti opozicionāri pret demokrātiskās valsts iekārtu, legālajām politiskajām partijām un bija orientēti uz to, lai veidotu sabiedrisko domu par labu PSRS un tās ideologijai. Visvairāk izdevumu RABCB izdeva laika posmā no 1924. gada līdz RABCB slēgšanai 1928. gadā, kas aizsākās ar RABCB nedēḷas žurnālu "Vienība”. Žurnāla iznākšana vairākkārt tika apturēta par pretvalstisku aǵitāciju, tādēḷ šajā laikā iznāca vairāki pēc žanra, izcelsmes un satura vienādi žurnāli, kur visos žurnālu nosaukumos parādījās vārds "vienība", lai lasītāji varētu to atpazīt. Žurnāla izdošanai līdzekḷi pārsvarā tika savākti no RABCB ietilpstošajām arodbiedrībām, kā arī daḷu izdevumu sedza LKP (K,ipers 1970, 77). Par žurnāla "Vienība" un tā turpinājumizdevumu legālu iznākšanu rūpējās RABCB, kas koncesijā norādīja atbildīgo redaktoru. Parasti šo personu izvirzīja no arodbiedrību vides un kas gadījumā, ja izdevums tiktu apturēts un konfiscēts, izciestu piemēroto sodu. Savukārt LKP vadībā darbojās žurnāla nelegālā redakcijas kolēǵija, kurā, piemēram, no 1925. gada līdz 1927. gadam darbojās LKP CK loceklis Mārtiņš Ozols (1879-1938) (K,ipers 1970, 78). Nelegālā redakcijas kolēǵija rediǵēja RABCB žurnālus, vadoties pēc LKP CK noteiktā politiskā kursa (K,ipers 1970, 79). 
Balstoties uz Politiskās pārvaldes ievāktajiem materiāliem, kas apliecināja RABCB pretvalstisko darbību, 1928. gada 19. jūlijā iekšlietu ministrs E. Laimiņš ierosināja tā slēgšanu. RABCB bija pārkāpis statūtos noteiktos mērḳus, realitātē darbojoties kā "maskēts nelegālās komunistiskās partijas legālās darbības orgāns strādnieku masu apvienošanai un to revolucionizēšanai tālāko komunistiskās partijas mērḳu, t. i., Latvijas valsts apvērsuma, izvešanas nolūkam" (LKM, 23044/21707(2)-VII, 1). Šis apgalvojums labi raksturo RABCB reālo darbību un Politiskās pārvaldes informētību par to, jo RABCB līdz 1928. gadam faktiski darbojās kā LKP legālā darba organizācijas centrs. Pēc ierosinājuma nodošanas Rīgas apgabaltiesā E. Laimiņš izteicās, ka lēmumu šo lietu ierosināt 1928. gada jūlijā noteica RABCB un tajā ietilpstošo arodbiedrību pretvalstiskā darbība un komunistiskā ağitācija, kas pēdējos mēnešos "uz ārieni izpaudās sevišḳi krasi un izaicinoši" (Latvijas Kareivis 1928, 166, 3). Iekšlietu ministrs uzsvēra, ka RABCB darbība, kas bija tieši vērsta pret pastāvošo valsts iekārtu un visas ar to saistītās darbību izpausmes norādīja uz to, ka tas pastarpināti îsteno LKP mērķus.

1928. gada 28. novembrī RABCB slēgšanas lieta atkal nonāca dienas kārtībā - tā no jauna nonāca Rīgas apgabaltiesas administratīvās nodaḷas tiesā (Iekšlietu Ministrijas Vēstnesis 1928, 257, 2). Iestājoties par RABCB un tajā ietilpstošo arodbiedrību slēgšanu, Politiskās pārvaldes priekšnieks Voldemārs Ozoliṇš (1891-1941) norādīja, ka RABCB darbojies kā komunistu platforma kūdīšanai pret valsti, centrālbirojā un tajā ietilpstošajās arodbiedrībās darbojās komunistu frakcijas, savukārt organizācijā izveidotā sporta sekcija "patiesībā bijusi uzskatāma par bruņotu organizāciju komunistu mērḳu sasniegšanai” (Iekšlietu Ministrijas Vēstnesis 1928, 257, 2). N̦emot vērā visas Rīgas apgabaltiesas rīcībā esošās ziņas RABCB un tajā ietilpstošo arodbiedrību lietā, tika pieņemts lēmums tās slēgt (LNA-LVVA, 3724-1-2940, 55).

\section{SECINĀJUMI}

LKP iefiltrēšanās legālajās organizācijās un jaunu organizāciju dibināšana 20. gadsimta 20. gados norisinājās centralizēti - pēc LKP konferencēs pieñemtas vienotas darbības līnijas, ko organizēja un koordinēja pie LKP izveidots legālā darba organizācijas centrs. RABCB piemērs ḷauj izdarīt vairākus secinājumus par LKP satelītorganizāciju darbību 20. gadsimta 20. gados. LKP savu politiskās darbības līniju RABCB realizēja, tieši komplektējot tā vadību - prezidiju - no nelegālās organizācijas locekḷiem. Lai gan RABCB oficiālais mērḳis bija aizstāvēt strādnieku intereses un veicināt arodkustības attīstību, tā reālās darbības centrā bija LKP noteiktās 
politiskās līnijas realizācija. RABCB visos tās darbības virzienos vērsās pret pastāvošo valsts iekārtu, iestājās par radikāliem risinājumiem sociālajā un politiskajā jomā un ciešiem sakariem ar PSRS. RABCB kā LKP satelītorganizācija nodrošināja nelegālajai organizācijai pieeju plašākām sabiedrības aprindām, sniedza iespēju uzrunāt sabiedrību dažāda veida publiskos pasākumos, izdot un popularizēt legālus preses izdevumus, pieteikt un organizēt streikus, kas tika izmantoti kā vērtīgi instrumenti politiskās aǵitācijas veikšanai. LKP darbībā būtiska bija iespēja ar RABCB starpniecību kandidēt un iegūt mandātus vēlētās valsts institūcijās, ko apliecina centrālbiroja pārstāvētā saraksta sekmīgā dalība Rīgas pilsētas pašvaldības vēlēšanās. Raksturīgi, ka RABCB ietilpstošo arodbiedrību un to biedru skaits pakāpeniski samazinājās. Cēloṇi tam bija centrālbiroja nespēja efektīvi risināt strādniekiem saistošus sociālos jautājumus; organizācijas darbības centrā bija tās politiskās darbības noteicējas - LKP - uzdevumu izpilde, kas, atdalīti no demokrātiskās Latvijas attīstības līnijas, nespēja iekḷauties politiskajā un sociālajā realitātē.

N̦emot vērā RABCB pretvalstisko raksturu, tas pastāvīgi atradās Politiskās pārvaldes u. c. valsts institūciju redzeslokā. RABCB slēgšana 1928. gada 19. jūlijā bija likumsakarīga, jo aiz legālas organizācijas piesega LKP realizēja savu politisko darbību. Lai gan RABCB LKP vadībā veica plašu komunistisko ideju aǵitāciju dažādos tās darbības virzienos, organizācijas darbības laikā reālu iespēju apdraudēt demokrātiskās Latvijas valstiskumu tai nebija, bet demoralizēt un pretvalstiski noskan,ot attiecīgo sabiedrības dalı tā spēja un īstenoja.

\section{SAĪSINĀJUMI}

LABCB - Latvijas Arodbiedrību centrālbirojs

LKP - Latvijas Komunistiskā partija

LKP CK - Latvijas Komunistiskās partijas Centrālā komiteja

LNA-LVVA - Latvijas Nacionālā arhīva Latvijas Valsts vēstures arhīvs

PSRS - Padomju Sociālistisko Republiku Savienība

RABCB - Rīgas Arodbiedrību centrālbirojs

\section{IZMANTOTIE AVOTI UN LITERATŪRA NEPUBLICĒTIE AVOTI}

Rīgas apgabaltiesas administratīvās nodaḷas rezolūcija, 28.11.1928. LNA-LVVA, 37241-2940, 55. lp.

Rīgas Arodbiedrību centrālbiroja paplašinātais prezidija sēdes protokols, 12.01.1925. LNA-LVVA, 3980-1-1, 38. lp.

Iekšlietu ministra ierosinājums par "Rīgas arodniecisko biedrību centrālbiroja" slēgšanu, 29.07.1928. LKM, 23044/21707(2)-VII, 1-4. lp. 


\section{PUBLICÉTIE AVOTI}

Kuduma, A. (red.). Latvijas Komunistiskās partijas kongresu, konferenču un CK plēnumu rezolūcijas un lèmumi. 1. daḷa. 1904-1940. Rīga: Latvijas Valsts izdevniecība, 1958.

Latvijas Republikas I Saeimas stenogrammas, 2. sesija [1923]. Rīga: Latvijas Republikas Saeima, 313.-314. sl.

Likums par biedrībām, savienībām un politiskām organizācijām, 1923. Likumu un Ministru kabineta noteikumu krājums, nr. 12. Rīga: Tieslietu ministrijas Kodifikācijas departaments. 196-198.

\section{PRESE}

Apturēta 13 kreiso arodbiedrību darbība, 1928. Latvijas Kareivis, 166, 3.

Arodnieciskās biedrības, 1920. Arodnieks, 1, 6.

Brikškis, O. Latvijas strādnieku šā gada saimnieciskie streiki, 1928. Jaunais Laiks, 5, 157-161.

Par pretvalstisku darbību slēgtas biedrības, 1928. Iekšlietu Ministrijas Vēstnesis, 257, 2.

Rīg. Arodbiedrību Centrālbiroja rezolūcija par strādniecības vienotu fronti, 1922. Darbs un Maize, 5, 151-153.

Rīgas Arodn. biedr. centrālbiroja gada sapulce, 1922. Arodnieks, 8, 7 (67).

Rīgas arodu biedrību centrālbiroja, strādnieku kooperācijas darbinieku un 1. dzīvokḷu īrnieku savienības vēlēšanu platforma Rīgas pilsētas domes vēlēšanās, 1922. Darbs un Maize, 4, 119-123.

Rīgas pilsētas domes arodnieku frakcijas deklarācijas domes sēdē 6. aprīlī 1922. g., 1922. Darbs un Maize, 6, 184-185.

\section{ATMIṆAS}

Lācis, A., 1961. Tikšanās ar Leonu Paegli. Paegle-Frankēvica, O. (sast.). Atminnas par Leonu Paegli. Rīga: Latvijas Valsts izdevniecība, 133-142.

Ozoliņš, V., 1983. LKP CK Legālais centrs (1922-1924). Priede, P. (sast.). Revolucionārā Rìga pagrīdes cīnā. LKP Rīgas organizācijas nacionālistiskās buř̌uāzijas diktatūras laikā (1920-1940). Atmiņu un materiālu krājums. Rīga: Avots, 177-179.

\section{LITERATŪRA}

Arnte, A., 1964. Latvijas Komunistiskā partija - kreiso arodbiedrību cīṇas vadītāja par strādnieku šķiras vienību (1920-1929). Rìga: Pētera Stučkas Latvijas Valsts Universitāte.

Bērziņa, A., Vāveris, G., 2020. Drošības dienests starpkaru Latvijā, 1918-1940: vēsture. Rīga: Valsts drošības dienests.

Kapeniece, I., 1981. Ciešā un prasmīgā saistībā. LKP pieredze nelegālā un legālā darba savienošanā laikā no 1920. līdz 1934. gadam. Rīga: Avots.

Kipers, J., 1970. Arodbiedrību revolucionārā prese. Līdace, E. (red.). Nost važas! Raksti un atminas par Latvijas Komunistiskās partijas vadito kreiso arodbiedrïbu revolucionāro ciṇu buržuāziskajā Latvijā (1920-1934). Rīga: Liesma, 73-87.

Krūmiņš, Ā., Pupurs, J., 1970. Kreisie arodnieki Rīgas pilsētas domē. Līdace, E. (red.). Nost važas! Raksti un atmiņas par Latvijas Komunistiskās partijas vadìto kreiso arodbiedrību revolucionāro cīnu buržuāziskajā Latvijā (1920-1934). Rīga: Liesma, 59-72. 
Kundziņš, K., 1972. Latviešu teātra vēsture. 2. sējums. No 20. gs. sākuma līdz 1940. gadam. Rīga: Liesma.

Mednis, I., 1998. Galēji kreiso politisko partiju darbība Latvijas Republikas parlamentārajā periodā. Latvijas Arhìvi, 2, 31-35.

Rīgas pilsētas gada grāmata 1931. gadam: 1. gadagājums, 1931. Rīga: Rīgas pilsētas valdes izdevums.

Strādnieku laika grāmata 1925. gadam, 1925. Rīga: R.A.B. Centrālbirojs. 


\title{
SATELLITE ORGANIZATIONS OF THE LATVIAN COMMUNIST PARTY IN THE 1920s: EXAMPLE OF RIGA TRADE UNION CENTRAL BUREAU
}

\author{
GUNA PLAKANE \\ Mg. hist., doctoral student at the Faculty of History and Philosophy, \\ University of Latvia; researcher at the National History Museum of Latvia \\ E-mail: guna.plakane@Invm.Iv
}

\begin{abstract}
The most significant radical left-wing organization supported by the USSR in interwar Latvia was the Latvian Communist Party (LCP). The LCP operated legally in the USSR, while in Latvia it was forced to function covertly. One of the activities of the underground communists was to infiltrate legal organizations, as well as to establish formally independent organizations that were politically dependent on the party. The article provides an insight into the activities of the LCP's satellite organizations in the 1920s, using the example of the Riga Trade Union Central Bureau. The organization was opposed to the Latvian state, advocated radical solutions in the social and political sphere and close ties with the USSR. The Central Bureau provided a legal opportunity to spread the propaganda of the illegal organization to the general public.
\end{abstract}

Keywords: Latvian Communist Party, Riga Trade Union Central Bureau, public organizations, satellite organizations, communists.

\section{SUMMARY}

The most significant radical left-wing organization in interwar Latvia was the Latvian Communist Party (LCP). The USSR played an important role in the activities of the LCP, as it purposefully organized and financed communist movements which undermined the domestic security of Latvia and other countries in the region. The LCP operated legally in the USSR, while in Latvia it was forced to function underground. One of the activities of the communists was to infiltrate legal organizations, as well as to establish formally independent organizations that were politically dependent on the party.

One of the most important LCP's satellite organizations was the Riga Trade Union Central Bureau (RTUCB), which from 1924 until its closure in 1928 operated as its centre of legal activity. The example of RTUCB's 
activity allows to draw several conclusions about the main characteristics of LCP's satellite organizations. The LCP carried out its political activities directly in the RTUCB, recruiting its leadership from amongst members of the illegal organization. The organization was opposed to the Latvian state, advocated radical solutions in the social and political sphere and close ties with the USSR.

The RTUCB provided the illegal organization with access to the general public, to publish and promote legal press, to announce and organize strikes, which were used as valuable tools for political agitation. An important operation of the LCP was the opportunity to run in elections and obtain seats in state electoral institutions through the RTUCB. Typically, the number of trade unions and their members in the RTUCB gradually decreased. The reason for this was the inability of the Central Bureau to effectively address social issues that affected workers, as it mostly focused on political activities coordinated by the LCP.

Due to the anti-state nature of the RTUCB, it was monitored by the Political Department. The closure of the RTUCB on July 19, 1928, was consequential, as the LCP carried out its political activities behind a legal organization. Although the RTUCB, under the leadership of the LCP, campaigned extensively for communist ideas in various ways, it had no real opportunity to threaten Latvian statehood. 


\title{
IDENTITY OF KAUNAS INHABITANTS: MEMORIES OF THREE GENERATIONS
}

\author{
KARINA RAČAITYTÉ \\ Doctoral student (ethnology), Vytautas Magnus University \\ E-mail: karina.racaityte@gmail.com
}

\begin{abstract}
The aim of this paper is to determine the identity of three generations of Kaunas inhabitants. Kaunas is the second biggest city in Lithuania. During the Soviet occupation, new districts such as Dainava, Kalniečiai, Eiguliai and Šilainiai were built. This paper is based on A. Assmann's theoretical approach to communicative memory. Empirical material was collected using field research methods: in-depth, semi-structured interviews. 115 narratives were analysed, employing comparative, retrospective, narrative analysis methods. The results of this research suggest that narratives of communicative memory can help to create cultural identity related to specific urban places or the ones displaced from these places.
\end{abstract}

Keywords: communicative memory, cultural identity, identity, narratives, generational memory.

\section{INTRODUCTION}

After the Second World War, the number of inhabitants of Kaunas city started to grow with the development of the industry. New employees of industrial companies had to be settled in the locations of production. Therefore, new neighbourhoods of Kaunas were designed and their construction started in the 1960s. The neighbourhoods of Dainava, Kalniečiai, Eiguliai, Šilainiai were different from the historic neighbourhoods of Kaunas city in that they were built in mostly empty spaces: in the fields or territories of former villages or settlements in the suburbs. Very little trace of 
old inhabitants remained in the new neighbourhoods, since the majority of people moved out from the villages, their buildings were demolished. In 2019, 144281 permanent inhabitants, i.e., $50.31 \%$ of all inhabitants of Kaunas (in the beginning of 2020, 289380 permanent inhabitants were living in Kaunas city $)^{1}$ lived in the districts of Dainava, Kalniečiai, Eiguliai of Kaunas city. The inhabitants of these neighbourhoods encountered social and cultural problems, such as uncertain identity, memories related to traumatic experiences present at all levels of memory (individual, communicative, cultural memory). Analysing the narratives of people from Kaunas, it was noticed that respondents who were of a similar age had coincident memories, their narratives had kindred features of structure and content. This paper addresses the following problem: how the individual, communicative and cultural memory is reflected in the narratives of the inhabitants of Kaunas? Can those narratives be "used" for construction of the identity of a respondent? The object of the research are the narratives of the inhabitants from Dainava, Kalniečiai, Eiguliai, Šilainiai districts of Kaunas city. The aim is to establish the identities of three generations of Kaunas inhabitants. In order to achieve the aim, the following goals were set for the current study: to analyse the narratives of the inhabitants of Kaunas and to determine their characteristic features; to distinguish narratives that belong to the level of communicative memory; to establish how these narratives are used by respondents to construct their identities. Although the field of this study was comprised of four selected Kaunas microdistricts, the analysis of the ethnographic research material revealed that there were no significant or critical differences between stories of the residents from these four Kaunas districts. However, differences emerged between the stories of respondents from different age groups. Results of the study showed that respondents chose different methods to construct their identities, and their identities were not just urban. These identities could be various, related to parts of the city or displacement from the city, pertaining to lifestyle or the place of origin. Therefore, the study aims to establish the identity of three generations of Kaunas residents, which is a broader concept than urban identity.

This paper is based on the analysis of ethnographic fieldwork material. Ethnographic material was collected in 4 districts of Kaunas - Dainava, Eiguliai, Kalniečiai, Šilainiai - in 2017-2020, using an ethnographic questionnaire "Changes of urban identity of the inhabitants of Kaunas in the middle of the $20^{\text {th }}$ century - the beginning of the $21^{\text {st }}$ century" prepared by the author of this paper. In order to reflect the cultural environment and

${ }^{1}$ The Lithuanian Department of Statistics, portal of official statistics. Available at: https://osp.stat.gov.lt/infografikas-kaunas-2020 (last viewed July 15, 2020). 
the variety of people living in the districts, no special criteria regarding the ethnicity or social status were put forth before the research; however, criterion of age was applied (only those older than 18 were interviewed). The respondents were born from 1930 to 1996.115 respondents who were born in Kaunas or had moved to Kaunas from smaller towns, were interviewed by the method of in-depth interview and semi-structured interview. 69 respondents were female, 46 respondents - male. 21 respondents had acquired secondary education, 8 had special secondary (vocational) education, 22 had higher education, 63 had university education. Empirical material was analysed using comparative and retrospective methods. The excerpts of interviews presented in this paper have not been edited, so as to reveal the authenticity and style of their speech. Narrative and narrative analysis terminology is used in the article. The narrative is understood as a logically structured sequence of events pertaining to a particular story (Hawthorn 1998, 209). Narrative analysis is a research strategy which puts forth that when specific stories are told, they provide insights into the experiences of the people (Bitinas, Rupšienè, Žydžiūnaitè 2008, 303).

While analysing the narratives of the respondents during interviews, certain patterns were noticed within the narratives of certain age groups. Narrative analysis showed that even individuals from different age groups could have similar experiences relating to the general time period, as their everyday lives at the time shared common themes. Memorable events (in the world, country, city, district or personal life) also form a part of their memory. According to the theory of Karl Mannheim, socio-political events have the greatest influence and cause the biggest impact on an individual at the age of 12 to 22 . This creates generations with different experiences of their childhood and teenagehood (Mannheim 1952). A generation is not a homogeneous group: people who belong to the generation can have different education, belong to different social classes. Not every generation shares a consciousness or identity belonging to their generation (Mannheim 1952). The problem of generational barriers and their definition is relevant and still discussed in theoretical scientific literature. Sociologists use the term of cohort generation in order to describe the groups of people who belong to different age groups. Cohort generation is a group of the same or similar age, connected by mutual historical experiences, on the basis of which a specific mentality of the group is formed, distinct from other similar groups (Miller 2000, 30). According to S. Kraniauskiene, an individual identity "[..] is understood in social theory as a unique and authentic self-awareness acquired by an individual" (Kraniauskiene 2004, 41). It is important to emphasize that both individual and collective identities are formed in communication with others (family members, neighbours, classmates or colleagues), thus, a person 
re-establishes his identity. This paper claims that in the present postmodern world an individual can have more than one identity. These identities can be both equally expressed and important or have differing levels of importance to the respondent.

The theoretical approach of memory by J. and A. Assmann is applied in the article (Assmann 2008). J. Assmann singles out three types of memory: individual, communicative and cultural that can be reflected in the narratives. According to A. Assmann, "communicative memory is formed through regular conversation with other people and through common experience. [..] Communicative memory embraces a period of 80-100 years, i.e., three to five generations" (Assmann 2013, 43-44). The author of this article refers to generational cohorts according to K. Joesalu (Joesalu 2017), and adds a new generational cohort based on the current research those born during the restoration of independence. K. Joesalu analysed narratives of different generations in Estonia and distinguished three generations that lived during the Soviet era: those who were born in the 1920s, 1940s and 1970s (Joesalu 2017). She also examined the narrated experiences of different generations from a theoretical point of view, based on J. and A. Assmann and K. Manheim. This paper does not discuss respondents who were born in the 1920s because the number of their interviews is small, not many members of this group have survived.

Sociologists, ethnologists and political scientists studied the communicative and cultural memory narratives in Lithuania and their influence on the processes of identity formation. I. Šutiniene has studied the peculiarities of Soviet-period collective memory traits forming in modern society (Šutinienè 2003), questions of social memory, connections of biographical narratives and identity in the late modern society (Šutiniene 2008, 111). L. Vervečkienè analysed the Soviet narratives of three generations - grandparents, parents and grandchildren - looking for a "generational gap" and its traits (Vervečkienè 2019). D. Leinartè studied how the members of various generations remember the Soviet period (Leinartè, Žilinskienè, Kraniauskienė, Šutinienė, Gečienė 2014). L. Žilinskienė analysed the memories from the intergenerational aspect (Žilinskienè 2015, Žilinskienè, Kraniauskienè, Šutinienè 2016). R. Račiūnaitė-Paužuolienè and G. Matusevičienè examined the narratives of three generations of Lithuanian women in exile, values reflected therein and experiences of repression (Račiūnaitè-Paužuolienè, Matusevičienè 2017, 2018). While discussing memory narratives, it is important to mention the prevailing traumatic experiences. Beyond influencing the lives of the people who suffered from those experiences directly, they also influence their descendants (Vaskelienè, Kazlauskas, Gailienè, Domanskaitè 2011; Gailienè 2008). 


\section{“WE DIDN'T SEE MUCH OF A LIFE": THE FIRST SOVIET GENERATION OR SILENT GENERATION - BORN IN 1940s}

In this group, K. Joesalu includes the people born from the late 1930s until the first half of the 1950s. She quotes Wulf, who describes this group as "post-war children" (2016) (Joesalu 2017, 34). This generation of respondents was distinguished and defined according to the features of narratives characteristic to the members of this age group, the content and form of narratives. The age and historical events reflected in their memories are amongst the main criteria that enable distinguishing of the respondents who belong to this age group. They were born in the interwar period before the $2^{\text {nd }}$ World War, during the war, or after it. Difficulties and painful experiences, also living conditions after the war are vividly reflected in their memories. This historical period was characterised by the threatening circumstances and corresponding living conditions. Researchers who analysed the narratives of women - survivors of exile, noticed that common experiences shared during the after-war period united respondents of different ages: "[..] the difference in women's age did not have any influence on the identity of exiles. All respondents shared similar experiences suffered in exile" (Račiūnaitè-Paužuolienė, Matusevičienė 2017, 258).

A woman, who was born in historical Žaliakalnis district in 1937 and later lived in the district of Dainava, describes life after the war:

"It was a post-war period [..] it was very difficult for everyone, [..] all the neighbours, how to say, lived like a family: we shared what we had despite the fact that everyone was afraid of each other. To some extent, people were afraid of being reported until 1951, 1954 probably [..] From about 1960s, people, youth actually started to recover. Those factories opened up [..]. There was more work [..]" (VDU ER 2669/9).

Close relationship of assistance among the neighbours partly compensated insecurity which prevailed during the interwar period. However, one could not feel safe even around these people. More than one identity is exposed in the memories of the respondent. In the narrative the woman constructs her identity through obvious, measured criteria and criteria treated as "objective" such as the place of birth, the origin of her parents and grandparents:

"[I $\mathrm{am}]$ an inhabitant of Kaunas, a Lithuanian, and an inhabitant of Žaliakalnis, since Žaliakalnis is both my native place and home. Everything in one place. Actually, my mother and my grandparents are practically from Kaunas. [..] I just know as little as this. I do not know any surnames of my great grandparents, nothing. Somehow, I'll say it like this, we lived in a generation where everything was suppressed. [..] Survival was all that mattered. [..] My mother was just fifteen years old when her parents died. I have, definitely, asked my mother about them but she never told anything 
and I don't even know why. Sometimes I thought that we didn't know how to talk openly, so she could tell" (VDU ER 2669/9).

During the Soviet era the history of the relatives, their origin was not bravely spoken of in families. It was not spoken of because, according to the respondent, there were more important concerns: "to survive, live". Also, an assumption can be made that the mother of the respondent did not talk with her daughter about her parents who died early, because those themes were painful, sad and unpleasant. In order to discuss those themes, one needed to confront the pain and things that were hidden even from the closest members of the family. Ethnologists, who examined the narratives of lives of women in exile who had suffered traumatic experiences, noticed that those experiences "had negative impacts on those women's personalities: led women to closedness, formed a complex of inferiority" (Račiūnaitė-Paužuolienè, Matusevičienè 2018, 300). The impact of traumatic experiences on personality and the environment which restricted the ways to express thoughts - a combination of those two factors was the cause why the respondents of this generation were not willing to speak about their experiences.

During the analysis of the narratives of respondents, it was noticed that memories of difficulties, dangers, insecurity and the aim to survive prevailed both on the level of individual and communicative memory. Specific individual and collective identities were formed concerning repressions of totalitarian rule, as well as missed childhood and teenage years (specific to certain areas), place of birth, place of residence or origin of the families.

\section{THE LAST SOVIET GENERATION - BORN IN THE 1970S}

According to K. Joesalu, these respondents were born in the years of late socialism, most of them acquired an education in the Soviet system, those born at the beginning of the decade already started their work life in the late 1980s. Their coming of age coincided with great structural changes in society [..]. In the new society that had opened up, there were, on the one hand, several new opportunities to shape one's life trajectories, while, on the other hand, social structures supporting their entry into adulthood were missing. (Joesalu 2017, 35) The most significant historical events for these respondents were the freedom of movement and the restoration of independence. As young adults, these people underwent the social, cultural, and economic changes that took place after 1990.

The second generation, which was defined during analysis of narratives reflecting respondents' memories, was born during the mature Socialism period. This generation has been singled out and selected according to the 
features of the content and structure of their narratives that are analysed in this section. Their parents were suspicious, cautious and practical people, the main goal during the post-war period was to survive. These respondents were born during the period of political and economic thaw which started in the Soviet Union after the death of J. Stalin. When they grew up, more opportunities to study and travel in the Soviet Union emerged. Although sparse, cultural news from the Western world, such as rock and jazz music, Western magazines, fashion trends, ideas and lifestyle of the hippie subculture reached the members of this generation. The Western world was appealing, although it could not be reached easily. For some people, the interest in Western culture was a specific form of cultural resistance. According to E. Ramanauskaitè, who researched alternative movements popular among the youth in the second half of the $20^{\text {th }}$ century, "The Western youth trends came with music. In terms of anthropology, it is the consequence of enculturation." (Ramanauskaitè 2003, 141) E. Ramanauskaitè refers to J. Kristeva and states that at that time youth "rebelled against authorities, political parties, institution, social coercion and against monopolisation of cultural taste, against "parents' culture"" (J. Kristeva 2002, quoted from Ramanauskaite 2003, 129). Of course, not all the teenagers and young people who lived at that time were interested in the alternative culture, not everyone listened to rock music, wore long hair or participated in the resistance movement. However, even those, who did not participate in the activities directly could feel more freedom in public space.

During the interviews, Soviet ideology prevailed at the levels of personal memories (especially pleasant childhood memories, leisure activities with the friends), also in the layers of memories related to historical era. These respondents were talking more about their friends, leisure and hobbies, the theme of hard work and suffering being less common. This could be the result of a certain economic stability and the common narratives of progress.

A woman born in 1958, who lived in her own house in Šilainiai district, told the interviewer that her whole life went on in the city centre and that she came back home for only to rest. She emphasized her aim to be free, independent.

"[..] I would single out the period when I became a student. All the horizons opened to me then, when I became a free person. [..] I didn't like school [..]. I saw it as a prison of prisons and didn't like it at all. [..] [while studying in the university] nobody persecuted, controlled, and that was the most important thing to me. [..] I received a scholarship of 40 roubles and nobody took the money from me, I could do what I wanted with it (VDU ER 2669/6).

Another respondent (woman born in 1974 and living in the Dainava district) highlights the duality of her identity. According to her, she is 
perceived as an inhabitant of a city by the local villagers, while being a villager in the eyes of the city people. Some of these respondents called themselves the citizens of the world, they did not want to relate themselves to some specific geographical place. As most of their parents, the respondents from this age group also have memories about traumatic life experiences, duality of Soviet life. The respondents who had arrived to Kaunas from smaller towns and villages or who had close relatives that were not from Kaunas, can also have a bicultural identity.

\section{BORN DURING THE RESTORATION OF INDEPENDENCE}

This generation has been defined without referring to K. Joesalu's generational cohorts. Changes in lifestyle in independent Lithuania were reflected in the content of their narratives. The majority of respondents are living in the districts since their birth. During the analysis of the narratives of the members of this generation, also in order to distinguish them from other narratives, it was noticed that "the boundaries of generations" were not completely clear. Even the older respondents who were born at the beginning of 1980s could have some features of this generation. The respondents of this generation were born approximately in 1980-1996. During their life, they have seen the most important historical events - the Restoration of Independence of Lithuania or lived after these events. During their early lives, they already inhabited a different political and economic system, had free media and non-ideologized education, an entirely different environment than the one of their parents. The narratives from the level of individual memories are common to respondents. There are less or even no narratives about the Soviet era. It is important to notice that those changes are not always verbalized, not always expressed as a contrast to previous or future times.

Images of personal life prevail in the 28-year-old man's narratives about life in the Kalniečiai district from his very birth in 1992. In the narratives, he emphasized the relationship between people, accidents in the district, daily life: "The best things that I remember are when you didn't say "bye" to your friends and said "see you tomorrow" because you knew you will see them tomorrow [..]. 1990 and 2000, 2001 was a period when we were not grown up yet and the neighbourhood was very important for us. The territories were divided in our childhood. Those who lived in Kalniečiai could not go to Eiguliai and vice versa. And grownups were very busy: work, work, always took care of children, collected from kindergarten, but I didn't see life of a grown up at that period of my early life" (VDU ER 2669/107).

It seems that active participation in the social life of the district; childhood which was spent in the neighbourhood helped to create an identity 
related to his place of residence for this respondent. The respondent considers himself to be an inhabitant of Kaunas, as well as a part of the district: "Yet, by all means, I am the creator of my living place. I like living here, I like being here rather than anywhere else. I know that I will live in this district in the future, either in my own house or a flat. First of all, I am a part of the district [..] I also consider myself to be an inhabitant of Kaunas" (VDU ER 2669/107).

The respondents called themselves Lithuanians, inhabitants of Kaunas, also considered themselves a part of the district. Some of these respondents did not want to relate themselves to some specific geographical place. These respondents could have a displaced and/or bicultural identity. During the analysis of the narratives of respondents, it was noticed that both in the level of individual memory and in the communicative memory, the memories of an individual level of life in the district and communication with others prevail. Respondents who had spent their childhood and teenage years in the same district often tended to link their identity with the district they lived in.

\section{CONCLUSIONS}

Analysis of the fieldwork material revealed that the narratives of respondents from different age groups had different features in both form and content. Having analysed the narratives, it was concluded that the "boundaries" of a generation should be described according to the sets of memories existing at the levels of communicative and cultural memories but not according to the year of birth.

The identity in the narratives of the members of the post-war generation is usually constructed in accordance with "objective" criteria, such as a place of birth and living place, the origin of parents and grandparents, nationality and language. Those identities are common to the second group of respondents, who have been born during the of mature Socialism period. However, this generation is different from their parents since they also have identities related to the memories of individual level and also bi-cultural identities and identities separated from the specific geographical places. The memories that belong to the level of individual memory are common to the narratives of members of the generation of the Restoration of Independence. These respondents are characterized by various types of identities: related to the place of birth or living place, origin, language, nationality, and global identities. It was noticed that those respondents who had spent childhood and teenage years living in one if the districts tended to relate their identity with the district more often. 


\section{SUMMARY}

The aim of the current paper is to determine the identity of three generations of Kaunas inhabitants. Kaunas is the second biggest city in Lithuania. During Soviet occupation, new districts as Dainava, Kalniečiai, Eiguliai and Šilainiai were built. The inhabitants of these neighbourhoods encountered social and cultural problems such as uncertain identity, memories related to traumatic experiences present at all levels of memory (individual, communicative, cultural memory). Having analysed the narratives of people from Kaunas, it was noticed that the respondents who were of a similar age had similar memories, their narratives had coincident features of structure and content.

This paper is based on A. Assmann's theoretical approach to communicative memory. Empirical material was collected in Kaunas using field research methods: interview, in-depth, semi-structured interviews. 115 narratives were analysed, using comparative, retrospective, narrative analysis methods.

Having analysed the narratives, it was concluded that the "boundaries" of a generation should be described according to the sets of memories existing at the levels of communicative and cultural memories but not by year of birth. The respondents from different age groups had similar experiences and shared stories about them with other people from their environment. The results of this research suggest that narratives of communicative memory can help to create cultural identity, related to (or displaced from) certain parts of the city.

\section{SOURCES}

VDU ER - Ethnology Archive of Vytautas Magnus University, Department of Culture studies, B. 2669. Ethnographic material collected by K. Račaityte 2017-2020 in Kaunas.

\section{BIBLIOGRAPHY}

Assmann, J., 2008. Communicative and Cultural Memory. Cultural Memory Studies: An International and Interdisciplinary Handbook. Berlin, New York.

Assmann, A., 2013. Między historią a pamięcią: antologia. Warszawa: Wydawnictwa UW. 2013.

Bitinas, B., Rupšienè, L., Žydžiūnaitè, V., 2008. Kokybinių tyrimu metodologija, Klaipèda: S. Jokudžio leidykla.

Gailienè, D., 2008. Ka jie mums padarè? Lietuvos gyvenimas traumu psichologijos žvilgsniu. Vilnius: Tyto alba.

Hawthorn, J., 1998. Moderniosios literatūros teorijos žinynas. Vilnius: Tyto alba.

Jenkins, R., 1996. Social Identity. London: Routledge. 
Joesalu, K., 2017. Dynamics and Tensions of Remembrance in Post-Soviet Estonia: Late Socialism in the Making. Doctoral dissertation. Tartu: University of Tartu Press.

Kraniauskienė, S., 2004. Identiteto tyrimo metmenys: kartų identiteto paieška XX a. lietuvių autobiografijose, Sociologija. Mintis ir veiksmas, 2, 40-52.

Kristeva, J., 2002. Revolt, she said. An interview by Philippe Petit. London: Semiotext(e).

Leinartè, D., 2008. Prijaukintos kasdienybès. Biografiniai Lietuvos moteru interviu, 19451970 m. Vilnius: Vilniaus universiteto leidykla.

Leinartè, D., 2010. Adopting and Remembering Soviet Reality: Life Stories of Lithuanian Women, 1945-1970. Amsterdam, New York: Rodopi/BRIL.

Leinartė, D., Žilinskienė, L., Kraniauskienė, S., Šutinienė, I., Gečienė, I., 2014. Sovietmečio atmintis gyvenimo istorijose. Vilnius: Vilniaus universiteto leidykla.

Mannheim, K., 1952. [orig. 1928] The problem of generations. Essays on the Sociology of Knowledge. NY: Oxford Univ. Press: 276-320.

Miller, R. L., 2000. Researching Life Stories and Family Histories. London: Sage.

Račiūnaitė-Paužuolienè, R., Matusevičienè, G., 2017. The repressive experiences of Lithuanian women deportees in their life histories: the expression of identity and values. Perspectives of Baltic philology III. J. Niewulis-Grablunas, J. Prusinowskiej, J. B. Walkowiak (red.). Poznań, 255-267.

Račiūnaitė-Paužuolienè, R., Matusevičienè, G., 2018. Lietuvių tremtinių moterų vertybès gyvenimo istorijose. LITUANISTICA. 64 (114), 294-302.

Ramanauskaitè, E., 2003. Jaunimo kultūrinè rezistencija sovietmečiu: hipių kultūrinès idejjos Lietuvoje. Kauno istorijos metraštis. 4, 127-163.

Šutinienè, I., 2003. Sovietinio laikotarpio atminties bruožai autobiografiniuose pasakojimuose. Krukauskienè, E., Šutinienè, I., Trinkūnienè, I., Vosyliūtè, A. Socialine atmintis: minejimai ir užmarštys. Vilnius: Eurgimas.

Šutinienė, I., 2008. Socialinė atmintis ir lietuvių tautinè tapatybė. V. Čiubrinskas, J. Kuznecovienè, Lietuviškojo identiteto trajektorijos. Kaunas: Vytauto Didžiojo universitetas.

Šutinienè, I., 2013. Komunikacinè atmintis Lietuvos didžiuosiuose miestuose. Nikžentaitis, A. Atminties daugiasluoksniškumas: miestas, valstybè, regionas. Vilnius: LII leidykla.

Šutinienè, I., 2015. Tautos istorijos pasakojimo raiška daugiakultūrèje aplinkoje: Pietryčių Lietuvos lenkų etninès grupès atvejis. Sociologija. Mintis ir veiksmas. 2015/2(37), 85-105.

Vaskelienè, I., Kazlauskas, E., Gailienė, D., Domanskaitė G. V., 2011. Komunikacija apie patirtas politines represijas šeimoje: tarpgeneracinis aspektas. International Journal of Psychology: A Biopsychosocial Approach / Tarptautinis psichologijos žurnalas: biopsichosocialinis požiüris. 9, 91-104.

Vervečkienè, L., 2019. Pabrèžta, nutylèta, pateisinta: „kartų efektas“ senelių, tėvų ir anūkų sovietmečio atmintyje. Politologija. 4 (96). 8-37.

Wulf, H., 2016. Shadowlands. Memory and History in Post-Soviet Estonia. London, New York: Berghahn.

Žilinskienè, L., 2015. Šeimos atmintis. I. Juozeliūnienė, J. Seymour. Šeiminiai pokyčiai atviru Europos sienu ir globalaus mobilumo akivaizdoje: resursai, procesai ir praktikos. Vilnius: Vilniaus universitetas.

Žilinskienè, L., Kraniauskienė, S., Šutinienè, I., 2016. Gimę socializme: pirmoji sovietmečio karta. Vilnius: Vilniaus universiteto leidykla. 


\title{
KAUṆAS IEDZĪVOTĀJU IDENTITĀTE: TRĪS PAAUDŽU ATMIṆAS
}

\author{
KARINA RAČAITĪTE \\ Vītauta Dižā Universitātes (Kauṇa) doktorante \\ E-pasts: karina.racaityte@gmail.com
}

\section{KOPSAVILKUMS}

Šĩ raksta mērkis ir noskaidrot trīs paaudžu Kauņas iedzīvotāju identitāti. Kauña ir otrā lielākā Lietuvas pilsēta. Padomju okupācijas laikā tika uzcelti jauni rajoni - Dainava (Dainava), Kalnieči (Kalniečiai), Eiguḷi (Eiguliai) un Šilaiņi (Šilainiai). Šo rajonu iedzīvotājus skar gan sociālas, gan kultūras problēmas: neskaidra identitāte un ar traumatisku pagātnes pieredzi saistītas atminnas visos atmiņu līmeņos (individuālajā, komunicētajā un kultūratminnas). Analizējot Kauņas iedzīvotāju stāstus, ir redzams, ka līdzīga vecuma respondentiem ir līdzīgas atminas, viņu stāstos ir līdzīgi atsevišḳi strukturāli un satura elementi.

Šis raksts ir balstīts Aleīdas Asmanes teorētiskajā pieejā kultūratminai. Empīriskais materiāls ticis savākts Kauņā, izmantojot šādas lauka pētījuma metodes: intervijas, padziḷinātas un daḷeji strukturētas intervijas. Ar salīdzinošās, retrospektīvās un naratīva analīzes metodes palīdzību analizēti 115 naratīivi.

Naratīvu analīze ḷauj secināt, ka paaudzes "robežas" var definēt kā atminu kopumu, kurš pastāv komunikatīvajā un kultūratmiņas līmenī, bet ne pēc dzimšanas gada. Respondentiem no dažādām vecuma grupām bija līdzīga pieredze un kopīgi stāsti ar citiem viniem tuvā vidē dzīvojošiem cilvēkiem. Šì pētījuma rezultāti norāda, ka kultūratmiņas naratīvi var palīdzēt radīt kulturālu identitāti, kas raksturīga noteiktām pilsētas daḷām. 


\title{
NACIONĀLO PARTIZĀNU CĪṆAS VALMIERAS APRIṆK়Ī (1944-1953): ATSPOGULOJUMS LATVIJAS PSR LITERATŪRĀ
}

\section{REINIS RATNIEKS}

Mg. hist., Latvijas Universitātes Vēstures un filozofijas fakultātes doktorants

E-pasts: ratnieksr@gmail.com

\begin{abstract}
ANOTĀCIJA
Rakstā apskatīts Valmieras apriṇ̣̂ī notikušo nacionālo partizānu cīṇu atspoguḷojums Latvijas PSR literatūrā. Padomju okupācijas laikā publicētajos darbos pieejama plaša informācija par bruṇoto pretestību apriṇ̣̂ī, taču tās vēstures aspekti tika interpretēti atbilstoši padomju propagandai, tāpēc ir atspoguḷoti neobjektīvi un nomelnojoši, turklāt aprakstos bieži iekḷauti nepatiesi fakti. Partizānu darbības aprakstos tika izcelta padomju okupācijas režīma darbinieku un aktīvistu nogalināšana, lai radītu priekšstatu, ka partizānu kustība bijusi krimināla rakstura un ar noslieci uz vardarbību, tajā pašā laikā partizānu lietotās nevardarbīgās pretošanās metodes padomju literatūrā ir gandrīz noklusētas.
\end{abstract}

Atslēgas vārdi: nacionālie partizāni, pretošanās kustība, padomju okupācija, literatūra, Valmieras apriṇ̣̂is.

\section{IEVADS}

Nacionālo partizānu cīṇas bija viena no redzamākajām liecībām par Baltijas valstu iedzīvotāju negatīvo attieksmi pret PSRS okupāciju Otrā pasaules kara beigās un pēc tā, tāpēc padomju režīmam tas bija neērts temats. Lai diskreditētu bruṇotās pretošanās kustību, tās darbības vēsture padomju autoru darbos tika sagrozīta. PSRS propagandā nacionālie partizāni tika dēvēti par nacistu atbalstītājiem un noziedzniekiem, ignorējot vinu darbības reālo būtību un motivāciju.

Partizānu darbība Latvijas reǵionos ir samērā maz pētīta, tāpēc PSRS okupācijas laika literatūra, it sevišḳi prese, nereti ir izsmeḷošākais 
informācijas avots par to. Prese bija arī propagandas līdzeklis, ar kuru okupācijas režīms centās iespaidot sabiedrības viedokli, tāpēc pastāv jautājums, cik patiesa ir tajā sniegtā informācija par nacionālo partizānu cīņām. Līdz šim nav publicēti atsevišķi pētījumi par partizānu cīṇu atspoguḷojumu PSRS laika presē, taču šis temats ir nedaudz skarts vēsturnieku Heinriha Stroda un Zigmāra Turčinska pētijumos. Abi vēsturnieki ir vienisprātis, ka nacionālo partizānu vēstures atspoguḷojumam Latvijas PSR literatūrā raksturīgi nekorekti un pat vulgāri vērtējumi, faktu materiāls pakārtots tendencioziem spriedumiem, kuri nereti ir pretrunīgi, turklāt bieži sastopama arī faktu izdomāšana (Strods 1996, 10-12; Turčinskis 2011, 21-22).

Rakstā pievērsta uzmanība Latvijas PSR publicētajai literatūrai par partizānu cīņām Valmieras apriņ̣̂ī - šì literatūra analizēta, lai noskaidrotu, kā tajā tika aprakstīta nacionālo partizānu darbība un cik šajos darbos rakstītais atbilst reālajai vēsturiskajai situācijai. N̦emot vērā to, ka Valmieras apriṇķī partizānu kustība bija mazāk izteikta nekā citviet Latvijā, šis pētījums varētu arī sniegt vispārīgu priekšstatu par to, vai pretošanās kustības raksturs konkrētajā reǵionā ir ietekmējis aplūkoto publikāciju satura veidošanas īpatnības.

Raksta mērkis ir analizēt Valmieras apriņ̧̧a nacionālo partizānu cīṇu 1944.-1953. gadā atspoguḷojumu Latvijas PSR periodikā. Mērḳa sasniegšanai rakstā vispārīgi raksturotas nacionālo partizānu cinnas Valmieras apriņ̧̧ī 1944.-1953. gadā, aplūkota Valmieras apriņ̧̧̧a nacionālo partizānu cīnnu temata atspoguḷojuma attīstība Latvijas PSR periodikā, kā arī veikta tajā ietverto faktu un spriedumu analīze, izmantojot zinātniskajā pētniecībā iegūtos datus un atziņas.

Rakstā izmantotas 18 publikācijas no Latvijas PSR iznākušajiem laikrakstiem un žurnāla (izdoti 1945.-1988. gadā), kur atrodama informācija par pēckara nacionālo partizānu cinnām Valmieras apriṇkịi. Rakstā izmantota aprakstošā, salīdzināšanas un kontentanalīzes metode.

Tā kā zinātniskajās publikācijās ${ }^{1}$ par nacionālo partizānu cīņām Valmieras apriņ̧ī ir visai maz informācijas, reālās situācijas apskatam tā ņemta arī no pirmavotiem, kas izmantoti raksta autora topošajā pētījumā $\bar{a}^{2}$ par partizānu darbību reǵionā - Latvijas Nacionālajā arhīvā pieejamajām Valsts drošības komitejas $(K G B)$ krimināllietām un operatīvās informācijas kartotēkām, kā arī no nepublicētiem atmiṇu stāstījumiem.

Aplūkotajā laikā notika dažas izmaiņas Latvijas PSR administratīvajā dalījumā. Raksta nosaukumā ar Valmieras apriṇki tiek saprasta administratīvā teritorija laikā no 1944. gada līdz 1947. gada 14. oktobrim, pēc kā tā tika sadalīta Valmieras un Limbažu apriņkî. 1949. gada 31. decembra administratīvi teritoriālās reformas rezultātā aplūkotā teritorija tika pārveidota Valmieras, Rūjienas, Alojas un Limbažu rajonā. 


\section{NACIONĀLO PARTIZĀNU DARBĪBA VALMIERAS APRIṆḲī 1944.-1953. GADĀ}

Valmieras apriņ̧is bija reğions ar salīdzinoši mērenu bruṇoto pretestību padomju okupācijas režīmam. Varētu piekrist pieņēmumam, ka to lielā mērā ietekmēja Vācijas un PSRS karadarbības frontes apstāšanās Gaujas līnijā uz dažām nedēḷām 1944. gada augusta beigās (Turčinskis 2011, 26). Neilgais frontes stāvoklis pēdējā brīdī deva laiku bēgt daudziem rietumvidzemniekiem, kuri bija darbojušies vācu okupācijas režìma policijas struktūrās un civilpārvaldē, aizsargu organizācijā vai iesaistījušies jebkādās citās aktivitātēs, kas palikšanas gadījumā represiju draudu dēḷ varēja dot stimulu slēpties. Tādējādi reǵionā potenciālā partizānu dzīvā spēka bāze, visticamāk, kḷuva krietni mazāka.

Lìdz ar apriņ,̧a nonākšanu Sarkanās armijas kontrolē 1944. gada septembrī un tam sekojošo cilvēku pāreju pagrīdē represiju un mobilizācijas Sarkanajā armijā dēl sākās bruṇotu grupu veidošanās, kas izteikti turpinājās līdz 1945. gada vasaras sākumam, kad šādās grupās Valmieras apriṇḳī bija apvienojušās vismaz 113 personas. $^{3}$

Pirmās mežabrāllu un okupācijas spēku sadursmes norisinājās kopš 1945. gada pavasara, kad NKVD Valmieras apriņķa nodaļa sāka aktīvāk meklēt nelegālistus un veidot aǵentūras lietas pret partizānu grupām. Lielākais NKVD panākums līdz vasarai bija pie Salacas upes uzbūvētā bunkurā dzīvojošas piecu partizānu grupas sagūstišana 1945. gada 5. martā Rozēnu pagastā (Ratnieks 2018, 71).

İpašu rezonansi apriņ̧îi ieguva partizānu cīņu notikums 2. maijā Katvaru pagastā, kad grupa bruņotu aktīvistu pagasta partorga Jāṇa Voldiņa vadībā uz aizdomu pamata veica pārbaudi Mežnieku mājās, kur kopš 1944. gada rudens slēpās Skujiṇu gimenes visi trīs dēli un vinu kaimiṇš. Tvarstītāji nebija paredzējuši nopietnu pretestību, un, mēgéinot bēgt no kaujas, J. Voldiņš un istrebiḳeḷ Jēkabs Vìtiņš krita (LNA-LVA, 1986-140468-1, 30).

Ievērojamākā $N K V D$ operācija 1945. gada vasarā notika 28. jūnijā Idus pagasta mežos. Tur čekas ${ }^{4}$ spēki uzbruka septiņu cilvēku lielai mežabrāḷu grupai, ko neilgi pirms tam bija formāli vadījis apkaimes partizānu līderis Eduards Čoka. Operācijā tika nogalināts viens un sagūstīts viens grupas dalībnieks, taču panākums bija tikai simbolisks, jo šì darbības ziñā pasīvā grupa nebija drauds okupācijas režīmam (LNA-LVA, 1986-1-17559-1, 140).

Līdz 1945. gada rudenim notika vairāki partizānu uzbrukumi individuāliem okupācijas režìma darbiniekiem un atbalstītājiem. Tā bija Valmieras apriņ̧̧a partizānu darbības specifika kopš cīṇu sākuma, jo nelielās aktīiās grupas (5-10 cilvēki) neriskēja uzbrukt pagastu centriem, ko 
veica partizānu grupējumi ar vairākiem desmitiem cīnītāju citviet Latvijā. ${ }^{5}$ Ar maziem uzbrukumiem partizāni tik un tā spēja izdarīt psihologisku spiedienu uz okupācijas režìma atbalstîtājiem. Vị̣a Skujiṇa grupa Katvaru un apkārtējos pagastos augustā un septembrī nošāva trīs okupācijas režīma darbiniekus. Jāņa Freimaņa grupa 1945. gada 13. oktobrī Mujānu pagastā nošāva Valmieras apriņ̧̧a komitejas trešo sekretāru Rūdolfu Zarinu, kurš iepriekš bija strādājis čekā, un Valmieras rūpniecības kombināta galveno inženieri Jāni Osi, kurš līdzās saviem tiešajiem pienākumiem veica lauksaimniecības nodevas slēpušo zemnieku uzskaiti apriņkīi To partizāni noskaidroja, pārbaudot abu kolaboracionistu personīgos dokumentus (LNALVA, 1986-1-2023-1, 80; Freimanis 1995, 136-137).

Partizānu darbība neaprobežojās tikai ar bruṇotām akcijām. Piemēram, E. Čokas grupa 1945. gada 15. maijā pie Rūjienas luterāṇu baznīcas izkāra Latvijas Republikas karogu (Ratnieks 2018, 73). Savas pastāvēšanas laikā Oskara Miḳelsona grupa Dikḷu pagastā, J. Freimaṇa grupa Vaidavas pagastā un Pētera Dauguḷa grupa Mazsalacas pagastā nodarbojās ar pretpadomju satura skrejlapu rakstī̌anu un izplatišanu (LNA-LVA, 1986-1-2023-1, 96; 18256, 60; Sārnis 2015, 99-100).

Līdz ar PSRS drošības iestāžu darba reorganizāciju Latvijā 1945. gada nogalē, kas izpaudās gan $N K V D-N K G B$ operatīvo štābu izstrādē, gan aktīvākās karaspēka operācijās partizānu darbības rajonos, mežabrāli cieta ievērojamus zaudējumus (Turčinskis 2017, 118). Līdz ar to turpmākajos gados aktīvās partizānu grupas kḷuva konspiratīvākas un uzbrukumus rīkoja retāk. Mērenās partizānu kustîbas potenciālu apriņ̣īi vājināja okupantu veicinātā legalizācija 1945. un 1946. gadā, kad varas iestādēm padevās vismaz septiņas grupas, kas bija apmēram trešdaḷa no šajā periodā pastāvējušām partizānu grupām apriṇ̣̂ī.

Partizāni cieta nozīmīgus zaudējumus 1948. gada rudenī, kad ar $M G B$ aǵentūru tika sagrauta Skujiņa grupa Katvaru pagastā un Rūjienas-Mazsalacas apkārtnē pastāvējusī Artūra Johansona grupa (Ratnieks 2019, 131-132). Valmieras apriṇ̣̂ī palika tikai trīs aktīvas grupas no visā cīṇu laikā apriṇkī pastāvējušām vismaz astoņām šādām grupām. Bez tām mežos atradās atsevišḳi citu izjukušo grupu partizāni, kuri slēpās pa vienam vai sīkās grupin̄ās un uzbrukumus neveica.

Lìdzịgi kā citviet Latvijāa arī Valmieras apriņkīi 1949. gada 25. marta deportācija veicināja partizānu aktivitātes un skaita pieaugumu. Jaunās mežabrāḷu grupas lielākoties bija pasīvas, bet dažas aktīvās grupas pēc 1949. gada marta kopumā veica vairāk nekā 10 uzbrukumus. Viḷa Sedlenieka grupa divu mēnešu laikā Alojas apkārtnē nošāva trīs padomju aktīvistus (Ratnieks 2019, 128, 131). Pētera Čakša grupa pagastos ap Limbažu, Rīgas un Cēsu apriņ,ăa saskares punktu aplaupija vairākus okupantu atbalstìtājus (LNA-LVA, 1986-1-42555-2, 272-278). 


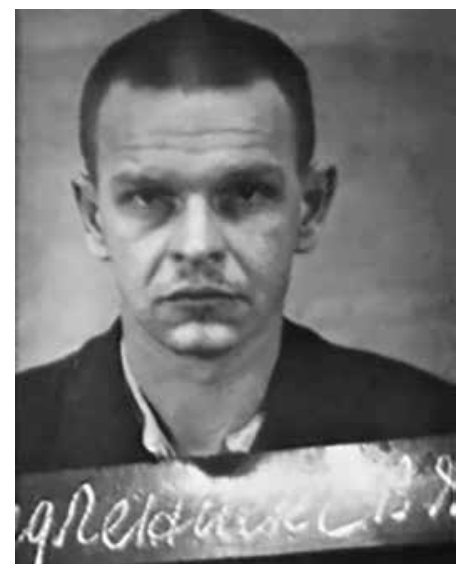

1. attēls. Alojas apkārtnes partizānu grupas vadītājs Vilis Sedlenieks (1923-1951) 1950. gadā apcietinājumā. LNA-LVA, 1986-1-38777

Figure 1. Vilis Sedlenieks (1923-1951), leader of partisan group in vicinity of Aloja, imprisoned, 1950. LNA-LVA, 1986-1-38777

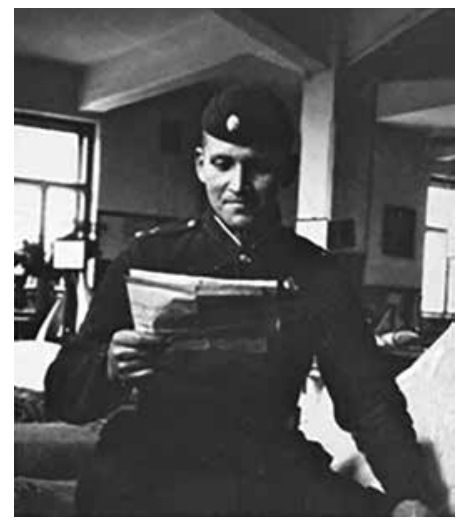

2. attēls. Rencēnu pagasta partizānu grupas vadìtājs Bernhards Zarinšs (1917-1949) 1938. gadā. Ilzes Jarkas privātais arhīvs Figure 2. Bernhards Zarinšs (1917-1949), leader of Rencēni parish partisan group, 1938. Private archive of Ilze Jarka

1949. gadā palikušās partizānu grupas turpināja ciest smagus triecienus. Mēnesi pēc deportācijām tika iznīcināta Bernharda Zariṇa grupa, kuru pie tās bunkura Ēveles tuvumā 1949. gada 30. aprīlī aplenca 66 čekistu liela vienība. Trīs stundu ilgajā kaujā, kas bija lielākā Valmieras apriņ̧̧ī partizānu cīṇu laikā, krita visi četri grupas partizāni, savukārt pretiniekam bija pieci kritušie un viens ievainotais (Strods 1999, 456-459; LNA-LVA, 1825-2-168, 174). 1949. gada nogalē čekistiem bija izdevies atklāt vienu no Sedlenieka grupas ziemošanas vietām Skaņkalnes pagastā. Tur 17. novembrī krita grupas partizāni Jānis Treimanis un Arnis Būmanis (LNA-LVA, 1986-1-38777-2, 226). Čakša grupa cieta zaudējumus 1949. gada maija sākumā, kad tika nošauts viens tās dalībnieks un divi sagūstīti (LNA-LVA, 1986-1-21843, uzraudzības lieta, 359).

Atlikušie Sedlenieka grupas partizāni atbildes uzbrukumā 1950. gada 22. jūlijā Skaņkalnes pagastā nošāva divus istrebikikel̦us. Grupa pārstāja pastāvēt 1950. gada septembrī, kad Limbažu apriņ̧̧a Pāles pagastā čeka sagūstijja pašu V. Sedlenieku (LNA-LVA, 1986-1-38777-1, 10). Grupas partizāns Arvīds Smilškalns tika sagūstīts 1951. gada 1. jūlijā, savukārt pēdējais 
brīvībā palikušais grupas dalībnieks E. Eglītis 1952. gada vasaras otrajā pusē nošāvās mežā pēc ievainojuma gūšanas apšaudē ar pretinieka slēpni (LNA-LVA, 1986-1-28393, 10; Holms 2020).

Sedlenieka grupas iznīcināšana visumā pielika punktu brunotajai pretestībai bijušā Valmieras apriņķa teritorijā. Tiesa gan, pēdējā mežabrāḷ grupa, kurā laika gaitā bija apvienojušies trīs jaunieši vecumā no 19 līdz 21 gadam, pastāvēja Alojas un Limbažu apkārtnē no 1951. gada maija līdz 1953. gada februārim. Divi dalībnieki bija izvairījušies no obligātā dienesta padomju armijā, bet trešais - no darbības $M G B$ aǵentūras tīklā. Cerot, ka Korejas karš pāraugs karadarbībā starp Rietumvalstīm un PSRS, grupa bija sameklējusi ieročus un plānoja pretdarbību okupācijas varai, taču līdz savai sagrāvei tās dalībnieki bez vairāku pretpadomju lapiṇu sagatavošanas lielākoties vienkārši slēpās dažādās viensētās Limbažu un Alojas rajonos un šad tad izdarīja sīkas zādzības pārtikas ieguvei (LNA-LVA, 1986-1-21843-2, 15-65).

\section{VALMIERAS APRIṆḲA NACIONĀLO PARTIZĀNU CĪNU ATSPOGUḶOJUMS LATVIJAS PSR LITERATŪRĀ}

Nacionālo partizānu cīṇu laikā un vairāk nekā 10 gadus pēc tām šo notikumu vēsture visumā bija temats, par kuru nekādas publikācijas nedrīkstēja parādīties. Izṇēmums bija publiskie uzsaukumi partizāniem ar aicinājumu padoties, kā arī komunisma ideolog̣ijā balstītie daiḷliteratūras darbi, kuru funkcija bija padomju režīmam vēlamas izpratnes veidošana sabiedrībā par sociālpolitiskiem jautājumiem. Tajos partizānu cīṇas tika uzdotas par škiru cīņas izpausmi. ${ }^{6}$

Plašāks nacionālo partizānu cīnuu atspoguḷojums literatūrā parādījās līdz ar Otrā pasaules kara komemorācijas uzplaukumu t. s. Brežṇeva periodā PSRS, kā iespaidā arī okupētajā Latvijā tapa publikācijas par padomju reokupācijā iesaistītajiem kara veterāniem un dažādiem aktīvistiem (Ločmele, Procevska, Zelče 2011, 14). 80. gados Padomju Savienībai nelabvēlīgo procesu iespaidā Austrumu blokā un Aukstā kara saasinājuma dēl partijas vēstures institūti PSRS tēla spodrināšanai iedzīvotāju acīs pievērsās līdz tam maz atspogul,otu 20. gs. vēstures tematu skaidrošanai organizētas propagandas kampan̄ā, un starp šiem tematiem bija arī nacionālo partizānu cīñas (Turčinskis 2015).

Fakti par nacionālo partizānu darbību Valmieras apriṇkịi konstatējami kopš 60. gadu beigām publicētajā literatūrā, kad reǵionālajos laikrakstos sāka parādīties publikācijas par dažādiem reǵiona padomju aktīvistiem un varas iestāžu darbiniekiem, taču līdz 80. gadu vidum ziņas par partizānu darbību šajos rakstos bija samērā skopas. Pārsvarā tajos bija raksturīga atsevišķu partizānu akciju minēšana, nesniedzot sīkākas ziṇas par pašiem partizāniem. 
Vērā n,emamas izmaiṇas preses rakstu tematikā parādījās 80. gadu pirmajā pusē līdz ar vēsturnieka un bijušā čekista Jāṇa Dzintara zinātniskajām un populārzinātniskajām publikācijām par nacionālo partizānu darbību

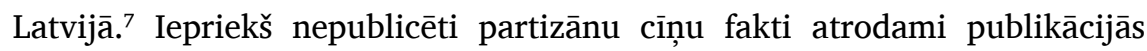
reǵionālajos laikrakstos, tostarp arī par bijušā Valmieras apriņķa nacionālajiem partizāniem, it īpaši kopš 1985. gada, kad tika publicēti galvenokārt tieši partizānu cīnu tematikai veltīti raksti.

Kā ievērojamāko piemēru var minēt 1985. gadā par godu 40. gadadienai kopš nacistiskās Vācijas sakāves Valmierā sagatavoto rakstu krājumu "Upuri apsūdz", kurā bija apkopoti vairāki raksti galvenokārt par nacistu noziegumiem pret civiliedzīvotājiem. Krājumā ietvertajos rakstos "Ik miera pavasaris", "Otrais karš" un "Rencēnos pēc kara” galvenā uzmanība veltīta partizānu cīnu norisēm Valmieras apriṇḳī (Martinovs 1985, 103, 115, 125). "Upuri apsūdz" netika izdots, bet "Ik miera pavasaris" un "Otrais karš" 1985. un 1988. gadā tika publicēti Limbažu un Valmieras reǵionālajos laikrakstos "Progress" un "Liesma", ieviešot publiskajā apritē daudz vairāk jaunas informācijas, piemēram, partizānu un viṇu atbalstītāju vārdus, neminētus partizānu darbības faktus u. tml.

Vadoties pēc iepriekš minētā, rakstus, kuros iekḷauta informācija par partizānu cīṇu notikumiem Valmieras apriṇḳī, tematikas ziṇā ir iespējams periodizēt divās daḷās (sk. 1. tabulu).

1. tabula. Rakstu centrālā tematika

Table 1. Principal topics of articles

\begin{tabular}{|l|c|c|c|c|}
\hline \multicolumn{1}{|c|}{ Rakstu temati } & \multicolumn{2}{|c|}{ Periods } & \multicolumn{2}{c|}{ KOPĀ } \\
\hline & 1969.-1984. gads & 1985.-1988. gads & Skaits & Procenti \\
\hline $\begin{array}{l}\text { Padomju režǐma } \\
\text { darbinieki }\end{array}$ & 9 & 2 & 11 & 60 \\
\hline $\begin{array}{l}\text { Nacionālo } \\
\text { partizānu darbība }\end{array}$ & 1 & 6 & 7 & 40 \\
\hline
\end{tabular}

\section{VALMIERAS APRIṆḲA NACIONĀLO PARTIZĀNU CĪNU FAKTI UN SPRIEDUMI LATVIJAS PSR LITERATŪRĀ}

70.-80. gadu sākumā publicētajos rakstos par dažādiem padomju darbiniekiem ietvertas atsevišḳas partizānu cīṇu epizodes, par kurām informācija n,emta no rakstos aplūkoto cilvēku atmināām. Šajos partizānu darbības aprakstos sastopamas lielas neprecizitātes liecinieku atmiņu kḷūdu un arhīvu avotu nepieejamības dēl. Konstatējami arī izdomājumi un partizānu 
darbības trivializācija, dēvējot viṇus par nevainīgu cilvēku slepkavām, tādējādi mežabrāḷu uzbrukumos bojāgājušās personas, kuras bija līdzatbildīgas par okupācijas režīma saimniecisko un represīvo politiku, ieklāaās propagandas veidotajā mocekḷa diskursā.

Redzamākais piemērs šāda skatījuma veidošanā ir bieži aprakstītā Katvaru pagasta partorga J. Voldin,a bojāeja sadursmē ar Skujiṇa grupu 1945. gadā. J. Voldiņš ir visvairāk pieminētais Valmieras apriņķa partizānu cīņās kritušais - vin,a nāve ir apskatīta aston,os no 18 aplūkotajiem rakstiem un raksturota kā partizānu pastrādāta slepkavība. No tiem sešos rakstos noklusēts, ka J. Voldiņš kritis kaujā pret partizāniem, tādējādi apvienojumā ar jēdziena "slepkavība" izmantošanu partorga bojāeja pasniegta kā partizānu uzbrukuma rezultāts. Laikrakstā "Cīṇa" publicētajā rakstā "Lai tēva gājums turpinātos" lasāms, ka J. Voldiņš nogalināts, kad tīrumā dzinis vagu (Riekstiņš 1984, 2). Visticamāk, šajā gadījumā J. Voldiṇa bojāeja jaukta ar vēlāk uz tīruma nošauto istrebik̦el̦u ${ }^{8}$ Kārli Kalniņu, kurš bija iesaistīts brāḷu Skujiņu aizturēšanas mēǵinājumā, taču šì kḷūda atmiṇās vienlaikus stiprināja J. Voldiņa mocekḷa tēlu.

2. tabula. Rakstos atspogulotā partizānu darbība

Table 2. Partisan activities reflected in articles

\begin{tabular}{|c|c|c|c|c|}
\hline \multirow{2}{*}{$\begin{array}{c}\text { Attēlotā } \\
\text { partizānu darbība }\end{array}$} & \multicolumn{2}{|c|}{ Rakstu temati } & \multicolumn{2}{|c|}{ KOPĀ } \\
\hline & $\begin{array}{c}\text { Padomju } \\
\text { režīma } \\
\text { darbinieki }\end{array}$ & $\begin{array}{c}\text { Nacionālie } \\
\text { partizāni }\end{array}$ & Skaits & Procenti \\
\hline Uzbrukumi & 10 & 33 & 43 & 69 \\
\hline Aizstāvēšanās & 5 & 13 & 18 & 29 \\
\hline $\begin{array}{l}\text { Nevardarbīga } \\
\text { pretošanās }\end{array}$ & 1 & 0 & 1 & 2 \\
\hline
\end{tabular}

1977. gada janvārī laikrakstā "Progress" publicētajā rakstā "Lai salapotu dzīvības koks..." aprakstīta Valmieras apriņ̧̧a istrebiḳeḷu bataljona komandiera vietnieka politiskajos jautājumos seržanta Alekseja Lindiņa it kā notikusī dalība istrebiķel̦u vienības sastāvā operācijā pret B. Zariņa grupu 1949. gada 30. aprīlì. Lai arī kaujas aprakstā atspoguḷoti daži patiesi fakti, tas pārsvarā sastāv no izdomājumiem. Pretēji avīzē rakstītajam $M G B$ atskaitē par kauju norādīts, ka tā bija $M G B$ iekšlietu karaspēka operācija, kurā istrebiḳeḷi netika iesaistīti. Būtiskas neprecizitātes un pārspīlējumi ir arī abu pušu spēku skaitā un kaujas norisē, bet paši mežabrāḷi nievājoši dēvēti par "cilvēka seju pazaudējušiem neliešiem" (Jansons 1977, 2). 
Nozīmīga tendence, kas vērojama šì laika rakstiem un arī turpmāk, ir latviešu tautības aktīvistu cildināšana par viņu darbību padomju režīma stiprināšanā Latvijā, tostarp partizānu apkarošanā, taču noklusēta krievu un citu tautību režìma darbinieku loma, kuri bija lielākā daḷa no drošības dienestu darbiniekiem pēckara gados, savukārt istrebiķ̣elı operatīvajās grupās un iekšlietu karaspēka vienībās bija tikai cittautieši. Tas attiecas arī uz l,oti latvisko Valmieras apriņ,̧i, kura istrebik, elı bataljona štābā iepriekš minētais A. Lindiņš bija vienīgais latvietis, bet visu apriņķa istrebiķel̦u operatīvo grupu komandieri bija cittautieši (LNA-LVA, PA-101-10-75, 40). Tā kā šie raksti bija domāti latviskajai auditorijai, jāsecina, ka šādi okupācijas režīms centās radīt priekšstatu par latviešiem kā nozīmīgākajiem padomju varas aizstāvjiem Latvijā.

Sākot ar 1985. gadu, Valmieras un Limbažu reǵionālajos laikrakstos iekḷautas nozīmīgas publikācijas, kurās ir daudz iepriekš neminētu faktu. Tā paša gada pavasarī Limbažu "Progresā" publicēts raksts "Ik miera pavasaris jāaizstāv" (Taimin,a 1985, 2). Šis bija pirmais raksts ar tik plašu Viḷa Skujiņa partizānu grupas darbības atspoguḷojumu, un tas koncentrējās uz grupas darbību 1945. gadā. Publikācija ir balstīta uz kādreizējā Katvaru pagasta komsorga Ilgvara Pētersona atmiņām, kurš arī piedalījās Skujiņa grupas aizturēšanas mēǵinājumā 1945. gada 2. maijā.

Grupas darbība rakstā atspoguḷota samērā precīzi, lai arī no padomju morāles pozīcijām, taču sastopami daži apmelojoši pieņēmumi intervētā liecinieka attieksmes un zināšanu trūkuma dēl. Piemēram, izteikts pieņēmums, ka jau pirms 1945. gada maija Skujiṇa grupas "sirdsapziņas acīmredzot bija gan dažādas laupišanas un cilvēku iebiedēšanas, gan arī dzīvības", kaut gan visi trīs brāḷi Skujiṇi un viṇu kaimiņš Ziedonis Muciņš līdz tam klusi dzīvoja Skujiņu vecāku mājās, kur darīja saimniecības darbus.

Kā Skujiņu grupas atbalstītājs nosaukts viņu kaimiņš Voldemārs Bušmanis, kuru padomju drošības iestādes aizturēja 1945. gada 5. maijā uz aizdomu pamata. 1962. gadā Latvijas PSR Prokuratūras ierosinātajā pārbaudē par V. Bušmaņa aresta apstākḷiem noskaidrots, ka NKVD un NKGB Valmieras apriņ,̧̧a nodaḷām nebija pierādījumu par viṇa saistību ar Skujiņu grupu. Tomēr čekisti pratināšanu gaitā V. Bušmanim izvirzīja safabricētas apsūdzības, kuras ar varu spieda parakstīt. Nespēdams izturēt regulāro sišanu, V. Bušmanis pēc divām nedēlāām apcietinājumā pakārās aizturēšanas kamerā (LNA-LVA, 1986-2-P-3225, 14-15, 29).

Temata sakarā nozīmīgs ir Valmieras "Liesmas" Vēstuḷu nodaḷas vadìtāja un bijušā KGB Valmieras rajona nodaḷas darbinieka Aleksandra Martinova raksts "Otrais karš”, kas publicēts 1988. gada martā. No ietverto faktu un spriedumu viedokḷa šis raksts ir visbagātīgākais, kas skaidrojams ar to, ka A. Martinovam kā bijušajam čekistam bija pieeja $K G B$ dokumentiem. 
Savā rakstā A. Martinovs visnotal, korekti vērtē partizānu cīṇu mērogus, norādot, ka partizānu kustība Valmieras apriņ,̧ī bija vājāka nekā citos reǵionos. Viṇš raksta, ka apriṇkī "uzturējās un siroja vismaz astoṇas buržuāzisko nacionālistu teroristiskās bandas", kas atbilst līdz šim brīdim apzināto aktīvo grupu skaitam. İsi raksturojot partizānu grupu darbības raksturu, A. Martinovs pauž ideologizētu viedokli, ka partizāni ir bijuši "teroristi un laupītāji, kas nostājušies padomju varas naidnieku pozīcijās un realizēja pret tautu vērstas asinainas akcijas".

A. Martinova rakstā sastopami arī fakti, kas neatbilst pieejamajos padomju drošības dienestu dokumentos esošajām ziņām un rada izdomājuma iespaidu. Piemēram, par Freimaņa grupas uzbrukumu Valmieras apriņķa komitejas trešajam sekretāram R. Zarinam un inženierim J. Osim A. Martinovs raksta, ka partizāniem bijušas sarkanarmiešu formas, taču gan abu nošauto šoferis Jānis Ķirsis, gan paši vēlāk notvertie partizāni liecināja, ka bijuši civilpersonu apgēēbā. Arī 1995. gadā izdotajās grupas vadītāja J. Freimaņa atmiṇās nav atrodamas ziņas, ka vin,a partizāniem būtu bijušas sarkanarmiešu formas (LNA-LVA, 1986-1-2023-4, 123, 138, 137; Freimanis 1995).

Rakstā "Otrais karš” var manīt arī kḷūdas čekas operatīvajā informācijā par partizāniem. Piemēram, A. Martinovs norāda, ka V. Sedlenieks vadījis savu grupu kopā ar Voldemāru Jamboru, par ko ir līdzīgas ziņas arī KGB veidotajā partizānu uzskaites kartotēkā (Martinovs 1988, 2; LNA-LVA, 1825-2-5, 867). Patiesībā V. Jamboram nebija nekāda sakara ar partizāniem. Viņš klusi dzīvoja Alojas pagasta Vilkkalnu mežā 1944.-1951. gadā pēc tam, kad bija izvairījies no iesaukšanas Sarkanajā armijā (LNA-LVA, 1986-1-4398, 67-71).

Šì kḷūida čekas materiālos ieviesās 1949. gada vasaras pirmajā pusē, kad MGB Limbažu apriņķa nodaḷas aǵents un Alojas pagasta mežstrādnieks Eduards Pogulis ar segvārdu "Ziemelis" centās izvairīties no čekas dotā uzdevuma un, balstoties uz iedzīvotāju baumām, partizānu uzbrukumus piedēvēja paša izdomātajai “Jambora bandai” (LNA-LVA, 1986-1-39741, 23-24). Materiālu pārbaudes gaitā čekisti pārliecinājās, ka Ziemelis viņiem ir melojis, taču sniegtā dezinformācija saglabājās arhīvā, un to savā rakstā izmantojis arī A. Martinovs.

\section{SECINĀJUMI}

Fakti par nacionālo partizānu cīnāām Valmieras apriṇ,̧̣ī Latvijas PSR literatūrā sāka regulāri parādīties kopš 1969. gada, līdz 80. gadu beigām gūstot aizvien plašāku atspogul,ojumu. Lai arī par apriņķa partizānu darbības vēsturi publicēts visai daudz literatūras, tajā ietvertie fakti un spriedumi bija pakārtoti okupācijas režīma ideolog̣izētajam skatījumam uz nacionālajiem 
partizāniem kā kara noziedzniekiem un vienkāršiem bandītiem, savukārt cīnās bojāgājušajiem partizānu pretiniekiem tika piešķirts varoṇa un mocekḷa tēls.

Faktu precizitāti noteica rakstu autoriem pieejamā informācija, taču tas nebija prioritāri, jo partizānu darbības aprakstiem bija jāatspoguḷo padomju propagandas redzējums, no kura atkāpes nebija iespējamas. Lielākajā daḷā gadījumu konstatējamās faktu kḷūdas rakstos ieviesušās, visticamāk, bez nolūka, taču tās varēja tikt pieḷautas arī apzināti ar mērḳi stiprināt mežabrāḷu negatīvo tēlu. Nozīmīgs elements tā veidošanā ir koncentrēšanās uz partizānu bruṇotajām akcijām, nevardarbīgo pretošanos gandrīz neminot.

Vērtējot padomju okupācijas laika literatūrā publicēto informāciju par nacionālo partizānu cīņām Valmieras apriṇkīi, jānorāda, ka tā nevar tikt izmantota kā uzticams partizānu vēstures izziñas avots, jo, pirmkārt, tā ir tendencioza un nomelnojoša, otrkārt, tajā ietvertie fakti bieži vien neatbilst patiesībai. Tāpat aplūkotajā literatūrā nav konstatējama unikāla un citos avotos neatrodama nozīmīga informācija, līdz ar ko kopumā tās zinātniskā vērtība uzskatāma par zemu.

Lai gan Valmieras apriņ,ịi pastāvējusī partizānu kustība nebija tik spēcīga kā citviet Latvijā, apskatīto nacionālo partizānu vēstures apraksti satura tendenču ziṇā neatšķiras no citiem Latvijas PSR literatūrā publicētajiem nacionālo partizānu darbības aprakstiem, kurus analizējuši mūsdienu vēsturnieki Latvijā.

\section{SAĪSINĀJUMI}

KGB - Valsts drošības komiteja (Komitet gosudarstvennoj bezopasnosti)

LNA-LVA - Latvijas Nacionālā arhīva Latvijas Valsts arhīvs

$M G B$ - Valsts drošǐbas ministrija (Ministerstvo gosudarstvennoj bezopasnosti)

NKGB - Valsts drošības tautas komisariāts (Narodnyj komissariat gosudarstvennoj bezopasnosti)

NKVD - Iekšlietu tautas komisariāts (Narodnyj komissariat vnutrennih del)

PSR - Padomju Sociālistiskā Republika

PSRS - Padomju Sociālistisko Republiku Savienība

\section{IZMANTOTIE AVOTI UN LITERATŪRA}

AVOTI

Arvīda Smilškalna krimināllieta, 1951. LNA-LVA, 1986-1-28393.

Augusta Žìgura krimināllieta, 1953. LNA-LVA, 1986-1-21843.

Edmunda Vìtola krimināllieta, 1946. LNA-LVA, 1986-1-18256.

Eduarda Poguḷa krimināllieta, 1949. LNA-LVA, 1986-1-39741.

Jāṇa Freimaṇa krimināllieta, 1948. LNA-LVA, 1986-1-2023. 
Kartotēka. Sadaḷa "Latvijas PSR VDM Valmieras apriņķa daḷas veiktās kaujas operācijas pret partizāniem". LNA-LVA, 1825-2-168.

Kartotēka. Sadaḷa "Nacionālie partizāni” LNA-LVA, 1825-2-5.

Latvijas Komunistiskās partijas Centrālā komiteja. Sevišķais sektors. Sarakste par cīnu ar bandītismu un iznīcinātāju bataljoniem, 1947. LNA-LVA, PA-101-10-75.

Kārḷa Grīnberga krimināllieta, 1945. LNA-LVA, 1986-1-17559.

Pētera Čakša krimināllieta, 1950. LNA-LVA, 1986-1-45222.

Valda Holma atmiņas, pierakstītas 2020. gadā. Autora arhīvs.

Viḷa Skujiņa krimināllieta, 1948. LNA-LVA, 1986-1-40698.

Viḷa Sedlenieka krimināllieta, 1950. LNA-LVA, 1986-1-38177.

Voldemāra Bušmaņa krimināllieta, 1945. LNA-LVA, 1986-2-P-3225.

Voldemāra Jambora krimināllieta, 1951. LNA-LVA, 1986-1-4398.

Antone, A., 1969. Atkal mājās... Liesma (Valmiera), 149, 2.

Arnava, I., 1988. Piemiņas dēstī̌̌ana. Liesma (Valmiera), 117, 2.

Baunis, P., 1978. Cīṇa, kas ilgst visu mūžu. Padomju Jaunatne, 201, 1.

Briede, V., 1980. Vinu sirdis liktas pamatos. Progress (Limbaži), 80, 2.

Jansons, F., 1977. Lai salapotu dzīvības koks... Progress (Limbaži), 108, 2.

Līdace, A., 1988. Vēstures priekšā būsim godīgi. Cīna, 191, 2.

Martinovs, A., 1985. Skarbā īstenība. Liesma (Valmiera), 121, 2.

Martinovs, A., 1988. Izsakām savu viedokli, Liesma (Valmiera), 59, 2.

Martinovs, A., 1988. Otrais karš. (1. daḷa) Liesma (Valmiera), 42, 2.

Martinovs, A., 1988. Otrais karš. (2. daḷa) Liesma (Valmiera), 43, 2.

Martinovs, A., 1988. Otrais karš. (3. daḷa) Liesma (Valmiera), 45, 2.

Martinovs, A. (sast.), 1985. Upuri apsūdz. Publikāciju krājums, 1985. Valmieras muzeja krājums.

Melnūdre, D., 1980. Pāles stingrie pamati. Progress (Limbaži), 84, 2.

Rēpele, M., 1985. Ielūkojoties milicijas vēstures lapaspusēs. (2. daḷa) Darba Karogs (Valka), 62, 2.

Rēpele, M., 1985. Ielūkojoties milicijas vēstures lapaspusēs. (3. daḷa) Darba Karogs (Valka), 63, 2.

Riekstinšs, J., 1980. Partorga taka. Zvaigzne, 16, 5.

Riekstinšs, J., 1984. Lai tēva gājums turpinātos. Cīna, 19, 2.

Riekstiņš, J., 1986. Ziemel̦vidzemes mežos. Cīna, 272, 2.

Skuja, Z., 1970. Trag̣ēdija pirms rītausmas. Progress (Limbaži), 17, 2.

Smirnova, A. 1969. Pirmās revolūcijas liesmas. Progress (Limbaži), 45, 2.

Taimiņa, I., 1980. Atgriešanās - ilgi gaidīta un grūta. Progress (Limbaži), 50, 1.

Taimiņa, I., 1985. Ik miera pavasaris jāaizstāv. (1. daḷa) Progress (Limbaži), 36, 2.

Taimiņa, I., 1985. Ik miera pavasaris jāaizstāv. (2. daḷa) Progress (Limbaži), 37, 2.

Taimiņa, I., 1985. Ik miera pavasaris jāaizstāv. (3. daḷa) Progress (Limbaži), 38, 2.

\section{LITERATŪRA}

Freimanis, J., 1995. Ar naidu sirdī. Rīga: Pētergailis.

Ločmele, K., Procevska, O., Zelče, V., 2011. Svētki, atceres dienas un to rituāli Krievijā: 
padomju pieredze, tās transformācija un šodiena. Uzvaras svētki Krievijā un Latvijā. Latvijas sociālā atmiņa un identitāte. Manuskripti. 3. laidiens. Rīga: Valsts pētījumu programma "Nacionālā identitāte".

Ratnieks, R., 2018. Nacionālo partizānu grupu veidošanās un darbība Ziemeḷietumvidzemē 1944. gada rudenī-1945. gadā. Latvijas Universitātes Žurnāls. Vēsture, 5, 67.-80.

Ratnieks, R., 2019. Nacionālo partizānu grupu darbība un sagrāve Ziemeḷrietumvidzemē (1944-1953). Jauno vēsturnieku zinātniskie lasijumi, IV, 125.-137.

Sārnis, J., 2015. Pieviltie. Cesvaine: Dardedze.

Strods, H., 1996. Nacionālo partizānu karš: 1944-1956. Rīga: Preses nams.

Strods, H. (sast.), 1999. Nacionālo partizānu karš: 1944-1956. Dokumenti un materiāli. Rīga: Preses nams.

Turčinskis, Z., 2017. KGB slepenie arhīvi. Spiegu spēles Latvijā: metodes, pan̄ēmieni un personas. Pieejams: https://www.lsm.lv/raksts/dzive--stils/vesture/kgbslepenie-arhivi.-spiegu-speles-latvija-metodes-panemieni-un-personas.a259750/ [Skatīts 12.12.2020.]

Turčinskis, Z., 2017. Bruṇotā pretošanās padomju un nacistiskajai okupācijai (19401957). Nepārtrauktibas doktrīna Latvijas vēstures kontekstā. T. Jundzis (zin. vad.). Rīga: Latvijas Zinātñu akadēmijas Baltijas stratēǵisko pētijumu centrs, 105.-123.

Turčinskis, Z., 2011. Ziemel̦vidzemes mežabrāḷi. Latvijas nacionālo partizānu cinnas Valkas

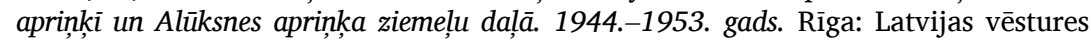
institūta apgāds.

\section{ATSAUCES UN PIEZİMES}

${ }^{1}$ Vienīgās publikācijas līdz šim ir šĩ raksta autora divi zinātniskie raksti "Nacionālo partizānu grupu veidošanās un darbība Ziemel̦rietumvidzemē 1944. gada rudenī 1945. gadā" un "Nacionālo partizānu grupu darbība un sagrāve Ziemeḷrietumvidzemēē (1944-1953)", kuri norādīti izmantotās literatūras sarakstā.

${ }^{2}$ Latvijas Universitātes Vēstures un filozofijas fakultātē izstrādē esošais promocijas darbs "Nacionālo partizānu darbība Rietumvidzemē (1944-1953)".

${ }^{3}$ Pēc raksta autora aprēkiniem.

${ }^{4}$ PSRS drošības dienesta Viskrievijas Ārkārtas komisijas (VĀK) apzīmējums, kas radies no tās saīsinājuma krievu valodā un vēlāk piemērots VĀK pēctečiem. Faktiski tas tika oficiāli izmantots čekas lietvedībā.

${ }^{5}$ No dažiem ievērojamākajiem piemēriem 1945. gadā var minēt aptuveni 50 vīru liela partizānu grupējuma uzbrukumu Abrenes aprinḳa Tilžas pagasta centram 4.-5. jūlijā, 40-45 partizānu lielas grupas uzbrukums Gaujienas ciemam 14. septembrī, kā arī 20 vīru lielas partizānu grupas uzbrukumu Kabiles pagasta centram 24. decembrī.

${ }^{6}$ Piemēram, Annas Sakses romāns "Pret kalnu" (1948), Viḷa Lāča romāns "Uz jauno krastu" (1952).

${ }^{7}$ Nozīmīgākā un, iespējams, zinātniskākā J. Dzintara publikācija par Latvijas nacionālajiem partizāniem ir zinātniskā izdevuma "Latvijas PSR Zinātnuu Akadēmijas Vēstis" 1982. gada 10. numurā publicētais raksts "Latviešu fašistiskā buržuāzija hitleriešu izlūkdienesta kalpībā".

${ }^{8}$ Istrebiḳel̦i (istrebiteli) - PSRS drošības iestādēm pakḷauto paramilitāro palīgvienību kaujinieki, kuru uzdevumi bija režīma represīvo funkciju nodrošināšana, objektu apsardze un brunotās pretestības apkarošana. Nereti zinātniskajā literatūrā tiek izmantots latviskotais termins "iznīcinātāji".

${ }^{9}$ Pēc Latvijas statistikas atlasa (1938) datiem, 1935. gadā 96,95 \% apriṇḳa iedzīvotāju bija latvieši. 


\title{
NATIONAL PARTISAN STRUGGLES \\ IN VALMIERA DISTRICT (1944-1953): REPRESENTATION IN LITERATURE OF THE LATVIAN SSR
}

\author{
REINIS RATNIEKS \\ MA in History, Ph. D. student at University of Latvia \\ E-mail: ratnieksr@gmail.com
}

\begin{abstract}
The article discusses the representation of the partisan struggles in Valmiera district in the literature of the Latvian SSR. The publications released during the Soviet occupation provide large amount of information on the armed resistance in the region but aspects of its history were interpreted in accordance with the Soviet propaganda and are therefore biased, defamatory and contain many false facts. Descriptions of partisan activity emphasized the cases where Soviet occupation functionaries and activists were killed by partisans to give the impression that the armed resistance movement was brutal and criminal in nature. At the same time, nonviolent methods of resistance used by partisans were rarely mentioned in the Soviet literature.
\end{abstract}

Keywords: National partisans, resistance movement, Soviet occupation, literature, Valmiera district.

\section{SUMMARY}

The article discusses the representation of the national partisan struggles that took place in Valmiera district in the literature of the Latvian SSR. The facts of these events were published in the press of the Latvian SSR only from the end of the 1960s, when the celebration of the Victory Day was reinvigorated at the national level in the Soviet Union. Publications dedicated to the event also provided minimal coverage of the post-war situation, including some facts about national partisan struggles. In the 1980s, as a part of a new Soviet propaganda campaign, articles were published in the newspapers of Latvian SSR that focused entirely on national partisan struggles in Valmiera district and introduced a lot of new information to the public domain.

The publications on history of national partisan struggles in the Valmiera district were written from the of perspective of the Soviet propaganda. The partisan movement was analysed and portrayed through the discourse 
of political banditry, in which partisans were given the role of political criminals, while the Soviet authorities, their functionaries and activists were positioned as heroes and martyrs in partisan attacks. Soviet literature strongly emphasized violent actions by partisans, but did not mention nonviolent resistance acts, such as hoisting the flag of the Republic of Latvia and putting anti-Soviet leaflets in public places. Most likely, the inclusion of such facts would conflict with the occupation regime's efforts to portray national partisans as a part of a brutal resistance movement that was based on questionable ideals. Many false facts about the national partisan struggles in the Valmiera district can also be found in the works of the Soviet authors.

As the representation of the partisan movement in the Soviet literature is distorted in terms of both facts and assessments, it cannot in itself be used as reliable source to study the aspects of the national partisan struggles and their causes. In comparison with other sources Soviet literature does not contain any significant unique facts, therefore, its scientific value is low. 


\title{
AGREEMENT ON THE MATTERS OF RELIGION CONCLUDED DURING THE ASSEMBLY OF TERRITORIAL ESTATES IN PERNAU (1552) IN CONTEXT OF THE DISPUTE OF RIGA (1549-1554)
}

\author{
MARGARITA NOVIKOVA \\ Mg. hist. \\ E-mail:margarita.novikova@inbox.Iv
}

\begin{abstract}
The article focuses on the history of the agreement text produced during the assembly of Livonian estates in Pernau in 1552, its background and connections to the dispute of Riga (1549-1554). Results indicate that the agreement was concluded between Livonian cathedral chapters and nobilities. The agreement concerning the religion was phrased under the influence of the representatives of the territorial estates of the archbishopric of Riga; its interpretation depends on the understanding of the extended "council phrase", because the cathedral chapter of Riga used it to achieve broader opportunities in their attempts to regain the secularized property.
\end{abstract}

Keywords: Reformation, Livonia, diets, dispute of Riga, assembly of territorial estates in Pernau in 1552, freedom of faith, cathedral chapter of Riga.

\section{INTRODUCTION}

The impact of the Reformation on the history of Livonia is well established in historiography. Two events are often mentioned in respect to the spread of Reformation across Livonia. The assembly of the ambassadors of the Livonian territorial estates in Pernau (present-day Pärnu in Estonia) in 1552 and the Livonian Diet in Wolmar (present-day Valmiera in Latvia) in 1554. These are thought to have univocally decided on a religious freedom for all of Livonia. Both sources are well known since the $18^{\text {th }}$ century. 
Both are important to the historiographical narrative, as they mark great advancement of the Reformation and underline the contrast that should have existed between the widespread new faith and the old ecclesiastical political system just before its dissolution during the Livonian War (15581583) (Arndt 1753, 217; Brachmann 1850, 197-198; Richter, A. v. 1857, 304-305; Müller 2014, 323-327; Arbusow, 1918, 820-822; although not: Pistohlkors 1994, 156-157). Interestingly, both of these events (the texts that inform us thereof and the contexts that surrounded their production), along with the religious situation in Livonia in the early 1550s have not been studied in detail yet, making it one of the recognized blind spots (see: Juhan Kreem (2014b, 183)). Additional research is motivated by the fact that newer studies of the religious situation in 1540s partially contradict the aforementioned narrative by demonstrating that religious reforms depended on the political situation rather than personal beliefs (Maasing 2019, 269-272; Kreem 2019, 458-462; Lange 2014, 146-156; Hartmann 2004, 276-277; Müller 2014, 298).

The aim of this paper is to analyse the agreement concerning the religion that was produced at the assembly of territorial estates in Pernau in 1552 (hereafter - agreement of 1552) within the contemporary political context, more precisely, in connection with the dispute of Riga. The paper reviews the circumstances of production, issuers and authors, determines the political context and pragmatic aspects of the way the agreement was phrased. The results are obtained through text analysis and comparative analysis of the agreement and related sources, historically-genetic synthesis of the way the relevant phrases were altered, and interpretation of the pragmatic meaning of the phrases and their change in context of the politics advanced by their possible authors. ${ }^{1}$

\section{THE AGREEMENT OF 1552: PREHISTORY, SOURCES AND AUTHORS}

In early 1552, as the negotiations with Tsar Ivan the Terrible (Иван IV Васильевич Грозный, years in office: 1533-1583) about a prolongation of peace treaty with Muscovy that had to end in September 1552, were not moving forward, the landlords, primarily Master of the Livonian Order Heinrich von Galen (years in office: 1551-1557) had raised a question of military tax in order to prepare for defense (Hartmann (1551-1557), No. 1556, No. 1556/1, 1554). Since the nobility of the lands of the Order proclaimed it to be a matter that concerned other territorial estates, the Master had to ask other Livonian landlords Archbishop of Riga Wilhelm von Brandenburg (years in office: 1530-1540 as coadjutor, 1540-1564), Bishop of 
Curonia and Administrator of Samland-Wiek Johannes von Münchhausen (years in office: 1540-1560 and 1542-1560), and Bishop of Dorpat Herman von Wesel (years in office: 1552-1560) to send representatives of their respective cathedral chapters, nobility and towns, whose privileges granted them freedom from taxes, to discuss the question together during a separate assembly (Hartmann (1551-1557), No. 1554, 1554/3, 1559). On 10 July 1552, the ambassadors of all territorial estates including those from the towns of Riga, Reval (present-day Tallinn in Estonia) and Dorpat (present-day Tartu in Estonia) convened in Pernau. The final agreement stated: everyone should stay by the same religion and pastoral care until the decision of a church council or a univocal agreement, the estates also refused to agree to a tax, or fund a school, instead they promised to participate in the defense of the land according to their traditional duties, decided to postpone an answer regarding the recruitment of mercenaries, proposed a draft of a regulatory ordinance (Polizeiordnung), agreed on the matter of runaway peasants and trade in towns (Hartmann (1551-1557), No. 1565, NNM, 7./8. Bd., 341-342). These decisions were presented to the landlords (Hartmann (1551-1557) No. 1565; Brevern 1842, 157-159) later that year. They themselves reviewed the questions during the following Livonian diet, which gathered in Wolmar only in January of 1554. As considered in the historiography, they approved the decision of the estates on the matters of religion (Richter, A. v. 1857, 304-305; Brachmann 1850, 197-198). It is not clear what motivated a discussion and a decision on the topic of religion in 1552 in the first place? Although the religious question was traditionally placed as the first in both agreement texts, in 1552 it appears to have been just an addition to the main problem of military tax; the surprised reaction of the Archbishop of Riga Wilhelm von Brandenburg also shows that this topic was not a part of the initial agenda (Hartmann (1551-1557) No. 1565). Although this and some other additional questions were probably discussed just because an opportunity for an assembly had occurred, this does not revoke the question about the motivation and the goals behind the discussions and the agreement on the matters of religion (hereafter - the agreement).

Historiography usually reviews both agreements (1552 and 1554) as connected and attributes them to the grade of the Lutheranisation of Livonia and the situation in the Holy Roman Empire, i.e., the Treaty of Passau (2 August 1552). For example, Wilhelm Brachmann saw the decision of 1552 as the expression of the common standpoint of Lutheranised estates that was made possible by the fact that they had convened separately from the landlords, which is to general and only serves to prove the known tendency for Lutheranisation rather than explain the agreement itself (Müller 2014, 322327; Richter 1857, 304-305; Brachmann 1850, 198; Arbusow 1918, 820-822). 
The treaty of Passau is mostly seen as the event that allowed the landlords to make the decision in 1554. It had ended the Prince's Revolt (Fürstenaufstand, 1552) - a war started by an alliance of imperial princes (one of whom was a brother of archbishop Wilhelm - Albert of Prussia (Albrecht von Preussen, years in office: 1510-1525 as the last Master of the Teutonic Order in Prussia, 1525-1568)), as a reaction to the emperor's politics, the most important part of it being the publication of the Augsburg Interim (1548) - a religious law that imposed certain, mostly unacceptable, religious norms on the Protestants. The history of the decision regarding the religion that was concluded in Passau, started in April 1552, after the factual victory of the princes, with the so-called Program script (Programmschrift) of their leader Maurice Prince Elector of Saxony (Moritz Kurfürst von Sachsen, years in offices: 1541-1547 as duke, 1547-1553 as Prince Elector). It demanded confessional inviolability and everlasting peace for the Protestant estates. This demand was partly fulfilled in the preliminary agreements (Passauer Abrede) met by the deputies of both opposing parties, they had agreed that the peace should last until a univocal agreement. Then in July during the negotiations with the emperor Charles $\mathrm{V}$ (Karl V, years in office: 1519-1556) himself this decision was partly affirmed as he only agreed to grant these freedoms until the next imperial diet (Drecol 2000, 10-57). The information about the prince's demands could have been publicly known since the spring, but to conclude whether in fact the Livonian agreement was inspired by the imperial public discourse surrounding the Prince's Revolt and the demands of the victorious side, one would have to know more about the scope of information that was available in Livonia before July 10. Wilhelm's of Brandenburg correspondence shows that he regularly received newspapers from the Holy Roman Empire and the position of the emperor was known in Livonia in May. It also attests that he was not supportive of the emperor (Hartmann (1551-1557) No. 1561), but upon receiving an invitation to the Council of Trent in October, his intentions were to behave as a complacent prince of the empire (Hartmann (1551-1557) No. 1565). The Order hesitated to react to the news about the complicated situation of the emperor in May of 1552. This indicates that even though the emperor suffered a defeat and the situation had changed in comparison to 1548-1549, at least the landlords were careful in their actions. Additionally, this was exactly what Albert of Prussia had advised his brother to do (Hartmann (1551-1557), No. 1565, 1554, 1558, 1559, 1526).

Thus, the events in the empire could have created favourable circumstances for the later decision of 1554, and might have inspired the decision made in 1552 (as hypothesised by Thomas Lange (2013, 174-175)), but the connection remains unclear. Even if the events in the empire had 
inspired the decision, this does not explain the goal behind the Livonian decision of 1552 - one would have to know whether the territorial estates just repeated the discourse in the empire or not, and why?

These questions are especially intriguing, because the Augsburg Interim that was cancelled by the Treaty of Passau (it was one of its goals) had been received with mixed reaction by the Livonian landlords and territorial estates in 1548 when it was first published. The towns were against it. A part of the Order was against it, as well. The Order in general was torn between the political need to refrain from sabotaging the relationship with the Holy Roman Emperor, simultaneously preserving good relationship with the Lutheran towns, a great deal of its brethren were Protestant and personally were opposed to it. The archbishop was personally torn between his wish and need to defend the Protestants, his ecclesiastical position, as well as the need to uphold the relationship with the emperor and to use the Interim for his political goals. Meanwhile, the reaction of the bishops, other cathedral chapters and nobilities is mostly unknown, for example, the bishop of Curonia and Samland-Wiek tried to introduce the Interim but failed, the cathedral chapter of Riga also expressed positive opinions about this imperial law (Kreem 2014a, 136-139, Müller 2014, 314-317). In 1552 the political situation in the empire might have provided an opportunity for the Master or the archbishop to solve both problems - to act in accordance with the emperor's politics and in friendship with Lutheran towns and also according to their beliefs, however, the same was not certain in respect to the cathedral chapters and possibly even the territorial nobilities, whose religious position at the time Kreem evaluates as ambivalent (Kreem 2019, 458).

The position of clerics and nobles proves to be especially relevant after a detailed review of the agreement document itself. The first and the only edition of the agreement of 1552 was published in 1794 from a contemporary transcript in a manuscript that belonged to an advisor of the archbishop and the standard-bearer of the archbishopric Heinrich von Tiesenhausen (approx. 1520-1600) and lacked the ending starting with the clause of corroboration (stating the means of authentication, i.e., that there are signatures and seals attached) of the context (the main middle part of the document's text) and including the whole eschatocol (the final closing part of the document's text containing the names of signing parties and the dates) (NNM, 7./8. Bd., 341-342). Thus, nothing caused doubt regarding the plausibility of the intitulation clause (the stating of the producers), where the agreement was attributed to all of the estates, towns and communities. Despite the fact that the ending was published in 1842 by Georg von Brevern (1842, 157-159) and showed that the representatives of the towns were not mentioned in the subscription clause (stating the signing parties), 
unfortunately, it did not find much recognition in the following historical works (Brevern 1842, 157-159; Arbusow 1918, 820-822). Of course, the lack of subscription on its own might not have compromised the traditional interpretation, after all, it was stated that the representatives were signing and sealing "gemeyne diesser Lande wegenn". ${ }^{2}$ However, the fact that the text contained articles, which disagreed with the general politics of the three major Livonian towns (returning of escaped peasants, etc.), as well as the strained relationship between the towns and the rest of the estates caused by those same disagreements suggests otherwise (NNM, 7/8 Bd., 341-342; Brevern 1842, 157-159; Niitemaa 1949, 287-289). Namely, the decision made during the assembly was an agreement between the ambassadors of the cathedral chapters and the territorial nobilities.

Thus, the religious peace of 1552 was put forward not only by confessionally heterogenous territorial nobilities, but also by the clerics who had favoured old faith and a part of whom had welcomed the Augsburg Interim in 1548-1549. On the contrary, the offer was insufficient to acquire the approval of the Lutheran towns.

Further new details about the production of the agreement, and especially the part concerning the matters of religion, can be gained from an undated document presented by archbishopric representatives during a "Landesverschreibung" - an "assembly of the land". It was published in the $5^{\text {th }}$ volume of Monumenta Livoniae antiqua and dated to approximately 1555, but needs to be attributed to the assembly of 1552 . This has been first proposed by Wilhelm Brachmann $(1850,198)$ and is supported by the fact that the proposition is thematically and structurally identical, but less developed than the final agreement of 1552, while many phrases, as well as all of the decisions are the same (including their rejection of a military tax), which is a sign of genetic connection (MLA, Bd. 5, No. 266; NNM, 7/8 Bd., 341-342; Richter, A. v. 1857, 304-305).

Although more sources are needed to draw a definitive picture, this proposition of the archbishopric's cathedral chapter and nobility, i.e., their ambassadors, was likely the textual source of the final agreement about the religion. Firstly, the protocol (introductory part of a document) of the final agreement states that the estates of the archbishopric had initiated the assembly. It might not be entirely true, as mentioned above the matter had arisen during the discussions in the Order and the question of religion might have been connected to the inner politics of the Order as well, although as we know, it was not a part of the initial agenda (NNM, 7/8 Bd., 341-342; Hartmann (1551-1557), No. 1565, see above). However, it might not be that important, whether the archbishopric estates initiated the discussion at all, because, secondly, the estates of the archbishopric (following the status of the archbishops themselves) aspired to and demanded to be considered 
the "eldest in the land", thus they were mentioned first in the documents and had the $1^{\text {st }}$ session in the negotiations, so this proposition could have been read first and they might have had more weight behind them during the actual discussions (NNM, 7/8 Bd., 341-342). This is important to note, because, thirdly, the part of their proposition that concerns the religion is almost identical to the final agreement and it can be concluded that the final agreement was not only phrased by the Livonian cathedral chapters and nobilities many of whom welcomed the Interim, but it happened under the influence of the cathedral chapter and the nobility of the archbishopric of Riga, of whom the chapter definitely had welcomed the Interim, and also was involved in a long lasting dispute over secularized ecclesiastical property in Riga, which made them not only theologically, but politically engaged with the religious question (Müller 2014, 308-322).

Hence, religious freedom until a decision by a church council or another univocal agreement was proposed by not at all confessionally indifferent representatives of the estates of the archbishopric who were institutionally interested to regain their secularized property in Riga.

\section{POLITICS OF THE CATHEDRAL CHAPTER OF RIGA DURING THE DISPUTE OVER SECULARIZED PROPERTY IN RIGA (1549-1551)}

The long-lasting dispute between the archbishop of Riga, the cathedral chapter of Riga and the town of Riga had started in 1526 as a consequence of Reformation. In the years to come it determined much of the archbishop's politics, the politics of the cathedral chapter as well as their relationship. During the negotiations, both sides, which had exactly the opposite demands, were always confronted with the need to surrender a part of them. The archbishop and the cathedral chapter had to compromise between the need to regain the property and income and to restore the old ecclesiastical order and power relations in the town. For example, in 1542 in the Agreement of Lemsal (present-day Limbaži in Latvia) the archbishop had to agree to sacrifice his ecclesiastical jurisdiction until a decision by a general or national church council in order to receive a promise that the town would return under archbishop's half-rule. The importance of the dispute has been reviewed in depth (see, for example: Müller 2014, 251-166, 308-322; Lange 2013, 151-157, 164-166), only the last episodes in 1549-1554 will be analysed for the purpose of this article.

The dispute had been renewed in 1549. The Archbishop Wilhelm von Brandenburg (and his advisors) could turn around Emperor's accusations of having supported the Union of Schmalkalden which he had received 
in November 1548 simultaneously with the order to enforce the Interim. He used this situation to renew the old dispute over the ecclesiastical property and jurisdiction in the town (Müller 2014, 312-317; Hartmann (1540-1551), No. 1459/2, No. 1468/3). This was possible, because Riga had been a member of the Union and was already facing retribution (Müller 2014, 315-317, Hartmann (1540-1551), No. 1468, No. 1468/3, No. 1468/4). During the summer of 1549 , the dispute was reviewed in the Aulic Council (Reichshofrat). (Müller 2014, 318-322; Hartmann (15401551), No. 1510). At the time the town was threatened by the emperor's order to introduce the Interim (1548) and possible fees (MLA Bd. 4., 47-59) for its support of the Union of Schmalkalden, thus, it was of no surprise that, contrary to the situation in the 1530s and 1540s, the town's ambassadors proposed a compromise - they were ready to bargain for Riga's religious freedom by returning a bulk of the property, but demanded from the archbishop to issue a written confirmation of their religious freedom. In general, the standpoints of both sides were still too antagonistic and the negotiations ultimately were unproductive (Müller 2014, 312-317; Hartmann (1540-1551), No. 1483). Afterwards, the emperor (i.e., the Aulic Council) appointed a commission of three arbitrary judges to review the dispute back in Livonia. These were: Master of the Order Johann von der Recke (years in office: 1542-1549 as coadjutor, 1549-1551), Bishop of Curonia (and Administrator of Samland-Wiek) and Bishop of Dorpat, Jodokus von der Recke (years in office: 1543-1551/1553). They had to solve the dispute or return it to the Aulic Council (Müller 2014, 318-322; Hartmann (1540-1551), No. 1510).

Local negotiations began on 9 February 1551 in Wolmar, following a Livonian diet, that was devoted to the peace treaty with Muscovy (Hartmann (1540-1551), No. $1506 / 1$, No. 1514, No. 1514/1). As before, the negotiations were unproductive. As the archbishop would later write to his brother, to avoid complete failure the arbitrators proposed an agreement project and the archbishop and the cathedral chapter decided to accept it (Müller 2014, 318-322; Hartmann (1540-1551), No. 1517). Its text was largely based on previously mentioned compromise propositions, the town was granted freedom to further use the cathedral for Lutheran sermons (Compare Hartmann (1540-1551), No. $1483 / 1$ and No. $1483 / 2$ to No. 1517/2). However, the text also briefly touched upon the subject of religious reform and church council. This part of the text warrants more attention, as its phrasing differed from the previous agreements concluded during the Livonian diets, as well as agreements regarding the dispute of Riga (in the 1540s). Previously, a demand for any or part of the change to be postponed until the free general or national church council had been a part of every agreement project - this phrase became a norm in Livonia, 
as it had happened in the empire - it allowed to postpone the decision and to move forward with other negotiations. Furthermore, in Livonia this proved to be especially useful for town's politics (Kreem 2014b, 188, 263; MLA, Bd. 5, No. 257). However, in this agreement project, the authors rephrased the sentence by adding a proposition that the final decision on the religious reform could not only be postponed until a decision by a free general or a national (imperial) church council, but also until a univocal decision made by the local landlords, estates and towns to accept and introduce a change in religion: "[...] Dajegen kan vnd will der herr Ertzbischof vndd Capittel geduld vnd leiden, die Jtzige angenhomene Religion *sampt den Cristlichen Ceremonien*3 Jn der Thumb Kirchen Zu pflegenn, So lang ein frei Christlich generall oder National Concilium, daruber, oder aber semptliche gemeine herrn Stande vnnd stedte der lande zu liefland Jm der Religion Enderung *dem Wordt gottes nicht zu wider* vornhemen vnd bewilligen." ${ }^{4}$ Moreover, the ambassadors of Riga were requested to promise their approval in advance in a reversal document (Regest - Hartmann (1540-1551), No. 1517/2, original GStA PK, XX HA, HBA D, No. 1517, Bl. 9v). Hence the decision about the reform, as well as the freedom granted to the towns would not just be postponed until a decision by a free general church council (i.e., the Lutherans could decide to accept it as such), but also until a local decision. Although other causes might have determined such alterations, it is important to note that they were beneficial for the "old faith" and the cathedral chapter and precarious for the Lutheran town, because a local decision was more probable and would more likely benefit the landlords.

An attempt to extend the council phrase was unsuccessful - it was unacceptable to Riga. After Johann von der Recke died in May of 1551, Riga negotiated a new guarantee of religious freedom in the town from his successor Heinrich von Galen, who had agreed to confirm all the privileges that had been granted by his predecessors and demonstrated his benevolence by attending a Lutheran sermon during the following ritual introduction into the town on 26 September. The town council, however, was expected to fulfil its part of the bargain (MLA, Bd. 4, 54; Hartmann (1551-1557), No. 1536, 1540/1). In December of 1551, an intermediary agreement was concluded on the basis of the aforementioned compromise propositions the cathedral chapter and the archbishop regained important parts of their previous possessions, the town - its freedom of religion until a free general church council. The decision was to be sent to the Aulic Council. The ensuing questions had to be discussed during court sessions led by the lords of the town - the Master of the Order and the Archbishop of Riga, the dispute remained partially unresolved (Müller 2014, 320-321; Hartmann (1551-1557), No. 1542). 
For the purpose of this article it is most important to note that the cathedral chapter continued to attempt and use an extended variant of the phrase. Another court session took place in September 1554 - at the end of these negotiations, the chapter tried to introduce a phrase similar to the one used in 1551 into the text of the new agreement. Rigans wished to postpone any further sessions until the church council. The disagreement could not be overcome and was so important that this caused a complete failure of otherwise promising negotiations; the dispute was to be sent to the Imperial Chamber Court (Reichskammergericht). As an Elder of the Great Guild of Riga, Reinhold Germann explained it the Book of Elders: "[...] de sullden stan tho Eyneme kristlycken ghene ralle [General - C. N.] Conssyllyum. Dar hebben de kappyttells heren samtt alle Ereme anhanghe nychtt an wyllen, sunder ydt sullde stan tho Eynneme Eynhellyghen ffryuyllyghen wor ghellykynghe [Vergleich - C. N.]"5 (MLA, Bd. 4, 87). His own note in a draft is more precise, it shows that the whole controversy started after the town that had agreed to a compromise, had asked that no further sessions would be held until the church council (LNA-LVVA, 214-6-100, 140-141). Hence, trying to introduce a wider meaning into the agreement or postponing the dispute until a session in the Imperial Chamber Court was more acceptable than settling with a compromise, but simultaneously agreeing to postpone any new sessions (and possible gains) until a (possibly indefinite) decision of a church council.

Thus, the ambitions of the cathedral chapter had not decreased since the 1530s, it tried to regain its possessions and authority completely (with the support of the ambassadors of the nobility). However, the methods changed, and the canons were ready to accept the religious freedom in the town as an intermediary situation. During the dispute the chapter repeatedly tried to phrase the agreement in a way that ensured the possibility of further negotiations and a local decision. The town's representatives were aware of this risk, refused to accept it and attempted to omit any further negotiations. The results of the court session in December of 1551 point to the fact that the cathedral chapter did not achieve its goals and was interested in further negotiations.

\section{THE MEANING OF THE AGREEMENT OF 1552 IN THE CONTEXT OF THE DISPUTE OF RIGA}

Aforementioned episodes from the history of the dispute and the attention that was given to seemingly minor changes in the phrasing of these agreements, finally turn the researcher's attention back to the assembly of 1552, as both the proposition of the archbishopric estates and the final 
agreement contained extended variants of the phrase about the church council. The proposition of the archbishopric estates repeats the agreement project of February 1551, but the final agreement contains the same phrase that would later be employed by the cathedral chapter in September of 1554. In 1551, the text stated that "oder aber semptliche gemeine herrn Stande vnnd stedte der lande zu liefland Jm der Religion Enderung *dem Wordt gottes nicht zu wider* vornhemen vnd bewilligen" (GStA PK, XX HA, HBA D, No. 1517, Bl. 9v). The proposition of 1552 stated that "[...] so viel die religion vnd gotlichs wordt belanget, sich diesser lande bewilligung nach (das ein Jder her, Standt vnd Stadt, bis vf ein frei christlich Concilium vnd einhellige bewilligung vnturbirt vnd vnangefochten gelassen werden soll) gemes halten [...]"7 (MLA, Bd. 5, No. 266; Richter, A. v. 1857, 304-305). The final agreement of 1552 was different: "[...] so viell die Religion vnd gottiges Worth belanget, das ein jeder hohes vnd niedrigen Standes, jn vnd bej demselbigen, vermuge affgerichteter Recesse, biß auff ein algemein cristlich Generall Concilium oder einhellige Vergleichung vnangefochten vnd vnturbirett gelaßen werden ßoll"8 (NNM, 7/8 Bd., 341-342). Lastly, in September 1554, the text stated that "[...] ydt sullde stan tho Eynneme Eynhellyghen ffryuyllyghen wor ghellykynghe" (MLA, Bd. 4, 87). Thus, during the production of the final agreement in 1552, the phrase was used and changed, probably, with the same goal that determined its use in 1554.

The fact that both extended variants of the phrase about the church council that were used in 1551 and 1554 were perceived as synonymousby the involved contemporaries (in spite of alterations) is supported by a statement that Rigan ambassadors made to the representatives of Reval and Dorpat during another assembly in February 1555. They explained, to anticipate any "ill-intentioned gossip", especially addressing those who had not been present during the court session in Wolmar in 1551, that the failure of the session in September of 1554 was caused by the fact that then, as in 1551, the cathedral chapter had tried to insert an unacceptable phrase into the agreement: "[...] das etliche art[ikel] $d$ [er] Religio[n] anhengig bis zu einhellig[en] vergleichung der hern stende vnd stet diesser lande stehen solt."). ${ }^{10}$ Although other ambassadors did not show any special interest in this account (TLA, 230-1-Br 14, p. 491. r.-493. r.), this also demonstrates that the Rigans perceived the neutral appearance of the phrase and felt the need to explain the connection to previous events in order to prevent false accusations.

The reason for altering the variant of 1551 might have been the reaction it had caused. In 1551 the agreement was met with more or less sharp negative reactions and the extended "council phrase" was at the heart of this criticism. While the Town Council called the topic of reform irrelevant to the negotiations on the property and jurisdiction, and asked to exclude 
it entirely, the more radical author directly connected this extended phrase and the possibility of a local decision to the threat of Augsburg Interim being imposed on the towns against their will. A pamphlet by a known supporter of Protestant cause, Johannes Lohmüller (approx. 1483-1560) criticized the agreement and damned its authors and the archbishop calling them "papists" and "interimists" (Müller 2014, 318-322; Hartmann (15401551), No. 1517/3). An entry made by an Elder of the Great Guild Laurentz Zimmermann, in the Book of Elders of the Great Guild of Riga explicitly brings forward such suspicions - here he cites the passage of the agreement that caused the controversy before giving his explanation: "[...] dat de stadt solde En reüertzal [Reversal - C. N.] geüen, darin vorwilgen offt vor schriüen, so de hern düsser lande hir im lande Ene vor andringe Im lande indem tzarmonien vnde gades Densten worden anrichten (wente se heddent Inttrim angenamen), dat wi vns dar In der stadt ock wolden ghelick metick [gleichmässig C. N.] na holden."11 (MLA, Bd. 4, 57]). This entry was made at the end of 1551 (MLA, Bd. 4, 60) and probably was connected to the polemics started by Lohmüller, however it shows that the phrase was the cause (or a pretext) for concern, because it attempted to change a normative traditional "council phrase" that had allowed to leave the religious question in the competence of higher authority instead of a local one.

This reaction seems to be rather polemical in nature. The original phrasing appears to have been rather neutral; the text also did not specify what kind of decision would be made. Additionally, an insert on the margin in a draft sent by the archbishop to his brother, Duke of Prussia, suggests that the Reform was supposed to be in accordance with the Evangelium ("[...] Im der Religion Enderung *dem Wordt gottes nicht zu wider* vornhemen."), ${ }^{13}$ which would make the neutral phrase used in the text itself sound more acceptable to the Lutherans and less vague and threatening (Jörgensen 2014, 63; GStA PK, XX HA, HBA D, No. 1517, Bl. 9v), however, the town might not have received a document that contained these notes. While the analysis of the actual motives of the authors in 1551 exceeds the scope of this article, it is important to note that in 1551 the Augsburg Interim was still sufficiently present in the local discourse, it allowed to discredit the agreement in the town and associate strong negative connotations to the text. It was those connotations that the estates of the archbishopric must have tried to overcome in 1552 and 1554 to persuade the towns, i.e., primarily Riga, to join the final agreement, thereby agreeing that the freedom of religion and other changes were only granted until some kind of univocal decision, including a local one. It was those connotations and the actual meaning that could later be employed for the benefit of its authors, which motivated Riga to refuse.

Although in 1551, as in 1554, the phrase was used unsuccessfully, it is hard to judge whether it was the single cause behind the refusal of towns 
to join the agreement of 1552. For example, in January 1554, when the extended phrase was no longer present in the text of the diet agreement, they still refused to join it due to other articles (see above, MLA, Bd. 4, 71-72). Until more sources are available, one can presume that here the extended phrase might have been only one of many causes for disagreement.

The way the text was rephrased warrants more attention, as it reveals how the authors used contemporary discourse (local and imperial) to obscure the meaning in order to obtain the towns' approval. The comparison of the four available sources where the phrase appears shows that it was at first reduced and then rephrased using a synonym that was more general and ambiguous in meaning. This was achieved because, the term "Vergleichung" (agreement) was a legal term often used in the imperial diets as a synonym of a council or any other agreement and proclaimed the end goal of the emperor's politics in the religious question (Jörgensen 2014, 211, 240-253). "Bewilligung" (approval), on the other hand, was frequently applied in the discourse of Livonian diets when referring to an approved decision (see, for example: NNM, 7/8 Bd., 341-342). Although both were synonyms, a "univocal agreement" would sound more like a reference to a general agreement in the empire and would be more acceptable, and an "approval" - more like a reference to a local decision which had negative connotations.

It has to be noted that both sentences used in the sources of the assembly in 1552 that express the agreement itself and contain this phrase, were rather general in meaning, although they stated that everyone should stay by the same religion, they did not attribute it exclusively to Lutherans, as was done in 1551 and would be done in January 1554, when the texts used the words "angenommenen Religion" ("assumed confession") (GStA PK, XX HA, HBA D, No. 1517, Bl. 9V; MLA, Bd. 5, No. 266). The pro-Lutheran appearance of the proposition and the final agreement of 1552 seems to have been created by the only explicitly Lutheran phrase in the $2^{\text {nd }}$ part of the agreement $\mathrm{t}^{13}$ which states that the people should hear the sermons: "zw dem allein selichmachenden Wordtt Gottes gehalten"14 (NNM, 7/8 Bd., 341-342) - Kreem notes, that the agreement only contains this Lutheran sounding slogans omits any detail (Kreem 2019, 460-463). However, when Archbishop of Riga Wilhelm von Brandenburg informed his brother that the assembly had made some additional decisions. He explained the fragment of interest in a way that did not suggest that the decision was explicitly pro-Lutheran. He wrote: "[...] dass es bey jetziger Religion bis zum gemeinennn generall Concil bleiben, vnd dass gotlich wardt wie Itzo Im schwanng [ = üblich, im Gebrauch], gepredigt vnd gelerett werden sollte."15 (GStA PK, XX HA, HBA D, No. 1565, Bl. 5v) Since he did not use the phrase "angenomene Religion", it is hard to tell whether he meant that the decision agreement was proLutheran. In this interpretation, the new agreement sounded like it did, in 
fact (as proclaimed in the text) just repeat the previous diet agreements of 1532, when the decision to postpone any changes until a free general church council and let everyone observe their customs was last included into the text of a diet agreement, but was meant for the "old faith". In reality, the agreement of 1552 was markedly more pro-Lutheran when compared to explicitly neutral and empire-oriented diet agreement of 1532 (ARIII, N. 304., S. 771-772; Richter, A. v. 1857, 304-305).

Thus, the agreement of 1552 was phrased rather ambiguously and generally, although it contained a Lutheran phrase and, in comparison to the previous diets, sounded more Lutheran. In context with the Interim, whether it was inspired by the Treaty of Passau or not, this return to the old diet agreements was meaningful by itself, as it proclaimed the confessional inviolability of the estates, albeit until a future decision. Lastly, although the Lutheran phrasing and meaning could serve the intentions of other involved parties, including those who supported the Protestants, the ambiguity actually benefitted the estates that were supportive of the "old faith", like the cathedral chapter of Riga.

\section{CONCLUSIONS}

In conclusion, although the assembly of 1552 had taken place when Livonia was informed about the complicated situation of the emperor and might have come in contact with the imperial discourse and the demands of there bellious princes, additional sources are needed to understand how and why the contemporary situation in the empire might have influenced Livonian politics in 1552 and the agreement of the assembly of the territorial estates, and how this was connected to the situation that was created earlier by the Augsburg Interim.

Although the agreement of Pernau could have been inspired by the events in the empire in April-June of 1552, there is a substantial evidence that the local political interests played a role in phrasing and use of the agreement. Generally, the agreement followed the structure and somewhat even the phrasing of the previous diets of 1532 and 1537, but it also contained an extended "council phrase" connected to the agreement project that was proposed in 1551. Thus, although the text was phrased to mean pro-Lutheran religious peace, it actually contained ambivalent elements. This later characteristic promised to be beneficial for the politics of the cathedral chapter of Riga.

Thus, the agreement of the assembly of the ambassadors of Livonian territorial estates and towns in Pernau in July of 1552 that was reached without the acceptance of towns was a product of contemporary political 
situation and not just an expression of the Lutheranisation of Livonia and religious freedom; moreover, its phrasing allowed to obscure the traditional "council phrase" and could have paved the way for further local negotiations on the matters of religion.

\section{ABBREVIATIONS}

AR III - Akten und Rezesse der livländischen Ständetage, Bd. 3.

GStAPK - Geheimer Staatsarchiv Preussischer Kulturbesitz (Secret State Archives of Prussian Cultural Heritage)

LNA-LVVA - Latvijas Nacionālā arhīva Latvijas Valsts vēstures arhīvs (Latvian State Historical Archives of National Archives of Latvia)

MLA - Monumenta Livoniae antiquae

NNM - Neue Nordische Miscellanen

RA - Rahvusarhiiv (National Archives of Estonia)

TLA - Tallinna linnaarhiiv

\section{LIST OF SOURCES AND LITERATURE} UNPUBLISHED SOURCES

Agreement project, [German] proposed in February 1551. Secret State Archives of Prussian Cultural Heritage (Geheimer Staatsarchiv Preussischer Kulturbesitz, hereinafter: GStA PK), XX HA, HBA D, No. 1517, p. 8.v-14.r.

Letter of Wilhelm von Brandenburg [German], 03.10.1552. - GStA PK, XX HA, HBA D, No. 1565, Bl. 1.v-8.r.

Draft of the entry by the Elder of the Great guild of Riga, Reinhold Germann, 1554, with a transcript by Johann Kristoph Brotze - Latvian State Historical Archives of National Archives of Latvia (Latvijas Nacionālā arhīva Latvijas Valsts vēstures arhīvs, hereinafter: LNA-LVVA), 214-6-100, p. 140-141.

Account of the negotiations between the ambassadors of Riga, Dorpat and Reval during an assembly in January 1555 - Tallin City Archives (Tallinna linnaarhiiv, hereinafter: TLA), 230-1-Br 14, p. 491. $\mathrm{r}-493 . \mathrm{r}$.

\section{PUBLISHED SOURCES}

Arbusow, L., Stavenhagen, O. (Hgs.), 1910. Akten und Rezesse der livländischen Ständetage, Bd. 3. Riga: J. Deubner. $1000 \mathrm{~S}$.

Brevern, G. von 1842. Schluss des Pernauschen Resesses vom Jahre 1552. Gesellschaft für Geschichte und Alterthumskunde der russischen Ostsee-Provinzen (Hg.). Mitteilungen aus dem Gebiete der Geschichte Liv-, Est- und Kurlands. Bd. 2. Riga: Nicolai Kymmel's Buchhandlung, 157-159.

Hartmann, S. (Bearb.), 2002. Herzog Albrecht von Preußen und Livland (1540-1551). Regesten aus dem herzöglichen Briefarchiv und den Ostpreußischen Folianten. (Kloosterhuis, J. und Heckman, D. (Hg.) Veröffentlichungen aus den Archiven Preussischer Kulturbesitz, Bd. 57) Köln: Böhlau. (hereinafter: Hartmann (1540-1551))

Hartmann, S. (Bearb.), 2005. Herzog Albrecht von Preußen und Livland (1551-1557). Regesten aus dem herzöglichen Briefarchiv und den Ostpreußischen Folianten. (Kloosterhuis, J. und Heckman, D. (Hg.) Veröffentlichungen aus den Archiven 
Preussischer Kulturbesitz, Bd. 57) Köln: Böhlau. (hereinafter: Hartmann (1551-1557))

Hupel, A. W. (Hgs.), 1794. Neue Nordische Miscellanen: Siebentes un Achtes Stück. Riga: Hartknoch, J. F.

Napiersky, C. E. (Hgs.), 1844. Monumenta Livoniae antiquae: Sammlung von Chroniken, Berichten, Urkunden und anderen schriftlichen Denkmalen und Aufsätzen, welche zur Erläuterung der Geschichte Liv-, Ehst- und Kurland's dienen. 4. Bd. Riga, Leipzig: Eduard Frantzen's Verlags-Comptoir.

Napiersky, C. E. (Hgs.), 1847. Monumenta Livoniae antiquae: Sammlung von Chroniken, Berichten, Urkunden und anderen schriftlichen Denkmalen und Aufsätzen, welche zur Erläuterung der Geschichte Liv-, Ehst- und Kurland's dienen. 5. Bd. Riga, Leipzig: Eduard Frantzen's Verlags-Comptoir.

\section{LITERATURE}

Arbusow, L., jun., 1921. Die Einführung der Reformation in Liv-, Est- und Kurland. (Verein für Reformationsgeschichte (Hg.). Forschungen zur Reformationsgeschichte. Bd. 3) Halle: R. Haupt.

Arndt, J. G. (Hgs.), 1753. Der Liefländischen Chronik Andrer Theil: Von Liefland unter seinen Herren Meistern, welche die alte Geschichte des Ordens und der benachbarten Völker erleutert: Sowol mit Zuziehung der gedruckten und ungedruckten Schriftsteller als fürnemlich aus einer zalreichen Menge alter Documente im Original, beglaubten Copeien und andern Abschriften zusammen getragen [..] Halle: Gebauer.

Brachmann, W., 1850. Die Reformation in Livland. Ein Beitrag zur Geschichte Livlands sowohl als der Reformation. Gesellschaft für Geschichte und Alterthumskunde der russischen Ostsee-Provinzen (Hg.). Mitteilungen aus dem Gebiete der Geschichte Liv-, Est- und Kurlands. Bd. 5. Riga: Nicolai Kymmel's Buchhandlung, S. 1-266.

Drecoll, V. H. 2000. Der Passauer Vertrag (1552). Einleitung und Edition. (Markschies, Ch. et al. (Hgs.) Arbeiten zur Kirchengeschichte. Bd. 79). Berlin: Walter de Gruyter.

Jörgensen, B., 2014. Konfessionelle Selbst- und Fremdbezeichnungen: Zur Terminologie der Religionsparteien im 16. Jahrhundert (Colloquia Augustana). Oldenbourg: De Gruyter.

Hartmann, S., 2004. Neue Quellen zur livländischen Koadjutorfehde 1555/6. Jähnig B. et al. (Hgs.). Aus der Geschichte Alt-Livlands: Festschrift für Heinz von zur Mühlen zum 90. Geburtstag. Münster: Lit, S. 275-306.

Kreem, J., 2014a. Das Augsburger Interim in Livland. Evangelische und Altgläubige in den baltischen Landen in der Mitte des 16. Jahrhunderts. Braun, K.-H. et al. Hgs. Historisches Jahrbuch, Jhg. 134. Freiburg: Alber, S. 121-141.

Kreem, J., 2014b. Die Religionsfrage auf den livländischen Ständeversammlungen 1522-1558. Mentzel-Reuters, A., Neitmann, K., Hgs. Preussen und Livland im Zeichen der Reformation. (Tagungsberichte der Historischen Komission für Ost- und Westpreussischen Landesforschung, Bd. 28). Osnabrück: fibre Verlag, S. 183-208.

Kreem, J., 2019. Die Reformationszeit. Brüggemann, K. et al. (Hgs.). Das Baltikum. Geschichte einer europäischen Region. Bd. 1. Von der Vor- und Frühgeschichte bis zum Ende des Mittelalters. Stuttgart: Hiersemann Verlag, S. 632-462.

Lange, T., 2014. Zwischen Reformation und Untergang Alt-Livlands: der Rigaer Erzbischof Wilhelm von Brandenburg im Beziehungsgeflecht der livländischen Konföderation und ihrer Nachbarländer, 2 T. Hamburg: Verlag Dr. Kovač.

Massing, M., 2019. Die Reformationsversuche im Erzbistum Riga in den 1540er und 1560er Jahren. Radosław Biskup et al. (Hgs.). Die Kirche im mittelalterlichen Livland 
(Ecclesia clerusque temporibus medii aevi. Vol. 5). Toruń: Widawnictwo Naukowe Uniwersytety Mikołaja Kopernika. S. 245-272.

Müller, U., 2014. Erzbischof Wilhelm von Riga und die Reformation in Livland 15351563. Mentzel-Reuters, A., Neitmann, K. (Hgs.). Preussen und Livland im Zeichen der Reformation. (Tagungsberichte der Historischen Komission für Ost- und Westpreussischen Landesforschung, Bd. 28). Osnabrück: fibre Verlag. S. 241-343.

Niitemaa, V., 1949. Die undeutsche Frage in der Politik der livländischen Städte im Mittelalter. Helsinki: Suomalainen Tiedeakatemia.

Novikova, M. Rīgas arhibiskapijas zemes kārtu politiskā pozīija laikā no Meklenburgas Kristofa ievēlēšanas par koadjutoru lìdz Brandenburgas Vilhelma nāvei (1556-1563). Magistra darbs. Rīga: Latvijas Universitāte, 2020.

Pistohlkors, G. v., 1994. Hg. Deutsche Geschichte im Osten Europas. Baltische Länder. Berlin: Siedler Verlag.

Richter, A. v., 1857. Geschichte der dem russischen Kaiserthum einverleibten deutschen Ostseeprovinzen bis zur Zeit ihrer Vereinigung mit demselben. Th. 1, Bd. 2. Die Zeiten der reingermanischen Entwicklung, 1158-1562. Riga: Kymmel.

\section{NOTES}

${ }^{1}$ Parts of this article are based on the results of author's master's thesis (Novikova 2020).

2 "[...] for the whole land."

$3 * *$ - mark a paratextual fragment.

4 "[..] in return the lord Archbishop and chapter are able to and are willing to tolerate an.d permit, that the current adopted religion *together with Christian ceremonies* would be observed in the cathedral church so long as a free Christian general or national church council or the common lords, estates and towns of the land of Livonia decide to introduce and agree upon a change in Religion *that will not be contrary to the God's word*."

5 "[...] here should be stated "till a Christian general church council". The canons of the cathedral chapter together with all of their supporters were unwilling to agree to this, rather [they demanded] it should state "till a univocal free agreement"."

${ }^{6}$ See No. 4.

7 "to act according to the accepted by the land [according to diet agreements] (that every lord, estate and town should be left undisturbed and unchallenged till a free Christian church council and a univocal approval) in matters that concern the religion and the word of God [sermon and pastoral care]".

8 and so much concerns the religion and the word of God [sermon and pastoral care], that everyone, of high or low class, in and by the same should be left undisturbed and unchallenged till a free Christian church council and a univocal agreement according to the concluded diet agreements.

${ }^{9}$ See No. 5 .

10 "[...] that [the discussion of] some articles concerning the religion should be postponed till a univocal agreement of lords, estates and towns of the land".

11 " [...] that the towns must give a reversal document, wherein it will approve and promise, that it would agree and act accordingly, if the lords of this land would decide to introduce a change in church ceremonies and service (as if they have accepted the Interim) here in this land."

${ }^{12}$ See No. 4. 
${ }^{13}$ For the analysis and systematics of the Livonian agreements on the matters of religion, see Kreem 2014a.

${ }^{14}$ The second part of the agreement: "[...] und so viel Mangel vnd Gebrehcen der vorfallenen Kirchen, Gotesheusern, das dieselbigen hinfurth mith gotsforchtigen frommern Pfarhern vnd Dienern verßorgett vnd vorsehen werden mochten, vnd das arme Paurßvolck, so woll der Deutsche, von en groben Jrthummen, Zeuberej vnd dergleichen Gotslesterung, welche billick bej dem hogsten zw straffen, abgeleiteth, vnd zw dem allein selichmachenden Wordtt Gottes gehalten werden mochten vnd das ein jeder gesitliches vnd weltliches Standes, auch die Ritterschaft vnd Stette, ein jeder beßonder, bej ßeiner hohen Ubrigkeitt mith vleiße vorschaffe, vnd zu uorbieten haben soll, das jn deme wie es vor dem almechtigen zuuorantworten ßein will, nottwendigk Auffsehens vnd Vorßorge geschehe." Translation: "and concerning the lacking and defects of ruinous churches, temples, that these hereafter should be provided and equipped with Godly and devout pastors and servants, and the poor peasants, as well as the Germans, would be diverted from mistakes, witchcraft and similar blasphemy, which should be strictly punished, and kept under the saving word of God. And that everyone of clerical or secular status, including the nobility and towns, everyone by himself, would diligently ask and propose their lords that this matter should receive the necessary attention and care in a way that they will be able to be accountable for in front of the almighty."

15 "[...] that it should be left by the current religion and the sermons should be preached and learned as is customary until a general church council." 


\title{
PĒRNAVAS 1552. GADA KĀRTU SAPULCES RECESA LËMUMS RELIG̣IJAS JAUTĀJUMĀ RĪGAS ARHIBĪSKAPIJAS KĀRTU POLITIKAS KONTEKSTĀ
}

\author{
MARGARITA NOVIKOVA \\ Mg. hist. \\ E-pasts: margarita.novikova@inbox.Iv
}

\begin{abstract}
ANOTĀCIJA
Raksts pievēršas mazpētītam Livonijas reformācijas vēstures posmam, aplūkojot 1552. gada Livonijas kārtu sapulces recesu, tā priekšvēsturi un saiknes ar Rīgas strīdu 1549.-1554. gadā. Izpētes rezultātā tiek secināts, ka recess tika noslēgts starp Livonijas domkapitulu un bruṇniecības pārstāvjiem; lēmums religíijas jautājumā formulēts Rīgas arhibīskapijas kārtu pārstāvju ietekmē, un tā interpretācijā ir svarīgs tā dēvētais koncila frāzes paplašinājums, jo ar tā palīdzību Rīgas domkapituls varēja turpināt savu iepriekš un vēlāk piekopto politiku un mēgināt izveidot sev plašāku rīcību telpu strīdā par sekularizētajiem baznīcas īpašumiem Rīgā.
\end{abstract}

Atslēgas vārdi: Reformācija, Livonija, Rīgas strīds, Pērnavas 1552. gada kārtu sapulce, ticības brīvība, Rīgas domkapituls.

\section{KOPSAVILKUMS}

Raksta mērḳis ir analizēt lēmumu attiecībā uz reliǵiju, kas tika pieñemts sapulces laikā, kontekstā ar laikmetīgo politisko situāciju vai, precīzāk, Rīgas arhibīskapijas kārtu politiku. Raksts pievēršas 1552. gada kārtu sapulces recesa radī̌anas apstākḷiem, izdevējiem un avotiem, nosaka formulētā lēmuma teksta politisko kontekstu un mērḳus. Rezultāti iegūti, izmantojot avotu kritiku, teksta analīzi un salīdzinošo analīzi, vēsturiski ǵenētisko metodi un interpretācijas metodi.

Izpētes rezultātā tiek secināts, ka recess tika noslēgts starp Livonijas domkapitulu un bruņniecības pārstāvjiem; lēmums reliğijas jautājumā formulēts Rīgas arhibīskapijas kārtu pārstāvju ietekmē un tā interpretācijas procesā ir svarīgs t. s. "koncila frāzes" paplašinājums, jo ar tā palīdzību 
Rīgas domkapituls varēja turpināt savu iepriekš un vēlāk piekopto politiku un mēgināt izveidot sev plašāku rīcību telpu strīdā par sekularizētajiem baznīcas ìpašumiem Rīgā. 


\title{
BEVERĪNAS MEKLĒJUMU ATRISINĀJUMS
}

\section{GINTS SKUTĀNS}

Mg. hist.

E-pasts: skutans@inbox.Iv

\begin{abstract}
ANOTĀCIJA
Vairāk nekā simt piecdesmit gadu ilgst "Livonijas Indriḳa hronikā" pieminētās Beverīnas pils meklējumi, taču līdz pat šim brīdim nav bijis iespējams nonākt pie vienota slēdziena. Pašlaik arheologiisko izrakumu un rakstu avotu izpētes rezultātā vairākumu pils novietojumu vietu Valmieras apkārtnē iespējams noraidīt, jo šai apvidū nav konstatējama 11.-13. gadsimta apdzīvotība. Izanalizējot Kauguru Pekas kalna uzbūvi un izrakumu materiālu, nocietinājuma pastāvēšanas laiku izdodas attiecināt tikai uz 14.-16. gadsimtu. Līdz ar to Beverīnas lokalizāciju iespējams veikt vienīgi atlikušajā Raunas Tanīsa kalnā, kurš atbilst visiem hronikā fiksētajiem kritērijiem. Arheologiiskie pētījumi pilskalnā atrod nozīmīgu vēlā dzelzs laikmeta nocietinājumu, bet piegulošā novada apdzīvotībai raksturīga blīva arheolog̉isko pieminekḷu koncentrācija. Tā kā nav prognozējamas jaunas vēsturnieku publikācijas Beverīnas meklējumu turpināšanai, šo pagātnes noslēpumu varam uzskatīt par atrisinātu.
\end{abstract}

Atslēgas vārdi: Beverīna, pilskalns, pils, vēsturiskā geogrāfija, Livonija, "Indriḳa hronika", viduslaiki.

Beverīnas pils atrašanās vietas mīkla Latvijas historiogrāfijā ir palicis neatbildēts jautājums, bez kura nav iespējams izprast Vidusvidzemes vēlā dzelzs laikmeta ǵeogrāfiju. Pils piecpadsmit reizes pieminēta "Indriķa hronikā" (turpmāk tekstā hronika) kā Tālavas nocietinājums Beverin, piederīgs kompaktai letu grupai (turpmāk tekstā latvieši) Gaujas vidustecē. Tie aizṇēma kādu biezi apdzīvotu, zemkopībai piemērotu apvidu un apzīmēti hronikā kā Letti de Beverin, Bevernenses. Beverīnas vārds ir ieņēmis zīmīgu vietu Latvijas kultūrvēsturē, un īpašu oreolu tam pieškiir hronikā aprakstītā priestera muzicēšana 1208. gada aplenkuma laikā. Jau vairāk nekā simt gadu pils meklējumi veido stūrakmeni Valmieras, Trikātas un Vijciema 
novadpētnieku aktivitātēs. Starpkaru gados lokalizācijas aptvēra septiñas vietas - Valmieru (pilsdrupas, Lucas kalns), Kaugurus (Pekas kalns), Rubeni (Vaidavas pilskalns), Trikātu, Vijciemu, Burtniekus un Raunu (Tanīsa kalns). Taču pēdējos trīsdesmit gados pils novietojumu skaits ir dubultojies, turpinājusies polemika presē, organizēta konference un priekšlasījumi, notikušas ekskursijas un talkas. Sastopami arī iracionāla un ezoteriska rakstura novietojumi, diskutēts par Beverīnas dziedoṇa un viña instrumenta noslēpumu. Pašlaik Beverīnas meklētāju loks ir stipri sašaurinājies, bet arheolog̣isko izrakumu un rakstu avotu izpētes rezultātā Gaujas labā krasta novietojumi zaudējuši savu aktualitāti. Adekvāto meklējumu lokā palicis trīsstūris starp Raunu, Valmieru un Trikātu. Raksts tapis ilgstošas pētniecības gaitā un ir noformēts akadēmiski korekti, lai starp atlikušajiem pretendentiem pārliecinoši pamatotu galīgo risinājumu.

Pētijums ilgst trīsdesmit gadu, balstās uz hronikas (IH 1993) un arheolog̣ijas ziṇu salīdzināšanu, veicot arī objektu apsekošanu dabā. Pašlaik Ziemeḷvidzemē un piegulošajā Igaunijā ir apsekoti visi viduslaiku nocietinājumi, izpētìtas rakstos pieminēto kauju un ceḷu vietas. Jānorāda, ka hronikā par Beverīnu ir daudzpusīgs ziņu klāsts, atšķiirībā no Sateklas vai Metimnes. Mēs varam noteikt attālumus līdz Cēsīm un Sakalai, tāpat zināms, ka pils atradusies nozīmīgu ceḷu tuvumā, jo no šejienes sākti vismaz trīs karagājieni uz Igauniju un pati pils divas reizes aplenkta. Skaidrota robežligumos starp Zobenbrāḷu ordeni (turpmāk tekstā ordenis) un Rīgas bīskapu pieminēto Ziemel̦vidzemes vietu ǵeogrāfija (SLVA 79; Abuls 1924, 45), kura l̦auj izprast ar Beverīnu saistīto teritoriju sadalǐšanas principus 1209.-1224. gadā. Izmantoti arhibīskapa Fromolda izdotie dokumenti (LGU I, 90-91), ieraksti Rīgas parādu grāmatās (RS, 1-119), caurskatīti Livonijas un Hanzas pilsētu tirdzniecības dokumenti. Apzinātas 16. gadsimta cel̦otāju Zamuēla Kīhela (Spekke 1995, 112-115) un Heinriha Štādena atmiņas (Dunsdorfs, Spekke 1964, 297), kuras atklāj muižu pastāvēšanas faktu divos Beverīnas meklējumu apvidos. Apzinātas arī arheolog̣ijas materiālu ziņas par senākajiem un mūsdienu izrakumiem pils meklējumu vietās.

Beverīnas meklējumu pirmskara historiogrāfija sīki apskatīta līdzšinējās publikācijās, kuras brīvi pieejamas internetā (Abuls 1924; Žīgurs 2003 u. c.), tāpēc aplūkošu tikai jaunākās pēdējo trīsdesmit gadu norises. Arheologs Pēteris Stepiņš vēl padomju laikā atjauno Beverīnas meklējumus (1983, 1992, 1993), novietojot to Vaidavas pilskalnā. Arī Ēvalds Mugurēvičs vairākās publikācijās (1965., 1993., 1999. gadā) pamato savu Trikātas variantu (IH 1993, 376), līdz 1993. gadā izveidojas polemika ar P. Stepiṇu. Pirmais jautājuma kopsavilkumu 1991. gadā publicē Juris Urtāns, aprakstot Ziemelvidzemes pilskalnus (Urtāns 1991, 9-12, 38). Taču no paša izvirzìtās Viḷumu versijas (1988) pētnieks tūlin atsakās, jo skaidras pilskalna pazīmes kalnā neizdodas konstatēt. Publikācijas autors Beverīnas pili līdz 


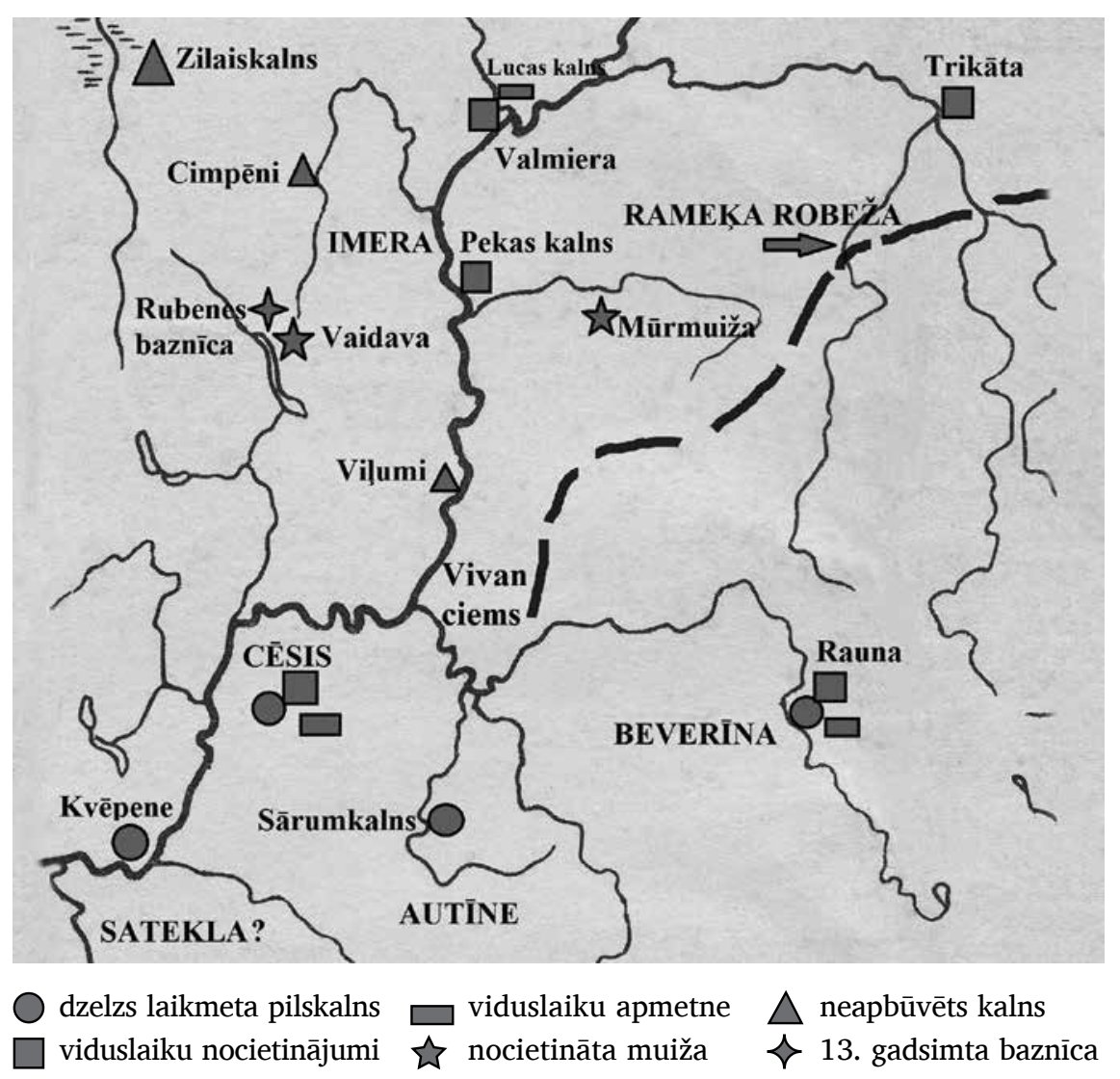

1. attēls. Beverīnas galvenie novietojumi un publikācijā pieminētās 13.-16. gadsimta vietas Gaujas vidustecē. Izstrādājis G. Skutāns 2021. gada maijā

Figure 1. The main locations of Beverina and the $13^{\text {th }}$ to $16^{\text {th }}$ century areas in the middle reaches of the Gauja noted in the publication. Developed by G. Skutāns in May 2021

šim saistījis ar Raunas Tanīsa kalnu, bet Sateklu ir mēginājis novietot dažādās vietās (Kvēpene, Lìgatne u. c.) rietumos no Cēsīm (Skutāns 1992, 65; 2010). Lai arī meklējumi ilguši vairāk nekā trīsdesmit gadu periodu, autors vēl arvien nevar dot izsmel̦ošu atbildi par Sateklas pils novietojumu. Muntis Auns Beverīnu novietoja Cimpēnu pilskalnā (1996), taču šo versiju pats vēlāk atzina par pārsteidzīgu. Novietojumus un to argumentāciju ir uzskaitījis Edgars Žīgurs, kura veidotais pētniecības apskats ir plašākais par šo tēmu. Savā studiju darbā viņš piedāvā lokalizācijām novērtējuma tabulu - "Beverīnas hipotēžu verifikāciju”, kurā izvirzās Pekas kalns un Rauna (Žīgurs 2003, 1. pielikums). 2001. gadā notika Beverīnas meklējumu kulminācija, Valmieras muzeja organizētā konference "Es meklēju Beverīnu". Tajā piedalījās Guntis Zemītis, Tālis Pumpuriņš, Gints Skutāns, Andrejs 
Lucāns, Eduards Lauris, Valentīns Klešniks, Ojārs Ozolinš u. c., taču konferences materiāli ir palikuši nepublicēti. Turpināja pastāvēt arī Artūra Gobas (1990) un Ojāra Ozolin,a atbalstītā Vijciema versija, kura pašlaik zaudējusi jebkādu nozīmi. Ap 1990. gadu O. Ozoliņš tomēr maina uzskatus par labu Valmieras apvidum, klusībā cerēdams Gaujas kreisajā krastā atklāt jaunu, Beverīnai piemērotu pilsvietu. Valmieras versiju noliedz ilgstošā pilsdrupu arheoloǵiskā izpēte - senākā 1937.-1939. gada, tā arī padomju laika (Berga 2018, 21; 34) un it sevišḳi 2018. gada izrakumi (Brūzis 2019, 47). Izpētot lielu daļu no Valmieras pils teritorijas, netika atrasta pirmsvācu apdzīvotība, līdz ar ko iespējams pilnībā noraidīt Hermaṇa Enzeliṇa (1935) un A. Lucāna (Lucāns 1996, 4) paustos uzskatus. Meklējumu saistībā E. Lauris Trikātas pilsdrupās saskata senu pilskalnu, par ko atkārtoti rakstījis vietējos izdevumos (Lauris 2019, 6 u. c.).

Beverīnas lokalizācijas varam sadalīt divās grupās, no kurām nopietnākajai saskaṇā ar hronikas ziṇām (IH XII: 6) atbilst samērīgs attālums līdz Cēsīm (ne vairāk kā 30-35 kilometri) un pilskalna ierīkošanai atbilstoša vieta. Meklējumu priekšgalā nonāk deviṇi kandidāti (sk. 1. attēlu) - Kauguru Pekas kalns, Rauna, Trikāta, Rubene, Valmieras pilsdrupas un Lucas kalns, Zilaiskalns, Viḷumi (Vaidavas pagastā) un Cimpēni. Pašlaik apzinātas līdz pat divdesmit Beverīnas novietojuma versijas, taču pusei no tām argumentācija nav nopietni uztverama. Aston,os no ticamākajiem Beverīnas novietojumiem ir notikuši dažādas kvalitātes arheologiskie izrakumi. Ja vien tiktu apkopoti agrāko izrakumu pārskati un veikti nopietni datējumi, šis vēstures noslēpums jau sen būtu atrisinājies.

Pētījumi Valmierā, Vaidavā, Cimpēnos un Trikātā nav devuši uz 12.13. gadsimta miju attiecināmus atradumus. Apdzīvotības pazīmes netika atrastas Cimpēnos (Ballod 1911, 26) un Zilajā kalnā (1874., 1973., 2020. gada izrakumi), bet t. s. Viḷumu pilskalna smilšu atsegumos nav kultūrslān,a pazīmju. Pekas kalns vēstures literatūrā tiek atzīts par 12.13. gadsimta nocietinājumu, taču mūsdienu pētniecība (Ose, Caune 2004, 244) šeit konstatē izteiktu 15.-16. gadsimta apbūvi, tiesa gan, neapstrīdot Franča Baloža uzrādītā 12.-13. gadsimta slāṇa pastāvēšanu. No jauna ir jāpārbauda viņa atzinumu objektivitāte, jo pētnieks tolaik bija ieinteresēts pamatot sava tēva Voldemāra Baloža uzskatus (Ballod 1910; 1911; Balodis 1928). F. Balodis 1909. gadā, būdams arheologijas students, pievēršas pilnīgi jaunai tēmai - pilskalnu pētniecībai, kura šai laikā visu Baltijas guberņu mērogā spēra pirmos soḷus.

Beverīnas meklējumos līdz šim maz akcentēta pilskalnu tipologijas metode, kuru Ernests Brastiņš veido, balstoties uz pilskalnu uzmērīšanas pieredzi. Tā l̦auj pēc ārējo pazīmju kopsakarības dzelzs laikmeta koka pilis nošḳirt no 13.-15. gadsimta vācu nocietinājumiem, 16.-17. gadsimta muižu vietām, karaspēka nometnēm un skanstīm. Pēdējos sešdesmit gados 
arheolog̣iski pētīti arī 13. gadsimtā vācu ierīkotie viduslaiku nocietinājumi Krusta kalns Siguldā (Jemeljjanovs 2010, 88), Liepupes pilskalns (Kraukle 2016, 188), Žagares Zvelgaiču kalns (Vasiḷausks 2014, 99) u. c. Tie parasti tiek pieskaitīti dzelzs laikmeta pilskalniem, jo tajos akmens mūrējumi nav bijuši vai arī vairs nav atpazīstami zemes virskārtā. No vietējo tautu nocietinājumiem tie atšķiras ar regulāras formas plakumu, zemu vaḷnu uzbērumiem un aizsarggrāvjiem nocietinājuma perimetrā. Vadoties pēc šādām pazīmēm, Beverīnas meklējumu rajonā kā vācu laika koka nocietinājumus varam identificēt Dzērbenes Augsto kalnu, Cērtenes un Naukšēnu pilskalnu (Brastiņš 1930, 96, 182, 208). Atšḳirīga un kompakta vēlā dzelzs laikmeta nocietinājumu grupa izvietojusies krietni dienvidos no Valmieras - Cēsu un Straupes apkārtnē. Šiem pilskalniem vērojams pavisam citu pazīmju kopums - visvieglāk pieejamā pusē ierīkots ap desmit metru augsts priekšvalnis, plakums ir iegarens un neregulārs, pārsvarā gadījumu kalnā uziet varēja pa kreiso pusi. Tādas vērojamas Straupes Kranču kalnā, Kvēpenē, Sārumkalnā, Tanīskalnā (Brastiņš 1930, 79, 87, 90-93) un Dzērbenes Ketu pilskalnā (Urtāns 1995, 23). Gaujas labajā krastā un līdz pat Igaunijai 9.12. gadsimta nocietinājumus, apmetnes un apbedījumus arheologijijas kartes neuzrāda (LA 178-179), tas pats vērojams vēl 15 kilometru aiz robežas (EE, 20. attēls). Ir jāpārvērtē šìs teritorijas apdzīvotības blīvums, celtniecības un apbedījumu tradīcijas.

No Gaujas labā krasta versijām apskatīšu tikai Beverīnas lokalizāciju Rubenē, jo zināms stāsts par Livonijas kara laika zemes nocietinājuma pastāvēšanu tieši šajā vietā. Vācu ceḷotājs Zamuēls Kīhels, braukdams no Rīgas uz Tērbatu trīs gadus pēc Livonijas kara beigām, šeit meklē naktsmājas un atstāj sīku aprakstu šai Beverīnai (Spekke 1995, 114). Vaidavas pilskalns atrodas pavisam netālu no Rubenes baznīcas, Tērbatas lielcela tiešā tuvumā. Izrādās, ka tajā nocietinātu muižu ierīkojis Melhiors Hēfelns (Melchior Höfeln), kurš pēc 1562. gada Vidzemes pievienošanas Polijai ir kḷuvis par karaḷa vasali. Jaunā muiža varēja tikt uzcelta pret krievu iebrukumiem Livonijas kara ceturtajā posmā (1578-1583), kad Cēsis jau bija atgūtas un krievi atspiesti uz Tērbatu. Kīhels 23. jūlijā izbrauc no Rīgas un nakšn,o pie Baltezera, 24. jūlija vakarā apmetas uz lauka Inciema tuvumā, bet nākamajā rītā dodas Valmieras virzienā un nonāk ceḷu krustojumā pie Lielstraupes skolas. Tālāk seko Beverīnas tēmai tik vērtīgais naktsmìtnes apraksts. "[..] Tā nu vakarā mēs nonācām pie kāda muižnieka mājas, kas visapkārt apn,emta ar zemes val,niem; lai tajā varētu patverties pret uzbrukumu, ticis ierīkots pacel̦amais tilts. [..] Šo muižu sauc par Jauno muižu, un tās muižnieku par Melhioru fon Hēfelnu, kurš ir karavīrs un atrodas Polijas k,ēniņa dienestā. Lai gan šî nocietinātā vieta maz nostiprināta (ap to bija tikai zems velēnu valnis), tomēr pagājušā kara laikā maskavieši to nekad neesot varējuši ien,emt; daži apkārtējie 
ciemati, kas atrodas tuvumā, tur nobēdzināja savu mantu, un arī ḷaudis tur patvērās, tā kā [šis cietoksnis] bijis pienācīgi apgādāts ar kareivjiem, lielgabaliem un pulveri." (Spekke 1995, 114-115)

Šì Jaunā muiža pieminēta 1601. gada arklu revīzijā Mujānu pilsnovadā (Melchior fon Höwelen un Newe hoff; Švābe 1933, 549), kur Hēfelns pārvalda īpašumu ar vairāk nekā simt saimniecībām (Ķiegeeḷu, Vaidavas, Podzēnu muiža). Tā kā lēņa novads kara gaitā ir postīts un nedrošs pret sirojumiem, viņš spiests ierīkot jaunu nocietinātu mītni priežu silā, stāvā ezera krastā. Muižas pastāvēšanu apstiprina Jāņa Apala 1986. gadā arheoloğiskie izrakumi, kuri tika veikti trijās atsevišḳās plakuma vietās. Atradumi visur bija vienveidīgi naglas, ripas keramika, kiieǵel̦u lauskas (Apals 1988, 18). Apskatot dabā nocietinājuma uzbūvi, atklājas šaujamieročiem pozīcijām paredzēti, specifiski uzbērumi un trīsstūrveida bastions. Livonijas kara beigu posma zemes nocietinājumi Latvijā pilskalnu vidū vēl nav izdalīti atsevišḳā kategorijā, taču Ziemeḷvidzemē varu uzrādīt vēl vismaz trīs citu analogu esamību.

Trikātas un Kauguru novietojumam priekšroku deva 2009. gada teritoriālā reforma ar Beverīnas novadu, līdz ar ko tālāko meklējumu gaita tika apgrūtināta. Nav viegli no vēstures pozīcijām apstrīdēt administratīvi deklarētu faktu un pārliecināt vietējo sabiedrību par kārtējo pārpratumu, kurš turklāt nākamajā reformā atkal ticis svītrots. Vēl nesen Trikātu atbalstīja arī Latvijas arheolog̣ijas autoritātes - Ēvalds Mugurēvičs un Jānis Graudonis, radot nepamatotus pārpratumus. Jānorāda, ka padomju laikā E. Mugurēvičs necentās akcentēt tādu nevēlamu personu kā F. Baloža un E. Brastiņa pārstāvētās Beverīnas versijas. Diemžēl Trikātu noliedz pats galvenais arguments - 1208. gadā fiksētais nelielais attālums no pils līdz Cēsīm (IH, XII: 6), kurš Trikātas gadījumā ir vairāk nekā četrdesmit kilometru. Tas ievērojami pārsniedz hronikā aprakstītā karaspēka maršruta limitu, jo ziṇnesim vēlā rudenī, tumsas laikā bija jāveic ceḷš līdz Cēsīm, kurā vēl kādu laiku tika pulcināts karaspēks. No rīta visi atgriezās atpakal, pilī un tad visu nākamo dienu dzenas pakal igauņiem, bet vakara tumsā uznāca stiprs aukstums un ceḷš sasala. Trikātas virzienā tas summētos līdz pat simt kilometriem, kas vismaz divas reizes pārsniegtu diennaktī fiziski iespējamo jātnieku pārgājiena apjomu. N̦emot vērā Trikātas novietojumu Gaujas kreisā krasta tuvumā, savāds izskatās ziņu trūkums par upes šḳērsošanu sala apstākḷos. Trikātas pilsdrupās izrakumi ir notikuši jau 1889. gadā (Lēviss 1891, 39), un nekas nenorādīja uz koka apbūves pastāvēšanu. Trikātas mūra pils varētu būt celta tikai 15. gadsimtā (Ose, Caune 2004, 511), bet 12.-13. gadsimta koka nocietinājumu atrašanās pašā Strenču meža masīva malā ir nelog̣iska. Jebkurā brīdī kaiminin - igauṇi un krievi - varēja no mežiem pēkšn,i uzbrukt un pili nodedzināt.

Pateicoties F. Baloža centieniem, ir izveidojusies nepamatota pārliecība par Pekas kalna apdzīvotību vismaz no 12. gadsimta. Šeit ir skaidra 
F. Baloža tēva V. Baloža virzošā loma, kurš vēlējās novietot Valmieras tuvumā gandrīz visas nozīmīgākās pilis - Autīni, Beverīnu un Metimni, kā arī paša iztēles uzburto Imeras pili “jaunatklātajā" Cimpēnu kalnā. Pārskatot izrakumu aprakstu (Ballod 1911, 9-14), ir jāpārvērtē kalna senākā slāņa datējums ar 12.-13. gadsimtu. Pilskalna uzbūvē un izrakumu materiālā konstatēta virkne īpatnību, kas neatbilst dzelzs laikmeta nocietinājumiem: 1) plakumam ir regulāra četrstūra forma; 2) plakuma perimetru aptver zems pakavveida valnis trijās apdraudētākajās malās (mūsdienās izzudis); 3) uzeja kalna ziemeḷu pusē ir ierīkota pretēji pilskalnos raksturīgajam principam (t. i., lai vairoga neaizsargātā, labā puse, uzbrūkot būtu pavērsta pret nocietinājumu); 4) sānsienas veido divas paralēlas stāvkoku žoga rindas, kas ierīkotas apmēram piecus metrus no plakuma malas; tām analogi atrodami tikai viduslaiku izrakumu materiālos - Tanīsa kalnā u. c. (Balodis 1928, 22); 5) atrasta guḷūves celtne, kurai apkures pusē bija ḳieǵeḷu mūrējums; 6) atrasti bronzas piekariņi un, iespējams, durvju cilindriskā slēdzene ar cemmi (Ballod 1911, 9), kam paralēles saskatāmas Lucas kalna vācu laika atradumos (Berga 2018, 30). Šāda slēdzene var kalpot par izškirošo norādi, kas l,autu jau pavisam droši apšaubīt senākā slān,a saistību ar dzelzs laikmetu. Atradumi senākajā slānī raksturīgi drīzāk 13.-14. gadsimtam, jo savietojami ar tuvējā Lucas kalna materiālu (Berga 2018, 21). Publikācijā nav attēlots neviens no datēšanai derīgajiem priekšmetiem - nažiem, cirvjiem, pakavsaktām, ķemmēm, vārpstiņām u. c., tāpēc atliek cerēt vienīgi uz orig̣inālu izpēti Maskavā, Valsts vēstures muzejā. Atradumu vidū trūkst militāra rakstura priekšmetu - šḳēpu, bultu un arbaletu uzgalı -, kas apliecinātu pēc hronikas zināmās cīn,as ap Beverīnu. Par skaidru viduslaiku apdzīvotību liecina nocietinājumu uzbūves īpatnības un kopējais atradumu spektrs, līdz ar to F. Baloža apgalvojums par vēlā dzelzs laikmeta slāni šeit nevar tikt zinātniski argumentēts (Balodis 1928, 14).

13. gadsimtā Pekas kalnā vai paša lielceḷa malā, kurš vēl mūsdienās atpazīstams Gaujas kreisā krasta terasē, varēja tikt ierīkota nenocietināta mītne - naktsmītne ordeņa laudīm. Tolaik nepārtraukts meža masīvs no Kauguriem pletās līdz pat Valkai, un tajā ceḷiniekiem bija sagaidāmi dažādi apgrūtinājumi - aukstums ziemā, plēsīgi zvēri, siena trūkums, laupīšanas u. c. Ordeņbrāliem bija vajadzīga arī nocietinātu atbalsta punktu līnija ceḷā no Cēsīm uz Igauniju, un tādi tiek ierīkoti 14. gadsimtā, kuri viens no otra atrodas dienas pārgājiena attālumā - Kauguru Pekas kalnā (vēlāk Valmiera), Burtniekos, Rūjienā (vai Naukšēnos), Karksi Igaunijā. Vēlāk, 14.-15. gadsimtā, kalns pārtapa par nocietinātu ordeņa ārpilsētas muižinuu, kuras atliekas atraka un izpētīja F. Balodis. Ar muižas pastāvēšanas laiku saistāmi raksturīgie atradumi - ḳieǵeḷi, naglas, dakstiņi, keramika, stikli un, galvenais, uz 16. gadsimtu attiecināmie krāsns podiṇi. Iespējams, ka šĩ ir vēl 1601. gadā pieminētās Ūdrenes vakas (Švābe 1933, 546) muižas 
vieta, kurai robežas sakrīt ar vēlākās Kauguru muižas un pagasta aprisēm. No tās uz austrumiem, Miegas upes krastos atrodam Voldenses ciemu (Woldenschen; Švābe 1933, 543). Abu nosaukumu etimologiju varam saistīt ar divām Pekas kalna tuvumā esošajām Gaujas vecupēm. Ja Ūdrene skaidri saistāma ar latviešu ūdrs, otra viegli izskaidrojama ar vācu valodas wald-see (tulkojumā - mežezers).

Valmieras pirmsākumi 13.-14. gadsimtā varēja būt vācu tirgotāju un amatnieku nodibināts atbalsta punkts satiksmei ar Novgorodu, kuru varam piesaistīt Lucas kalna apmetnei (Berga 2018, 21). Taču arheologe Tatjana Berga to raksturo kā vietējo iedzīvotāju - amatnieku un latviešu strādnieku dzives vietu (Berga 2018, 30). Ja Lucas kalns bija tirgotāju apmetne, tad nepilnus desmit kilometrus attālais Pekas kalns uzrāda acīmredzamu saistību ar ordeni. Šāda šķirta apmešanās nav pārsteigums, jo tikai 1330. gadā ordenim izdodas pārvarēt Rīgas pilsētu un sākt kontrolēt Novgorodas tirdzniecību. Jānorāda uz atklājumu, ka 18.-19. gadsimta kartogrāfiskajā materiālā varam atrast Novgorodas senākās tirdzniecības trases pēdas, kas uzrāda ziemas ceḷa trasei sākumu tieši Valmierā. Tā, piemēram, K. Rikera Livonijas guberņas kartē (C. G. Rücker, 1839) vēl ir atpazīstams 12.-15. gadsimta ziemas ceḷš maršrutā Ķeiži-Jērcēni-Ērǵeme. Pie pilsētas Gaujā atradās Kazu krāces, kuras jūras virzienā ir pēdējais vērā ṇemamais šḳērslis, tāpēc uz Rìgu pavasarī varēja nokḷūt arī pa drošu ūdensceḷu.

Mūrmuižas vietā izdodas lokalizēt vēsturē nezināmu 16. gadsimta muižiņu - Volfarti (Wolphart, Wolgarten u. c.), kura kalpoja par ordeņa mestra ārpilsētas rezidenci. Tajā kopš 1540. gada mestrs Hermanis Brigenejs ir apstiprinājis vismaz astoṇus dokumentus (LGU II, 799), bet Livonijas kara priekšvakarā tiek uzsākta tās centra apbūve, no kuras vēl tagad saglabājusies vēsturiskā mūra ēka (Ose, Caune 2004, 341). Par Volfartes un tuvējās Valmieras apkaimes īpašnieku, ordenim sabrūkot, kḷūst Johans Bukhorsts. Viņš ir bagāts un ietekmīgs Livonijas muižnieks (LGU I, 808), dokumentos un hronikās pieminēts vismaz no 1524. gada līdz pat Livonijas kara sākumam. Škiet, ka augstmanis kara laikā iet bojā, un drīz pēc 1560. gada par tā īpašuma pārvaldnieku tiek pieņemts Heinrihs Štādens, gados jauns vācu dēkainis (Dunsdorfs, Spekke 1964, 297). Mūrmuižā saimnieko J. Bukhorsta atraitne, pēc kuras otrajām laulībām no Vācijas ierodas Bukhorsta radinieks un saņem mantojumu. Dokumentos nav konsekvences šì uzvārda rakstībā Buckhorst, Bockhorst, Buckhorsten u. c. (LGU II, 808; Švābe 1933, 542), tāpat arī latviski to varēja izrunāt dažādos variantos, kā Bokarts vai pat Bekerts. Tā kā vietējie iedzīvotāji pilsvietu no seniem laikiem sauca par Bekas vai, visdrīzāk, Beku kalnu (Ballod 1911, 24; Enzeliņš 2019, 292), tad nosaukums Pekas kalns var izrādīties V. Baloža patvalịigi izveidota vietvārda pārskaņa. Šāda forma viņam kalpoja kā būtisks pierādijjums Beverīnas novietojumam, jo saskanēja ar hronikā pieminētā pils vecākā vārdu Paike. 
Vairāku Gaujas kreisā krasta vietvārdu - Beku kalns, Bēkurs (divi mājvārdi) un Bēkura tilts - izcelsme jāsaista ar 16.-17. gadsimta Mūrmuižas ìpašniekiem Bukhorstiem.

Tālava pakḷaujas Rīgas bīskapam 1214. gada rudenī (IH, XVIII: 3), tāpēc pirmā Ziemel̦vidzemes (Imera, Tālava, Astigerve u. c.) sadalī̌ana norisinājās laika periodā no 1215. līdz 1216. gadam. Tieši šai laikā tiek nospraustas Rameķa lēņa robežas (terminis Rameke), kuras rakstos piefiksētas daudz vēlāk, tikai 1224. gada Tālavas sadalīšanā (SLVA 79). Būtiska ir Rameķa īpašumu dienvidu puses robeža, kura atdalīja Trikātas novadu no Raunas un Smiltenes. Tā jau ir restaurēta pēc 17. gadsimta pilsnovadu robežām, un Livonijas valstiņu kartē tā iezīmēta kā 16. gadsimta ordeṇa - arhibīskapa robeža (sk. 1., 2. attēlu). Sākotnējā 1214.-1216. gada sadalīšanā Rīgas bīskapa lỉbiešu novadiem tiek pievienots Burtnieku ezera baseins, Imera, Sakala un Rameḳa Gaujas kreisais krasts ar Trikātu. Ordenis dabū Cēsīm un Autīnei piegulošo Tālavas dạ̣u Centrālvidzemes augstienē (Rauna, Dzērbene, Smiltene), kurai Valkas tuvumā bija jāsaiet kopā ar Ugaunijas daḷu. Pirmā Ziemel̦vidzemes sadalīšana labi atspoguḷota Frīdriha Benninghofena pētījumos (Benninghoven 1965, 7. karte; sk. 2. attēlu), kurš par tās norises gaitu norādes ieguvis no 1259. gada priestera Papendorfas Heinriha liecības (Abuls 1924, 45). Hronikā 1216. gada vasarā un rudenī pieminēti tikai pirmie Igaunijas dalīšanas mēǵinājumi (IH, XX: 2; 4), nebilstot ne vārda par Tālavas sadali. Taču Igaunijas dalǐšanu nemaz nebija iespējams uzsākt, netiekot skaidrībā ar tai dienvidos piegulošo latviešu zemju piederību. Apstākḷiem mainoties 1224. gadā, abas daḷas tiek samainītas pretēji, notiek rokāde abpus dabā nospraustajai Rameķa robežai. Beverīnas vārds šai sadalē nekur neparādās, kas liecina par pils atrašanos atstatus no robežām. Savukārt Trikāta 1259. gada liecībā ir pieminēta atseviški, tieši nospraustās robežas tuvumā (Tricatuva; Abuls 1924, 45), un tas vēlreiz izslēdz to no Beverīnas novietojuma saraksta. Hronika 1216. gadā apraksta Beverīnas nodedzināšanu, pēc kuras redzam, ka pils jau ir nonākusi Cēsu ordeņbrāḷu pārzin̄ā (IH, XX: 5). Tā ir būtiska norāde, ka Beverīna 1216.-1224. gada laika posmā ir atradusies zobenbrāḷiem pieškirtajā Tālavas sadaḷā, Vidzemes augstienes ziemeḷu malā. 1224. gadā no Cēsīm uz ziemeḷiem tiek novilkta jauna robeža pa piecām mazām upītēm (Vaidava, Danka, Silupīte, Anuḷa u. c.) līdz Briedei un pa to līdz Burtnieku ezeram. Šeit pieminētais ciems pie Vivas upes (villa apud Viwa; villa Wivan) lokalizējams Cēsu apkārtnē, kur tas varētu būt atradies Tulmenes vakas (Liepas pagasta) teritorijā starp Gauju un Raunas upi. Ordeņa robeža no Burtnieku ezera gāja pa Sedas upi uz augšu un savienojās ar Rameķa robežu Valkas apkārtnē. 1259. gada dokumentā (Abuls 1924, 45) minētais ciems Balaten atradies pie Sedas ietekas ezerā, kur bija vecsaimniecība Baložmuiža, bet ciems Callia identificējams ar vairākām Ķelles mājām Valkas pagastā (igauniski Kelli). Šie trīs ciemi - 
Vivan, Callia un Balaten - izdalīja ordeņa zemju mazapdzīvoto trīsstūri, kuru vēlāk paplašināja uz kaimiņu bīskapijām atṇemto zemju rēḳina, līdz ar ko izveidojās vēstures literatūrā pazīstamais "Gaujas koridors".

Raunas Tanīsa kalnā ir arheolog̣iski pierādīti 12.-13. gadsimta mijas nocietinājumi un apdzīvotība, atklājās fakts, ka šai laikā to mēǵināja nodedzināt, bet daḷa celtṇu palika neskarta un nojaukta tikai pēc ugunsgrēka (Balodis 1928, 33). Arguments, ka Raunas Tanīsa kalnā atradusies Sateklas pils, nebalstās uz uzmanīgu hronikas ziṇu analīzi, jo visas norādes Rusina pili liek meklēt rietumos, starp Siguldu un Cēsīm (Skutāns 2010). Autīne Priekuḷu Sārumkalnā ir acīmredzama, toties Sateklu un Metimni atrast nebūs tik viegli, un šeit nepieciešami jauni arheoloǵiskie izrakumi vismaz trijos pilskalnos. Novietojot Jersikai piederošo Autīnes novadu starp Cēsìm un Raunu - Priekul,os, nav iespējams austrumos no Rauṇa robežupes meklēt arī Sateklu. Tas neatbilst hronikā un dokumentos fiksētajai novadu nonākšanas secībai orden,a varā. Pirmie tiek pievienoti Rusina latvieši, kas, visticamāk, ietilpa līvu novados un pakḷauti ordenim tika jau 1207. gadā (IH, X: 14; XI: 3; XI: 5; XI: 7). Lai arī Autīne atradās tiešā Cēsu tuvumā, Rīgas bīskaps to iegūst pēc Jersikas pakḷaušanas 1209. gadā (IH, XIII: 4; SLVA 38), bet ordenis to main,as ceḷā pārṇem tikai 1213. gadā (IH, XVI: 7; SLVA 56). Tālava ar Beverīnas pili sešus pirmos sadarbības gadus vispār nepieder vāciešiem, ordeṇa pakḷautībā tās trešdaḷa ar Raunas teritoriju nonāk tikai 1214.-1216. gada pirmās sadalīšanas rezultātā. Līdz ar to 1209.-1213. gadā Autīne Vaives krastos kā ķîlis atdalīja ordeni no Raunas novada, un Rūsina novada novietošana šeit nonāk pretrunā ar rakstu dokumentu faktiem. Nekur Vidzemē mēs neatrodam arī vietvārdus, kas būtu cēlušies no vārda sateka, līdz ar ko nenozīmīgā Raunas (arī Raunaisis) un Līčupes sateces vieta augšpus Tanīsa kalna nav nopietni uztverams arguments.

Raunas Tanīsa kalna arheologiskie izrakumi un atsevišksi atradumi pierāda arī viduslaiku perioda, 14.-16. gadsimta intensīvas apdzīvotības pēdas (Balodis 1928, 29-33; Ose, Caune 2004, 377). Populārajā literatūrā sastopamais uzskats par Raunas pils ierīkošanu 1262. gadā izrādās tikai 18. gadsimta hronikas pētnieku patvalīgs pien,ēmums (J. G. Arnts). Dokumentos castro Rownenborgh pirmoreiz pieminēta tikai 1381. gadā (LUB III, 385. sleja), bet apmetne - ville seu palte Rouwnenborch 1471. gadā (LGU I, 428). Viduslaiku apdzīvotība un nocietinājumi konstatēti gan pašā Tanīsa kalnā (Balodis 1928, 29-33; Ose 2004, 380), gan arī pilskalna pakājē - nocietinājumu kontūras - terases un grāvis. Populārajā literatūrā atrodams savāds nostāsts par Raunas pilsētiņas stiepšanos trīs kilometru garumā (Juškevičs 1927, 294), taču tik liela tā nevarēja būt.

Jauns virziens Beverīnas meklējumos ir Baltijas jūras tirdzniecības avotu izpēte, no tiem svarīgākie ir uz 13.-14. gadsimta miju attiecināmie ieraksti Rīgas parādu grāmatā (RS 1872, 1-119). Livonijas pilsētu veido- 


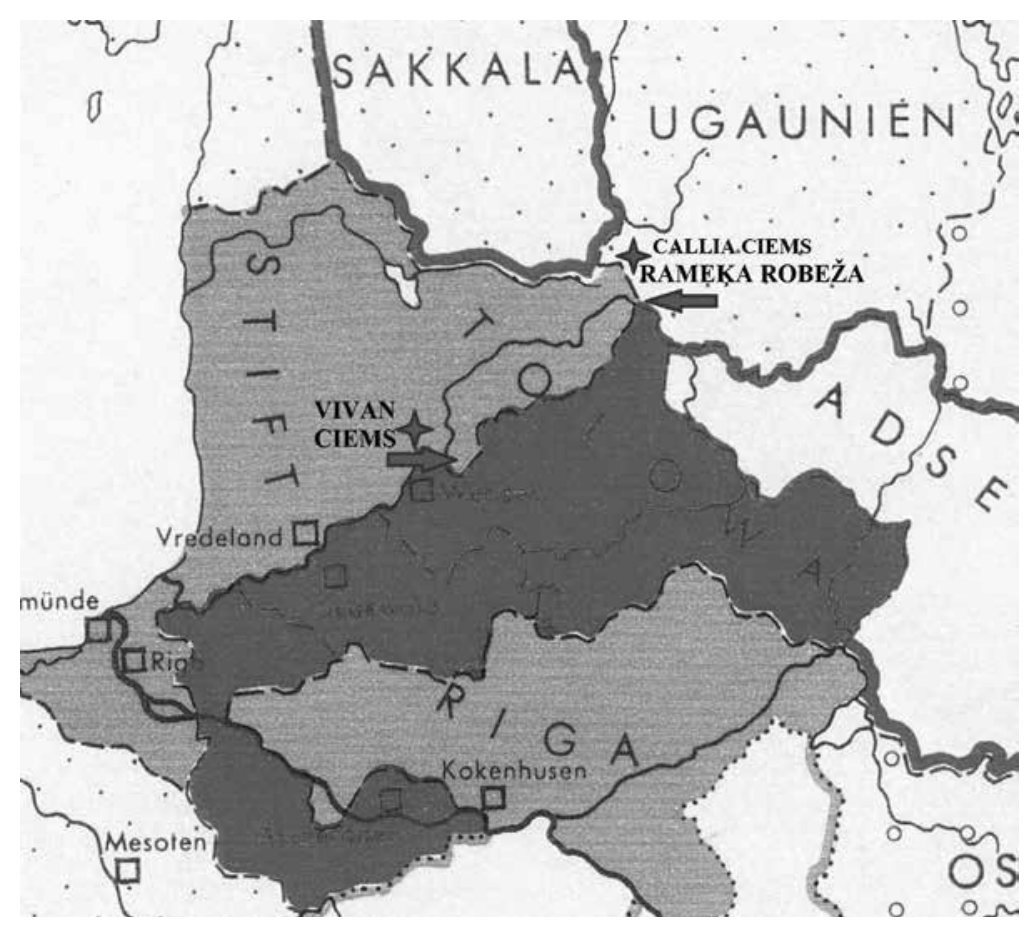

2. attēls. F. Benninghofena sastādītā karte (Benninghoven 1965, 7. karte) par Vidzemes pirmās sadalǐšanas periodu (ap 1216.-1224. gadu). Pelēkā krāsā atzīmēti bīskapa, tumši pelēkā krāsā - ordeṇa īpašumi. Papildināti ar G. Skutāna pieñēmumiem par Rameķa robežas, Vivan un Callia ciemu atrašanās vietām Figure 2. Map compiled by F. Benninghoven (Benninghoven 1965, Map 7) for the period of the first division of Vidzeme (around 1216-1224). The bishop estates are marked in blue, while the order estates - in red. Supplemented with G. Skutāns' inferences about the location of the border of Ramekis, the villages of Vivan and Callia

šanās vēsture ir bijusi aktuāla pētniecības tēma, tāpēc uzmanību piesaista fakts, ka rakstu avotos nav atrodams Raunas pilsapmetnes nosaukums. Gaujas vidustecē tiek pieminētas tādas vietas kā Cēsis, Valmiera, Valka, Straupe un pat Rubene, taču nav ziṇu par Raunu un Trikātu. Parādu grāmatā no Valmieras (de Woldemar) pieminēti sešu personu divdesmit darījumi (RS, 151), bet no Cēsīm (de Wenda) vismaz četrpadsmit personu vairāk nekā četrdesmit ieraksti (RS, 150). Lībekas parādu grāmatā laikā no 1325. gada līdz 1360. gadam uzskaitīti Cēsu pilsētai piederīgu personu četrdesmit darījumu ieraksti un piecdesmit divi galvojumu ieraksti, kamēr Valmiera fiksēta tikai trijos darījumos (Plētiens 2015, 32). Rīgas un Lībekas parādu grāmata norāda uz Cēsu reǵiona vadošo lomu Novgorodas tirdzniecībā 14. gadsimtā. Arī tuvējās Raunas pilsapmetnes tirgotājiem bija jābūt iesaistītiem preču apritē, taču par to ziņas atrast neizdodas. Tāpēc ir 
pamats domāt, ka Raunai tolaik tika izmantots cits nosaukums. Rīgas parādu grāmatā jāpievērš uzmanība piecām personām ar izcelsmes vārdu de Beveren (RS, 124), kuras iesaistītas trīsdesmit astoṇos darijumu ierakstos. Tie ir Dethardus, Andreas, kā arī ar rātskunga titulu apzīmētie Thimmo, brāḷi Iohannes, Heinricus, kuri visi identificējami kā vietējie Livonijas iedzīvotāji. Katrā ierakstā fiksētas arī ar darījumu saistītās personas, starp tiem trīs vidzemnieki - Hermanis un Johans no Valmieras, Lūdolfs no Cēsīm. Taču Vācijas un Livonijas pilsētu (Lībeka, Tallina, Tērbata u. c.) dokumentācijā tirgotāji de Beveren (Bevern, Bevere) tiek pieminēti regulāri - tādi ir raksturīgi visam plašajam lejasvācu dialekta areālam no Holandes līdz Narvai. Vairākumā germāṇu valodu bever nozīmē bebrs, un tas ir bieži sastopams vietvārdos un personvārdos.

Vairākās vietās uz Krievzemes tirdzniecības maršrutiem - Valmierā, Straupē, Raunā un Valkā - pēc 1208.-1224. gada Livonijas izveides parādās nākamo pilsētiņu priekšteces. Tie bija Rīgas tirgotāju veidotie priekšposteñi - atbalsta punkti ceḷā uz Novgorodu un atpakal, sākotnēji nenocietinātas apmetnes. Rauna Livonijas laikmetā kā apdzìvota vieta fiksēta tikai 15. gadsimta beigās, bet tās senākā nosaukuma Beverin nomaiņas iemesls uz Ronneburg ir gaužām vienkāršs. Jāsaprot, ka Rīgas arhibīskapa jaunuzceltajai pilij nosaukums Beverburg ne visai labi piestāvētu. 14. gadsimtā pastāv arī citas bever- tipa vietvārdu un personvārdu saistības ar Raunu, un tādas var vēl atklāties jaunas. Arhibīskapa Fromolda urkundēs Rīgas bīskapijā no 1361. gada septembra līdz 1362. gada jūlijam atzīmēts kāds laicīgās kārtas liecinieks - Teodorihs Beverins (Thidericus Beyeryn; LGU I, 90-92). Šai laikā arhibīskaps dzīvo Vācijā, un kādam vietējam apstākḷu zinātājam bija jādodas pie viņa kā lieciniekam vasaḷu dokumentācijā. Valmiera, Kauguri un Trikāta šai laikā atradās ordeṇa dạ̦ā, bet Rauna pieder Rīgas arhibīskapam. Vēl jāpiemin Bever porten Vecrīgas mūros pie Rīdziñas, mūsdienu Audēju un Kalēju ielas krustojumā (Dambe 1990, 23), kurus 17. gadsimtā nomaina Raunas vārti jau citā vietā, Ģertrūdes un Brīvības ielas krustojumā. Pagaidām Livonijā pieminētās bever- vietas un personas neizdodas nepārprotami saistìt ar Cēsīm vai Raunu, tāpēc nākotnē nepieciešams pētījums par Raunas pilsapmetnes attīstību 13.-15. gadsimta periodā. Ir pamats domāt, ka senākie raunēnieši - pilsētnieki un muižnieki - varētu tikt identificēti arī ar Livonijas dokumentos bieži atrodamajiem personvārdiem Renne, Ronne, Rene u. c. (LGU I, 704; u. c.).

Ieskatoties mūsdienu mežu un purvu masīvu izplatības kartēs, jāsecina, ka teritorija uz ziemeliem no Jumaras un Abula upes 12.-13. gadsimtā bija viens milzīgs mežu un purvu masīvs. To apstiprina arī Igaunijas karagājienu un kauju apraksti hronikā, kur robežu rajonā bieži ir pieminēti meži (IH, XIV: 7; XV: 7). Gaujas vidusteces krastos starp Cēsīm un Valku, kā arī Burtnieka ezera baseinā dzelzs laikmeta pilskalni līdz šim nav konstatēti. 
Ja Kauguros un Trikātā zināmas 12.-13. gadsimta latgaḷu tipa apbedījumu vietas (Beites, Lubu muiža, Kikuts u. c.), Valmieras tuvumā un uz ziemeliem šādu atradumu nav. Lìdz ar to šeit varētu būt pletusies latgaḷu kultūras ziemel̦u perifērija - savdabīgi "mežonīgie ziemel̦i”, kur lauksaimniecībai derīgo zemju apgūšana vēl nemaz nebija sākusies. Gaujas labajā krastā arheologiski nevar fiksēt arī 12.-13. gadsimta nenocietināto apmetnuu pastāvēšanu. Igaunijas karu laikmets 1208.-1224. gadā no šejienes aizbaidīja nomaḷāko viensētu iemītniekus, padarot plašu apvidu uz laiku neapdzīvotu. Lìdz ar to Beverīnas meklējumus varam beigt ar slēdzienu, ka Gaujas krastu mežos senču piḷu pastāvēšanu noraida visvienkāršāko vēsturiskās ǵeogrāfijas un arheologijas datu analīze. Hronika skaidri apraksta pili biezi apdzìvotā zemkopības rajona centrā, kuras iemītnieki kara laikā sapulcējas pilī no tuvējās apkārtnes, šeit pat no viņiem nodevas ievāc Pleskavas krievi.

Beverīnas problēmu radīja pazīstamais skolotājs un novadpētnieks V. Balodis, kurš 19./20. gadsimta mijā popularizēja stāstus par četru senču piḷu atrašanu Valmieras tiešajā tuvumā. Viña dēls F. Balodis to bez ierunām pārñēma un centās pamatot ar arheologijas palīdzību. Viṇa veiktie 1927. gada izrakumi Raunas Tanīsa kalnā izraisīja publisku konfrontāciju ar E. Brastinuu. Tēva un sava prestiža dēl viņš nespēja atteikties no Valmieras hipotēzēm, talkā pieaicināja publicistu J. Juškeviču, kurš izstrādā novadpētnieciska satura rakstu par Raunas vēsturi un novieto šeit Sateklu (Juškevičs 1927, 293). Līdz ar to E. Brastinam zūd iespēja pārliecināt tā laika Latvijas vēsturniekus, bet F. Balodis savu Beverīnu iekḷauj oficiāli akceptētajā Latvijas aizvēstures modelī, kurš līdz šim brīdim nav kritiski pārskatìts. Pēc arheoloǵijas pētījumu ziņām, astoṇās no deviņām būtiskākajām Beverīnas meklējumu vietām neatrodam ne vēlā dzelzs laikmeta nocietinājumus, ne apdzīvotības pēdas, ne arī savrupatradumus. Toties Raunas Tanīsa kalnam atbilst viss hronikā atspoguḷoto pazīmju spektrs, par labu runā arī arheologisko atradumu klāsts. Raunas apvidus vēlā dzelzs laikmetā ir biezi apdzīvots zemkopības rajons (LA, 178), kas atbilst hronikā aprakstītajiem Beverīnas latviešiem un viṇu militārajām aktivitātēm. Pašlaik galvenajam konkurentam - Pekas kalnam - vairāk piestāvētu neliela ordeña koka nocietinājuma loma, bet tā apkārtnes senākie vaku, muižu un ciemu nosaukumi, kā, piemēram, Ūdrene, Volfarte un Voldense, neuzrāda nekādu līdzību ar Beverīnas nosaukumu. Cēsu un Valmieras reǵiona senvietas pēdējos simtpiecdesmit gados ir labi apsekotas, un šeit trūkst ziņu par kādu vēsturei zudušu, nopostītu pilsvietu. Pēc aerolāzera skenēšanas tehnoloǵiju parādīšanās (LIDAR) jaunu pilskalnu atklāšanas iespējamība šajā apvidū vērtējama kā nereāla. Iespējams, ka Beverīnas meklējumus neatgriezeniski varēs beigt tikai jauni izrakumi Pekas kalnā un Trikātas pilsdrupās. Beverīnas problēmu būtu laiks atstāt pagātnei, jo ir vēl daudz aktuālākas tēmas pagātnes mantojuma apzināšanā. 
Šĩs publikācijas saturs nonāk pretrunā ar Beverīnas novada vietējo novadpētnieku un vēstures interesentu gadu desmitos veidotajiem uzskatiem, bet tēze par senču piḷu neesamību šai apvidū liksies pavisam nepievilcīga. Vinuus vajadzētu uzslavēt par centieniem kopt un popularizēt dzimtās puses pagātnes mantojumu un atgādināt, ka no jauna atklātā Valmieras, Mūrmuižas un Trikātas vēsture var izrādīties ne mazāk interesanta un ar savu patiesumu daudzreiz vērtīgāka. Esmu pārliecināts, ka tuvākajā nākotnē iesaistīties pētnieki un entuziasti spēs vēlreiz sanākt kopā uz meklējumus noslēdzošu, labdabīgu domu apmaiņu.

\section{SAĪSINĀJUMI}

IH - Indriķa hronika

EE - Eesti easiajalugu (Igaunijas arheologija)

LA - Latvijas arheologija

LGU - Livländische Güterurkunden, Band I, II

LUB III - Liv-, Est- und Kurländisches Urkundenbuch, Band III

RS - Das Rigische Schuldbuch (Rīgas parādu grāmata)

SLVA - Senās Latvijas vēstures avoti, 1.-2. burtnīca

\section{IZMANTOTIE AVOTI UN LITERATŪRA}

Abuls, P., 1924. Kur atradās Beverīna? Vēsturisks apcerējums. Rīga, 75. Pieejams: https:// dom.lndb.lv [Skatīts 1.05.2021.]

Apals, J., Apala, Z., 1988. Izrakumi Vaidavas pilskalnā un Raunas pilsdrupās. Zinātniskās atskaites sesijas materiāli par arheologiijas un etnogräfijas 1986. un 1987. gada pētijumu rezultātiem: arheologija. Rīga, 16-19.

Auns, M., 1996. Jauna versija par Beverīnu. Latvijas Vēstures Institūta Žurnāls, 3 (20), 109-123.

Ballod, F., 1910. Nekotorye materialy po istorii latyshskogo plemeni s IX po XIII stoletie. Zapiski Moskovskogo Arheologicheskogo instituta. Tom 9. Moskva, 125.

Ballod, F., 1911. Otchet o komandirovke v Pribaltijskij krai letom 1909 goda (Beverinskii raskopki). Trudi Moskovskogo predvaritelnovo komiteta po ustroistvu XV Arheologicheskogo sjezda. Moskva, 26.

Balodis, F., 1928. Tanīsa kalnā izdarītie izrakumi un konstatēto mītnes slāņa kārtu datējums. Archailogiijas raksti, 4. sējums, 1. daḷa. Rīga: Pieminekḷu valde, 19-39.

Benninghoven, F., 1965. Der Orden der Schwertbrüder: fratres milicie Christi de Livonia. Köln: Böhlau Verlag, 525, 16 Karten.

Berga, T., 2018. Valmieras vecpilsētas arheologiija. Rīga: Zinātne, 208.

Brastiņš, E., 1930. Latvijas pilskalni: Vidzeme. 4. daḷa. Rīga, 210.

Brūzis, R., Berga, T., 2020. Arheologiskie pētījumi Valmieras pilsdrupās 2018. gadā. Arheologu pētijumi Latvijā 2018.-2019. gadā. Rīga: NT Klasika, 69-73.

Dambe, V., 1990. Rīgas ielu nosaukumi. Onomastica Lettica. Rīga: Zinātne, 21-32.

Dunsdorfs, E., Spekke, A., 1964. Latvijas vēsture: 1500-1600. Stokholma: Daugava, 797. 
Eesti esiajalugu. 1981. Tallin, 464.

Enzeliņš, H., 1935. Beverīna - Valmierā. Valmierietis, 31. oktobris, 8., 22., 29. novembris.

Enzeliņš, H., 2019. Skati Valmieras pilsētas, draudzes un novada pagātnē. Valmiera: Apvārsnis.

Indrik,a hronika. Ē. Mugurēviča komentāri. Rīga: Zinātne, 1993, 453.

Jemeljanovs, E., 2010. Izrakumi Siguldas Krusta kalnā. Arheologu pētijumi Latvijā 2008.2009. gadā. Rīga, 125-127.

Juškevičs, J., 1927. Rauna. Izglïtibas Ministrijas Mēnešraksts. 10 (94), 285-295.

Kraukle, R., 2016. Arheoloğiskie izrakumi Liepupes pilskalnā 2015. gadā. Arheologu pētijumi Latvijā 2014.-2015. gadā. Rīga: Nordik, 186-188.

Latvijas arheoloǵija. 1974. Rīga, 374.

Lauris, E., 2019. Kur atradās Beverīnas koka pils? Valmierā vai tomēr zem Trikātas mūra pilsdrupām? Beverinas Vēstis. 11 (88), 6. Pieejams: www.beverinasnovads.lv [Skatits 01.05.2021.]

Löwis of Menar, K. v., 1891. Die Deutsch Ordensburg Trikaten in Livland. Sitzungsberichte der Gesellschaft für Geschichte und Altertumskunde zu Riga aus den Jahren 1873-1934. Riga, 37-50.

Livländische Güterurkunden (aus den Jahren 1207 bis 1500), Band 1. Bruiningk, H., Busch, N. (Hrsg.). Riga: H. W. Häcker, 1908, 788.

Livländische Güterurkunden (aus den Jahren 1501 bis 1545), Band 2. Bruiningk, H., Busch, N. (Hrsg.). Riga: H. W. Häcker, 1923, 923.

Liv-, Est- und Kurländisches Urkundenbuch, Band 3. Bunge, F. G. (red.). Reval, 1857, 800.

Lucāns, A., 1996. Diletants meklē Beverīnu. Liesma, 22, 4.

Ose, I., Caune, A., 2004. Latvijas viduslaiku pilis: Latvijas 12. gadsimta beigu - 17. gadsimta vācu piḷu leksikons. 4 sēj. Rīga, 591.

Plētiens, E., 2015. Livonijas mazpilsētas: kas tās bija, un kāda bija to ietekme? Latvijas Vēstures Institūta Žurnāls, 3 (96), 5-44.

Das Rigische Schuldbuch (1286-1352). S.-Petersburg, 1872, 232.

Skutāns, G., 1992. Ceḷ̌š uz Beverīnu? Latvijas Vēsture, 4 (7), 61-67. Pieejams: www. historia.lv [Skatīts 11.02.2021.]

Skutāns, G., 2010. Satekla Ligatnes pilskalnā. Pieejams: www.ligatne.lv [Skatīts 11.02.2021.]

Spekke, A., 1995. Latvieši un Livonija 16. gadsimtā. Rīga: Zinātne, 267. Fragments pieejams: $w w w$.historia.lv [Skatits 01.05.2021.]

Švābe, A., 1933. Die älteste schwedische Landrevision Livlands (1601). Latvijas Universitātes raksti. Tautsaimniecỉbas un tiesỉbu zinātnnu fakultātes sērija. 2. sējums, 3. burtnīca. Rīga, 337-596. Pieejams: https://dom.lndb.lv [Skatīts 01.05.2021.]

Senās Latvijas vēstures avoti. Latvijas vēstures avoti. A. Švābe (red)., 1937. 2. sējums, 1. burtnīca. Rīga: LVI.

Urtāns, J., 1991. Ziemel̦vidzemes pilskalni. Rīga, 70.

Urtāns, J., 1995. Latvijas austrumu daḷas jaunatklātie pilskalni. Rīga, 128.

Vasiḷausks, E., 2014. Žagares II (Žvelgaiču) pilskalns 13.-17. gs.: no koka pils līdz koka muižai. Arheoloğija un etnogrāfija, 28. laidiens. Rīga, 97-108.

Žīgurs, E., 2003. Beverīnas pilsvietas lokalizācijas problemātika. Pieejams: www.historia.lv [Skatīts 11.02.2021.] 


\title{
SOLUTION TO THE PROBLEM OF SEARCH FOR BEVERINNA CASTLE
}

\author{
GINTS SKUTĀNS \\ Mg. hist. \\ E-mail: skutans@inbox.Iv
}

\begin{abstract}
The search for Beverinna Castle, which is referred to in The Livonian Chronicle of Henry (Latin: Heinrici Cronicon Lyvoniae), has spanned over one hundred and fifty years, nevertheless, to date it has not been possible to reach a unified conclusion as to its location. Currently, the research of archaeological excavations and written sources has enabled elimination of the majority of the castle sites in the vicinity of Valmiera, since this locality is entirely devoid of any finds attesting to its population during the $11^{\text {th }}-13^{\text {th }}$ century.

The analysis of the structure of Kauguri Pekas hill and the excavation material, the existence of the fortification can be attributed only to the $14^{\text {th }}-16^{\text {th }}$ century. Thus, the localization of Beverīna can be performed only on the remaining Rauna Tanisa hill, which meets all the criteria recorded in the chronicle. Archaeological studies of the hillfort yield a significant late Iron Age fortification, but the population of the adjacent region is characterized by a dense concentration of archaeological monuments. As no forthcoming publications of historians are expected to continue the search for Beverīna, we can consider this mystery of the past solved.
\end{abstract}

Keywords: Beverīna, hillfort, castle, historical geography, Livonia, Chronicle of Henry, Middle Ages.

\section{SUMMARY}

In Chronicle of Livonia, place name "Beverīna" is mentioned with regard to Talava county fortress (1208-1216) and as the starting point for the campaigns to Estonia. Despite 150 years of searching, historians have not been able to agree on Beverinna's whereabouts. The search encompassed several hillforts and stone masonry castle sites along the River Gauja in the middle of the basin, around the regions of Valmiera and Cēsis. At present, the details of the chronicles and the evidence of archaeological excavations allows to exclude the locations from the list of options one by one. Consequently, problems in search for correct localization were linked to the incompetence and biased approach of the first researchers, as they looked 
for a castle closer to their native land. The documents of $13^{\text {th }}-14^{\text {th }}$ centuries were scarcely used for the record of the research. These documents allow to understand the development and geography of trade in this period. The place mentioned in these sources as Beverina was found to be connected to Rauna and thus could end three centuries of uncertainty. 


\title{
SPREAD OF INFORMATION ABOUT URBAN ELBERFELD SOCIAL CARE SYSTEM IN RIGA (LATE 19 ${ }^{\text {TH }}$ - EARLY 20 ${ }^{\text {TH }}$ CENTURY)
}

\author{
ANASTASIJA SMIRNOVA \\ Mg. hist., historian at the Department of the Riga History Research \\ and Exhibitions at MRHV, acting scientific assistant at the Institute \\ of Literature, Folklore and Art, PhD student at the University \\ of Latvia Faculty of History and Philosophy \\ E-mail: anastasija.smirnova4@gmail.com
}

\begin{abstract}
Paper analyses the principles of poor relief of Elberfeld social care system that spread outside the Prussian Empire and Baltic provinces were among of the first territories of Russian Empire, where those ideas emerged. Urbanised and industrialised Riga was one of the empire's cities where the system was incorporated. It was the first level of developing a future national social care policy in Latvia after 1918. The paper aims to restore the term and achievements of the Elberfeld system known to the social elite before the Soviet occupation when this term disappeared from academic research.
\end{abstract}

Keywords: History of ideas, Elberfeld system, history of social care, social policy, concept of social responsibility, urban industrial area, municipality of Riga.

\section{INTRODUCTION}

Development of social policy in each country was affected by various factors: historical background, political regime, economics, demographical up growth, social relationships between different groups. The so-called social elite, which in this paper is understood as those with exact education, solid financial situation and place in society, spread their ideas on different levels. Therefore, the paper considers one particular system of ideas. The problem explored in the current paper is linked with the History of Ideas or 
Intellectual History, academic school pioneering by American philosopher Arthur Oncken Lovejoy. A. Lovejoy defined the History of Ideas as a discipline, whose research objects are grand, influential, global ideas. He saw human history as a sum of all the knowledge existing in the substantial period, where thinking developed knowledge through emotions, experiences, myths and social behaviour (Plakans 2016, 43; Lovejoy 1940, 11).

This paper aims to provide an analysis of how and which ideas of poor relief from the urban highly-industrialised city Elberfeld of Prussian Empire were incorporated in Baltics through the case of other highly urbanised and industrialised city - Riga, by researching secondary sources, the theory of the system. Therefore, in this paper, expectations about the new social care system will be analysed, as well as its theoretical approach. The research of archive sources will continue after the restrictions due to COVID-19 pandemic are lifted. Minutes of the meetings, decisions of the municipality on the topic discussed here, not used in this paper, will show the actual situation of incorporating and developing the ideas of the Elberfeld system (ES) in Riga. The research will continue by comparing theory - information spread about the ES and the reality, which will allow to find substantiation as to when and how this system was present in Riga. It might seem that implementing a new social care system was a practical activity. However, it is arguable, since the social policy itself developed from ideas and discussions, and it took a long way to bring those ideas into practice and concrete actions to implement the whole system.

Sources. The paper explores the representation of this system in the social thought through the secondary sources - press materials, didactical and scholarly literature written mainly for the educators or those in high administrative positions. The main advantage of those sources against the primary sources is their availability. Those could be re-read in the future so that those sources could have a greater influence on the broader population. On the contrary, the primary archived documents could mostly be used only once and by those involved in the particular discussion. 28 secondary sources are used -15 of them were issued in the territory of present-day Latvia and 13 - in other places of the Russian Empire - Saint Petersburg, Moscow and Kyiv. The sources issued in Latvia are press materials, while the sources issued outside the territory of Latvia are theoretical materials. By the identified authors of those sources, it was possible to establish the information channels through which spread the ideas of ES.

Historiographical insight. The paper will demonstrate the importance of the discussions about the ES in the written materials in the late $19^{\text {th }}$ and the early $20^{\text {th }}$ centuries. It is essential to mention that the theory about the considerable impact of the ES on the development of the future national social policy was well known to the social elite in interwar Latvia. 
A significant example was Latvian lawyer and docent of the social and municipal laws - Pēteris Mucinieks (1899-1980; 1931, 1934, 1935). A crucial argument about the importance of the ES in the development of the national social care policy is that the most comprehensive informative material in the interwar time - Latvian Conversation Encyclopaedia (LKV 1929, 7138-7139) has an entry dedicated to ES. The discussions on the history of the implementation of ES did not take place in the Soviet historiography, possibly made suspect as one of the surpluses of the capitalist policy. The main tendencies in the social history of the Soviet historiography were to analyse it from the worker's perspective. However, "workers" and "the poor" were not the categories that always matched. The task of this paper is also to reintroduce the term of ES in Latvian historiography. In the Baltic states, Lithuania was the first to cooperate in a Western research project about the topic, and, consequently, in the book issued after, ES was mentioned (Hering; Waaldijk 2003). This paper is the first source after the Soviet occupation analysing the Estonian and Latvian cases.

Paper's chronological limits are marked by the beginning of ES in 1870s and the occupation of Latvia in 1940. The method of content analysis of the secondary sources mentioning ES was carried out, thereby examining its possible influence. The original principles of ES in Prussia with its variations incorporated in Riga were compared by using the comparative method.

The paper deals with Riga as an example of poor relief in industrialised urban areas. An article of 1885 analysing poor relief in Riga and comparing it with ES concluded that there were profound poor relief and charity traditions in Riga. Riga realised the most considerable amount of volunteer social work in Russian Empire. Riga statistically was the first among five (Saint-Petersburg, Moscow, Odessa and Warsaw) biggest cities in the empire for the poor relief aid (Düna Zeitung, 241, 1). Riga was the third biggest city in Russian Empire after Saint-Peterburg and Moscow according to its number of industrial workers (Mežgailis 1998), and one of the most important industrial and economic centres, therefore, one of the wealthiest cities in the Russian Empire. The paper will consider the unresearched part of the municipal policy - social care policy. Law of Local Community in 1866, Law of the City in 1877 and Public Welfare Law in 1892 (Leppik 1995, 24-25) composed the legislative core that shaped and developed the administration of Riga city municipality. Those laws stipulated that social care was one of the issues that the municipality of Riga should solve. After complete implementation of the Law of the City in Riga, supervision of the poor was one of the seven commissions of the Board of Riga (Ozolina 1976, $30,38-39,42,57,106,114)$. Riga is an essential case for analysing the development of the ideas of ES, the concept of social responsibility in the municipality and industrial area. 


\section{THE MAIN IDEAS OF ELBERFELD SOCIAL SYSTEM ${ }^{1}$}

The $19^{\text {th }}$ century marked political changes that caused social updates, made this period a synonym of modernity. Serfdom had been gradually abolished, capitalism, nationalism and awakening of ethnic minorities, Marxism emerged. Political competition of empires caused modernisation processes, not only in terms of technological development but also new ideas (Stearns 2012).

Attitude toward the poor changed, and it was essential to improve their life in municipalities. ES was named after a former city of the Prussian Empire - Elberfeld, at present - a city district of Wuppertal in Western Germany. It is one of the pioneering German industrial towns. Its success could be linked with natural benefits - the river and previously also vast fields (Figure 1), and old medieval traditions of corporative society - responsibility for the welfare of its members. Territory of Elberfeld had developed as a textile town since the Middle Ages, and at the end of the $18 \mathrm{t}^{\mathrm{h}}$ century, the social question became topical. The first attempt of a particular poor relief policy pre-dated ES by 100 years with emergence of one of its main principles $-\mathrm{a})^{2}$ decentralisation of poor relief by dividing the city into districts. The first impetus for creating municipal social care was given by the King of Prussia in 1843, when he declared that cities were responsible for the poor. In 1850, even with decentralised social care, the city could not cope with the rising number of the poor. In 1852, banker and Lutheran Daniel von Heydt (1802-1874) created social aid policy known as ES (Gagen 1898, 29-47). A special Poor Relief Committee was established in 1852. The innovation of the ES was the principle that the different districts stratified poor relief with district offices. Poor officers were elected middle- or upper-class citizens who did not receive any salary and could not refuse this position for 3 years; it was considered respectful. Historically, ES belongs to open care, simplifying the funds. That means a necessity for unlimited financial resources. After 1852, social care funds were reduced by $35 \%$ (Fenkel 1899, 29-47.) In the following years, the numbers of poor increased, expenses decreased and the amounts of benefits for those, who really needed them, were raised.

${ }^{1}$ If not mentioned otherwise, all the information in this chapter is acquired from: Derjuzinskij 1908, 454-459, 469, 514; Gogel 1908, 12, 17, 20, 25, 29, 31, 38, 7275, 90-92; Monsteberg 1900, 74-86; Georgievskij 1894, 38, 43-56, 99; LKV 1929, 7138-7139; Warner 1938, 174; Repetitorium (...) 1912, 128-130; Willis 2016.

${ }^{2}$ Letters from "a" to" e" will highlight the main ideas of ES, and the same division will follow in chapter II to analyse the main differences between the original principles of ES with the principles of the same system incorporated by the municipality of Riga. 


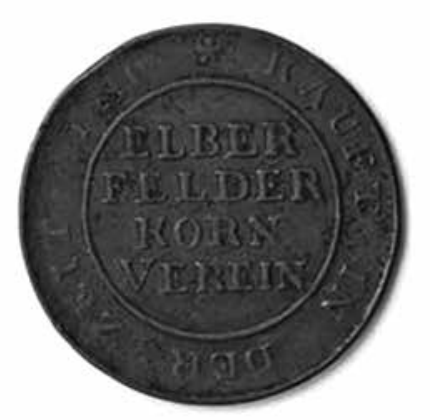

Figure 1. Collection of MHRN, VRVM 64690. Badge of the cereal's union of Elberfeld, 1817

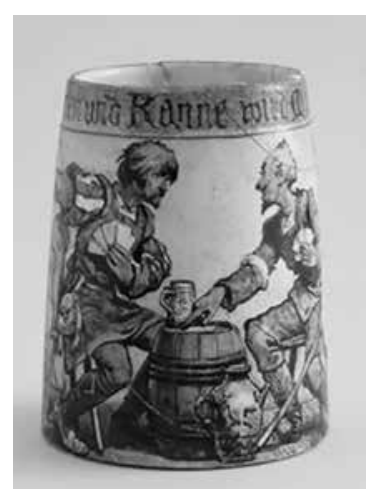

Figure 3. MHRN VRVM 56082 Beer bowl from Berlin, late $19^{\text {th }}$ century, picturing two card-players, observed by wife and children, and the text reads: "With cards and a cup, some man becomes poor"

The main aim of the ES was to find reasons behind poverty; b) individualisation was one of the main principles of ES. Each industrialised city tried to fight with "the army of poor", the attitude for the beggars (it was prohibited), who acquired a name of "professional poor", changed - they could present danger to the wealthiest inhabitants. Therefore, abolishment ideas become popular, and the social elite saw alcohol as a reason some people were poor, and alcoholism itself - as an illness (Figure 3). After the visiting officer had given support to a needy family for 14 days, an officer had to find the solution (find a job, send to the hospital, to educate), aimed at teaching the poor to earn their sustenance. Public works were a temporary solution for reducing unemployment (Gagen 1906, 59, 67, 75). ES was the first approach, where the poor were classified.

Society gradually became secularised, and thereby the role of the churches decreased. ES was based on c) Christian values, it was an indicator of shared social responsibility; the wealthiest citizens were the most responsible for the common welfare of the city. German social politician and layer Emil Münsterberg (1855-1911) wrote that ES was not an entirely new approach; it was rethinking old Christian morality (Münsterberg 1900, 74). Therefore, ES was like a mixture of the first municipality social care system with the principles of volunteering, and the role d) of private organisations increased. The very first social care institutions in Europe used to be churches and church hospitals. The institutionalisation of social care and development of municipal social care system was a way to reform welfare. 
An important role in ES was also taken by e) organisations of women (Frauenverein) (Gogel 1908 12, 17, 20, 25, 29, 31, 38, 72-75, 90-92). Elberfeld municipality subsidised private female societies (K. G. 1900, 8595). ES postulated that women should preferably work from home, assisted by "machines" in producing goods they could sell. Women's society should provide day care for children if it was not possible to work from home or women wanted to work outside the home (Gagen, 41). Elberfeld had high numbers of female workers; men looked after with children. One of the reasons for strikes instigated by Marxism supporters was this role change because of the economic situation (Bazarov, Stepanov 1906, 19, 70, 264, 475).

The ES was widespread even in Portugal (Martins 2003, 177). In the United Kingdom, ES competed with the Poor Law, a social system, which existed for almost four centuries (Warner 1938, 174; Chance 1897, 332-345). In the 1940s, social aid was centralised and professionalised again, but these processes had no chance to influence the Baltic states after the Soviet occupation.

\section{INCORPORATION OF ELBERFELD SYSTEM IN RIGA}

\section{Development of social care in Riga}

The central aspect of possibility to discuss the spreading of ES ideas in Riga are the similar historical backgrounds of Elberfeld and Riga. After 1201, Riga, became a typical European city and its social policy developed from medieval monasteries and hospitals responsible for those in need, into a corporative structure responsible only for its members. The $16^{\text {th }}-18^{\text {th }}$ century shaped the belief that the city was responsible for not only for its members but also for "others" by spreading the Enlightenment ideas. In the $18^{\text {th }}-19^{\text {th }}$ centuries, the belief arose that "those in need" could be dangerous to the social elite, and was shaped in the urbanised and highly industrialised, therefore, wealthiest areas - the cities. Ideas and information of ES spread in Riga successfully also because its popularity reached the zenith precisely when the Russian Empire's City Law of 1870 was attributable to Riga city municipality (1877). Implementation of the City Law in Riga city was slow, which also meant sluggish development of the municipal social policy. Before 1892, the Riga City Council was refused the responsibility of several municipal issues, including social care (Ozolina, 37, 38).

Historian Jānis Bērziňš mentions the term die Armenphledge and correctly connects it with the traditional German poor relief policy and, in his opinion, the same processes, but much slower, took place in Latvia before WWI, however, he does not mention ES (Bērzinšs 2009, 172). ES in 
the territory of contemporary Latvia was introduced mainly in two cities Riga and Liepāja, both (Düna Zeitung, 303, 2) were industrialised, those were also the harbours with the beneficial geographical location. Notably, both cities showed the connection between urbanisation, industrialisation, municipalisation, and the number of those in need, dealt with many poor and beggars (Bērziñš, 162-163). Urban territories in the $19^{\text {th }}$ century were seen as a place of bigger opportunities. They attracted migration - greater salaries, better work conditions, more extensive amounts of social aid, opportunities to study, better medical care. However, at the same time, the workplace was not guaranteed. The city was a place of bigger temptations. Interwar researchers wrote that introduction of the ES in Riga took place in 1886 (LKV 1929, 7138-7139), ten years earlier than in Moscow. The poorest of the city were cared for by the Poor Board (Nabago valde) that replaced its predecessor in poor aid - Poor Curatorial / Directorate (Nabago direkcija / kuratorija) 1802-1886 (Smirnova 2018, 46). However, press analyses of the end of the $19^{\text {th }}$ century do not suggest that the entire educated society of Riga recognised the city as the continuation of the ES, hence, the exact year of introducing ES in Riga is still questionable.

\section{Comprehension of the ideas of ES in Riga}

The first article in the territory of Latvia mentioning ES, was released in 1879 , in the German-language newspaper issued in Riga, predating other parts of the empire. Those were two theoretical articles on how to organise poor relief, considering the example of Germany. Riga was not mentioned there (Rigasche Zeitung, 153, 1; 154, 1). The article of 1884 noted that it would be much more complicated to manage incorporation of ES in Riga, and small cities would be preferable because of the smaller amount of the poor. In addition, it was underlined that Riga in 1884 was not as industrialised as the cities of Germany (Rigasche Zeitung, 250, 1). The article of 1885 analysed the elements of ES existing in Riga, concluding that the finances for poor relief in Riga could be decreased if ES would be fully introduced by monitoring principle of the families of poor and increasing the responsibility of relatives. That could reduce the finances spent on the poor relief in Riga (Düna Zeitung, 241, 1).

The first article where the introduction of ES in Riga was not doubted by the substantial mentioning of the fact that ES principles were established here was released in 1891, containing the analysis of Poor Relief in Saint- Petersburg (Düna Zeitung, 248, 1; Rigasches Kirschenblatt, 6, 4651). The first note of ES in the Latvian language appeared in 1894 when referencing charity organisations in Moscow. In 1895, there was a series of 3 articles in a Latvian magazine, but the introduction of ES in Riga was not mentioned (Dienas Lapa, 95, 1; 96, 1; 97, 1-2, Figure 4). No mentioning 


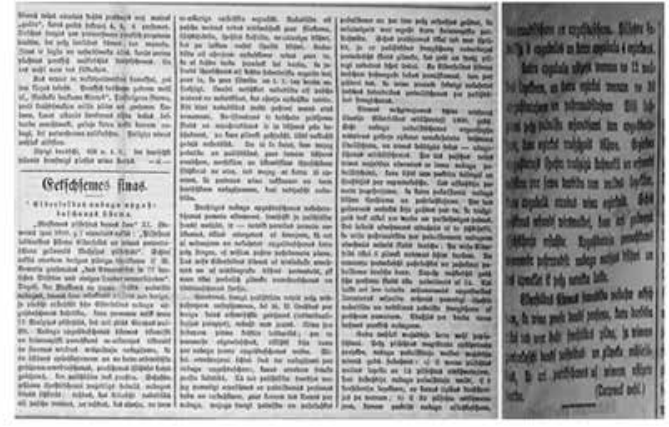

Figure 4. Eekschzemes zinas. Elberfeldas Nabagu apgadaschanas sistema. Dienas Lapa, 1895, 94, 1-2

ES publications were found amongst the Russian-language articles issued in Latvia. The aim of those articles which mentioned ES was to inform about the problems in the municipality of Riga and analyse them. Therefore, unsuccessful elements of ES were not mentioned.

In 1909, it was concluded that social care in Russian Empire was outdated and the church as the only entity responsible for poor relief, while the municipalities only cared for the seriously ill (Rigaesche Kirschenblatt, 45, 536). Only in 1917 the Latvian press announced that the Welfare office (Wohlfahrtsamt) was planning to organise its work on the basis of ES example. It continued the topical idea of 1895 - there were not enough charity workers (Rigasche Zeitung, 3, 2).

The identified authors of the press materials, issued in the territory of Latvia, mainly were German-speaking, foreign social elite. Among them was August Lammers (1831-1892) - a German politician of NationalLiberal political party of Prussian Landtag, a journalist and a researcher, whose article was republished from Preußische Jahrbücher. Speaking about the local elite in the context of ES, the priest of the German Lutheran parish of St. Gertrūde Church Oskar Schabert (1866-1936) must also be mentioned. O. Schabert was influenced by an internship in Germany, after which he implemented social care in his parish in Riga. Analysing theoretical materials issued in other parts of the Russian Empire, it can be concluded that the authors were lawyers and lecturers: Vlodymir Gagen (1874-1930), whose main theoretical topics of interest included poor relief, Vladimir Derjuzhinslij (1861-1920), Sergey Gogel' (1860-1933), lecturer, statistician and economist Pavel Georgievskij (1857-1938). In the period of 1897-1902, there used to be even a unique Charity Journal issued in St. Petersburg by the Central Directorate of Orphanages, Department of Institutions of Empress Mary. In this paper, four articles of this journal were used. On the contrary, 5 articles in Latvian mentioning the ES were mainly from the left-wing Dienas Lapa. Other periodicals represented German press: 4 articles from Düna-Zeitung, knowing its support for 


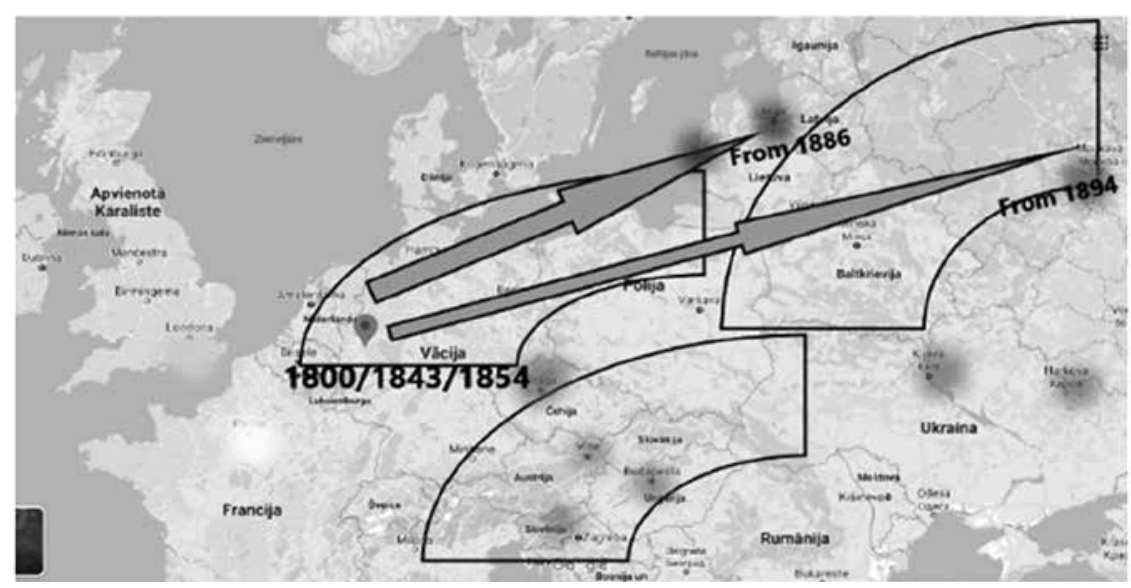

Figure 2. Map. Location of Elberfeld in contemporary Europe and its incorporation in Russian Empire and Riga

Russification, it was not surprising that Riga was not mentioned. 3 were from the opposition - the liberal newspaper Rigasche Zeitung and 2 articles were either from the pastor, or from the religiously oriented newspaper Rigasche Kirschenblatt.

Russian social elite of the $19^{\text {th }}$ century thought that the first introduction of the ES in the empire was not a capital, but the big industrial Moscow (Derjuzinskij, 454-459, 469, 514). In 1894, Guardianship of Moscow City Poor (Gorodskoie popechitesl'stvo bednih) was established and implemented a limited decentralisation of the city, but all the data about the poor was stored in Registration Breau of the Poor. After ES had been implemented in Moscow, some of its principles were introduced in other big cities of the empire - Kharkiv, Kyiv, Vjatka, Stavropol (Gogel 12, 17, 20, 25, 29, 31 38, 72-75, 90-92; Verner, 212-216). However, Moscow and other aforementioned cities were not the first in the Russian Empire, where ideas of ES could be observed (Figure 2).

\section{Elements of ES introduced in Riga ${ }^{3}$}

Further proof that the ES was introduced in Riga much earlier than in other parts of the Russian Empire is found in the history of social care in the city, if it is analysed retrospectively. In interwar times, almost all the elements of ES were maintained in the municipal social work of Riga. Municipal citizens, who were part of the city, dealt with the social issues, while the empire's priorities were administration, police and army (Ulianova

\footnotetext{
${ }^{3}$ Cf. footnote 2.
} 


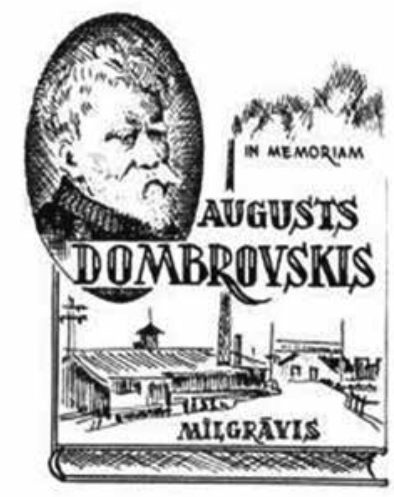

Figure 5. MHRN VRVM 183304, ex libris, 1995-2000. Augusts Dombrovskis with sawmill buildings in Vecmīlgrāvis district of Riga. Author: A. Karlsone

2000, 187-188,197; Katcina 2015, 92-94; Pavlova 2016, 363-376). Social care, medicine, and education expenses were reduced at the beginning of the $20^{\text {th }}$ century (Ozolina, 188), potentially related to ES. In addition, it is essential to mention that the municipality of Riga implemented the oversight of the state-level issue of social care with only the municipality's budget (Ibid). From the $19^{\text {th }}$ century onward, social care was managed by the board of Riga with the financial support of private organisations.

From 1896 to 1940, Riga was divided into the three Poor Board curatoriums a) The division of curatoriums pertained to the River Daugava (Düna Zeitung, 21, 3). Pastor O. Schabert wrote that b) Riga Association Against Begging (Verein Gegen dem Bettel) was a municipal institution and an essential part of poor management, which was more or less linked with ES: "this association is an intellectual child of the civic association". c) He concluded with a reference about outdated legal system regulating the poor aid in the empire, criticised the high level of bureaucracy (Baltische Monatsshift, 1-12, 13-38). In the interwar time, curators examined the actual situation of the poor.

Almost all the big factories of Riga introduced the ideas of ES, and d) Augusts Dombrovskis (1845-1927) was the brightest example of national Latvian awakening and comprehension of community responsibility. A. Dombrovskis was an entrepreneur and an activist of the abolishment community; his "Green School" was free of charge for the poor children of workers (Smirnova 2018, 74, Figure 5). The development of the national humanitarian institutions in independent Latvia was dedicated to voluntary organisations both on state and municipal level (Kattcina, 92-94). Hebrew social care mainly was realised by organisations, because municipalities provided aid only to registered citizens of the city. Confessional and ethnic aspects were the main stratification factors of social care institutions, and such division remained operational also in the interwar period (Smirnova, 67). 
The importance of female e) activities in social care in Riga would be an exemplary subject of a separate paper, but it is essential to say that this was one of the first elements introduced from ES (Ibid, 30-33). In the $19^{\text {th }}$ century, the bishop of Lithuania recognised ES as the best approach and remarked that women were especially suitable for the role of welfare workers (Praspaliauskiene 2003, 171-172; Marcinkieviciene 2003, 6569). Even in the interwar time, $90 \%$ of Lithuanian volunteer organisations were either of the church, or consisted of female organisations. In case of Latvia, female civic organisations were the most active. One of the earliest examples in Riga was Ladies' Group of 30 persons (Dāmu pulciņs), which since 1879 practised placement of orphans and foundlings in trustworthy families for some monetary remuneration. In addition, many charity organisations in Riga had female groups. For example, Katrīna Mengele established an orphanage of a Latvian charity organisation in 1897 (Smirnova, $30,74)$.

\section{CONCLUSIONS}

In the $19^{\text {th }}$ century, the entire Europe was trying to develop the most modern system of poverty relief, understanding the social responsibility and establishing the administration of municipalities. The discussions about the poor relief were a part of the History of Ideas, and ES was a part of the welfare state's history. ES appeared in Baltic states sooner than in other territories of the empire, similarly to the other modernisation elements - abolishment of serfdom, a higher level of literacy. Baltic provinces were multi-ethnic; new ideas were incorporated from both the West and East much faster. Introduction of the ES was linked with Baltic Germans, who formed the local social elite - primary the officers of administrative law or educators. Latvians had just started to create charity organisations. Therefore, they do not realise the incorporation of ES in Riga. Successful implementation of the ES was connected with the development of the city law, the municipal responsibility toward those in need. Moscow and other aforementioned cities realised ES principles more completely, practically. Introduction of ES meant incorporating and accepting the European model of poor relief. The analysis showed that the main theoretical channel for ES ideas was the liberal wing, mostly connected with the German-speaking world. The more expansive Russian Empire, with the growth of concrete academic centres, universities, served as a better soil for local theoreticians of social care policy and provided an opportunity to release the theoretical academic literature. 


\section{ABBREVIATIONS}

ES - Elberfeld System

MRHN - Museum of the History of Riga and Navigation

\section{SOURCES AND LITERATURE}

\section{SOURCES}

A. S. Biobibliografia. F. Derjuzhinskij. Zametki ob obschestvennom prizrenii. Moskva. Izdanie Grosman i Kpebel'. Vestnik blagotvoritel'nosti, 1898, 6, 57-60.

Bazarov, V., Stepanov, T., 1906. Ocherki po istorii Germanii v XIX veke. 1 tom. S-Peterburg.

Chance, W. The Elberfeld and English Poor Law Systems: A Comparison. The Economic Journal, 1897, 7 (27), 332-345.

Derjuzhinskij, V. F., 1908. Politseiskoje pravo. Posobie dlja studentov. S-Peterburg: Senatovaia tipografia.

Dr. Eg. St. Die ständige Stadtgemeinde in der Vergangenheit, Gegenwart und Zukunft. Düna Zeitung, 1908, 303, 2.

Dr. St. Das Armenwesen der Stadt Riga.* Düna Zeitung, 1895, 241, 1.

Fenkel', V. Zadachi blagotvoritel'nosti v Rossii. Vvedeniie. Vestnik Blagotvoritel'nosti, 1899, 3, 29-47.

Gagen, V. Organizacia ukazania raboti. Vestnik blagotvoritel'nosti, 1898, 5, 39-51.

Gagen, V. Perevod s nemetskogo. 1906. Kak ustraivajutsja gorodskije obschetstvennije raboti. Opit netmetskih gorodov. S-Peterburg: Gosudarstvennaja tipografia.

Georgievskij, P. I., 1894. Prizrenie bednih i blagotvoritel'nostj. S-Peterburg.

Gogel', S. K., 1908. Objedineniie i vzaimodeistviie chastnoi i oschestvennoi blagotvoritel'nosti. S-Peterburg: Obschestnennaia pol'za.

K. G. Literturnoie obozrenie. Vestnik Blagotvoritel'nosti, 1900, 11, 88-95.

Lammers, A. Fortschritte in praktischer Armenphledge. Rigasche Zeitung, 1879, 153, 1; 1879, 154, 1.

Monstenberg, E. 1900. Prizrenie bednih. Rukovodstvo k prakticheskoj deiatel'nosti v oblasti popechenia bednih. S-Peterburg.

Repetitorium po pol'icejskomu pravu, 1912. Kiev.

Schabert, O. Das Armenwesen der Stadt Riga aus Grund der historisch-statistischen Studie von Aleks. Tobien. Baltische Monatsshift, 1897, 1-12, 13-38.

Verner, I. A., 1913. Sovremennoie hoziastvo goroda Moskvi. Moskva: Gorodskaia tipografia.

Warner, A. G., 1938. American Charities. A study in Philantrophy and Economics. New York: Thomas V. Crowell, \& Company Publishers.

Das Armenwesen in Livland. Rigasche Zeitung, 1884, 250, 1.

Über die Armenpflege Petersburgs. Düna Zeitung, 1891, 248, 1.

Par darbu nemeem Kreewijā. Dienas Lapa, 1895, 205, 1.

Eekschzemes ziñas. Elberfeldas Nabagu apgadaschanas sistema. Dienas Lapa, 1895, 94 , $1-2 ; 1895,95,1 ; 1895,96,1 ; 1895,97,1-2$.

Locales. Der Gerein gegen den Bettel. Düna Zeitung, 1896, 21, 3.

Bericht über die Gemeindes Diakonie in der Dom-Gemeinde zu Riga im Jahre 1899. Rigasches Kirschenblatt, 1900, 6, 46-51.

Vorträge über die Armenpflege. Rigasche Kirschenblatt, 1906, 45, 536.

Lokales. Werberuf. Rigasche Zeitung. 1917, 3, 2. 


\section{LITERATURE}

Bērziņš, J., 2009. Latvijas rūpniecības strādnieku sociālais portrets 1900-1914. Rīga: Latvijas vēstures institūta apgāds, 335.

Katcina, T., 2015. El'berfel'dskaia sistema kak obrazec sotsialnoi politiki na komunalnom urovne vo vtoroi polovine XIX veka. Gramota, 92-94.

Lepikk, L., 1995. Historical Roots of Social Welfare Policy in Estonia. Simpura, S., (ed.) Social Policy in Transition Societies. Helsinki: The Finnish Federation for Social Welfare, 23-30.

Latviešu Konversācijas vārdnica, 1929. IV sēj. A. Švābe, A. Būmanis, K. Dišlers, (red.) Rīga: A. Gulbja apgādībā, 7138-7139. sl.

Lovejoy, A., 1940. Reflections on the History of Ideas. Journal of the History of Ideas, 1, 3-23.

Marcinkieviciene, D., 2003. Daniele Petkevicaite-Bite and Social Work of Women in Lithuania at the End of $19^{\text {th }}$ and the Beginning of the $20^{\text {th }}$ Century. Hering, S., Waaldijk, B., eds. History of Social Work in Europe (1900-1960). Female Pioneers and their Influence on the Development of International Social Organisations. Opladen: Leske + Budrich, 65-69.

Martins, A., 2003. Women in the History of Social Work in Portugal. Hering, S. [..], 173-177.

Mežgailis, B. Mēs viena gadsimta četrās paaudzēs pie Baltijas jūras. Latvijas Vēstnesis, 12.03.1998., Nr. 66.

Mucinieks, P., Sociālā likumdošana, pēc lekcijām lasītām Latvijas Ūniversitātē. Augstskola Mājā. 1931. Nr. 26-51.

Mucinieks, P., 1934. Rokas grāmata sociālās apgādes darbiniekiem. Rīga: Latvijas pilsētu savienības izdevums.

Mucinieks, P., 1935. Sociālā likumdošana, 2. $d$.

Organisation of Social Welfare. Available at: https://www.historyofsocialsecurity.ch/ institutions/cantonal-local-and-private institutions/organisation-of-social-welfare [accessed: 20.11.2020.]

Ozoliṇa, Dz., 1976. Rìgas pilsētas tēvi un vinu komunālā politika (1877-1913). Rīga: Zinātne, 284.

Pavlova, I., 2016. Elberfel'dskaia sistema sotsial'noj pomoschi neimuschim: ot dobrovol'chestva k professionalizmu. Zhurnal issledovanij socialnoj politiki, 14 (3), 363-376.

Plakans, A., 2014. Rietumu un latviešu historiogrāfisko saikṇu mijiedarbes veidošanās un attīstība kopš 1991.gada: dažas piezīmes. I. Feldmanis, J. Taurēns (zin. red.) Latvijas vēsture krustcelēs un jaunu pieeju meklējumos. Rīga: LU Akadēmiskais apgāds, 43-50.

Praspaliauskiene, R., 2003. Charity organizations in Lithuania in 1900-1950. Hering, S. [..], 171-172.

Smirnova, A., 2018. Bērnu sociālā aprūpe un Rïgas pilsētas bērnu patversmes 20. gs. 20. gados - 1934. gadam: Juglas bērnu patversmes piemērs. Mağistra darbs. Rìga: LU VFF. Darba zinātniskais vadītājs - prof., Dr. hist. Ēriks Jēkabsons.

Stearns, P. N., 2012. Rethinking the long 19-th century in world history: Assessments and alternatives. World history connected, Urbana 9 (3).

Ulianova, G., 2000. Blagotvoritel'nostj i obscestvennoie prizreniie v Rossiji XIX - nachala $\mathrm{XX}$ veka. Institutsional'noie razvitiie $\mathrm{v}$ kontekste formirovaniia grazhdanskogo obschestva. Trudi instituta rossijskoj istorii RAN 1997-1998, 2, 164-217.

Willis, J., 2016. The Elberfeld system: poor relief and the fluidity of German identity in midnineteenth century Germany. Master's thesis. Boise State University. 


\title{
INFORMĀCIJAS IZPLATĪŠANĀS PAR ELBERFELDES URBĀNO SOCIĀLĀS APRŪPES SISTËMU RĪGĀ (19. GADSIMTA BEIGAS - 20. GADSIMTA SĀKUMS)
}

\author{
ANASTASIJA SMIRNOVA \\ Mg. hist., Rīgas vēstures un kuġniecības muzeja Rīgas vēstures izpētes \\ un ekspozīciju darba nodaḷas vēsturniece, Latvijas Universitātes \\ Literatūras, folkloras un mākslas institūta zinātniskā asistenta p. i., \\ Latvijas Universitātes Vēstures un filozofijas fakultātes doktorante \\ E-pasts: anastasija.smirnova4@gmail.com
}

ANOTĀCIJA

Rakstā tiek analizēti vācu Elberfeldes sociālās sistēmas (ESS) nabadzīgo aprūpes principi, kuri izplatījās ārpus Prūsijas impērijas robežām, - Baltijas provinces bija Krievijas impērijas teritorijas, kur šīs idejas parādijāas visātrāk. Urbānā un industrializētā Rīga bija viena no impērijas pilsētām, kurā tika ieviesta šì sistēma un kas bija viens no soḷiem turpmākās nacionālās sociālās aprūpes sistēmas izveidošanā Latvijā pēc 1918. gada. Raksta uzdevums ir atjaunot un aktualizēt Elberfeldes sistēmas jēdzienu un tās sasniegumus, kas bija aizmirsti un netika pētīti pēc padomju okupācijas, kaut gan bija labi pazīstami 19. gadsimta un starpkaru posma izglītotajai sabiedrībai.

Atslēgas vārdi: ideju vēsture, Elberfeldes sistēma, sociālās aprūpes vēsture, sociālā politika, sociālās atbildības izpratne, industriāli urbānā vide, Rīgas pašvaldība.

\section{KOPSAVILKUMS}

Elberfeldes pilsēta ir slavena ne tikai ar to, ka tā bija viena no pirmajām Prūsijas impērijas industrializētajām pilsētām, bet arī ar to, ka tajā tika izstrādāta sociālās aprūpes reforma, kas pazistama kā ESS. Baṇķieris Daniels fon Heits attīstīja šo ideju pēc tam, kad Prūsijas karalis 1843. gadā pasludināja, ka pilsētas ir atbildīgas par to trūcīgajiem iedzīvotājiem. Galvenie ESS principi bija: 1) decentralizācija, veidojot speciālus birojus; 2) individualizācija, kur trūcīgo kontrolierim bija jānoskaidro trūkuma iemesli un bija jāizdomā veids, kā palīdzēt ǵimenei pārvarēt trūkumu; 3) ESS realizētāji bija vidējās un augstākās klases turīgie pārstāvji, kas nozīmēja arī 
sabiedrības iesaisti, sociālās atbildības apziṇu; 4) ES balstījās uz kristīgajām vērtībām sekularizētājā pasaulē, bet mainījās attieksme pret ubagotājiem kā pret "profesionālajiem trūcīgajiem"; 5) īpaša loma ES - sievietes iesaiste brīvprātīgajā darbā.

ESS Latvijas teritorijā jāsaista ar ostas pilsētām Rīgu un Liepāju. Tiek uzskatīts, ka ESS Rīgā ienāca daudz ātrāk nekā pārējā Krievijas impērijas teritorijā. Tomēr joprojām nav zināms konkrēts gads, kuru var uzskatīt par ESS ieviešanu Rīgā. ESS ideju ienākšana jāsaista ar administrācijas amatos nodarbinātajiem vācbaltiešiem, kuri arī apzinājās, ka ESS ir inkorporēta Rīgā. Latvieši, kuriem tikai sāka veidoties labdarības organizācijas, neapzinājās par ESS idejām Rīgā. Tomēr praktisko ESS ieviešanu traucēja Krievijas impērijas birokrātija, tādēḷ Rīgā ienāca pirmie ESS iedīgḷi, bet praktiskāka ES realizācija notika vēlāk. Galvenais ES ideju kanāls bija cieši saistīts ar vāciski runājošām zemēm, tāpēc Baltijā šīs idejas parādījās agrāk, bet noteikta akadēmiskā vide un universitātes citās Krievijas impērijas pilsētās l,āva šīs idejas ātrāk tur izpildìt. 


\title{
SAREŽC̣ITTAIS PAGĀTNES MANTOJUMS LATVIJĀ: IESKATS OTRĀ PASAULES KARA PIEMIṆAS VIETĀS RĒZEKNĒ (1945-1991)*
}

\author{
KASPARS STRODS \\ MA arhīvniecībā, Latvijas Universitātes Filozofijas un socioloğijas \\ institūta pētnieks, Latgales Kultūrvēstures muzeja vēsturnieks \\ E-pasts: kaspars.strods88@inbox.IV
}

\begin{abstract}
ANOTĀCIJA
Otrais pasaules karš kḷuva par lielāko militāro konfliktu cilvēces vēsturē. Tas prasīja desmitiem miljonu cilvēku dzīvību un atstāja paliekošas sekas līdz mūsdienām. Lai gan ir pagājuši vairāk nekā 70 gadi kopš kara beigām, par tā laika trağiskajiem notikumiem Latvijas teritorijā šodien mums atgādina vairāki simti piemiṇas vietu (pieminek|̣i ${ }^{1}$, memoriāli² u. c.). Arī Rēzeknē laika gaitā ir izveidotas vairākas piemiṇas vietas, kuras veltītas gan Padomju Savienības, gan nacistiskās Vācijas totalitāro režīmu upuru piemiṇai. Publikācijas mērḳis ir sniegt ieskatu konkrēto piemiṇas vietu izveidē, to vēsturiskajā attīstības procesā, kā arī nozīmi mūsdienās.
\end{abstract}

Atslēgas vārdi: piemiṇas vietas, Otrais pasaules karš, Padomju Savienība, nacistiskā Vācija, Rēzekne.

\section{IEVADS}

Jebkurš militārs konflikts atstāj postošu ietekmi uz miljoniem cilvēku dzīvi. Šajā ziṇā Otrais pasaules karš pārspēja visus līdz tam cilvēcei zināmos militāros konfliktus, jo tas "bija "totālais karš", kurā Eiropas

* Šis raksts ir sagatavots Latvijas Zinātnes padomes finansētā projektā (Nr. lzp2019/1-0241) "Sarežgiîtais vēsturiskais mantojums Latvijā: holokausta tūrisma vietas starp piemiņas kultūru, mūsdienu tūrisma pieprasījumu un piedāvājumu”. 
civiliedzīvotāji piedzīvoja okupāciju, represiju un iznīcināšanas šausmas" (Zellis 2011, 173).

Karš atstāj ilgstošu ietekmi uz daudzu cilvēku apziņu. Savā ziņā kara zaudējumus iemieso arī neskaitāmie monumenti un piemiņas vietas, kurās atspoguḷojas konkrēto notikumu radītās traumas un valdošie pēckara atmiņu naratīvi. Totalitārajos režīmos šie naratīvi ir cieši saistīti ar šo varas pārstāvju ideolog̣iskajiem priekšstatiem. Īpaši tas attiecas uz pēckara okupēto Latvijas un daudzu citu Austrumeiropas valstu teritoriju, kad neskaitāmos padomju režīma pieminekḷos atspoguḷojās "jaunās impērijas" militārie sasniegumi, kā arī totalitārās un ideolog̣iskās vērtības, un "daudzas sabiedrības sevi maldina, ka šìs vērtības ir mūžĩgas" (Lowe 2020, XVII).

Tas atspogulojās arī Latvijas neatkarības atjaunošanas procesā, kurā iezīmējās krasa attieksmes maiņa pret padomju vēsturisko mantojumu, tostarp pieminekḷiem. Daudziem šie padomju monumenti saistijās ar ilgstošu pagātnes traumatisko okupācijas pieredzi, bet citiem gluži otrādi pagātnes sasniegumiem. Var piekrist apgalvojumam: "Mēs iemūžinām šīs vērtības akmenī un liekam tās uz podesta, bet, kad pasaule mainās, tad mūsu pieminekḷi un vērtības, kurus tie reprezentē, ir iesaluši laikā" (Lowe 2020, XVII).

Lìdz šim Latvijas historiogrāfijā saistībā ar dažādām Otrā pasaules kara piemiñas vietām ir veikti atsevišķi pētijjumi ${ }^{3}$, tomēr tie pamatā aptvēruši valstisko līmeni, bet reǵionālais aspekts tikpat kā nav nonācis vēsturnieku izpētes redzeslokā. Izṇēmums ir holokausta piemiņas vietas. Šeit jāizcel̦ Meijera Melera apjomīgais darbs "Latvijas ebreju kopienas vēsture un holokausta pieminas vietas" u. c. ${ }^{4}$ Tāpat ir veikti pētijumi par atsevišķām holokausta piemiņas vietām vairākos Latvijas reǵionos (piemēram, Rēzeknē̄ ${ }^{5}$ u. c.). Tomēr plašākā mērogā Otrā pasaules kara piemiņas vietas līdz šim nav skatītas, un detalizētākas informācijas par tām nereti trūkst. Jāpiebilst, ka samērā plaši ir pētīta 8. un 9. maija piemiņas kultūra un ar to saistītie jautājumi ${ }^{6}$, kā arī padomju deportācijas ${ }^{7}$ u. c. komemorācijas procesi.

Raksta mērķis ir sniegt ieskatu Otrā pasaules kara notikumiem veltīto piemiṇas vietu izveidē Rēzeknē, to vēsturiskajā attīstîbas procesā, kā arī nozīmi mūsdienās. Publikācijas sagatavošanā kā avoti galvenokārt izmantoti dažādi padomju okupācijas un Latvijas neatkarības periodu preses izdevumi ("Ausma", "Znamja Truda", "Darba Karogs" "Rēzeknes Vēstnesis" u. c.), kā arī Latgales Kultūrvēstures muzeja krājuma, Latvijas Nacionālā arhìva u. c. materiāli. Šie avoti ḷauj apzināt vairāku piemiņas vietu izveides vēsturiskos aspektus, kā arī labāk izprast to nozīmi mūsdienās. 


\section{NACISTU OKUPĀCIJAS REŽİMA UPURU PIEMIṆAS VIETAS}

Viena no apjomīgākajām piemiņas vietām, kura saistās ar nacistu okupācijas laiku Rēzeknē, ir bojāgājušajiem padomju karagūstekṇiem veltītais memoriāls. Šajā vietā 1941.-1944. gadā atradās karagūstekṇu nometne "Stalag 347" (citos avotos saukta arī par "Stalag 340"). Pēc dažādām aplēsēm, nometnes darbības laikā (pamatā no bada, slimībām, ievainojumiem, cietsirdīgas izturēšanās, kā arī nošaušanas) bojā gāja aptuveni 20000 cilvēku (Nikonov 2018, 434-435; Strods 2020a). Jāatzīmē, ka padomju avotos bojāgājušo skaits tiek lēsts ap 30 līdz 35 tūkstošiem (Nikonov 2018, 435), kas acīmredzami ir pārspīlēts skaitlis.

Pēc Otrā pasaules kara šajā teritorijā padomju varas iestādes ierīkoja vācu karagūstekņu nometni. Tajā ieslodzītie karavīri tika iesaistīti dažādos pilsētas labiekārtošanas darbos. 20. gs. 60.-70. gados notika šīs teritorijas industrializācijas process, kā rezultātā tika iznīcināta vācu karagūstekṇu nometnes teritorijā izveidotā karavīru kapsēta (Nikonov 2018, 443-444; Strods 2020a). Pirmais piemineklis nometnes teritorijā uzstādīts 1959. gada 4. novembrī, savukārt 1974. gada jūlijā (par godu Rēzeknes 30. "atbrīvošanas" gadadienai) izveidots memoriāls (Strods 2020a). 2019. gadā tika uzsākts Ziemeḷu rajona parka teritorijas atjaunošanas un labiekārtošanas projekts, kura rezultātā paredzēts atjaunot arī padomju karagūstekṇu memoriāla apkārtni.

Vēl viena nacistu upuriem veltītā piemiņas vieta atrodas blakus Rēzeknes tirgus laukumam, kur pēc nacistiskā režīma varas iestāžu rīkojuma 1942. gada 4. janvārī notika 30 Audriņu ciema iedzīvotāju (vīriešu) publiska nošaušanas paraugakcija, savukārt pārējie (apmēram 200) ciema iedzīvotāji iepriekšējā dienā (3. janvārī) tika nogalināti Ančupānu kalnos (Malahovskis 2019, 100). Godinot bojāgājušos, 1965. gada 21. jūlijā šajā vietā atklāja simbolisku piemiņas plāksni (Pie fašisma upuru sienas 1965, 87, 1), savukārt 1990. gada 4. janvārī izveidoja jaunu piemiņas plāksni ar 30 nošauto cilvēku vārdiem (Nizinska 1990, 3, 1), kura pēdējo gadu laikā vairākkārt ir atjaunota. Šajā vietā periodiski norisinās dažādi Otrā pasaules kara atcerei veltītie piemiņas pasākumi, tostarp 4. janvārī, 8. un 9. maijā.

Lìdzīgi kā daudzās citās Latvijas pilsētās, arī Rēzeknē starpkaru periodā ievērojamu sabiedrības daḷu veidoja ebreji. Pēc 1935. gada Tautas skaitīšanas datiem, ebreji veidoja 25,43 \% jeb 3342 no visu iedzīvotāju kopskaita (Salnītis 1936, 297). Lielākā daḷa no viṇiem gāja bojā nacistu, kā arī to atbalstītāju īstenotā holokausta laikā. Pēc kara, godinot šo traǵisko notikumu upurus, tika izveidotas vairākas piemiņas vietas. Par vienu no Rēzeknes ebreju iznīcināšanas vietām kḷuva vietējās ebreju kapsētas teritorija. Šeit pagājušā gadsimta 40. gadu otrajā pusē, kā arī 80. gados uzstādīja divus 
pieminekḷus. Viens atrodas masu iznīcināšanas vietā, savukārt otrs - netālu no kapsētas ieejas (Strods 2017, 78). Jaunākais bojājumu dēḷ 1990. gadā tika atjaunots (Bruzgule 1990, 140, 3). Zīmīgi, ka šajos pieminekḷos, tāpat kā daudzos citos attiecīgā laika šāda veida objektos, atspogul,ojas padomju periodam raksturīgā iezīme - uz tiem netiek norādīta bojāgājušo cilvēku tautība, bet gan apzīmējums "fašisma upuri". Šāds vārdu salikums ir gan uz pieminekḷa Rēzeknes ebreju kapsētā, gan Vipingas mežā (Magone 1989, 90, 1). Tas ir izskaidrojams ar PSRS piekopto “" padomju pilsonu”" "politiku"”. Respektīvi, šādā veidā padomju vara centās neizcelt holokausta upurus, lai pēc pastāvošās ideologíijas priekšstatiem "nesašḳeltu padomju l,aužu kopumu" (Bērziņš 2015, 288).

Vēl viens padomju režìma beigu perioda piemineklis, kurš veltīts nacistiskā režīma upuriem (tostarp nogalinātajiem ebrejiem), 1989. $\operatorname{gada} \bar{a}^{8}$ (atjaunots 2000. gadā) izveidots Vipingas meža teritorijā netālu no bijušā Rēzeknes tuberkulozes dispansera. Pēc pieejamās informācijas, šeit 1943. gada pavasarī (uz pieminekḷa norādīts 6. marts) nogalināti 34 ebreji (tostarp padomju aktīvisti) (Magone 1989, 90, 1; Melers 2013, 267; Strods 2017, 79). Jāpiebilst, ka pēckara padomju varas iestāžu izmeklēšanas dokumentos norādīts, ka Vipingā nogalināti arī padomju karagūstekņi, politieslodzītie u. c. personas (Nikonov 2018, 451).

Pēdējā laikā šĩ piemiṇas vieta ieguvusi arī visnotal, pretrunīgu slavu. 2020. gada 9. maijā pēc Latvijas-Krievijas kultūras un ekonomikas

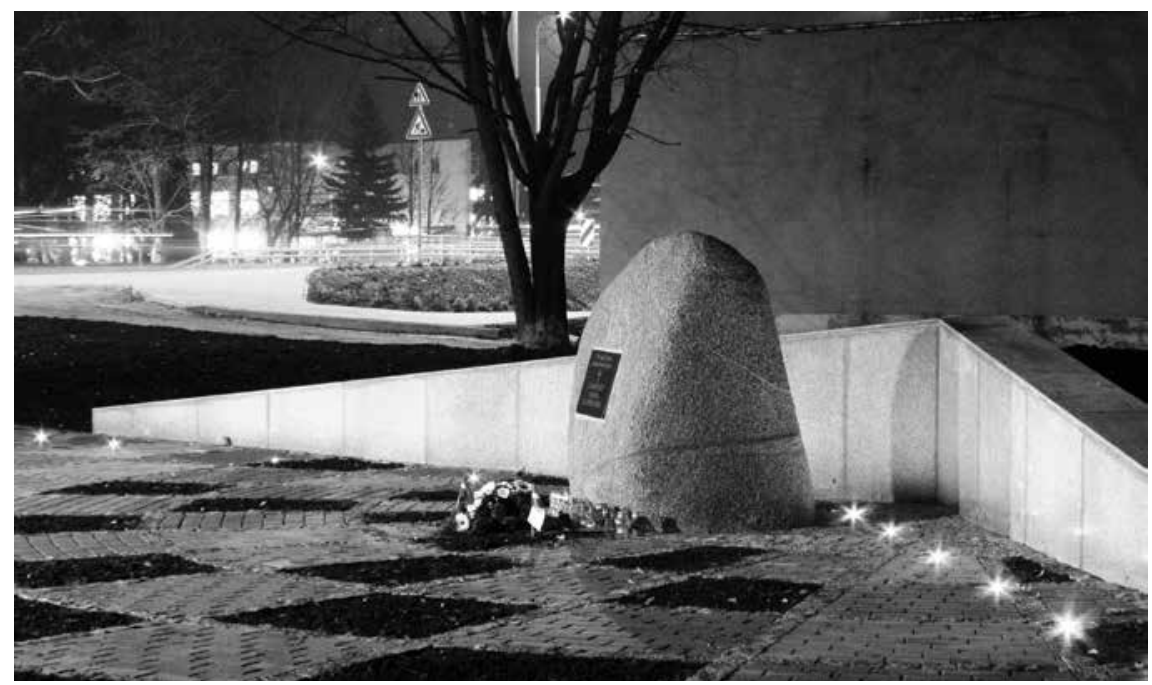

1. attēls. Pieminas akmens 1941. gada jūnija-jūlija padomju represiju upuriem. Foto: A. Bondarenko

Figure 1. Memorial stone to the victims of Soviet repressions of June-July 1941. Photo: A. Bondarenko 
sadarbības biedrības "Slavia" iniciatīvas pieminekḷa apkārtnē uzsāka veidot t. s. Piemiņas un Uzvaras aleju par godu Uzvaras dienas 75. gadskārtai (Nagle 2020). Šo ieceri atbalstīja arī vietējā pilsētas pašvaldība (Gilis 2020, 36, 1; Nagle 2020). Šĩ iniciatīva tika turpināta tā paša gada oktobrī, kad “jaunajā alejā" papildus iestādīja 75 bērzus (Utāns 2020, 87, 2). Šādas aktivitātes liek domāt par vēlmi mākslīgi radīt jaunas pieminas vietas, kuras ietver padomju vēstures ideolog̣iskā motīva - Sarkanās armijas kā "atbrīvotājas tēla" - stiprināšanu.

\section{PADOMJU KARAVĪRIEM VELTĪTĀS PIEMIṆAS VIETAS}

Atbilstoši padomju varas perioda ideoloǵiskajām tradīcijām tieši Sarkanās armijas karavīriem ir izveidotas vairākas piemiṇas vietas (skvēri, pieminekḷi u. c.). Kopumā pilsētas teritorijā ir četri šāda veida objekti.

Pirmais ierīkots jau 1948. gadā pilsētas skvērā netālu no Rēzeknes Vissvētākās Dievdzemdētājas piedzimšanas pareizticīgo baznīcas. Šajā vietā apglabāts Sergejs Čerņikovs (1914-1944) un vēl astoṇi Sarkanās armijas karavīri (LNA RZVA, 18-1-302-20-21, Ul. Darzu). Jāatzīmē, ka 1959. gadā blakus šim obeliskam tika pārapbedīts padomju varas aktīvists Jānis Zvīdra (1895-1920) (Strods 2020b; par J. Zvīdra pārapbedīšanu 1959, 130, 2), savukārt 2009. gada jūlijā atklāts piemineklis sešpadsmit t. s. Afganistānas karā9 kritušajiem karavīriem (Rancāne 2009).

Vēl viena pieminas vieta Sarkanās armijas karavīriem pēckara gados iekārtota Rēzeknes Pareizticīgo kapsētas teritorijā Upes ielā. Šeit 1975. gadā atklāta piemiṇas zīme (Juškāne 2005). Pēc pieejamās informācijas, šajā vietā apbedīti 80 Sarkanās armijas karavīri (Ul. Upes).

Lielākais no padomju karavīriem veltītajiem Otrā pasaules kara objektiem izveidots Miera ielā, blakus Latvijas Neatkarības karā (1918-1920) kritušajiem un vēlāk kara hospitālī mirušajiem karavīriem. Šajos kapos 1968. gada 8. maijā atklāts tēlnieka Oto Kalēja (1920-1977) veidotais bronzas bareljefs $(1968,55,1)$. Kopumā Miera ielā apbedīti 545 sarkanarmieši (U1. Miera), tomēr LPSR Komunistiskās partijas Centrālās komitejas izveidotās komisijas pārstāvju 1959. gada 12. oktobra apsekošanas protokolā minēti 323 ierindas karavīri un virsnieki (LNA-RZVA, 18-1-302-20). Šāda skaitḷu atškịirība, iespējams, varētu būt skaidrojama ar dažādiem veiktajiem pārapbedījumiem. Jāpiekrīt viedoklim, ka Rēzeknē pamatā apbedīti no apkārtējām teritorijām pārvestie kritušie sarkanarmieši ${ }^{10}$ (Neiburgs 2018, 204). Turklāt jāṇem vērā, ka pašā pilsētā ielu kaujas nemaz nenotika (Nikonov 2018, 468). To savā ziṇā apstiprina fakts, ka vācu spēki pilsētu atstāja jau 1944. gada 26.-27. jūlija naktī (Neiburgs 2018, 202-203; Nikonov 2018, 468), respektīvi, pirms padomju spēku ierašanās. Jāatzīmē, ka šo 
apbedījumu teritorijā 2020. gada 24. oktobrī notika arī 62 bijušās karagūstekņu nometnes "Stalag 347" ieslodzīto mirstīgo atlieku pārapbedīšana (Poznakovs 2020, 42, 4).

Miera ielas kapsētā vairākkārt ir veikti dažādi atjaunošanas darbi, kurus finansiāli atbalstījusi Krievijas Federācija. Pēdējā renovācija šajā apbedījumu vietā notika 2016. gadā, un tās izmaksas bija aptuveni 28 tūkstoši dolāru (Čigāne 2016). Šāda veida atjaunošanas darbi notiek uz 2007. gadā Latvijas-Krievijas parakstītā savstarpējā līguma pamata (Par Latvijas Republikas valdības un Krievijas Federācijas valdības vienošanos par Latvijas apbedījumu statusu Krievijas Federācijas teritorijā un Krievijas apbedījumu statusu Latvijas Republikas teritorijā 2008) - Krievijas puse atjauno Sarkanās armijas karavīru apbedījumu vietas visā Latvijas teritorijā.

Ievērojamākais piemineklis Sarkanās armijas karavīriem - t. s. Aḷoša (saukts arī par pieminekli "Rēzeknes atbrīvotājiem") - atklāts 1976. gada 3. jūlijā netālu no Rēzeknes autoostas (Grava 1976, 80, 1; Līpenīte, Strods 2020, 82). Ik gadu pie pieminekḷa 9. maijā notiek t. s. Uzvaras dienas svētki, kuri pulcē ievērojamu cilvēku skaitu. Atceres pasākumos aktīvi iesaistās Otrā pasaules kara veterānu un viṇu pēcteču biedrība "Antihitleriskās koalīcijas cīnītāju Latvijas asociācijas Rēzeknes reǵionālā organizācija" (turpmāk tekstā - "RRO LAKCA"), tāpat pilsētas pašvaldības vadība, kā arī Krievijas Federācijas generālkonsulāts Daugavpilī u. c. Iepriekš pieminētā

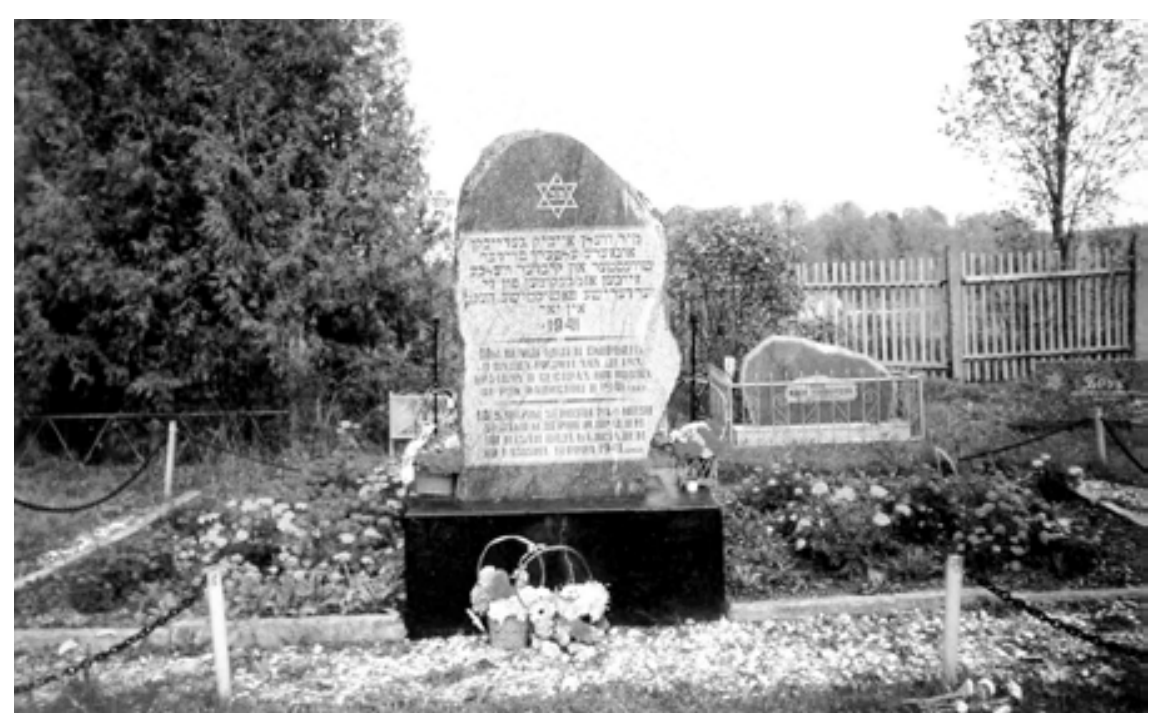

2. attēls. Piemineklis holokausta upuriem Rēzeknes ebreju kapsētā, 20. gadsimta 90. gadi. Latgales Kultūrvēstures muzeja krājums

Figure 2. Monument to the victims of Holocaust at the Rēzekne Jewish cemetery, 1990s. Collection of Latgale Culture and History Museum 
biedrība "RRO LAKCA" sakarā ar 9. maija atceri periodiski iniciē dažādas citas piemiņas akcijas. Piemēram, ik gadu notiek pretrunīgi vērtētais "Nemirstīgā pulka" gājiens u. c. pasākumi.

Šis ir viens no sabiedrībā vispretrunīgāk vērtētajiem Sarkanās armijas karavīriem veltītajiem monumentiem Rēzeknē. Tas periodiski atspoguḷojas atšķirīgajos sabiedrības viedokḷos par padomju laika mantojumu, ko tostarp raksturo aicinājumi par tā demontāžu. Līdzìga iniciatīva tika pausta 2020. gada februārī. Tas raisīja zināmu ažiotāžu arī no Krievijas Federācijas puses. Piemēram, Krievijas ǵenerālkonsuls Daugavpilī Jevǵēnijs Kolesnikovs šādu ieceri komentēja ar tekstu, ka "tamlīdzīgas iniciatīvas pie mums Krievijā nosauktu par provokāciju” (I vnov' o cobitiiakh v g. Rezekne v gody voiny 2020). Savukārt Rēzeknes pašvaldības vadītājs Aleksandrs Bartaševičs, komentējot šādu ieceri, uzsvēra, ka šo pieminekli vietējie "mīḷi dēvē par Aḷošu", bet kritušajiem Sarkanās armijas karavīriem nav nekāda sakara ar sekojošajiem 50 gadu notikumiem (Bartaševičs 2020, 8, 2).

Lai gan šis un arī vairāki citi pieminekḷi ir padomju okupācijas perioda "produkti", tomēr to demontāža neatrisinās akūto "padomju mantojuma" problēmjautājumu, bet var radīt šḳelšanos Rēzeknes un, iespējams, arī visas Latvijas sabiedrībā. Šajā gadījumā jāpiekrīt arhitekta Pētera Blūma retoriskajam jautājumam, kurš, runājot par t. s. Uzvaras pieminekḷa Rīgā nojaukšanu, izteicās: “[..] Ar ko gan tad mēs būtu labāki par padomju režīmu, kas

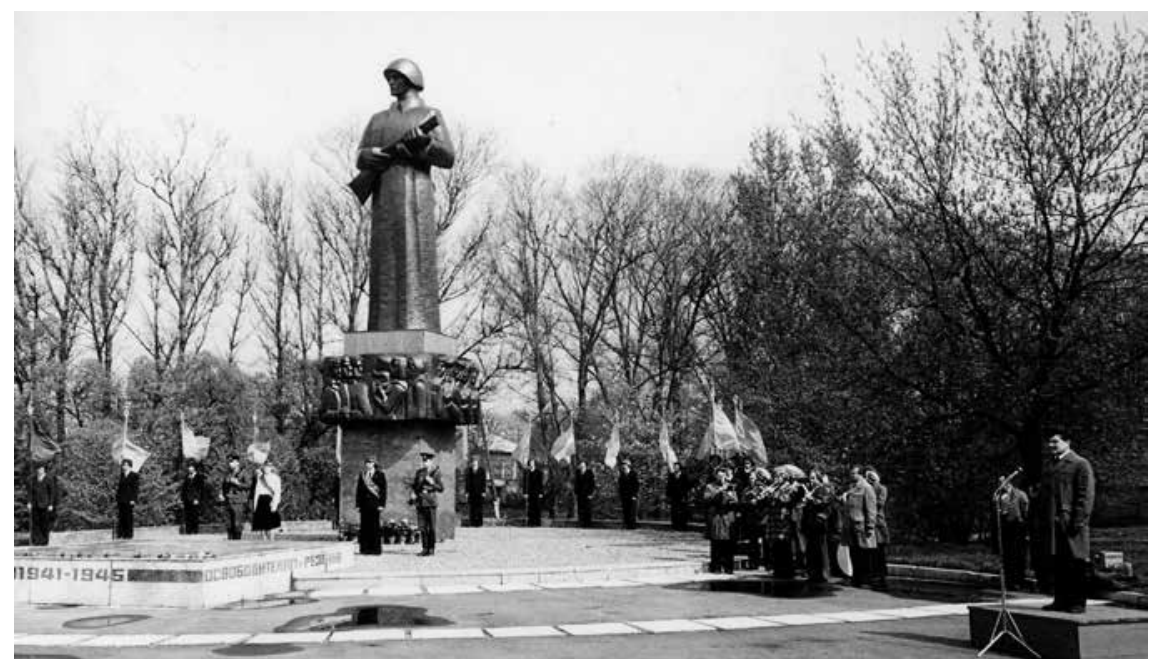

3. attēls. Pieminas pasākums pie padomju karavīriem veltītā pieminekḷa (tā sauktais Aḷša) Rēzeknē, 1977. gada 9. maijs. Latgales Kultūrvēstures muzeja krājums (LgKM 8676:2)

Figure 3. Memorial event at the monument to the Soviet soldiers (popularly known as Aḷoša) in Rēzekne, 9 May 1977. Collection of Latgale Culture and History Museum (LgKM 8676:2) 
centās izrēḳināties ar baznīcām un pieminekḷiem?” (Blūms 2020). Drīzāk tamlīdzīgās piemiņas vietās būtu nepieciešams izvietot vismaz informatīvos stendus, kuros bez padomju perioda ideologiskajiem uzslāņojumiem tiktu izskaidrota konkrētā monumenta vēsture un tā simboliskā nozīme gan pēckara, gan mūsdienu Latvijā. Vienlaikus būtu jāizvairās no Sarkanās armijas glorifikācijas un pēckara realitātes nolieguma.

Jāatzīmē, ka Latvijā ārpus padomju karavīriem izveidotajām masu apbedījumu vietām (brāḷu kapiem) ${ }^{11}$ līdz šim ir apzināti vairāk nekā 300 dažādi piemineklị, kuri "slavina padomju varu un okupācijas armiju" (Vỉksne 2020). Jāpiebilst, ka iepriekš minētajā sarakstā iekḷautas arī Rēzeknē 1961. gadā izveidotā piemiņas plāksne 1920. gada janvārī 16 par padomju varu kritušajiem k̦īniešiem, kā arī 1987. gada novembrī atklātais piemineklis cīnītājiem par padomju varu (1917.-1919. g.) (Āboltiņš 2020), kuras Atmodas un pirmajos atjaunotās Latvijas neatkarības gados ir demontētas. Iespējams, ka tamlīdzīga situācija ir vērojama arī attiecībā uz citiem šajā sarakstā iekḷautajiem pieminekḷiem un pieminas zīmēm.

\section{PADOMJU REPRESIJĀS CIETUŠAJIEM VELTİTĀS PIEMIṆAS VIETAS}

Padomju Savienības vadītāja Mihaila Gorbačova (1931) pagājušã gadsimta 80. gados uzsāktās reformas t. s. pārbūves ("perestroika") un atklātības ("glasnostj") iespaidā Latvijā aizsākās t. s. Atmodas periods (19861991). Tieši šajā laikā noritēja aktīva daudzu padomju simbolu (tostarp pieminekḷuu) demontāža, kā arī "aizmirsto" padomju represiju upuru pieminēšanas tradīcija.

Attiecīgajā laika periodā Rēzeknē izveidoja divas piemiñas vietas padomju represiju upuriem. Pirmo no tām ${ }^{12}$ 1990. gada 14. jūnijā atklāja Atbrīvošanas alejā 67 - teritorijā, kur 1941. gada jūnija beigās - jūlija sākumā (vietējās NKVD milicijas cietuma pagalmā) tika aprakti 35-39 nogalinātie Rēzeknes un tuvākās apkārtnes iedzīvotāji (Nikonov 2018, 337-339). Šìs vietas vēsture ir saistìta ar holokausta notikumiem. Proti, nogalināto cilvēku lịķu ekshumācijā 5. jūlijā ${ }^{13}$ iesaistīja no Rēzeknes cietuma atdzītos ebrejus, kurus pēc uzdevuma veikšanas nogalināja vietējie pašaizsardzības dalībnieki (Zellis 2017, 96-97). Nacistu varas iestādes šo padomju noziegumu izmantoja savu propagandas mērḳu îstenošanai, respektīvi, ebreja kā komunistu paveikto noziegumu tēla nostiprināšanai.

Par šiem notikumiem vērtīgas ziņas sniedz viens no 1942. gada vasarā sastādìtajiem Rēzeknes pilsētas policijas iecirkṇu darbības pārskatiem. Tajā minēts, ka tā paša gada 27. aprīlī bijušajā NKVD [patiesībā domāts milicijas cietuma - aut. piezīme] pagalmā izrakti sešu cilvēku līki, kurus 


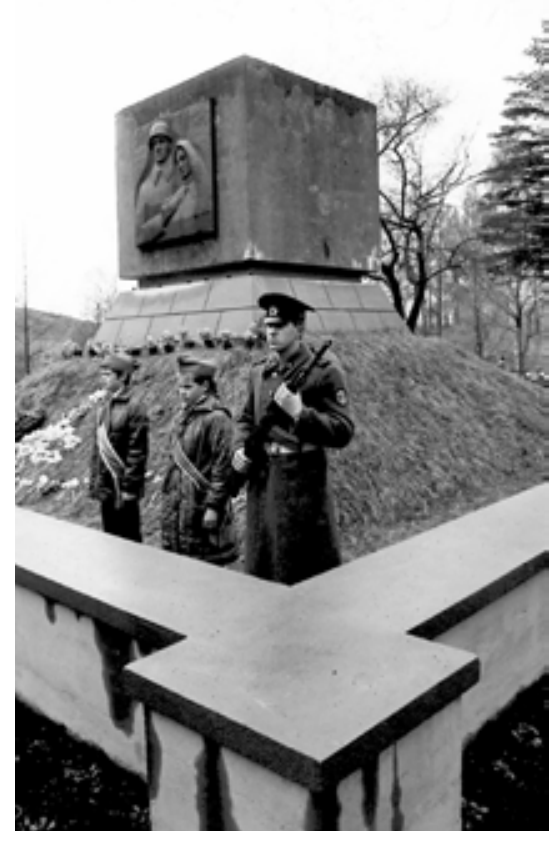

4. attēls. Piemineklis padomju karavīriem Miera ielā, 20. gadsimta 80. gadi. Latgales Kultūrvēstures muzeja krājums

Figure 4. Monument to the Soviet soldiers in Miera iela, 1980s.

Collection of Latgale Culture and History Museum

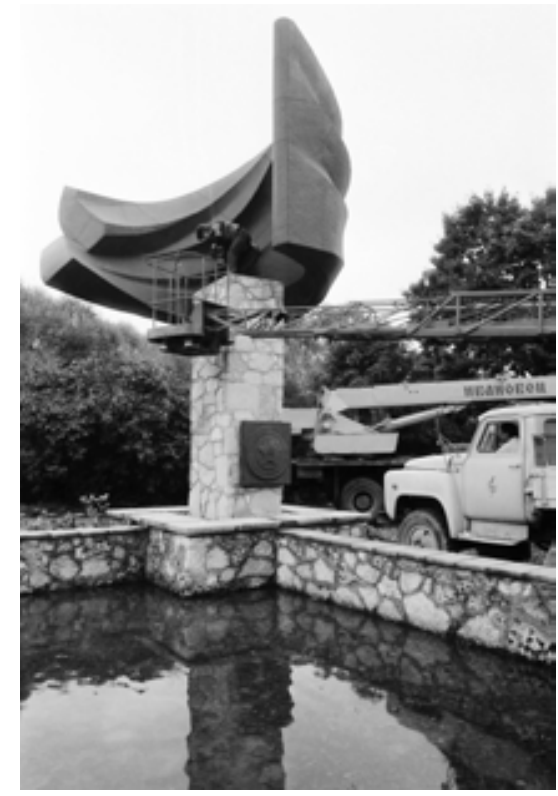

5. attēls. Padomju varas aktīvistiem veltìtā pieminekḷa demontāža Rēzeknē, 1991. gada 27. augusts. Latgales Kultūrvēstures muzeja krājums (LgKM 20840). Foto: A. Bondarenko

Figure 5. Dismantling of monument to the Soviet activists in Rēzekne, 27 August 1991, Collection of Latgale Culture and History Museum (LgKM 20840). Photo: A. Bondarenko

nogādāja Ančupānu kalnos ${ }^{14}$ (LNA-LVVA, 1371-1-14-225). Lai gan par šo notikumu detalizētākas informācijas trūkst, tomēr var pieņemt, ka šie ekshumētie cilvēki ir tie paši 1941. gada 5. jūlijā nogalinātie ebreji.

Acīmredzot, ka atsevišķos gadījumos padomju varas iestādes centās "slēpt" savus okupācijas perioda noziegumus. Par to liecina dienu pirms Rēzeknes "atbrīvošanas" 25 gadadienas (1969. gada 26. jūlijā) bijušās NKVD milicijas cietuma ēkas teritorijā atklātais piemiņas akmens "karavīriem atbrīvotājiem" (Atbrīvošanas svētki 1969, 90, 1). Savukārt 1987. gada novembrī Lielās Oktobra sociālistiskās revolūcijas 70. gadadienas priekšvakarā šajā vietā atklāja pieminekli (bareljefu) "padomju varas cīnītājiem" (Tihomirova 1987, 135, 1). Tomēr tas ilgi neatradās savā vietā, un pēc nepilniem četriem gadiem (1991. gada 27. augustā) to demontēja (LgKM 20840).

Konkrētā piemiņas vieta apliecina Otrā pasaules kara vēsturisko norišu kompleksumu, respektīvi, vienlaikus atspogul,ojas Padomju Savienības un 
nacistiskās Vācijas totalitāro režīmu noziegumi pret dažādām sabiedrības dạ̣ām, kā rezultātā Rēzekni var uzlūkot kā vienu no, britu vēsturnieka Timotija Snaidera vārdiem izsakoties, Austrumeiropas "asinszemes" piemēriem. Līdzīgu viedokli pauž arī vēsturnieks Kaspars Zellis, kurš secina, ka šāda pieeja "ḷauj akcentēt cilvēciskās, nevis etniskās vai politiskās kategorijas" (Zellis 2017, 103).

\section{SECINĀJUMI}

Otrā pasaules kara piemiñas vietas Rēzeknē apliecina attiecīgā laika perioda sarežğîto vēsturi, kā arī atklāj problēmjautājumus, kuri saistīit ar padomju un nacistu okupācijas režìmu represiju un propagandas lomu mūsdienu pastāvošajās pagātnes interpretācijas tendencēs.

Jākonstatē, ka Rēzeknē ir vērojama disproporcija starp Sarkanās armijas karavīriem un citiem Otrā pasaules kara upuriem veltīto piemiñas vietu skaitu, kas skaidrojams ar padomju varas periodā izteikto ideoloǵisko akcentu - Sarkanās armijas kā "atbrīvotājas" tēla nostiprināšanu. Šie monumenti joprojām saglabā izteikti padomisko vēstures naratīvu. Diemžēl pēdējo gadu laikā pilsētas pašvaldības vadības îstenotā "pieminas politika" attiecībā uz 9. maija jeb t. s. Uzvaras svētku atceri liek domāt par mākslīgu padomju okupācijas laika mītu (tradīiju) uzturēšanu, kā arī nevēlēšanos iesaistīties sabiedrības konsolidācijas procesos.

Lielākā daḷa no izveidotajām piemiņas vietām simboliski piesaistītas konkrētajiem Otrā pasaules kara notikumiem, kurās līdz pat mūsdienām norisinās dažādi atceres un piemiņas pasākumi. Neviennozīmīgie padomju režīma periodā veidotie pieminekḷi šodien dažādās sabiedrības daḷās nereti tiek uztverti atšķirīgi, kā rezultātā veidojas konfrontējošā naratīva aspekts. To veicina arī padomju perioda tradīciju uzturēšana un pilsētas pašvaldības nespēja veidot dialogu starp šīm sabiedrības daḷām. Līdz ar to vērojama nepieciešamība pēc jaunas, mūsdienīgas pieejas šāda dialoga izveidei, tajā pašā laikā izvairoties no padomju vēstures idealizēšanas un glorifikācijas. Vienlaikus rodas nepieciešamība padomju perioda piemiñas vietās izvietot mūsdienīgus informatīvos stendus, ar kuru starpniecību varētu izglìtot sabiedrību, jo nereti cilvēkiem trūkst zināšanu (informācijas) par konkrētās piemiņas vietas vēsturi (notikumu un izveides procesu) un nozīmi mūsdienās.

Padomju mītu noturība un "vēsturiskā amnēzija" vērojama attiecībā uz 1944. gadā padomju aviācijas veikto pilsētas bombardēšanu, jo vairāk nekā 30 neatkarības gadu laikā nav izveidota neviena piemiñas vieta šo trağisko notikumu upuriem. Tāpat jāsecina, ka pilsētvidē nav izceltas ar holokausta laikā Rēzeknē izglābto ebreju likteņiem saistîtās vietas (ēkas). 
Visi pilsētas teritorijā izveidotie pieminekḷi ir mūsu sarežğītās un traumatiskās Otrā pasaules kara pagātnes liecības, kam ir nozīmīgs potenciāls pilnvērtīgākai mūsu vēstures izpratnei, sabiedrības izglītošanai u. c. procesos.

\section{SAĪSINĀJUMI}

LNA-LVVA - Latvijas Nacionālā arhīva Latvijas Valsts vēstures arhīvs

LNA-RZVA - Latvijas Nacionālā arhīva Rēzeknes zonālais valsts arhīvs

LPSR - Latvijas Padomju Sociālistiskā Republika

\section{IZMANTOTIE AVOTI UN LITERATŪRA}

\section{AVOTI}

Āboltiņ̌s, A., 2020. Pārskats par 313 "padomju laikā" uzstādītiem pieminekḷiem un ierīkotām piemiñas vietām ārpus apbedijumu vietām (brālu kapiem), kuras saistitas ar Otro pasaules karu un Sarkano armiju un kuras vēl ir saglabājušāa (nav zinu par nojaukšanu vai demontāžu). Pieejams: https://nra.lv/_files/202006/parskats_ padpiemSA-A1-202006.pdf [Skatìts 01.06.2021.]

B. a., 1959. Viņš cīnījās par mūsu laimi. J. Zvīdra mirstīgo atlieku apbedīšana Rēzeknē. Ausma, 130, 2.

B. a., 1965. Pie fašisma upuru sienas. Znamja Truda, 87, 1.

B. a., 1968. Dzimtene sēro līdz ar varoṇu mātēm. Mītiṇi Brāḷu kapos. Znamja Truda, $55,1$.

B. a., 1969. Atbrīvošanas svētki. Znamja Truda, 90, 1.

B. a., 1941. Komunistu-žìdu briesmu darbi Rēzeknē. Tēeija, 13, 6.

B. a., 1941. Krievu ārsts "aizmirsis" slimnieku ar uzškēêrstu vēderu uz operācijas galda. Daugavpils Latviešu Avize, 36, 3.

Bartaševičs, A., 2020. Pieprasa demontēt pieminekli "Aḷoša”. Rēzeknes Vēstnesis, 8, 2.

Blūms, P., 2020. Pēteris Blūms: Ceru, ka mūsu valsts neḳersies pie pieminekḷu nojaukšanas, lai "ieriebtu krieviem". LA.LV. Pieejams: https://www.la.lv/ nekarosim-pret-pieminekliem [Skatìts 20.11.2020.]

Bruzgule, V., 1990. Lai neviens nav aizmirsts. Darba Karogs, 140, 3.

Čigāne, I., 2016. Rēzeknē par Krievijas naudu atjauno kritušo sarkanarmiešu kapus, LSM.LV. Pieejams: https://www.lsm.lv/raksts/zinas/latvija/rezekne-par-krievijasnaudu-atjauno-krituso-sarkanarmiesu-kapus.a190334/ [Skatīts 17.11.2020.]

Gilis, V., 2020. Būs Vipingā piemiņas aleja! Rēzeknes Vēstis, 36, 1.

Grava, V., 1976. Cauri liesmām pretī uzvarai... Pieminekḷa atklāšana Rēzeknes atbrīvotājiem. Znamja Truda, 80, 1.

I vnov' o cobitiiakh v g. Rezekne v gody voiny. Pieejams: https://www.facebook.com/ MIDRussia/posts/d41d8cd9/2448166031949490/ [Skatits 17.11.2020.]

Juškāne, I., 2005. Rēzeknes pilsētas kultūrvēstures objekti. Par Rēzeknes pilsētas kultūrvēstures objektu saglabāšanu, atklāšanu un likvidēšanu, Likumi.lv. https:// likumi.lv/ta/id/112758-par-rezeknes-pilsetas-kulturvestures-objektu-saglabasanuatklasanu-un-likvidesanu [Skatìts 27.11.2020.]

Magone, M., 1989. Rēzekne atceras. Darba Karogs, 90, 1. 
Materiali zhertv fashisma. LNA-RZVA, 18-1-302.

Mītiņš pie padomju karavīriem veltītā pieminekḷa (t. s. Aḷoša) Rēzeknē, 1977. gada 9. maijs. Latgales Kultūrvēstures muzeja krājums (LgKM 8676: 2).

Nagle, G., 2020. Sarkanās zvaigznes joprojām spīd, IR. Pieejams: https:// ir.lv/2020/06/17/sarkanas-zvaigznes-joprojam-spid/ [Skatîts 15.01.2021.]

Nizinska, M., 1990. Deg sveces piemiņai. Atklāta memoriālā plāksne audriniešiem. Darba Karogs, 3, 1.

Padomju varas aktīvistiem veltītā pieminekḷa demontāža Rēzeknē, 1991. gada 27. augusts. Latgales Kultūrvēstures krājums (LgKM 20840).

Par Latvijas Republikas valdības un Krievijas Federācijas valdības vienošanos par Latvijas apbedījumu statusu Krievijas Federācijas teritorijā un Krievijas apbedījumu statusu Latvijas Republikas teritorijā. Likumi.lv. Pieejams: https://likumi.lv/ta/id/179009par-latvijas-republikas-valdibas-un-krievijas-federacijas-valdibas-vienosanos-parlatvijas-apbedijumu-statusu-krievijas-federacijas [Skatīts 17.11.2020.]

Rēzeknes ebreju kapsētā, 20. gs. 90. gadi. Latgales Kultūrvēstures muzeja krājums.

Piemiņas akmens 1941. gada jūnija-jūlija padomju represiju upuriem. A. Bondarenko privātais arhīvs.

Pieminas pasākums padomju karavīru kapsētā Miera ielā, 20. gs. 80. gadi. Latgales Kultūrvēstures muzeja krājums.

Pozṇakovs, K., 2020. Pārapbedītas ziemeḷu rajonā atrastās karavīru mirstīgās atliekas. Rēzeknes Vēstnesis, 42, 4.

Rancāne, A., 2009. Rēzeknē atklāts piemineklis kritušajiem "afgāņiem”, Diena.lv. Pieejams: https://www.diena.lv/raksts/latvija/zinas/rezekne-atklats-pieminekliskritusajiem-afganiem-677533 [Skatìts 15.01.2021.]

Rēzeknes apriṇka priekšnieka pārvaldes Administratīvās daḷas akts Nr. 8./4. Ziṇojumi par stāvokli. LNA-LVVA, 1371-1-14.

Salnītis, V. (sast.), 1936. Ceturtā tautas skaitišana Latvijā 1935. gadā. Iedzìvotāju skaits, dzimums un pavalstniecỉba. Rīga: Valsts Statistikas pārvalde.

Tihomirova, A., 1987. Viṇu piemiṇa mūžam dzīva. Veltīts revolūcijas cīnītājiem. Znamja Truda, 135, 1.

ul. Darzu. Pieejams: Память народа::Воинские захоронения: ул. Дарзу (раmуatnaroda.ru) [Skatìts 17.11.2020.]

ul. Miera. Pieejams: https://pamyat-naroda.ru/memorial/burial.php?id $=85908507 \&$ static_hash =14d0cf87bc91083dbd9d8f79f90d7def [Skatīts 17.11.2020.]

ul. Upes. Pieejams: https://pamyat-naroda.ru/memorial/burial.php?id=85908712\&static_hash $=14 \mathrm{~d} 0 \mathrm{cf87b} 91083 \mathrm{dbd} 9 \mathrm{~d} 8 \mathrm{f} 79 \mathrm{f} 90 \mathrm{~d} 7 \mathrm{def}$ [Skatìts 17.11.2020.]

Utāns, E., 2020. Iestādīja 75 bērzus. Rēzeknes Vēstis, 89, 2.

Vīksne, I., 2020. Krievijas stratēgiskā komunikācija Latvijas kapos. nra.lv. Pieejams: https://neatkariga.nra.lv/izpete/318226-krievijas-strategiska-komunikacijalatvijas-kapos [Skatits 01.06.2021.]

\section{LITERATŪRA}

Bērziņš, D., 2015. Sociālās atmiņas komunikācija un ètika: holokausta diskursi Latvijā (1945-2014). Promocijas darbs. Rīga: Latvijas Universitāte.

Ezergailis, A., 1999. Holokausts vācu okupētajā Latvijā 1941-1944. Rīga: Latvijas vēstures institūta apgāds.

Līpenīte, A., Strods, K., 2020. 100 fakti par Rēzekni. Rēzekne: Latgales Kultūrvēstures muzejs. 
Lowe, K., 2020. Prisoners of history. What monuments to the Second World War tell us about our history and ourselves. London: William Collins.

Malahovskis, V., 2019. Nacistiskās Vācijas okupācijas varas Audriṇu sādžas iedzīvotāju iznīcināšanas akcijas krimināllietas Nr. 31 materiālu vēsturiskā nozīme. Mežulis, D. (galv. red.). Administratīiā un kriminālā justicija, Nr. 1. Pieejams: http://journals. ru.lv/index.php/ACJ/article/view/4018/4302 [Skatīts 15.01.2021.]

Memorial, Academic.ru. Pieejams: https://illustrated_dictionary.academic.ru/6945/\% D0\%9C\%D0\%B5\%D0\%BC\%D0\%BE\%D1\%80\%D0\%B8\%D0\%B0\%D0\%BB [Skatīts 01.06.2021.]

Neiburgs, U., 2018. “Grēka un ienaida liesmās!” Latvijas Otrā pasaules kara stāsti. Rīga: Latvijas Mediji.

Nikonov, V., 2018. Rezekne pered tretim prishestviem. Rezekne: Nacionālo un reliǵisko kultūru pētniecības centrs.

Pamiatnik, Academic.ru. Pieejams: https://dic.academic.ru/dic.nsf/ushakov/919814 [Skatīts 01.06.2021.]

Strods, K., 2017. Ebreju Rēzekne. Zelča-Sīmansone, I. (sast.). Ebreju Rēzekne. Rīga: Creative Museum.

Strods, K., 2020a. Dzive aiz dzeloṇstiepḷu žoga - padomju karagūstekņu nometne "Stalag 347", LSM.LV. Pieejams: https://www.lsm.lv/raksts/dzive--stils/vesture/ dzive-aiz-dzelonstieplu-zoga--padomju-karagusteknu-nometne-stalag-347.a358157 /?fbclid = IwAR2cVtxE18ufzRRsBrOSXaFrkf5rnS65SoEs641_3Qnpw-IioIteS41gHbw [Skatīts 21.01.2021.]

Strods, K., 2020b. No Latgales zemnieka dēla līdz komunisma ideologam. Stāsts par Jāni Zvīdru. LSM.LV. Pieejams: https://www.lsm.lv/raksts/dzive--stils/vesture/nolatgales-zemnieka-dela-lidz-komunisma-ideologam-stasts-par-jani-zvidru.a376934 /?fbclid= IwAR0Qz9GL2guxBoL1pGgWi1nRyxGOVqSTKxcqrzJxbaDG209jHhCsgU 9j_Os [Skatīts 21.01.2021.]

Zellis, K., 2011. 8./9. maijs un tā atspoguḷojums vēstures literatūrā. Muižnieks, N., Zelče, V. (red.). Karojošā piemiña. 16. marts un 9. maijs. Rīga: Zinātne.

Zellis, K., 2017. Holokausts Rēzeknē: izpētes problēmas, jautājumi, perspektīvas. ZelčaSīmansone, I. (sast.). Ebreju Rēzekne. Rīga: Creative Museum.

\section{ATSAUCES UN PIEZİMES}

${ }^{1}$ Arhitektoniska vai skulpturāla būve, kas veidota, pieminot vai godinot kādu ievērojamu cilvēku vai notikumu (pamiatnik).

${ }^{2}$ Arhitektoniska celtne, celtṇu komplekss, kāda cilvēka, cilvēku grupas vai notikuma pieminai (memorial).

${ }^{3}$ Starp šiem darbiem jāmin Vitas Zelčes pētījums par Otrā pasaules kara pieminekḷiem Baltijas valstīs. (Zelče, V., 2010. Atmiṇas tekstūra. Otrā pasaules kara pieminekḷi Baltijas valstīs. Latvijas sociāla atmina un identitāte. Manuskripti. 1. laidiens. Rīga: Valsts pētījumu programma "Nacionālā identitāte". Pieejams: https://www.researchgate. net/publication/344176525_Zelce_Vita_2010_Atminas_tekstura_Otra_pasaules_kara_ pieminekli_Baltijas_valstis_The_Texture_of_Memory_World_War_II_Monuments_in the_Baltic_States_Riga_ASPRI_40_pages_Social_Memory_of_Latvia_and_Identi [Skatīts 21.01.2021.] Savukārt Rīgas pieminekḷu aǵentūras oficiālajā vietnē ir apkopota informācija par visiem svarīgākajiem Otrā pasaules kara pieminekḷiem Rīgā un Rīgas rajonā (Rīgas pieminekḷu aǵentūra. Pieejams: http://www.rigaspieminekli. lv $/$ ?lapa $=$ pieminekli\&rajons $=2$ [Skatīts 15.01.2021.]). Plašāku pārskatu par Rīgas un tās apkārtnē esošajām piemiņas vietām sagatavojusi Latvijas Okupācijas muzeja biedrība (skat. Čakstiņa, K., Pētersons, R., 2017. Piemiņas vietu cel̦vedis pa Rìgu 
un Rigas apkārtni. Rīga: Latvijas Okupācijas muzeja biedrība). Jāatzīmē, ka šis ir bilingvāls izdevums - latviešu un angḷu valodā.

${ }^{4}$ Šajā izdevumā iekḷauta nozīmīga informācija par Latvijas ebreju kopienu, kā arī holokausta iznīcināšanas vietām (Melers 2013). Tāpat jāatzīmē muzeja "Ebreji Latvijā" izdotais katalogs "Holokausta piemiṇa Latvijā laika gaitā (1945-2015)" (Lenskis 2017).

${ }^{5}$ Skat. Strods, K., 2017. Ebreju Rēzekne. Zelča-Sīmansone, I. (sast.). Ebreju Rēzekne. Rīga: Creative Museum.

${ }^{6}$ Muižnieks, N., Zelče, V. (red.). 2011. Karojošā piemiña. 16. marts un 9. maijs. Rīga: Zinātne.

${ }^{7}$ Kaprāns, M., Zelče, V. (red.) 2010. Pēdējais kařs: Atmina un traumas komunikācija. Rìga: LU SZF SPPI; Kaprāns, M., Procevska, O., Uzule, L. u. c., 2012. Padomju deportāciju pieminēšana Latvijā. Atmiņu politika un publiskā telpa. Rīga: Mansards.

${ }^{8}$ Pirmā piemiņas zīme šajā vietā izveidota 1974. gadā (Juškāne 2005).

${ }^{9}$ Militārs konflikts starp Padomju Savienību un Afganistānas Demokrātisko Republiku (1979-1989).

${ }^{10}$ To netieši apstiprina arī Krievijas Federācijas Aizsardzības ministrijas veidotajā elektroniskajā datubāzē "Memorial" ("Мемориал") pieejamā informācija par Rēzeknes kapsētā apbedītajiem sarkanarmiešiem. Proti, jākonstatē, ka daudzi no Miera ielā apbedītajiem Sarkanās armijas karavīriem ir gājuši bojā vairākas nedēlas vai pat mēnešus pēc padomju spēku ienākšanas Rēzeknē 1944. gada 27. jūlijā.

${ }^{11}$ Pēc Brāḷu kapu komitejas apkopotās informācijas, Latvijā ir 346 šāda veida apbedījumu vietas (Vīksne 2020).

12 Otrā pieminas vieta veltīta 1941. un 1949. gadā no Rēzeknes deportētajiem iedzīvotājiem. Tā atklāta 1991. gadā pie dzelzceḷa stacijas Rēzekne II (Juškāne 2005).

${ }^{13}$ Lai gan ir ziṇas, ka NKVD milicijas cietumā nogalināto personu ekshumācija notikusi 7. jūlijā (Ezergailis 1999, 327; Zellis 2017, 97), tomēr pēc vienā no nacistu okupācijas laikā iznākošajā periodiskajā izdevumā "Daugavpils Latviešu Avīze" iekḷautās informācijas tas noticis 5. jūlijā, savukārt nākamajā dienā (6. jūlijā) notika šo personu apbedīšanas ceremonija (Krievu ārsts "aizmirsis" slimnieku ar uzšksērstu vēderu uz operācijas galda 1941, 36, 3.). Arī pēc rēzeknieša M. Bacmanova teiktā, līḳu ekshumācija [NKVD - aut. piezīme] milicijas pagalmā veikta 5. jūlija pēcpusdienā (Nikonov 2018, 337). Jāatzīmē, ka par 6. jūlijā Rēzeknē notikušo bēru ceremoniju ziņoja arī nacistu okupētās Latvijas oficiozs "Tēvija" (Komunistu-žīdu briesmu darbi Rēzeknē 1941, 13, 6).

${ }^{14}$ Domāta vieta, kur nacistu okupācijas režīms veica ebreju, romu, padomju karagūsteknuu u. c. cilvēku masu iznīcināšanas akcijas (skat. Strods, K., 2020. "Viņi mira, lai dzīvotu Tu": Ančupānu memoriāls. No Purinaša, L., Strods, K. Laikmeta nospiedumi: 20. gadsimta Latgales stāsti. Rēzekne: Hronologeja). 


\title{
DIFFICULT HERITAGE OF LATVIA: \\ INSIGHT INTO THE MEMORIAL PLACES \\ OF WORLD WAR II IN RËZEKNE (1945-1991)
}

\author{
KASPARS STRODS \\ MA in archival science, researcher at the University \\ of Latvia Institute of Philosophy and Sociology, \\ historian at the Latgale Culture and History Museum \\ E-mail: kaspars.strods88@inbox.Iv
}

ABSTRACT

The aim of the current publication is to explorecreation of specific memorial sites, the process of their historical development, as well as their contemporary significance. The study is based on the various printed publications of the times of Soviet occupation and independence of Latvia (“Ausma”, "Znamja Truda”, "Rēzeknes Vēstnesis", etc.), as well as the collections of the Latgale Culture and History Museum, the National Archives of Latvia and other sources.

Keywords: Memorial places, World War II, Soviet Union, Nazi Germany, Rēzekne.

\section{SUMMARY}

The World War II memorial sites in Rēzekne confirm the complexity of this historical period, as well as allow to detect problems which are related to the role of repressions and propaganda by the Soviet and Nazi occupation regimes in contemporary interpretations of the past.

It should be noted that in Rezzekne there is a disproportion between the number of memorial places which are dedicated to the Red Army soldiers and to other victims of World War II. That can be explained by the ideological emphasis maintained during the Soviet era - strengthening the image of the Red Army as a "liberator". At the same time, these monuments retain a distinctly Soviet historical narrative.

Most of the created memorial sites are symbolically associated with specific events of the World War II, where various commemorative and memorial events take place until the present day. Today, the controversial monuments created under Soviet rule are often perceived differently in various parts of society, which leads to a confrontational narrative. This is also facilitated by the preservation of the Soviet era traditions and the 
inability of the city council to establish a dialogue between these parts of society. Consequently, there is a need for a new, contemporary approach to establishing such a dialogue, at the same time avoiding idealization and glorifying of the Soviet narrative. Furthermore, memorials of the Soviet era require introduction of modern information stands, which would contribute to the education of society, since people often lack knowledge and information about the history (the events and the process of creation) and meaning of the memorials today.

All the monuments established in the city are an evidence of our complex and traumatic past of the World War II, which has a significant potential for improving the understanding of our history, educating and consolidating various groups of society. 


\title{
EVOLUTION OF PUBLIC HOSPITAL ARCHITECTURE DURING THE INTERWAR LITHUANIA
}

\section{EVALDAS VILKONČIUS}

Ph. D. student at the Faculty of Arts, Vytautas Magnus University

E-mail: evaldas.vilkoncius@vdu.It

\begin{abstract}
When Lithuania became an independent state, most hospitals were operating in unsuitable buildings. Therefore, many new modern buildings for hospitals had to be built in various cities. However, the changes in hospital architecture during the interwar period still remain unexplored. Therefore, by analysing the key examples, the current article discusses the evolution of hospital buildings during the interwar Lithuania.
\end{abstract}

Keywords: modern architecture, hospitals, Lithuanian architecture, modernism, hospital architecture.

\section{INTRODUCTION}

Even though during the interwar period quite a few new hospital buildings were built in Lithuania, the evolution of architecture revealed by these buildings still remains scarcely studied. Until now, only a few Lithuanian researchers have delved into this subject in broader context (Šimulyte 2007, 2-3), while other studies are limited to the analysis of individual hospital buildings (Kilinskaitè, 2013).

Despite that, a lot of historical sources related to the design of new hospital buildings can be found in the Lithuanian Central State Archives and Vilnius Regional State Archives. These archives store many original design projects of the interwar hospital buildings, documents related to their design, construction. Furthermore, information related to the design 
and construction of hospitals, as in the case of other buildings, was widely published in the periodicals of that time. In addition, there are some foreign studies related to the general evolution of hospitals in the Western countries (Willis et al. 2019).

The novelty of this article lies in the aim for the first time in the historical context of interwar Lithuanian architecture to analyse several cases representing the most original and typical hospital buildings that would help to understand the evolution of such buildings of that time. Therefore, from a chronological point of view, using analytical and comparative methods based on unpublished archival material (original hospital design projects, documentation related to their design), the various periodicals of that period (articles) and studies of foreign architectural historians, the article tries to reveal the evolution of the architecture of interwar Lithuanian hospitals and the main tendencies and causes of this process.

\section{CONSTRUCTION OF NEW PUBLIC HOSPITAL BUILDINGS DURING THE INTERWAR LITHUANIA}

After Lithuania became an independent state, in addition to all the other significant issues, care was taken to protect public health by developing the system of institutions dedicated to that purpose. The most important medical care providers were public hospitals. In total, there were about forty public hospitals in Lithuania at that time (Meškauskas 1987, 297).

While some hospitals were established in special buildings constructed during the tsarist period, others were housed in unsuited premises (TallatKelpša 1932, 4). A situation was similar in other types of public buildings, as many of them at the beginning of independence period did not meet the minimum standards of cleanliness, space, and comfort. Consequently, efforts were made to build new edifices to have at least a required minimum of new public buildings (schools, hospitals, etc). Thus, these buildings were considered as one of the priorities for larger towns (LCVA, 377-8-169, 72).

It is known that during that period entirely new public hospital buildings were erected in such towns as Alytus, Kaunas, Kèdainiai, Klaipeda, Lazdijai, Marijampolè, Mažeikiai, Panevėžys, Raseiniai, Šakiai, Šiauliai, Tauragè, Telšiai, Zarasai, while in other towns, as in Rokiškis and Utena, hospitals were modernized by building new annexes to older buildings (Sniegulis 1938, 6). Also, there were plans to build new hospital buildings in Biržai, Kaišiadorys, Kretinga, Ukmergè, Vilkaviškis, but these were not realized until the end of the independence period. This shows that there was a need to have modern hospitals in larger towns of Lithuania and this 
may have led to the search for new architectural possibilities to make these buildings as suitable as possible for performance of their function.

The largest public hospitals belonged to municipalities, except for Red Cross, which also had a few hospitals in Lithuania. Consequently, it was their responsibility to take care of their modernization and they largely financed (using their own finances or loans) this process. Also, many new buildings for such hospitals were mainly designed by local architects (known as building engineers and technicians), who worked in municipalities and designed other public buildings as well, such as schools, etc.

\section{ASPIRATIONS TO MODERNIZE HOSPITALS IN LITHUANIA IN THE 1920s}

In the view of the pressing situation, when "hospitals were in need of new premises and equipment" (Sniegulis 1937, 374), the first attempts to improve their situation began in the early 1920s. For example, in 1923 the project of the new building of Mažeikiai Hospital was implemented (arch. B. Helcermanas). It was a wooden one-storey building, the exterior of which was typical of traditional architecture. Similar approach was during the modernization of Panevezzys Municipality Hospital. There, between 1923 and 1927 special buildings were designed for the main, surgical, and contagious diseases departments, mortuary, laundry. All of them except the main building were intended for temporary use only and lacked architectural innovation - constructed of wood and traditional in appearance. Largest of them was the main two-story building (arch. G. Gumeniukas). According to the standards of that time, the building was quite modern had central heating, special treatment rooms and masonry construction. The exterior of the building reflected the tendencies of the country's architecture of the period - the main symmetrical façade was emphasized by a massive pediment, columns, pilasters, typical of neoclassical stylistics. Moreover, inside the building all the rooms were arranged according to the laws of symmetry, not convenience.

\section{DESIGNING NEW HOSPITALS IN LITHUANIA OF THE EARLY 1930s}

The beginning of the 1930s in the context of Lithuanian hospital architecture can be associated with attempts to observe the achievements of other countries in the construction of such buildings. After the decision to build a hospital in Šiauliai in 1930, a city and municipality delegation 


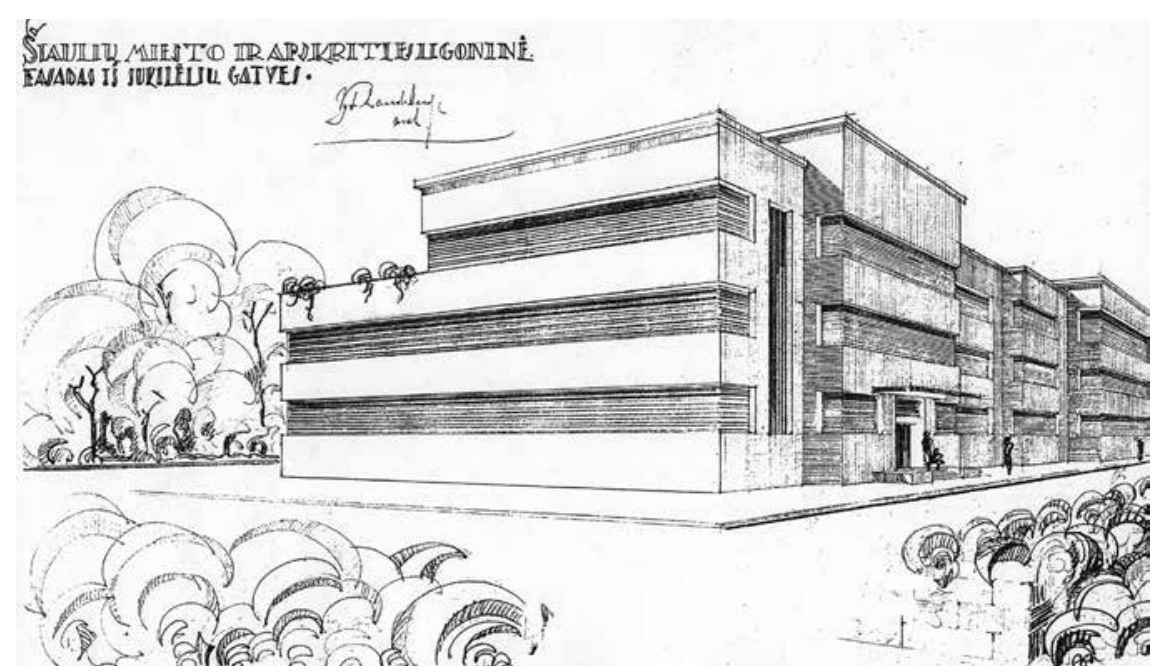

Figure 1. Project of Šiauliai hospital (not built), 1931 (Vilnius Regional State Archive)

went to Berlin and Dresden in Germany to get acquainted with the latest hospital buildings. This suggested that abroad such buildings were both internally and externally designed to be fully adapted to their function, which was not a common feature of Lithuanian hospitals at that time. Arguing that Lithuanian architects had not yet had "sufficient experience in the construction of hospitals" (LCVA, 862-1-2649, 98), German architect Paul Wolf was invited to make a design proposal of the new hospital in Šiauliai. The study found that this was one of the first times when a foreign architect was invited to design a public hospital.

To hold a small competition for the design, local specialists G. Gumeniukas and V. Landsbergis-Žemkalnis were also instructed to make a design proposal (Figure 1). For example, in the latter project an important external accent was to be the large balconies, and the unadorned façade with continuous strip windows, for the first time showing the influence of modernist aesthetics, which could have been a big novelty in Lithuanian hospitals (VRVA, 1171-1-255, 1). However, the building was not built, as the projects were thought to be overly ambitious and expensive.

It can be said that the interest in the latest trends of foreign hospitals had been stimulated by the efforts to carry out comprehensive modernization of hospitals in Lithuania. Such processes had already started in the Western countries, where the interiors of the new hospitals were designed with the latest medical achievements and requirements in mind. The exterior of such buildings also changed when the latest architectural style - modernism was applied. The changes in their architecture "embodied the ideas and 
appearance of hygiene, efficiency, functionality" (Willis et al. 2019, 214). Therefore, modernism in hospital architecture was not just an aesthetic change. The programmatic aspirations of modernism, such as functionality, sunlight, fresh air, purposeful layout of rooms, etc., also resonated in hospital architecture, where these architectural possibilities "began to play an active role in the treatment and healing of patients" (Willis et al. 2019, 214).

The newest architectural trend of modernism had not yet had a significant influence on Lithuanian architecture, and it was thought that the most important accents of modern hospitals were "not the latest achievements in art or architecture", but the interior installation and functionality of the building, for these hospitals, according to doctor F. Tallat-Kelpša, to "be a good and genuine institutions for correction of human health" (TallatKelpša 1932, 14).

For example, a significant event in hospital development was the construction of the municipality hospital in Taurage in 1932-1933 (arch. K. Reisonas) (Figure 2). The focus here was on the internal modernization. An irregular corner plan was applied. In such plan, the premises were functionally divided. The basement was intended for auxiliary rooms, one side of the ground floor and the second floor for the patient wards, while the other side was intended for administration, reception, the maternity and surgical wards. This innovative subdivision of the premises was based on the orientation of the building on the plot, as the aim was for the wards of the patients to face southwest - to receive direct sunlight not only to better illuminate the wards but also for treatment. This allowed to design massive balconies with exits from the wards in the southern part of the hospital. In addition, the treatment rooms were modern by the standards of that time - the operating room was illuminated with special lamps, the X-ray department had a research laboratory and bathtubs. Nevertheless, the exterior of the building was in the style of simplified historicism. The study found that a similar historicist appearance was also characteristic to the new buildings designed in 1933 for Zarasai (arch. J. Kadžys) and Šakiai (arch. A. Aleksandravičius) hospitals. The latter, however, was later redesigned and acquired a more modern looking exterior.

The fact that the internal modernization coincided with the influence of newest architectural trend - modernism can be justified in the case of Klaipeda Red Cross hospital (arch. R. Steikūnas), which was built in 1933. It was designed with a simple, minimalist look, which showed the impact of modernism. The façades, due to the desire for practicality, were diversified by wide windows to have well-lit rooms and loggias, which were intended for patients as a therapeutic measure, since access to them was provided from the wards. This can be considered as an attempt to reflect the latest architectural trends of foreign hospitals at that time, where open spaces 


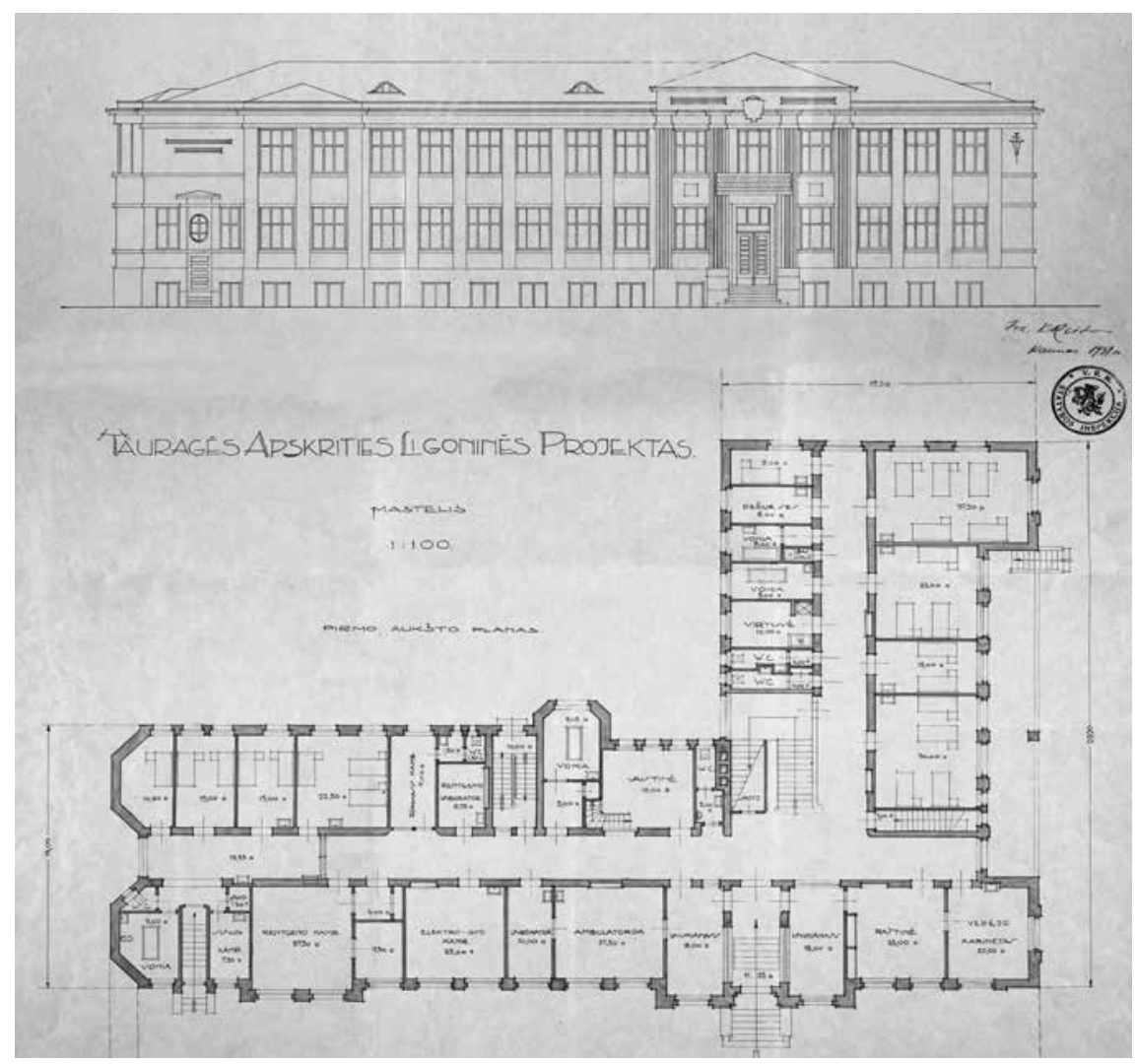

Figure 2. Project of Tauragè hospital, 1931 (Lithuanian Central State Archive)

emerged as common design elements, which "became an integral part of clean lines of modernism and were seen as a means of treating patients" (Willis et al. 2019, 178). The building was divided into two functional zones. The main corps was dedicated to treatment and the other part to the wards. Mechanization of the building was also implemented - it had ventilation and central heating systems, elevators for people and food supply - accents that were supposed to facilitate the functioning of the building.

\section{GROWING INFLUENCE OF MODERNISM IN HOSPITAL ARCHITECTURE IN THE SECOND HALF OF THE 1930s}

By the mid-1930s, the influence of modernism on Lithuanian architecture was obvious. Many new buildings were designed with a modern look, as Lithuanian architects at that time, according to architect A. Šalkauskis, were interested in the latest "architectural trend", which was modernism 
(Šalkauskis 1935, 266). Some studied in the Western countries or visited them to get acquainted with the latest architectural achievements, and applied the acquired experience in the design of various buildings, including hospitals. Thus, the fact that modernism influenced the evolution of hospital architecture is related to the overall spread of this style in Lithuania, which manifested itself in various types of buildings. Furthermore, in the context of hospitals, the architecture of such buildings during this period began to be considered a significant factor in their modernization. It was noticed that "the building itself with its beautiful, aesthetic lines, cozy, harmonious appearance" should serve to create the image of a modern institution and treat patients - for example, be well-lit, well-planned, meet the latest medical requirements and correspond to the latest architectural trends (Tallat-Kelpša 1935, 26).

Also, to encourage municipalities to modernize hospitals, in the mid1930s "Hospital Management Rules" had been approved by the state government. They stipulated, for example, that "all patient rooms must be adequately heated, ventilated and lit". The need to separate auxiliary rooms from those intended for treatment was stressed, as well as space requirements for the patient wards were specified (no less than $7.5 \mathrm{~m}^{2}$ for each patient), since in some hospitals, the patients, were usually cramped due the lack of space (Vyriausybės žinios 1936, 9). The study found that these rules led to greater changes inside the buildings, while their exterior-specific requirements were not applied, and the buildings were designed according to the stylistic intentions of their designers.

For example, the growing influence of modernism and overall modernization was reflected in the new buildings of Kedainiai (arch. J. Dačinskas), Alytus (arch. S. Taškūnas) and Seinai (Lazdijai) municipality hospitals (arch. K. Garmus). They were designed in 1935-1937 in modern style, which by then had also become a creative trend of their designers. It is known that around the same time J. Dačinskas, S. Taškūnas, K. Garmus were designing other buildings, such as private houses and schools, their design influenced by modernism. Consequently, the new hospital buildings in these municipalities had typical design features of modernism - smooth shapes, calm, ascetic appearance, lack of decorative elements and large open spaces (Figure 3). These were seen not only as a stylish trend, but also as accents to serve the needs of the patients, as balconies and loggias were intended to be "used for sunbathing and relaxation" (Dačinskas 1937, 377). The premises of these buildings in an irregular corner plan were divided according to their function because this was one of the requirements, which was probably influenced by the plan of the earlier hospital in Tauragè. For example, the design rules for the new hospital in Alytus stated that the building and its plan "must be clear, without many curved, 


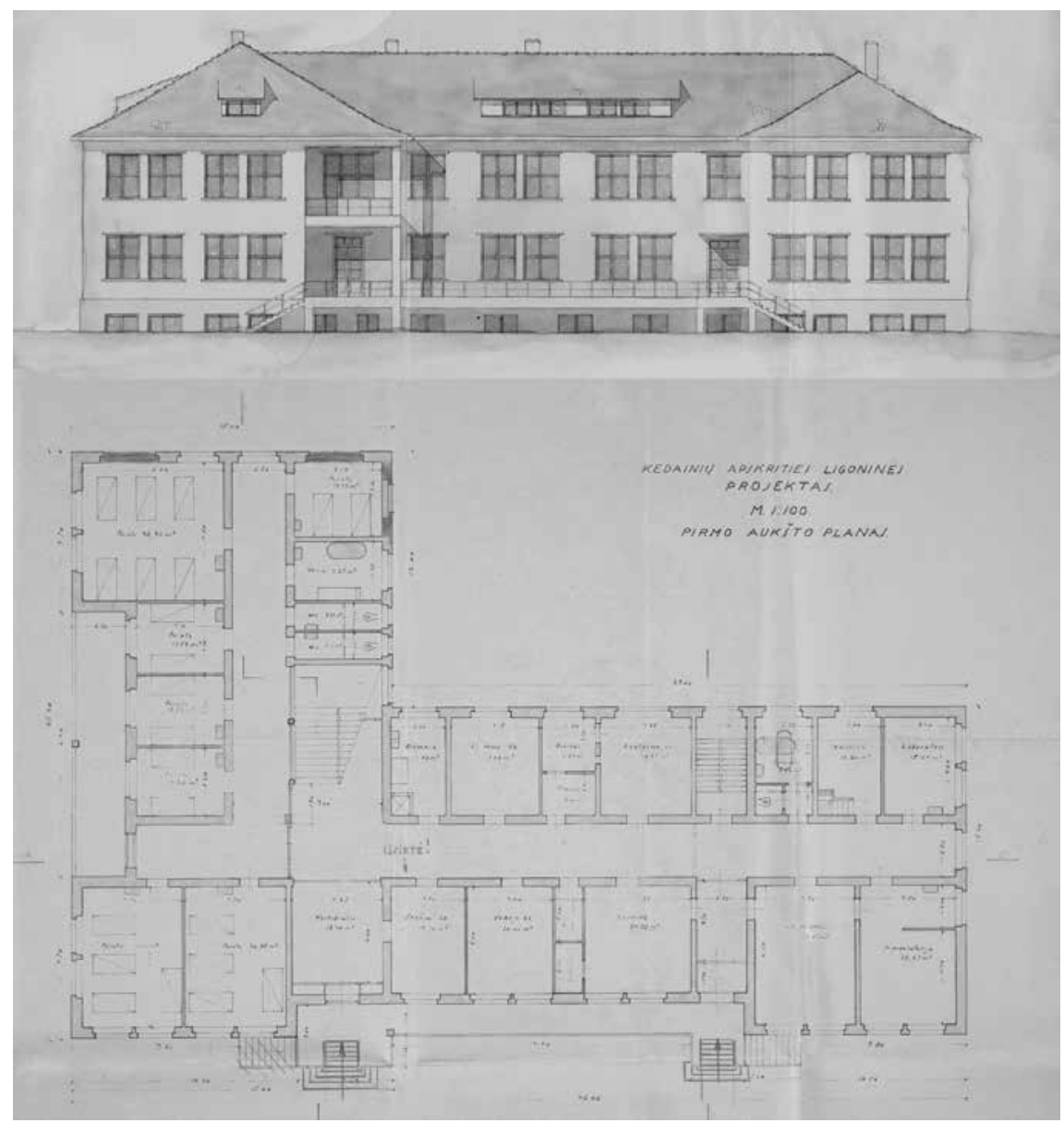

Figure 3. Project of Kèdainiai hospital, 1935 (Lithuanian Central State Archive)

angled corridors and have the most comfortable shape possible without complex constructions" (LCVA, 1567-3-396, 168). The desire to provide comfort to patients was also expressed, as the patient rooms were spacious, and most had only two beds. The efficiency of the buildings was ensured by mechanization. Ventilation, food elevators, water supply, boiler rooms were installed. The study found that these were one of the most modern hospitals in Lithuania in their time, where the newest architectural trend was successfully combined with the comprehensive modernization.

Despite being influential, ascetic modernist aesthetic was not the only stylistic trend in Lithuanian hospital and overall architecture in the 1930s. While some architects thought that the architecture must change according to times, and therefore it was only natural to design buildings in modernist, "western" style (VRVA, 1171-2-78, 23), there were also others who were 


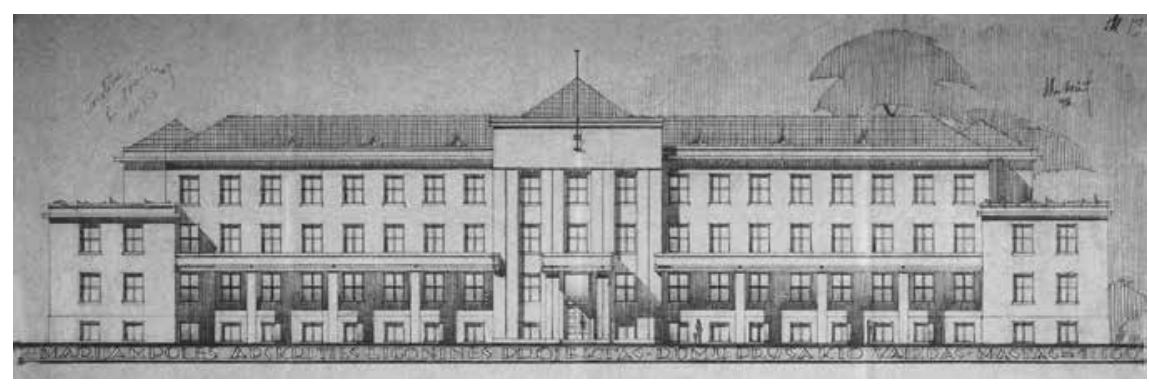

Figure 4. Project of Marijampolè hospital, 1936 (Lithuanian Central State Archive)

of the opinion that if the building fully met the functional requirements, the exterior could be designed regardless of the latest stylistic trends and "the dispute over the primacy of classicism, romanticism, or modernism must be secondary; first of all, attention must be paid to the immediate tasks of the building" (Bielinskis 1939, 126).

An example of this is the new Marijampole Municipality hospital (arch. A. Lukošaitis) designed in 1936 (Figure 4). Comparing this building with other analogues, the elements of classical architecture, such as simplified pilasters, profiled cornices, have appeared on its exterior. Thus, the building had a less modern look than the other analogues. Nevertheless, the exterior of the building contained an advanced modern medical facility. The long part of the building, which housed all the wards, had balconies and terraces for the convenience of the patients. Like other hospitals, this one incorporated many innovations that were not present in the old tsarist hospital building - elevators, modern operating room, heating systems, the latest treatment equipment (LCVA, 1361-1-447, 1). A similar path was followed in designing the new Mažeikiai hospital building in 1937. Here, arches of various sizes were used in the entrance part, and a colonnade motif was inserted in the curved part of the façade, where the loggias were placed. As a result, the building acquired a slight hint of classical architecture, but was designed with the latest medical advances inside.

The study found that despite the design of several conservative-looking hospital buildings, modernism continued to influence the architecture of such buildings in the late 1930s. Examples of this are the new buildings designed in 1938 for municipality hospitals in Telšiai (arch. S. Stulginskis) and Raseiniai (arch. A. Adamonis). The exterior of these buildings was designed with the typical modernist aesthetics - divided by rows of windows, smooth, minimalistic walls without excess decorations, emphasized by central open spaces. For example, an important external element in the new Telšiai hospital (Figure 5), was the central loggia and in the new Raseiniai 


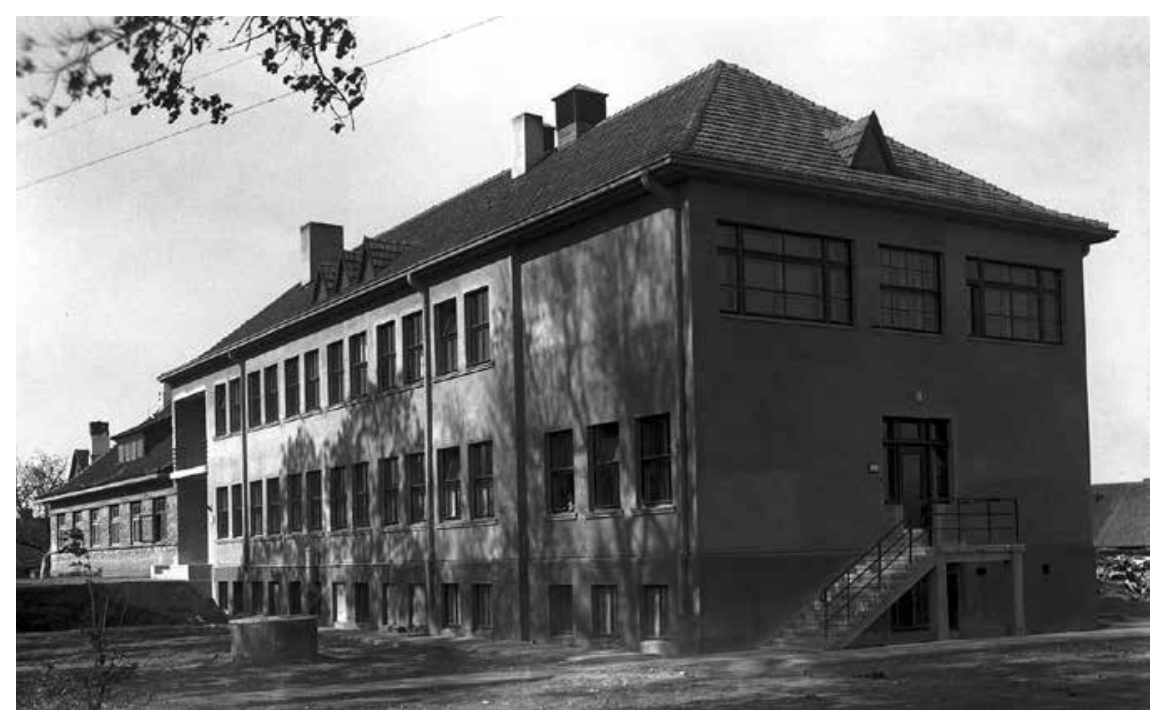

Figure 5. New building of Telšiai hospital, 1940s (Samogitian museum “Alka”)

hospital - its large balconies. It was not only an additional place for sun treatment and fresh air for the patients, but also an integral part of the overall appearance of the buildings. Thus, by giving up excessive decorativeness, these buildings symbolize the influence of functionality and modernity that shaped such buildings of the era. It can be said that modernist aesthetics in these buildings was creative intentions of their designers. For example, S. Stulginskis was thought to be "a very talented modernist architect", who, in addition to the new hospital, designed other modernist looking public buildings in Telšiai - gymnasium, "Alka" museum building, which was thought to be "very beautiful" (Architektas Stulginskis išvyko i Šiaulius 1938, 4). Because of their design and internal modernization, which consisted of contemporary equipment, these buildings were seen by contemporaries as "the most modern" specimens of such type in Lithuania (Milènas 1938, 8).

\section{CONCLUSIONS}

To sum up, it is worth emphasizing that the analysed examples of hospital buildings designed in various towns of Lithuania show that in the interwar period such buildings underwent significant changes. These changes took place not only on the outside, but also on the inside. Even though the first hospital buildings began to be built in the 1920s, major changes in such buildings began in the 1930s. At that time, new stylistic 
trends in hospital architecture emerged quite early, but the main aim until mid-1930s was to transform and modernize hospitals primarily internally rather than externally. That was to be done by applying new principles of planning, functional zoning, providing the latest treatment equipment, and so on. As a result, in the early 1930s, only few new hospital buildings reflected stylistic innovations.

The study found that a major stylistic break in hospital architecture began in the mid-1930s when the design of new hospital buildings that responded to the latest architectural trends externally and to the latest medical requirements internally commenced in several Lithuanian municipalities. Essential features of such buildings became balconies, terraces and loggias, wide windows, minimalist forms, undecorated, simple façades, giving meaning to the ideas of the modernism, as well as the desire to adapt the buildings not only internally but also externally for optimal treatment.

To conclude, it can be said that in the 1930s, the new Lithuanian hospitals underwent the most important transformations, and the influence of modernism in their architecture, while not universally adapted, changed the appearance of the buildings. Therefore, the spread of modernism in the architecture of hospital buildings can also be perceived as a natural consequence of changing ideals in architecture and the modernization of hospitals when progressive external aesthetics, which was widely applied in architecture at the time, could also respond to a progressive medical institution inside. Thus, the study found that the evolution of hospital architecture during the Interwar Lithuania was shaped by two major factors the changing ideals in overall architecture and the increased requirements for hospital modernization.

\section{REFERENCES}

1935 m. gruodžio mèn. Bendrais technikiniais reikalais susirašinèjimas. Lithuanian Central State Archive (Vilnius, LCVA), 377-1-169, 72 p.

Apie statybą ligoninei namų Šiauliuose bendrai su Šiaulių miesto savivaldybe. Lithuanian Central State Archive (Vilnius, LCVA), 862-1-2649, 20, 98 p.

Architektas Stulginskis išvyko į Šiaulius, 1938. Vakarai, 233 (839), 4.

Bielinskis, F., 1939. Mūsų miestų architektūra ir civilizacija. Technika ir ūkis, 6 (33), 126.

Dačinskas, J., 1937. Nauja Kėdainių apskrities savivaldybės ligoninė. Savivaldybè, 12 (35), 377-380.

Inžinieriaus Vytauto Peldavičiaus ir architekto Vladimiro Zubovo laiškai. Vilnius Regional State Archive (Vilnius, VRVA), 1171-2-78, 23 p.

Kèdainių m. ir apskr. ligoninès patvirtintas projektas. Lithuanian Central State Archive (Vilnius, LCVA), 1622-4-478, 10 p.

Kilinskaitè, R., 2013. Respublikinè Klaipėdos ligoninè, 2013. Available at: http://www. autc.lt/lt/architekturos-objektai/1309 [accessed 01.11.2020.] 
Ligoninès statymo reikalu. Lithuanian Central State Archive (Vilnius, LCVA), 1567-3-396, $168 \mathrm{p}$.

Ligoninių santvarkos taisyklès, 1936. Vyriausybès žinios, 520, 7-10.

Marijampolès apskr. ligoninès patvirtintas projektas. Lithuanian Central State Archive (Vilnius, LCVA), 1622-4-686, 12 p.

Meškauskas, J., 1987. Lietuvos medicinos istorija. Čikaga: Draugo spaustuvè.

Milènas, J., 1938. Raseiniai keičia savo veidą... Lietuvos žinios, 251 (5817), 8.

Pasiūlymas dèl medicininių aparatų ịrengimo ligoninèje. Lithuanian Central State Archive (Vilnius, LCVA), 1361-1-447, 1 p.

Šalkauskis, A., 1935. Lietuvių architektūros raida. Naujoji Romuva, 10-11 (218-219), 266.

Šiaulių miesto ir apskrities ligoninè. Vilnius Regional State Archive (Vilnius, VRVA), 1171-1-255, 1 p.

Šimulytè, A., 2007. Profesionalumas, grožis - sveikam ir ligos pakirstam. XX a. 4 dešimtmečio ligoninès Žemaitijoje. Žemaičiu žemè, 3, 2-3.

Sniegulis, 1937. Savivaldybių ligoninių statyba. Savivaldybè, 12 (35), 373-376.

Sniegulis, 1938. Savivaldybių ligoninių statyba. Lietuvos aidas, 5 (3314), 6.

Tallat-Kelpša, F., 1932. Dèl medicinos reikalų sutvarkymo Lietuvoj. Savivaldybė, 9 (112), 4-6.

Tallat-Kelpša, F., 1932. Dèl str. "Savivaldybių ligoninès". Savivaldybè, 6 (109), 12-15.

Tallat-Kelpša, F., 1935. Ligoninès statyba, įrengimas ir ligonio psichika. Savivaldybè, 5, 26-28.

Tauragès apskr. savivaldybès ligoninès patvirtintas projektas. Lithuanian Central State Archive (Vilnius, LCVA), 1622-4-149, 7-8 p.

Willis, J., Goad, P., Logan, C., 2019. Architecture and Modern Hospital. Nosokomeion to Hygea. London: Routledge. 


\title{
SLIMNĪCU ARHITEKTŪRAS ATTĪSTĪBA STARPKARU LIETUVĀ
}

\author{
ĖVALDS VILKONČUS
}

Vītauta Dižā Universitātes (Kauṇa) doktorants

E-pasts: evaldas.vilkoncius@vdu.lt

\section{ANOTĀCIJA}

1918. gadā Lietuvai atkal kḷūstot par neatkarīgu valsti, daudzas slimnīcas darbojās nepiemērotās telpās, un tādēl pilsētās tika uzcelts daudz modernu slimnīcu ēku. Joprojām nav pētītas pārmainas Lietuvas starpkaru posma slimnīcu arhitektūrā. Rakstā aplūkota slimnīcu ēku arhitektūras attīstība Lietuvā starpkaru periodā.

Atslēgas vārdi: modernā arhitektūra, slimnīca, Lietuvas arhitektūra, slimnīcu ēku arhitektūra.

\section{KOPSAVILKUMS}

Rakstā analizēta aktuāla, bet līdz šim maz pētīta tēma - jauno valsts slimnīcu ēku attīstība starpkaru Lietuvā (1918-1940). Lielākā daḷa slimnīcu tolaik jaunajā valstī darbojās nepiemērotās ēkās, tāpēc dažādās pilsētās bija jāuzbūvē daudzas jaunas, modernas ēkas slimnīcu vajadzībām. Rakstā apskatītas šì perioda galveno jauno Lietuvas slimnīcu dizaina īpatnības un attīstība. Uzskatāms, ka tajā laikā notikušās ārējās un iekšējās izmaiņas būtiski ietekmēja Lietuvas slimnīcu arhitektūras attīstību, tādēḷ tās var uzskatìt par nozīmīgiem, lai arī mazpazīstamiem Lietuvas starpkaru arhitektūras paraugiem. 


\title{
ZVIEDRU KARASPĒKA APGĀDE VIDZEMË 1700. GADA NOGALË UN 1701. GADA PIRMAJĀ PUSĒ
}

\author{
MIKUS ŽAGATA
}

Mg. hist.

\begin{abstract}
ANOTĀCIJA
Rakstā apskatīta Vidzemes provinces (Liuland) lokālās un Zviedrijas karalistes centrālās administrācijas veiktie organizatoriskie pasākumi provincē izvietoto bruṇoto vienību apgādei ar nepieciešamajiem resursiem kaujas spēju nodrošināšanai 1700. gada nogalē un 1701. gada pirmajā pusē. Pētijumā tika noskaidrots, ka zviedru armijas uzturēšana šajā laika posmā sākumā bija sarežğīta un negatīvi ietekmēja visas provinces ekonomisko situāciju. Tas liek kritiski pārvērtēt zaudējumu apjomu, kuru 1701. gada otrās puses un 1702. gada sirojumu laikā bija spējīgs nodarīt krievu karaspēks, par ko tik ḷoti savā vēstulē Pēterim I lielījās grāfs Šeremetjevs.
\end{abstract}

Atslēgas vārdi: Lielais Ziemeḷu karš, Ēriks Dālbergs, Kārlis XII, zviedru Vidzemes province.

\section{IEVADS}

Latvijas jauno laiku vēstures pētnieku ir maz, un attiecīgi tā laika notikumi, to skaitā Lielais Ziemel̦u karš, Latvijas historiogrāfijā ir relatīvi maz izpētīiti. Pētnieki, kuri ir tieši vai pastarpināti pievērsušies padziḷinātai 17. gadsimta beigu un 18. gadsimta sākuma izpētei, ir Edgars Dunsdorfs, kurš mūža lielāko daḷu strādāja trimdā (piemēram, Dunsdorfs 1962), Marta Āboliṇa, kura pētījusi zemnieku dzīvi Vidzemē 17. un 18. gadsimtā, bet rakstījusi arī tieši par Lielo Ziemel̦u karu, un Mārìte Jakovḷeva, kura Lielo Ziemeḷu karu pētijusi caur Kurzemes un Zemgales hercogistes prizmu (Jakovḷeva 2003; Jakovḷeva 2007). Ka interese par Lielo Ziemeḷu karu 
sabiedrībā ir, parāda tas, ka Arnis Kohs Jumītis 2018. gadā izdevis uniformolog̣ijas žanram veltītu grāmatu "Zem Kārḷa XII karogiem. Latviešu karavīri 18. gadsimta Zviedrijas armijā" (Kohs Jumītis 2018). Salīdzinot ar kaimiņvalstīm, Latvijā šim notikumam nav veltītas monogrāfijas un attiecīgi kopējā izpratne par Lielā Ziemeḷu kara notikumiem ir sliktāka. Piemēram, Igaunijā, kur vēsturnieki Marguss Laidre (Laidre 1996) vai Heldurs Palli (Palli 1966) 20. gadsimta otrajā pusē un 21. gadsimta sākumā šim periodam ir veltījuši pat monogrāfijas, tēmas izpratne ir augstākā līmenī.

İpaši zīmīgi tas šḳiet, jo 2021. gadā aprit 300 gadu kopš oficiālā Lielā Ziemeḷu kara miera līguma Ništatē noslēgšanas un Vidzemes, visas Igaunijas, Ingrijas un Vīborgas lēna de iure pāriešanu Krievijas caristes īpašumā. Atzīmējot šo vēstures pagrieziena punktu, būtu svarīgi izprast notikumus, kas noveda pie šāda iznākuma.

Tātad Lielā Ziemeḷu kara notikumu padziḷināta izpēte apmierinās sabiedrības interesi par Lielā Ziemel̦u kara vēsturi un veicinās Latvijas Jauno laiku historiogrāfijas vēstures pētniecību šajā specifiskajā jomā, nodrošinot, ka uz vienu no Latvijas vēstures pagrieziena punktiem tā trīssimtgadē mēs kopumā varam paskatīties izglītotāki un zinošāki.

Šì raksta objekts ir zviedru administrācijas organizētās darbības Vidzemē (un Igaunijā) stacionētā karaspēka nodrošināšanai ar resursiem, bet uzdevumi savukārt ir:

1) identificēt resursus, ar kuriem zviedru administrācija vēlējās nodrošināt karaspēku;

2) izpētīt, kā šie resursi tika sagādāti;

3) noskaidrot, kādas bija problēmas un sarežǵgijumi resursu sagādē;

4) izprast, kādu ietekmi tas atstāja uz Vidzemes ekonomisko situāciju.

Pētijums ir balstīts uz līdz šim Latvijas historiogrāfijā maz izmantoto Latvijas Valsts vēstures arhīvā glabāto Vidzemes (zviedru) Ģenerālgubernatora kancelejas fondu un tā sastāvā esošajām lietām no Vidzemes ǵenerālgubernatora Ērika Dālberga sarakstes ar Zviedrijas karali Kārli XII, Vidzemes fogtiem, Igaunijas ekonomiskā novada pārvaldnieku Gustavu Ādolfu Stromfeldu, kā arī Kara kolēǵijas un Kara komisariāta lietas. Jāatzīmē, ka šos materiālus autors izmantojis 2012. gadā LU Vēstures un filozofijas fakultātē aizstāvētā maǵistra darba sagatavošanai.

\section{ZVIEDRU ARMIJAS APGĀDE 1700. GADA SEPTEMBRĪ-OKTOBRĪ}

Lielo Ziemeḷu karu ar neveiksmīgu pārsteiguma uzbrukumu Rīgai no Zemgales 1700. gada 11. februārī iesāka Augusta II Stiprā sakšu spēki. Nedaudz vēlāk savā pierobežā karadarbībā iesaistījās arī Dānija. Kamēr 
zviedru karalistes pamatarmija no Zviedrijas tika mobilizēta karagājienam un veica karadarbību Dānijā, sakšu spēkiem bija aptuveni sešus mēnešus ilgs pārspēka periods Rīgas pievārtē. Lai gan sakšu karaspēkam izdevās ieņemt Kobronskansta un Daugavgrīvas cietoksni, kā arī pārcelties pār Daugavu, tomēr Rīgu ieṇemt tiem tā arī neizdevās. Vēlāk rudenī karā pret Zviedrijas karalisti iesaistîjās arī Pēteris I, ar savu armiju aplencot Narvas cietoksni zviedru Igaunijas provincē.

1700. gada rudenī Vidzemē bija izveidojusies šāda situācija - zviedriem Rīgā atradās aptuveni 3500 visu ieroču škiru karavīru liels garnizons (Höglund, Sallnäs 2000, sid. 67, 79, 106), Rūjienā atradās aptuveni 3500 kājnieku un kavalēristu lielais generāḷa Oto Velinga komandētais korpuss (Laidre 1996, sid. 85-86, 138), Valkas apkārtnē tika formētas pulkveža Volmāra Antona fon Šlipenbaha vienības, kuru izmēru varētu vērtēt uz vairākiem simtiem karavīru, Tērbatas garnizonā - aptuveni 1000 karavīru, Pērnavā - aptuveni 600 karavīru, kā arī formēšanas stadijā esošās vienības Sāmsalā, kuru skaitliskais sastāvs varētu būt daži simti karavīru (Palli 1966, c. 56-66). Kopā pa visu Vidzemes latviešu un igauņu dą̧u zviedru administrācijas rīcībā bija aptuveni 9000 karavīru liels karaspēks. Sakšu karaspēks šajā laikā lielākoties bija devies uz savām ziemas mìtnēm, un tā precīzu skaitlisko sastāvu noteikt ir sarežğîti. 1700. gada pavasarī sakšu karaspēka izmērs bija vērtējams uz 14000 karavīru, bet Rìgas aplenkumā 1700. gada vasaras beigās tas varētu būt bijis pat 22000 karavīru (Wimmer 1956, 52-53). Tomēr faktiski šajā laikā pie Kokneses, Kobrona un Daugavgrīvas nocietinājumos atradās vien vairāki tūkstoši karavīru. Pārējās vienības pēc neveiksmīgā Rīgas aplenkuma bija devušãs ziemas mitekḷos Kurzemes iekšienē un Lietuvā.

1700. gada augustā Zviedrijas karalis Kārlis XII uzdeva Vidzemes generālgubernatoram Ērikam Dālbergam veidot armijas magazīnas (noliktavas) ar visu nepieciešamo kā cilvēkiem, tā zirgiem, lai no Zviedrijas un Somijas nākošajiem spēkiem pietiktu uztura līdz maijam. Lai gan uzdevums tika dots augusta vidū, Rīgā generālgubernators to saņēma tikai pēc mēneša un faktisko sagatavošanos karaļa armijas uzņemšanai sāka tikai 1700. gada septembra vidū (Latvijas Nacionālā arhīva Latvijas Valsts vēstures arhīvs (turpmāk LNA-LVVA), 7349-1-72, 454, 469). Drīz vien tika secināts, ka Vidzemes latviešu apdzìvotā daļa kara dēl lielā mērā ir izpostīta un būs sarežǵîti vai neiespējami no tās gūt resursus karaspēka uzturēšanas noliktavu aizpildǐšanai. Proti, Vidzemes dienvidu dạ̧u bija izpostījis un izlaupījis sakšu karaspēks, savukārt latviešu apdzīvotās Vidzemes ziemeḷu daḷu līdz Gaujai bija iztukšojis tur pa vasaru stacionētais zviedru karaspēks (LNALVVA, 7349-72, 464, 467).

Lai izpildītu karaļa uzdevumu, Vidzemes generālgubernators aizliedza pārtikas izvešanu no Vidzemes provinces uz Igaunijas provinci, kā arī lūdza 
turienes ǵgenerālgubernatoram nepien,emt labību, kas tiek vesta no Vidzemes, kā arī lūdza palīdzēt magazīnu izveidei ar provianta pievedumiem. Līdzīgs plāns bija padomā arī attiecībā uz Ingrijas provinci (LNA-LVVA, 7349-1-72, 462, 467). Savukārt Vidzemes provinces līmenī igauṇu ekonomiskā apgabala pārvaldniekam tika uzdots ieņemt pēc iespējas pilnīgāku īri no muižu īrniekiem, noalgot darbiniekus magazīnu apkalpošanai, kā arī sākt faktisko magazinnu piepildī̌̌anu ar proviantu un furāžu. Magazīnas bija plānotas Tērbatā, Pērnavā, Viljandi un Peltsamā. Kā izrādījās, kamēr Vidzemes ǵenerālgubernators bija bloḳēts Rīgā, igauņu ekonomiskā apgabala pārvaldnieks jau bija licis rezervēt ievērojamu apjomu provianta un furāžas no viņam pakḷautajiem apriņ̧̧iem un daḷa jau bija savākta magazinnās vai arī nogādāta zviedru karaspēka nometnē Rūjienā. Latviešu ekonomiskajā apgabalā attiecīgas pavēles izpildei izdeva Rūjienā esošā zviedru karaspēka komandieris ǵenerālis Vellings (LNA-LVVA, 7349-1-72, 473-475; 7349-1320, 30-34, 36-37).

Lai gan sākotnēji šīs magazīnas tika veidotas, pieņemot, ka Kārlis XII ar armiju virzīsies pretī sakšu armijai, kas bloḳēja Rīgu, tomēr, tā kā pilsētas blokāde tika non,emta un sakšu armija devusies uz ziemas nometnes vietām, tad zviedru armija tika vērsta pret Narvas pilsētu aplencošo krievu karaspēku. Tāpēc oktobra beigās Vidzemes provinces magazīnās savāktie resursi bija jāpārved uz Rakveres pilsētu Igaunijas provincē karaḷa armijas vajadzībām un tajās pašās magazīnās jāuzsāk resursu uzkrāšana 1701. gada zviedru armijas kampan,ai (LNA-LVVA, 7349-1-72, 623-624, 659-663).

\section{ZVIEDRU ARMIJAS APGĀDES SAGATAVOŠANA 1701. GADA KAMPAṆAI}

Pēc uzvaras pār Pētera I karaspēku pie Narvas novembra beigās, kad kḷuva skaidrs, ka zviedru armija savu ceḷu turpinās pret sakšu karaspēku, Vidzemes ǵnenālgubernators uzdeva abiem Vidzemes ekonomisko apgabalu pārvaldniekiem personīgi nodrošināt magazīnu atkārtotu piepildīšanu ar proviantu un furāžu. Magazīnas paredzēja veidot iepriekšējās lokācijās, kā arī jaunās vietās - Laisā, Kirepi un Valmierā. Jau decembrī Igaunijas ekonomiskā apgabala pārvaldnieks Stromfelds brīdināja ǵgenerālgubernatoru, ka varētu rasties problēmas ar provianta un furāžas ievākšanu provinces austrumu pierobežā, kuru sistemātiski postīja krievu iebrukumi (LNALVVA, 7349-1-320, 71-75).

Tā, piemēram, nokḷuvusi ziemas nometnē pie Laisas, Kārḷa XII armija patiesi sākotnēji izjuta pārtikas trūkumu, jo magazīnu nebija izdevies piepildìt ar nepieciešamajiem resursiem (Karolinska krigares dagböcker jämte andra samtida skrifter (1903). II. Lund: Gleerup, 125. lpp.). Drīz pēc tam 
Stromfelds atzina, ka nu jau arī Igauņu ekonomiskajā apgabalā ir grūtības ar resursu sagādi magazīnu piepildīšanai, un rekomendēja pieprasīt privātmuižām pret atlīdzību atdot visus resursus, kas tām nebija nepieciešami pavasara sējai un uzturam, ko generālgubernators arī apsolījās izdarìt, izdodot attiecīgu patentu. Savukārt karaḷa administrācija jau 1701. gada janvārī aizliedza vest pārtiku no laukiem uz pilsētām un pieprasijja armijai paredzētos resursus no muižām nogādāt magazīnās (LNA-LVVA 7349-1-321, 59-61; 7349-1-73, 30-31, 37-38; 7348-1-150, 43-44). Aizliegums no laukiem ievest pilsētās pārtiku jau marta beigās radīja problēmas Rīgā, jo apiņu trūkuma dẹl Rīgā nebija iespējams nodrošināt ikdienas dzēriena alus brūvēšanu, bet pilsētas garnizona pastiprināšanai paredzēto vienību generālgubernators lūdza Kārlim XII aț̣auju kādu laiku vēl atstāt laukos, kur tai būtu pietiekams uzturs. Savukārt aprị̣̄a beigās piegāžu pārtraukuma dēḷ Rīgas garnizonā sāka izsîkt mieži un iesals (LNA-LVVA, 7349-1-150, 170172). Kopumā magazīnas tomēr izdevās piepildīt ar nepieciešamo pārtiku un proviantu. To ilustrē generālgubernatora sarakste ar kara generālkomisāru 1701. gada aprị̣̂a beigās, kurā generālgubernators vērtēja, ka iespēju robežās Valmieras magazīna ir piepildīta ar maizi, miltiem, zirņiem, putraimiem, kā arī sienu un auzām zirgiem (LNA-LVVA, 7349-1-73, 342345). Sliktāka situācija bija Rīgā - generālgubernators sarakstē ar karali atvainojās par nožēlojamo stāvokli garnizonā, bet norādīja, ka 15 mēnešu ilgo ienaidnieka sirojumu un armiju uzturēšanas dēl resursi ir beigušies un, ja pārtika netiks pilsētai atsevišķi pievesta, karaļa armijai, ierodoties pie Rīgas, būs jāpaḷaujas tikai uz Dievu (LNA-LVVA, 7349-1-73, 476-479).

Jūnija sākumā, pirms zviedru armija devās ceḷā uz Rīgu no ziemas nometnēm pie Tērbatas, Kārlis XII informēja Vidzemes generālgubernatoru, ka no Tallinas uz Rīgu pa jūru tiks nogādāti pārtikas krājumi, bet jūnija beigās pārtika ar kuğiem tika sūtìta arī no Pērnavas magazīnām. Pirmie kug̣i ar proviantu ieradās jūnija beigās. Tā kā atsūtītais daudzums bija milzìgs, bet kug̣i tika izkrauti Vecāḳos, krāvēju un laivu skaits bija ierobežots un pa sliktā stāvoklī esošiem zemes ceḷiem kravas vēl bija jānogādā uz Rīgu, tas ritēja lēni. Vēl nedēḷu pēc Spilves kaujas, kad Kārḷa XII armija jau atradās Kurzemes un Zemgales hercogistes teritorijā, visi kuği vēl nebija izkrauti (LNA-LVVA, 7349-1-150, 454-455; 7349-1-73, 518, 567-568, 618-619).

\section{ZVIEDRU ARMIJAS APGĀDES FAKTISKĀ NODROŠINĀŠANA 1701. GADA JŪNIJĀ MARŠA UZ RĪGU LAIKĀ}

Kārla XII armija no Tērbatas uz Rīgu devās ceḷā 15. jūnijā. Jau drīz parādījās pirmās problēmas. 25. jūnijā karalis rakstijja Dālbergam, norādot, ka šḳūtis, īpaši latviešu ekonomiskajā novadā, netiekot veiktas pietiekami 
ātri, jo tikko izveidoto zemessargu bataljonu virsnieki savus zemniekus bija sasaukuši uz sapulcēm. Tādēḷ karalis Dālbergam pavēlēja nokārtot, lai šādas sapulces netraucētu šķūšu darbus, ko Dālbergs realizēja, izdodot patentu. Pats latviešu ekonomiskā novada pārvaldnieks Strokirks problēmu ar šķūtìm gan saistijja ar daudzajiem papildu aizkomandējumiem provincē. Piemēram, 1000 ratu bija nosūtīti uz Pērnavu, kurus būtu bijis iespējams izmantot šķūtīm karạ̣a armijas vajadzībām. Dažas dienas vēlāk Kārlis XII uzdeva organizēt, lai armijai no Rīgas būtu iespējams papildus piegādāt nepieciešamos resursus, jo līdzi paņemtie resursi tuvojās izsīkumam. Taču Rīgā šo pavēli izpildīt bija sarežğîti, jo problēmas radīja vēja trūkums miltu malšanai un malkas trūkums maizes krāšņu kurināšanai (LNA-LVVA, 73491-73, 571-572).

Zviedru karaspēks Rīgas pievārtē nonāca 1701. gada 7. jūlijā. Nedaudz atpūties un sagaidījis labvēlīgus laika apstākḷus, tas 9. jūlijā desantējās Daugavas kreisajā krastā un Spilves kaujā sakāva poḷu-sakšu-krievu apvienoto armiju. Spilves kaujas rezultātā zviedru armija sagrāba lielāko daļu resursu, kurus ienaidnieki bija atstājuši nometnēs un noliktavās Pārdaugavā. Pēc Spilves kaujas zviedru karaspēks dažādus resursus, tajā skaitā proviantu, ieguva arī Jelgavā, Engurē un Slokā (LNA-LVVA, 7349-1-73, 602, 610611, 621; 7349-1-338, 47; Jakovḷeva 2007, 46-47).

\section{SECINĀJUMI}

Tātad zviedru armija 1700. gada rudenī ieradās daḷēji iztukšotā Vidzemes provincē. Tomēr, cīîigi ievācot resursus no valsts muižām un ierobežojot to nonākšanu pilsētās, visā Vidzemē izdevās iegūt nepieciešamo gan armijas apgādei Igaunijas provincē līdz Narvas kaujai, gan uzturoties ziemas mītnēs Vidzemes teritorijā. Tomēr, gatavojoties 1701. gada kampaņai, kurai bija jānorit ienaidnieka postītajā Vidzemes provinces dienvidu dạ̦ā, kur karadarbība notika jau kopš 1700. gada februāra, bija nepieciešams jau organizēt resursu papildu pievešanu arī, piemēram, no Igaunijas provinces. Šajā laikā ar dažāau armijai nepieciešamo resursu iegūšanas problemātiku saskārās nu jau ne tikai sakšu karaspēka postītās Vidzemes dienvidu teritorijas, bet arī nepostītās ziemel,u teritorijas. Lai gan Kārḷa XII armija pēc Spilves kaujas devās tālāk Kurzemes-Zemgales hercogistes teritorijā un Vidzemes provincei pamatarmija vairs nebija jānodrošina, tomēr provinces resursi, vairāk nekā devinuus mēnešus uzturot Zviedrijas pamatarmiju, bija noplicināti. Šādā situācijā 1701. gadā tika formēti rakstā pieminētie latviešu un igauṇu zemnieku militārie bataljoni, tāpat robežu pret Krieviju aizsardzībai tika organizētas arī vairākas citas papildu vienības. Arī tās bija jānodrošina ar Vidzemes provinces resursiem. Lai gan tas neietilpst šajā 
pētījumā, tomēr ir vērts atzīmēt, ka bija problēmas ar vienību nokomplektēšanu ar karavīriem un dažādiem ikdienā nepieciešamajiem resursiem. Šādai apgādes situācijai, visticamāk, bija arī tieša cēloṇsakarība ar provinces apsardzībai atstāto spēku militārajām neveiksmēm 1702. gadā un vēlāk.

Un nobeigumā - tikai pēc gada 1702. gadā Krievijas feldmaršals Šeremetjevs Pēterim I ziņoja: "Ienaidnieka zemē vairs nav ko postīt. No Pleskavas līdz Tērbatai, lejup pa Velikajas upi, gar Peipusa ezera krastiem līdz Narvas upes grīvai, ap Tērbatu, aiz Tērbatas [..] Laiuses līdz Rēvelei, 50 verstis pret Rakveri un tālāk no Tērbatas uz augšu pa Mētraines upi līdz Vircezeram, pret Helmi un Karksi, un aiz Karksi līdz 38 verstīm pret Pērnavu, un no Rīgas līdz Valkai: viss ir nopostìts, pilis ir uzspridzinātas. Nekas vairs nav saglabājies bez Pērnavas un Rēveles, un šur tur kāda muiža jūrmalā. Citādi viss starp Rēveli un Rīgu ir izravēts. Apdzīvotās vietas atrodamas tikai uz kartes." Ja zinām, ka jau pēc zviedru karaspēka uzturēšanās Vidzemē 1700.-1701. gadā provincē bija noplicināta resursu bāze, šì Šeremetjeva atskaite iegūst citu perspektīvu. Jā, visticamāk, Vidzemes provincē sirojošajam krievu karaspēkam patiesi izdevās iznīcināt cietokšnus, nodedzināt apdzīvotās vietas un aizvest gūstā Vidzemes provinces iedzīvotājus, bet jādomā, ka viṇu laupījums nebija tik l,oti ievērojams, kā varētu šķist no šìs Šeremetjeva vēstules Pēterim I. Savukārt vēsturniekiem ir sev jāuzdod jautājums - vai šāda līmeņa resursu noplicināšana Vidzemes provincē no zviedru administrācijas puses patiešām atbilst vēstures literatūrā 20. gadsimtā nereti veidotajam stāstam par labajiem zviedru laikiem Latvijas vēsturē. Vismaz šĩs epizodes kontekstā autoram šādu apgalvojumu nebūtu vēlme apstiprināt.

\section{IZMANTOTO AVOTU UN LITERATŨRAS SARAKSTS NEPUBLICÉTIE AVOTI}

LNA-LVVA, 7349-1-72, Izejošo rakstu kopiju žurnāls, 1700.

LNA-LVVA, 7349-1-73, Izejošo rakstu kopiju žurnāls, 1701.

LNA-LVVA, 7349-1-150, Karal̦a Kārḷa XII vēstules, 1701.

LNA-LVVA, 7349-1-320, Vidzemes guberṇas igauṇu ekonomiskā apgabala pārvaldnieka K. G. Štromfelda raksti.

LNA-LVVA, 7349-1-321, Vidzemes guberṇas igauṇu ekonomiskā apgabala pārvaldnieka K. G. Štromfelda raksti.

LNA-LVVA, 7349-1-338, Kara komisariāta lietas.

\section{PUBLICĒTIE AVOTI}

Karolinska krigares dagböcker jämte andra samtida skrifter (1903). II. Lund: Gleerup, 125 s. 


\section{RAKSTI PERIODIKĀ}

Jakovḷeva, M., 2003. Cīna par varu Kurzemes hercogistē pēc hercoga Frīdriha Kazimira nāves (1699. g. aprīlis - 1701. g. janvāris). Latvijas Vēstures Institūta Žurnāls, 1, 65-96.

Jakovleva, M., 2007. Karadarbība Kurzemes hercogistē un Lietuvas pierobežā Lielā Ziemeḷu kara sākumā (1700. g. februāris - 1703. g. maijs). Latvijas Vēstures Institūta žurnāls, 2, 42-72.

\section{LITERATŨRA}

Dunsdorfs, E., 1962. Latvijas vēsture 1600-1710. Stokholma: Daugava.

Höglund, L. E., Sallnäs, ̊̊., 2000. Stora nordiska kriget 1700-1721: fanor och uniformer. Karlstad: Acedia press.

Kohs Jumītis, A., 2018. Zem Kārḷa XII karogiem. Latviešu karavīi 18. gadsimta Zviedrijas armijā. Rīga: Zvaigzne ABC.

Laidre, M., 1996. Segern vid Narva: Början till en stormakts fall. Överstättning Enel Melberg. Stockholm: Natur och Kultur.

Palli, H., 1966. Mezhdu dvumja bojami za Narvu. Jestonia v pervye gody Severnoj vojny. Tallin: Akademiia nauk Estonskoi SSR Institut istorii.

Wimmer, J., 1956. Wojsko Rzeczypospolitej w dobie wojny pótnocnej (1700-1717). Warszawa: Wydawnictwo Ministerstwa Obrony Narodowej. 


\title{
PROVISION OF SWEDISH ARMY IN LIVLAND AT THE END OF 1700 AND THE FIRST HALF OF 1701
}

\section{MIKUS ŽAGATA}

Mg. hist.

E-mail:

\begin{abstract}
Article describes the way local administration of Vidzeme (Livland) and central administration of the Kingdom of Sweden managed supply of goods and provisions needed for functioning of the Swedish army units that were stationed in the province in the late 1700 and the first half of the 1701. Research shows that maintenance of Swedish army units during this period was complicated and negatively affected the overall economics of the province. That, in turn, brings forward a question regarding extent of devastation brought about by several Russian military plunder incursions in the province during the second half of the 1701 and 1702 about which general field marshal Boris Sheremetev greatly boasted to Peter I in a letter.
\end{abstract}

Keywords: Great Northern War, Erik Dahlberg, Charles XII, Swedish Livonia.

\section{SUMMARY}

The article is dedicated to the approach used by local administration of Vidzeme (Livland) and central administration of the Kingdom of Sweden to manage supplying goods and provisions needed for the functioning of the main Swedish army units that were stationed in the province during the end of the 1700 and the first half of the 1701. The author studied archive materials of Swedish governor-general of Vidzeme that hitherto have not been extensively researched in Latvia. Thus, the author managed to reconstruct the way how supplying of army with goods was organised and to define the issues that had to be tackled in order to do that.

During the fall of 1700 until the battle of Narva, issues with supply of resources arose mostly in the enemy-plundered southern (Latvian) part of Vidzeme. However, soon after the battle of Narva, issues regarding provision of army with supplies arose also in the northern (Estonian) part of Vidzeme which was spared from enemy plunders. In addition, Russian 
military units started to pillage eastern parts of Vidzeme starting from late 1700. In order to ensure the supply of the required resources, local administration ordered that all the resources (apart from those that had to be left for the inhabitants' own use and seeds) from government-owned manor estates were to be delivered to army warehouses. In order toreinforce it, king Charles XII prohibited the delivery of resources from countryside to towns. That, in turn, led to issues with provision of garrison at least in Riga, where raw materials for brewing of beer were no longer available. Despite the fact that governor-general of Vidzeme managed to fill up countryside warehouses intended to support the march of king's army to Riga, he had to admit that he could not do the same for Riga. Thus, Charles XII ordered to bring additional supplies to Riga from Tallin and Pernau. The fact that the administration of Vidzeme had to raise and maintain extra military units (Estonian and Latvian home guard and other units) after the departure of the main Swedish army from Vidzeme in July 1701, paints a grave picture of economic situation in Vidzeme. That, in turn, brings forward a question regarding the extent of devastation incurred by several Russian military plunder incursions in the province during the second half of the 1701 and 1702, about which general field marshal Boris Sheremetev greatly boasted to Peter I in a letter. 


\title{
ONLINE CONFERENCE
}

\section{Scholarly Readings of Young Historians VI: Turning Points in the History of the Baltic Sea Region: People, Ideas, Events}

Valmiera Museum, November 27-28, 2020

\section{Jauno vēsturnieku VI zinātniskie lasījumi Pagrieziena punkti Baltijas jūras regiona vēsturē: cilvēki, idejas, notikumi}

\author{
2020. gada 27.-28. novembris, Valmieras muzejā
}

\author{
Piektdiena, 27. novembris \\ (Friday, November 27)
}

\begin{abstract}
Opening ceremony
9:00 Brief welcome by Ričards Gailums - deputy mayor, deputy chair of Valmiera City Council Brief welcome by Guntis Zemìtis - senior researcher at the Institute of Latvian History, UL, principal investigator of the National Research Programme project No. VPP-IZM-2018/1-0018
\end{abstract}

Session I Archaeology, Prehistoric Ages and Middle Ages

9:15-9:30 Mārcis Kalniņš, PhD candidate, University of Latvia. The Stone Age Habitation Around Lake Burtnieks: New Discoveries and Research Perspectives

9:30-9:45 Vanda Visocka, PhD student, University of Latvia; Mārcis Kalniņš, PhD candidate, University of Latvia. Surveying and Researching Clay Beds in the Context of Archaeological Pottery Studies: A Case Study of Lake Burtnieks, Lower Reaches of River Daugava and Western Courland

9:45-10:00 Freydis Ehrlich, PhD student, Institute of History and Archaeology, University of Tartu. The Arrival of Chicken in the Baltics - when, how, and why?

10:00-10:15 Margarita Novikova, Mg. hist., Political Aspects of Introducing Religious Reforms in Livonia: An Overview of Discussions (1549-1554) 
10:15-10:30 Discussion

10:30-11:00 Recess

Session II History of the $19^{\text {th }}$ and $20^{\text {th }}$ Century

11:00-11:15 Evaldas Vilkončius, PhD student, Vytautas Magnus University. Evolution of the Hospital Architecture During the Interwar Lithuania: The Influence of Modernism

11:15-11:30 Anastasija Smirnova, PhD student, University of Latvia. Similarities and Differences of Incorporation and Development of Urban Elberfeld Social Care System in Baltics (late $19^{\text {th }}$ century-1940): Case of Riga

11:30-11:45 Mariya Oinas, PhD student, University of Tartu. Peasant Migration in Russia as a Type of Transit Migration (on the example of migration of Estonians to Kazakhstan)

11:45-12:00 Nijolè Vailionytè, PhD student, Vytautas Magnus University. The Attitude Towards Childlessness in Magazine "Moteris" (1920-1940)

12:00-12:15 Karina Račaitytè, PhD student, Vytautas Magnus University. The Identity of Kaunas Inhabitants: The Memories of Three Generations

12:15-12:30 Discussion

12:30-14:00 Recess (Lunch / coffee)

III sesija Viduslaiki un Jaunie laiki

14.00-14.15 Elīza Dāldere, Bc. hist., LU maǵistrante. Garīdzniecība kā aktors Austrumbaltijas eiropeizācijas procesā (1199-1229)

14.15-14.30 Justīne Fišere, Mg. hist., Rīgas vēstures un kuǵnniecības muzejs, LU doktorante. Rīgas Mazās ǵildes cunftu pārkāpumu un sodu antropologija, 14. gadsimta otrā puse - 17. gadsimta sākums: šrāgu tekstu piemērs

14.30-14.45 Vitālijs Varnakovs, Bc. hist., Latvijas Universitāte. Ivana IV mērkii Baltijā Livonijas kara laikā

14.45-15.00 Mikus Žagata, Mg. hist. Zviedru karaspēka apgāde Vidzemē 1700. g. nogalē un 1701. g. sākumā

15.00-15.15 Gints Skutāns, $M g$. hist. Jauni argumenti Beverīnas jautājuma risinājumam

15.15 Pirmās dienas noslēguma diskusija 
Sestdiena, 28. novembris

(Saturday, November 28)

10.00 Konferences otrās dienas atklāšana. Alberts Rokpelnis, Valmieras muzejs

I sesija Latvijas vēstures jautājumi: 20. gs. pirmā puse

10.15-10.30 Guna Plakane, Mg. hist., Latvijas Universitāte, doktorante. Latvijas Komunistiskās partijas satelītorganizācijas 1920. gados: Rīgas Arodbiedrību centrālbiroja piemērs

10.30-10.45 Inna Gīle, Mg. hist., LU Latvijas vēstures institūts, doktora grāda pretendente. Cēsu karavīru sanatorijas loma karavīru veselības uzlabošanā, 1929-1940

10.45-11.00 Ginta Ieva Bikše, Mg. hist., Latvijas Universitātes Latvijas vēstures institūts, LU doktorante. Spānijas pilsoṇu kara (1936-1939) dalībnieks: vācbaltietis, "viltus princis" Harijs Domela

11.00-11.15 Reinis Ratnieks, Mg. hist., LU doktorants. Nacionālo partizānu cinnas Valmieras apriņ̧īi (1944-1955): atspogulojums Latvijas PSR periodikā

11.15-11.30 Aleksandrs Petrovs, Mg. hist., LNA Latvijas Valsts arhīvs. Padomju Latvijas rūpniecības atjaunošana un attīstība XX gs. 40.-50. gados: būvmateriālu ražošanas nozares piemērs

11.30-11.45 Diskusija

11.30-11.45 Pārtraukums

II sesija Latvijas vēstures jautājumi: 20. gs. otrā puse un 21. gs. sākums

12.00-12.15 Kaspars Strods, Mg. hist., Daugavpils Universitāte, doktorants. Sarežğitais pagātnes mantojums: ieskats Otrā pasaules kara piemiñas vietās Rēzeknē (1945-1991)

12.15-12.30 Jānis Goldšmits, Bc. hist., LU maǵistrants, Latvijas Okupācijas muzejs. Čekas šautuves izpēte "Stūra mājā"

12.30-12.45 Kārlis Fogelis, Bc. hist., Latvijas Etnogrāfiskais brīvdabas muzejs, Latvijas Universitātes maǵistrants. Pokainu svētvietas fenomens, tās veidošanās vēsture un arheolog̣iskās liecības 
12.45-13.00 Gundega Skagale, Bc. hist., LU maǵistrante, Dobeles Novadpētniecības muzejs. Dzemdētāju akmeṇi. Vai tikai 20. gs. beigu fenomens?

13.00-13.15 Viesturs Rasnacis, $M g$. hist., Latvijas Kara muzejs. Ieskats Latvijas un Igaunijas Republikas robežjautājumos pēc Valmieras zonālajā valsts arhīvā esošajiem dokumentiem (1993-1995)

13.15-13.30 Noslēguma diskusija

Konferenci organizē (Conference organising committee):

Dr. hist. Guntis Zemitis, Institute of Latvian History, UL

PhD Rasa Račiūnaitè-Paužuolienė, Vytautas Magnus University

PhD Laurynas Kurila, Lithuanian Institute of History

PhD Mati Laur, University of Tartu

Dr. hist. Ilze Boldāne-Zeḷenkova, Institute of Latvian History, UL

Dr. hist. Anita Čerpinska, National Archives of Latvia

Dr. hist. Eva Eihmane, Institute of Latvian History, UL

Dr. hist. Uldis Neiburgs, Institute of Latvian History, UL

PhD Kristine Beķere, Institute of Latvian History, UL

Mg. hist. Alberts Rokpelnis, Valmiera Museum 
Jauno vēsturnieku zinātniskie lasījumi VI The Scholarly Readings of Young Historians VI

Izdevējs: LU Akadēmiskais apgāds www.apgads.lu.lv 